\title{
Tangut Contracts
}

Contracts are the legal records of bilateral or multilateral agreements on transactions, mortgage, leases, and loans, according to the spirit and formality of laws. Therefore, contracts are private documents that specify the rights and profits, status and obligations, and the legal relationships between persons in society. It is generally the case that in ancient China, contracts dominated the sphere of private law, hence the dual track of laws as captured in the saying, "Political (public) laws to the government, private contracts to the populace." It is also true that throughout the dynastic eras of ancient China, the vast number of legal documents were produced and popularised in the economically advanced areas of the Central Plains, especially in the Han Chinese commercial communities. By contrast, the ethnic regimes and ethnic-minority areas in the medieval period have left sparse and scattered records of private contracts. Even rarer are manuscripts of legal documents written in ethnic-minority languages.

The imperial law code of Western Xia, the Laws of Heavenly Prosperity, not only recognises the juridical force of privately-signed contracts but also requires that all especially important contracts, such as the records of large-scale land, livestock, and human sales, be approved with the red stamp of the government's Bureau of Transaction Tax. Such a requirement speaks to the solemnity of contract-signing as a legal ritual in the Tangut Empire.

The corpus of Tangut contracts, therefore, offers a realistic lens through which scholars are now able to reflect on the commerce, transactions, and concrete economic activities that took place under Tangut rule. These contracts, themselves invaluable manuscripts, constitute a critical and indispensable primary source on Tangut society and economy.

Each of the contracts comes with a meticulous documentation of time, personalities, events, and scenarios, which form a distinct narrative of a historical story. Looking closely into these sources, it is no longer impossible to imagine the vivid scenes of the Tanguts borrowing and lending, buying and mortgaging, selling and employing, and at times pledging mutual support. The rich historical data in the contracts enable us to restore the plots and settings of the Tanguts transacting amongst themselves in villages, towns, and cities. For these reasons, the discovery and survey of Tangut contracts make great progress in the historical research of Tangut economy, deepening our inquiry into the foundation of Tangut society. 
Amongst the manuscripts excavated in Khara-Khoto, Tangut contracts are by far the most numerous and diverse, with a total of more than 150 registered numbers and about 400 pieces of contracts. They also constitute the largest portion of all contracts dated to the Tang and Song period (including the corpus of contracts found in the Dunhuang cave).

\subsection{Types}

Not unlike other medieval legal documents, Tangut contracts in the Russsian collection of Khara-Khto manuscripts are relatively easy to identify, thanks to the evidence of prints and signatures as required by legal formality. Not all social documents with the print (of finger-length) or with the label of a name, however, are necessarily contracts. One exception is the genre of 'military document' unique to the Tangut textual tradition, which also conventionally ends with similar prints and signatures but obviously does not fall into the category of private legal contracts. From a different perspective, the literal identification and statistical compilation of Tangut contract is, after all, far from a simple task. Only a small fraction of Tangut contracts was written and preserved on a single page of paper for the exclusive purpose of legal documentation. Far more frequently, the content of the contract was scribed on a manuscript-roll fragment, or even a broken piece of paper. It oftentimes happens that even the prints and signatures are lost, when the main paper loosens from its certain parts. Many other contracts were written on the back pages of books, usually Buddhist sutras. Sometimes, a fragmented manuscript roll contains multiple different contracts. However, based on available statistics, manuscripts that contain contracts within exceed the number of 200 registers, and given that some texts include more than one contract, the total number of different contracts reach up to more than 400 pieces, on a wide spectrum of preservation-quality.

\subsubsection{Loan Contracts}

Most loan contracts are in fact accounts of grain loan, which total a number of more than 110 registers and 320 items, indeed the largest in quantity and in diversity of all Tangut documents. In terms of materiality, some are long scrolls while others are book volumes, single pages, and fragmented pieces. There are quite a number of single-page contracts complete in content and rich in information; others are scrolls that contain anywhere between four or five to eight or ten documents, and sometimes even more. The largest single register is the Инв. No. 4696-6, "Grain loan account in the Shen Year of Guangding," $288 \mathrm{~cm}$ 
in length and with a total of 24 distinct contracts in 190 lines of Tangut text. At the same time, legal documents tend to be as short as a single line, when, for example, the amount of grain loaned was quite small. There are, in addition, one contract of loan-repayment and two others of monetary loans.

\subsubsection{Transaction Contracts}

Transaction contracts documented the legal exchanges of land, livestock, and human beings. Amongst the 13 pieces of land sale contracts, some are single pages and with damages, but overall, they remain thorough and well-preserved. Livestock sales have been identified in more than 20 documents, whereas contracts of human transactions are much rarer, with only three pieces discovered thus far. A long scroll of contracts, the Инв. No. 5124, contains 23 contracts dated to late first or second months in the Yin Year of Tianqing (1194), ranging from land sales (eight items), land leases, livestock transactions, employments, and grain loans. Because most of the Tangut transaction contracts involve agreements on foreclosure, the trading volume is usually quite large, and the texts of the contracts are complex and comprehensive.

\subsubsection{Lease Contracts}

Contracts of both land-lease and livestock-lease have been excavated in Khara-Khoto. There are three registers and eight pieces of such lease contracts. In both Dunhuang and Turfan social documents, farming lands on lease is referred to as 'to till a land rented from the landlord' (Chinese: 夏田 or 佃 田). Land leases are therefore called “contracts of land rent" (Chinese: 夏田 券, 夏田契 or 佃田契). ${ }^{1}$ Khara-Khoto leases refer to the cultivation of rented land as 帊 [phio], which derives phonetically from the Chinese character 包 [pau], the character for "charter," "farmland rent," and "to place a lease under contract."

Besides, there are eight registers and 14 pieces of grain-loan and livestockmortgage contracts. There are several other contracts whereby the exchange of

1 Han, Guopan. "Cong Tulufan Chutu Wenshu zhong Xiatian Quanqi lai Tan Gaochang Zudian de Jige Wenti” [從吐魯番出土文書中夏田券契來談高昌租佃的幾個問題]: "A Discussion on Several Issues about Tenancy in Gaochang, based on Farmland Lease Contracts in the Unearthed Turfan Documents" Han, Guopan (eds.). Dunhuang Tulufan Chutu Jingji Wenshu Yanjiu [敦煌吐魯番出土經濟文書研究]: Studies on the Economic Documents Excavated in Turfan and Dunhuang. Xiamen: Xiamen University Press, 1986, pp. 199-224; Yang, Jiping. "Qushi Gaochang yu Tangdai Xizhou Shazhou Zudianzhi Yanjiu" [䴴氏高昌與唐代西州沙洲租佃制研究]: “A Study of Land Lease Contracts in Gaochang of the Qu Family, and Xizhou and Shazhou of Tang Dynasty" in Han, 1986, pp. 225-292. 
livestocks is guaranteed under the condition that it is to be supplemented by an additional form of compensation.

\subsubsection{Employment Contracts}

Legal documents of employment include contracts of either labour or livestock employment. Only one piece of labour contract, an extremely rare and precious find, has been identified. One other contract, however, is a labour mortgage' deed, whereby the signer of the contract willingly conveyed his labour to the creditor as security on a loan. The numerous livestock-employment contracts were signed, more often than not, when a household had already sold its livestock but had to secure a loan of the same animals from the current owner who purchased them. There are, besides two items of grain-loans, livestock-employment and land-mortgage contracts.

\subsubsection{Communal Contracts}

Communal contracts are statements of rules and requirements of civilian societies. Only two such documents have survived to date, both of which are Tangut-era contracts of social groups founded by the pledge of 'mutual support' of inducted members. They add new materials to 12th-13th century sources on Chinese social communities, which demonstrate the existence of self-organised communal organisations at the bottom of the civil society in Western Xia.

Other contracts are more difficult to identify and categorise due to higher levels of damage and the paucity of eligible traces of words in the texts. In some cases, contracts are preliminarily identified as official documentation of either loans or transactions, but information on the goods concerned are either missing or unclear.

An additional batch of contracts has been found in the pile of Tangut manuscripts which Sir Marc Aurel Stein seized from Kara-Khoto and stored in the British Library. Amongst the smaller number of Tangut texts that remain at the National Library of China, a few manuscripts have also been identified as contracts. Archeologists in Gansu and Inner Mongolia in recent years have made new discoveries of contracts in the midst of other documents. Especially worth noting is a particular piece of Tangut loan document found in a hoard of Tangut materials in Chanshan village, Wuwei, Gansu in the $198 \mathrm{os.}^{2}$ Of course,

2 Sun, Shouling. “Xixia Qianding Shennian Dianmi Qiyue” [西夏乾定申年典麻契約]: “Proso Millet Loan Contract in the Shen Year of Qianding in Western Xia" in Zhongguo Wenwu Bao [中國文物報]: China Cultural Relics News, issue 5, 1993 . 
contracts dated to Western Xia written in Chinese characters are also of great value and have been the subject of fruitful research in recent years.

\section{$1.2 \quad$ Formats}

Tangut contracts are often written on slightly yellowish white hemp papers. With a contract that was fully written out on one piece of paper, the manuscript is usually $20 \mathrm{~cm} \times 30 \mathrm{~cm}$. The Инв. No. 5227 "Contract of Grain loan on mortgage in the Chou Year of Tianqing," $19.3 \mathrm{~cm} \times 30.5 \mathrm{~cm}$, is about exactly this size; others are slightly narrower in length, such as the $18.7 \mathrm{~cm} \times 13.4 \mathrm{~cm}$ Инв. No. 2996-3, а contract of livestock mortgage. A considerable number of Tangut contracts appear in clusters, with multiple documents written on the same piece of paper. It often happens that one long scroll contains dozens of contracts at the same time, which form a chain of legal documents that looks like a series of accounts. One example is the $19.5 \mathrm{~cm} \times 15^{2} \mathrm{~cm}$ Russian manuscript-scroll Инв. No. 4596, "Account of grain loans in the Chou Year of Guangding" with eight contracts; the Инв. No. 4696 "Account of grain loans in the Shen Year of Guangding" is broken into a few segments that patched together form a long scroll as long as $500 \mathrm{~cm}$ and with more than $5^{\circ}$ contracts. Despite the large quantity, contracts such as these are usually written on papers of lower quality and are subject to further damage and deterioration at the fronts and ends.

Each contract begins with an unindented line, always written in ink and mostly rendered in cursive, though occasionally in the running or standard script. The Contract Parties follow a relatively set format, which starts with the exact time of the contract, including the reign era, jiazi (the period of sixty years in the sexagenary cycle), year, month, and day. Usually under the character for 'day' (date, the temporal unit) 纹 [djij], there may be found a smaller Tangut character for 'day' (as in daylight, as opposed to night) 妙 [nji_]. It is only in particular contexts that the complete indication of time may be abbreviated. For example, where there is already a specific reference to a certain year, the Contract Party may only sign "Yin Year" or names of other years that only include the "Earthly Branches." When, of course, a contract immediately follows a preceding one, a "same day" (ibid.) suffices. After the year and date of the contract come naturally the identities of the Contract Parties themselves, which are referred to in Tangut as the 爱唚瓶㢁 [.jwi-r dźiow wji mjijr] lit. "text/document, plea/plaint, conduct/compose, person/party" i.e. "the Contract Parties who compose the documents." This is then followed by the main content of the contract - the terms, conditions, and agreements of loans and transactions. Information such as quantities, prices, interests, payments, and compensations are recorded in great detail. As a rule, the contract 
also clearly lays out the forms and amounts of penalties in the sorry case of default. The Contract Parties have to make clear of their consent, typically in the expression that their "heart willingly submits" to the terms. In the last and usually indented line, the Contract Parties sign their own names and print the

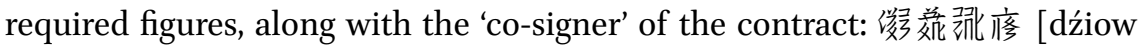
dźjwi- sa mjijr] lit. "plea/plaint, reciprocal/additional, link/associate, person/ party" i.e. "the party associated with the contract." A separate line or space is reserved for the same formality of the witness: 版较 [nwə dzjwo] lit. "know, person" i.e. "the person who bears witness to this transaction." With the names and prints of the signing parties indented, these final lines usually align with the main text at the bottom. Sometimes, the types and quantities of goods traded or loaned are labelled again, either in words or notations, above the Contract Parties' signatures.

The more important ones of the unearthed documents, especially the large-volume foreclosure contracts, are stamped in red by the Bureau of Transaction Tax. The rectangle-shaped red stamp is large in size, supported from below by the shape of a lotus flower and decorated from above with the figure of lotus leaves. On the top of the stamp is a line of four Tangut characters, which read from right to left, 跤叛䊽能 [phə źji. zji.j io.] lit. "price, market, tax, office" i.e. "The Bureau of Transaction Tax." Contracts with such a red stamp were approved by the government. Those who paid transaction taxes were entitled to the so-called 'red contracts.'

A considerable number of Tangut contracts, however, are short in length and simple in content. These are records of small and non-foreclosure loans or transactions, such as borrowing a small quantity of grains. Some of these legal documents feature no more than one line, which notes the name of the borrower, the amount of the loan, the promised repayment, and the signatures of other relevant parties.

Communal contracts are a distinct category of Tangut legal documents. Such contracts begin with a prolegomenon-like general statement, the indication of time, day, and year, followed by the rules and regulations of the 謊

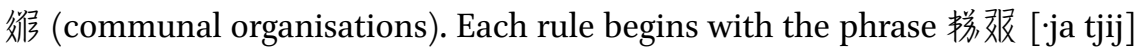
lit. "one, item/chapter/order" i.e. "the one item of rule." The common activity of the community is referred to in the rules as 维琂 [ljwu dzji-.], lit. "meeting/ alliance, gather/congregate" and members of the community are 蔪茫 [tha ·ji], lit. "large many/majority" i.e. the greater public, the many, or the masses. The contracts end with the signatures and prints of all constituent members.

Overall, it may be said that Tangut contracts inherited the format and formalities of Chinese traditions in the Central Plains. Contracts in Western Xia contain all of the most basic elements of traditional contracts in this era, but 
they also exhibit special features, either in content or in terminology, that are unique to Tangut economic culture.

\section{Loan Contracts}

The largest number of Tangut contracts are loan records, with accounts of grain loans as the majority. Lending and loaning grains is an economic activity that took place at a massive scale and on a frequent basis at the bottom level of Tangut society. And although it is only food concerned, such loans in fact concern many aspects of Tangut society.

Among the social documents discovered in Dunhuang, about 70 pieces are grain loan contracts, commonly referred to by scholars as "wheat loan contracts" or "millet loan contracts." ${ }^{3}$ The significantly larger corpus of Khara-Khoto grain loan contracts are several times the quantity of Dunhuang documents. Indeed, Western Xia is by far identified as the dynasty with the greatest number of survived contracts prior to Ming and Qing.

In the past, scholarship on Tangut contracts was sparse and limited. About 15 remnant pawn and mortgage contracts have been studied and published by Chen Guocan. ${ }^{4}$ Towards the end of 1980 s, a batch of Tangut archives and artifacts were discovered in the Chanshan village, which is located in the rural outskirts of Wuwei city of Gansu province. Among the discoveries, one piece of Tangut grain loan contract has been interpreted and introduced by Sun Shouling. ${ }^{5}$

\subsection{Grain Loans}

\subsubsection{Rules and Institutions for Making Grain Loan Contracts}

The Tangut Laws of Heavenly Prosperity incorporates the rules on lending and loaning into the imperial law code, especially the 15 items of legislation in Book III on "pressing and requesting debt and interest" which provide a concentrated and comprehensive set of regulations on debt. Indeed, the fact that a separate section in the imperial dynastic law is devoted to the question of debt shows the level of attention that the Tangut bureaucracy paid to the protection

3 Tang, Geng'ou; Lu, Hongji (eds.). Dunhuang Shehui Jingji Wenxian Zhenji Shilu [敦煌社會 經濟文獻真跡釋錄]: An Interpretive Transcription of the Original Dunhuang Economic Documents (hereafter Dunhuang Economic Documents). Beijing: National Library of China, Quanguo Tushuguan Wenxian Suowei Fuzhi Zhongxin [全國圖書館文獻縮微複製中心], 1990, pp. 76-147.

4 Chen Guocan, 1980, pp. 143-15o.

5 Sun Shouling, 1993. 
of the creditors' proper rights. It also reveals the government's stance on using written and codified laws as an instrument to press the poor to yield to the debt solicitations of the wealthy.

The following are specific regulations concerning the establishment and sanctions of contracts, according to legislations on the solicitation of debt in the Laws of Heavenly Prosperity:

Individuals who sell or purchase, lend or loan, or conduct a variety of other businesses that involve multiple parties, who thus voluntarily associate with one another, may establish a written document, on which are written the relevant words that indicate the prices of purchase, the amounts of money, the contexts of equal measurement, as well as single and collective numbers, all of which the public and private transactors are supposed to command in clear language on the written document. In case of any parting regretting or defaulting on the contract in the future, penalties under official terms are to be delivered in the government, whereas under private names, to private individuals. Those who change their pledge, who enjoy an official title, are penalised with the confiscation of a horse; those who change their heart, who are commoners in status, are sentenced to 13 lashes. ${ }^{6}$

Tangut laws promoted the use of "written records" - or contracts- to document loans, transactions, and other civil affairs, in order to protect the interests and rights of the creditors. They also regulated and normalised economic affairs in the private social space of civil life, thus avoiding potential escalations and proliferations of civil disputes into larger causes of social unrests. Moreover, the laws set specific requirements on the main content of the contracts and penalise those who breached them. Penalties in the form of cash, grains, and properties were sometimes turned over to the government, and other times to the private individuals who own the debt.

Once again, the discovery of such a large amount of Khara-Khoto loan contracts suggests that the enforcement of Tangut laws on the making of contracts extended to the peripheral territories of Western Xia, such as the rural areas of Khara-Khoto near the northwestern borders of the empire.

Most of the known Tangut loan contracts were documented in clusters of several documents on single pages. Some long scrolls contain several dozens of contracts, which are connected in serial accounts of contracts. In most cases of such long scrolls, although the borrowers appear to be different, the

6 Revised Laws of Heavenly Prosperity 3, "Urging the Repayment of Interests," pp. 189-19o. 
creditors are sometimes the same. These turn out to be accounts kept by a single creditor, whose lending contracts with multiple debtors were compiled together for the sake of convenience. The aforementioned Инв. No. 4696 is such an account of more than 5 o grain loan contracts patched together into a long scroll.

Contracts were not only records of proof and evidence but also documents of legal force that occupied a critical role in the socio-economic lives of individuals and communities. A Tangut grain loan account was, therefore, both a written agreement that facilitated the making of loans and transactions as well as a proper contract with all its legal force and implications.

\subsection{2}

Categories, Translations and Interpretations of Grain Loan Accounts

Although most of the grain loan accounts found in Khara-Khoto were bound as long scrolls of multiple contracts, rather than single-page documents, many contracts of land, livestock, and human transactions (including animal loans) were in fact recorded on single pages. In most cases, single-page contracts were used in larger transactions of valuable goods. By contrast, the serial accounts of grain loans were devoted to regular lendings of common commodities, which were conveniently written or kept together.

There is a great variety of Tangut grain loan accounts. For a fuller understanding of the diverse formats and contents of Tangut grain loan contracts, below is a selected list of translated Tangut contracts of various degrees of simplicity and complexity:

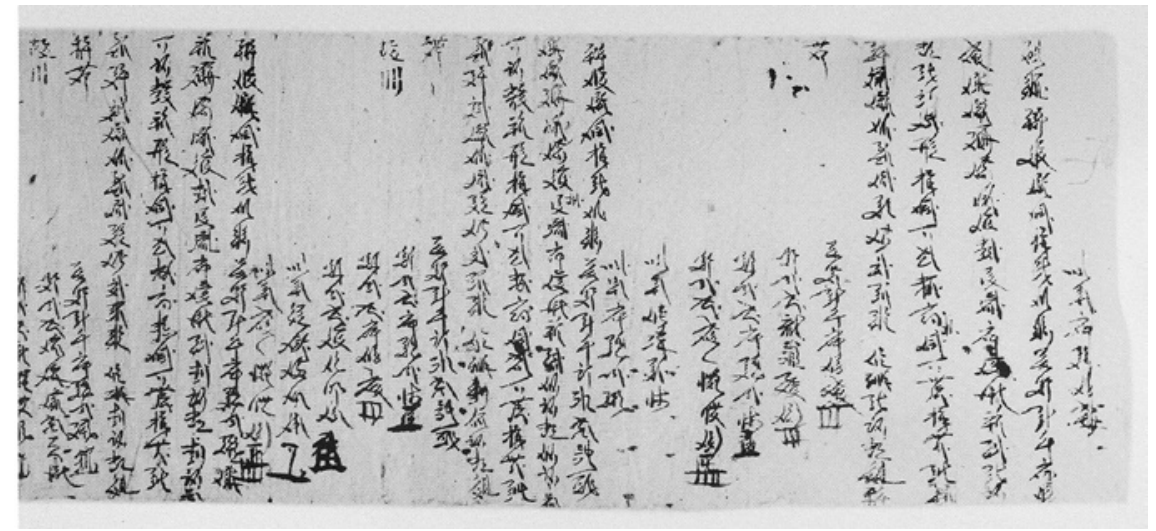

FIGURE 117

Инв. No. 4762-6(1) (front of manuscript): Yin year of Tianqing (1194) grain loan account 
1. Инв. No. 4762-6(1) Yin Year of Tianqing (1194): serial account of multiple grain loan contracts, a $20.6 \times 5^{2} \mathrm{~cm}$ handwritten manuscript on hemp-paper scroll, with 31 lines in Tangut cursive. ${ }^{7}$

Translation: ${ }^{8}$

Yin Year of Tianqing, 29th Day of 1st Month, Contract Party9 篻父䊅 [ [ jow mjijr]

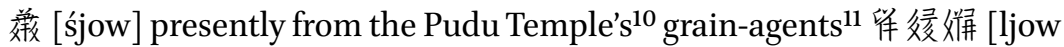
lja mja $]^{12}$ et al. loans ${ }^{13} 10$ dan

of wheat, 10 dan of barley; since the first day of February, 1 dou 2 sheng of interest per month,

Repaid till capital and interest are equal; overdue fines by official law ${ }^{14}$ is 10 dan of wheat, willingly agreed.

Contract Party 众㒸举 [mjijr śjow] (stamp)

Co-Contract Party ${ }^{15}$ son, 曚臀徐 [parya ne_w $]^{16}$ (stamp)

Co-Contract Party 篟效微怑 [ljow phə tśhja śia ] (stamp)

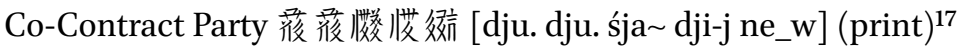

7 TN: see Russian Collection of Khara-Khoto Manuscripts, vol. 13, 279-280. Numbers in smaller fonts reflect the order of the contracts in the long scroll. In the main text of the translation, I have used brackets, (1), (2) ... instead of circles, (1), (2)... as in the Chinese edition.

8 The first line is left off from the previous contract, and is therefore left untranslated.

9 The borrowing party in a Tangut contract is known as 'the one who sets up the contract':

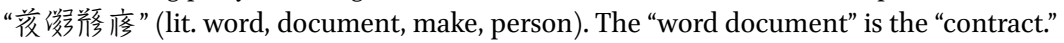
To "make" is to do, to set up, and to establish.

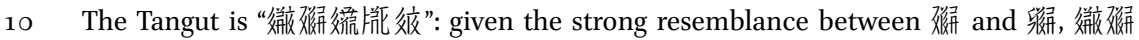

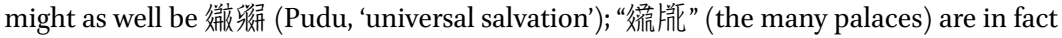
"the many temples." “腋” [tśjow] also means 'temple.' This temple is commonly translated as "Pudu Temple," one of the Buddhist temples in Khara-Khoto in the Tangut period.

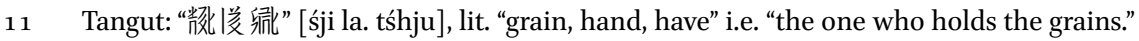
These are persons in charge of managing the grains in the temples.

12 TN: Liang Lama is the primary agent in charge of handling the properties of the Pudu Temple, an asset manager who takes care of loans, sales, and leases.

13 Tangut: “形” [lhjwi], lit. "to take," here "to borrow."

14 Tangut: “㣪傩” [kow bju], lit. "office/government, accord" i.e. "according to the government authority." This is a way of saying "according to the laws and regulations established by the political authority."

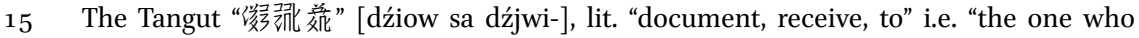
receives the contract." In most cases, it refers to a co-Contract Party, who agrees to take over the financial liability in case the principle Contract Party can no longer fulfil the terms therein. The co-contractors are in most cases the family relatives or close friends of the main Contract Party.

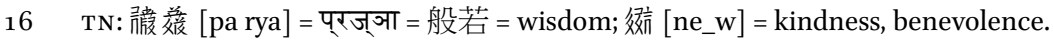

17 TN: the smaller-font character $\square$ on the side is purposefully neglected in order to render a sensible name. 
Witness ${ }^{18}$ 继结敚㴹 [phjij śjo wa śia ] (stamp)

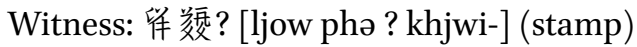

2. Инв. No. 6377-16(1) in the Mao Year of Guangding (1219), handwritten manuscript of Grain loan account on a $20.6 \times 53.7$ hemp-paper fragment, with 28 lines of writings in the Tangut cursive. ${ }^{19}$

Translation:

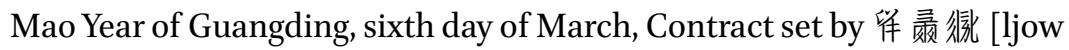
śja lhji.]

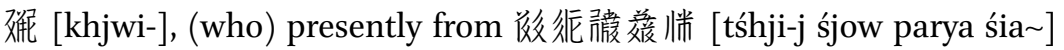
the owner of capital ${ }^{20}$ Laofangshi's place, loans

1 dan 5 dou of wheat, with an interest of 5 dou per dan loaned, which in total amount to 2

dan 2 dou 5 sheng, with the due date being the first day of August in the same year

(at which time the debtor) should come with amount of grains prepared. After that date, there will be a charge of 2 dan (penalty fee) per dan of loan.

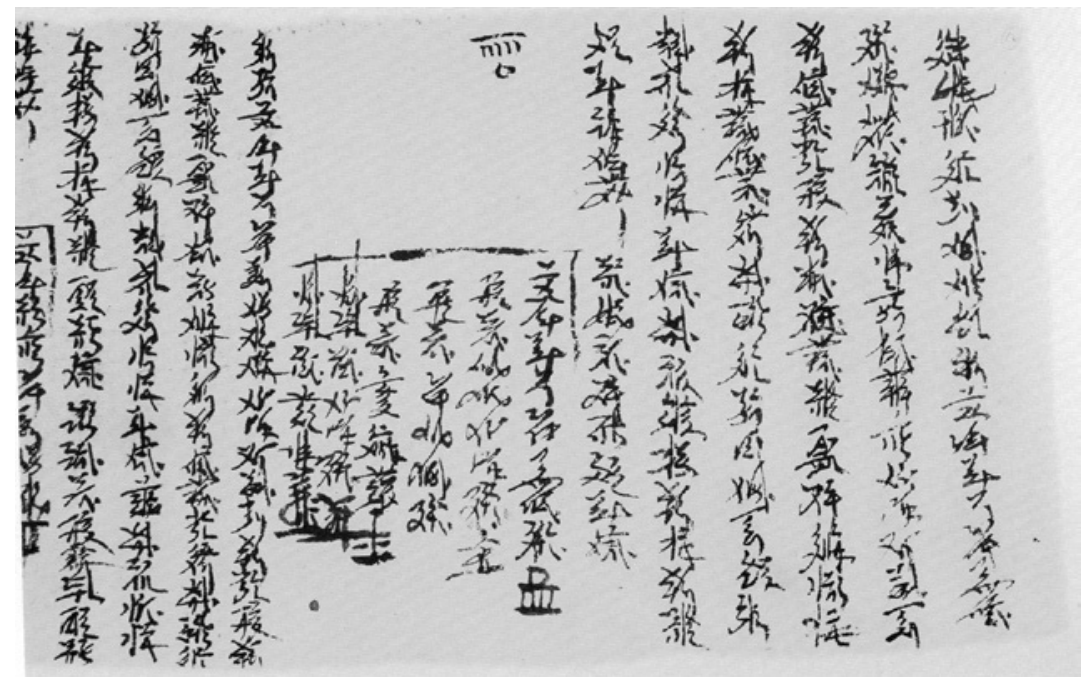

FIGURE 118 Инв. No. 6377-16: Mao year of Guangding (1219) grain loan account

18 Tangut: “版评交” [nwə dzjwo], lit. "the person who knows," is translated into "witness" throughout this book.

19 Russian Collection of Khara-Khoto Manuscripts 14, pp. 145-146.

20 Tangut: “托韸廖” [tśhji zow mjijr], lit. "principle-holder," i.e. the creditor who legally owns the loan. 
Willing: the amount recorded on the document ${ }^{21}$ is to be repaid.

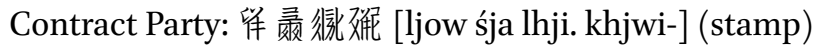

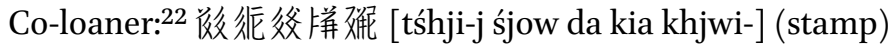

Co-loaner: 留侟很佌 [ljow gji-_lhji. khjwi-]

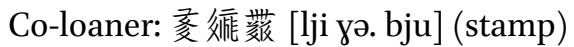

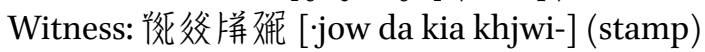

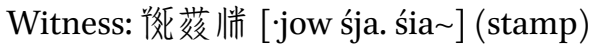

The two manuscripts above are fairly standard examples of Tangut loan contracts. Grain loan accounts of the same type include the Инв. No. 7741, 4762$6-7,5870$, and $8005 .{ }^{23}$ It seems that in format, Tangut contracts were for the most part similar to documents used by the Han Chinese populations in the Central Plains, especially with respect to the key information covered: the date when the contract was signed, the name(s) of the main 'Contract Party' (here it refers to the borrower or debtor), the name of the lender or creditor, the types and quantities of the grain loan, the time limit of the loan and due dates of repayment, the interest rate, and finally the overdue penalty fees in case of default. The document ends with the signatures and prints of the witnesses.

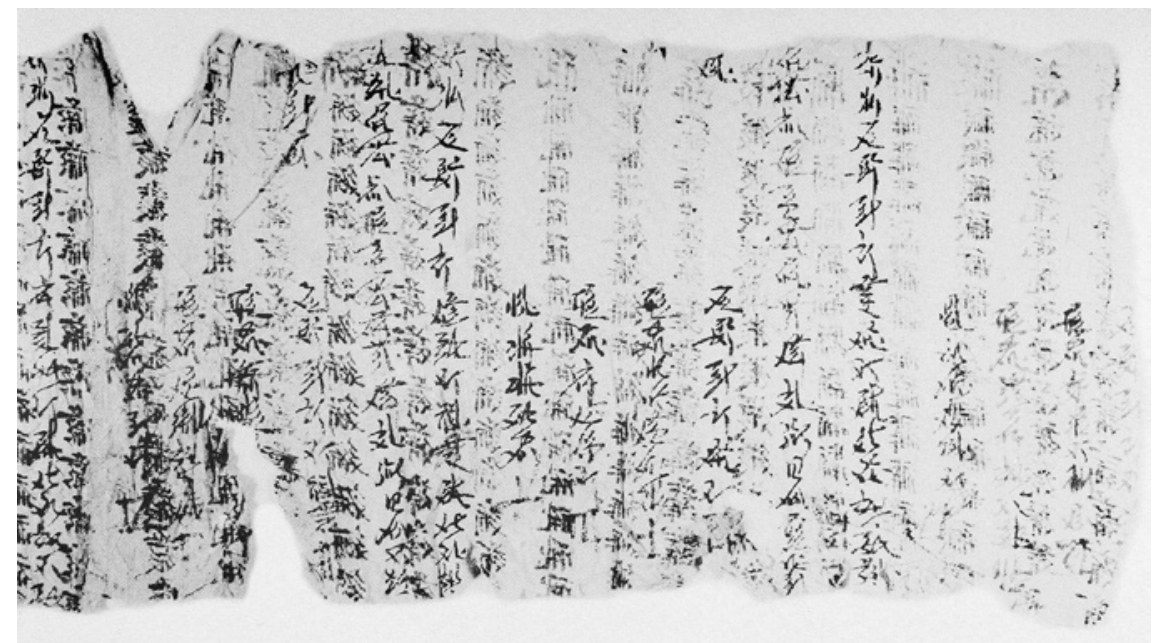

FIGURE 119 Инв. No. 4526: Serial account of grain loans

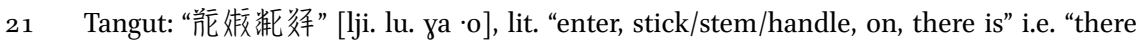
are [recorded/found] on the document."

22 Tangut: “形落” [lhjwi dźjwi-], lit. “borrow, with” i.e. co-borrower.

23 Russian Collection of Khara-Khoto Manuscripts 14, pp. 188-191; 13, pp. 279-280; 14, pp. 57-61; 14, pp. $250-252$.
} 
3. Инв. No. $45^{26}$ (2) serial accounts of five grain loans, handwritten on an $18.6 \times$ $65 \mathrm{~cm}$ hemp-paper remnant manuscript, with 27 lines of Tangut in the cursive. ${ }^{24}$ This piece of manuscript continues as the end of the previous contract. Lines 4-9 are translated as follows:

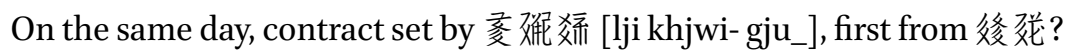
[zjwi. $\cdot 0$ ? wejr] borrows 5 dan of assorted grains, which is turned into ${ }^{25} 7$ dan 5 sheng, due on the first day of August, to be repaid.

Contract set by 鹤㸚 [khjwi- gju_] (stamp)

To borrow $\square \square \square \square \square$ (stamp)

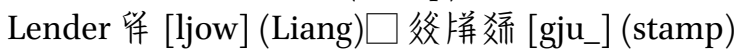

Witness: ${ }^{26}$ Hun 垪硛爰 [kə ta śjow] (print)

Although there are six lines in this contract, the main content concerning the terms of the agreements is written out in only two lines plus one character with key information including the date, identities of the Contract Party (debtor) and lender (creditor), the amount of grain loaned, interest rate, and the terms of repayment. Although the penalty fees seem to have been omitted, the contract does end with the signatures and prints of the Contract Party and the witness.

4. Инв. No. 7892-7 account of grain loans, handwritten on a $20.7 \times 21.4 \mathrm{~cm}$ hemp-paperremnantmanuscript with 15 lines of Tangutwritingsin thecursive. ${ }^{27}$ The contracts contained in this manuscript are even simpler legal records of loans, as short as three or two lines.

The content of the first three contracts is translated as follows:

One person named Liang?? and his son 舦嗳 [dźjij wejr], et al., borrow 5 sheng of wheat; amounts to 1 dou. (calculative notation) 5 sheng of wheat, borrower Liang??

Co-borrower, son (of Liang) 航并爱

One person, a shijun named 曜鍰 [khjwi- wejr], borrows 5 dou of wheat; amounts to 1 dan.

Borrower: 唃鍰 [khjwi- wejr $]$

\footnotetext{
24 Russian Collection of Khara-Khoto Manuscripts 13, pp. 217-218.

25 Tangut: “僢” [we], "to become," "to turn into."

26 Tangut: “版” [nwə], "to know," "the one who knows," i.e. witness.

27 Russian Collection of Khara-Khoto Manuscripts 14, p. 206.
} 


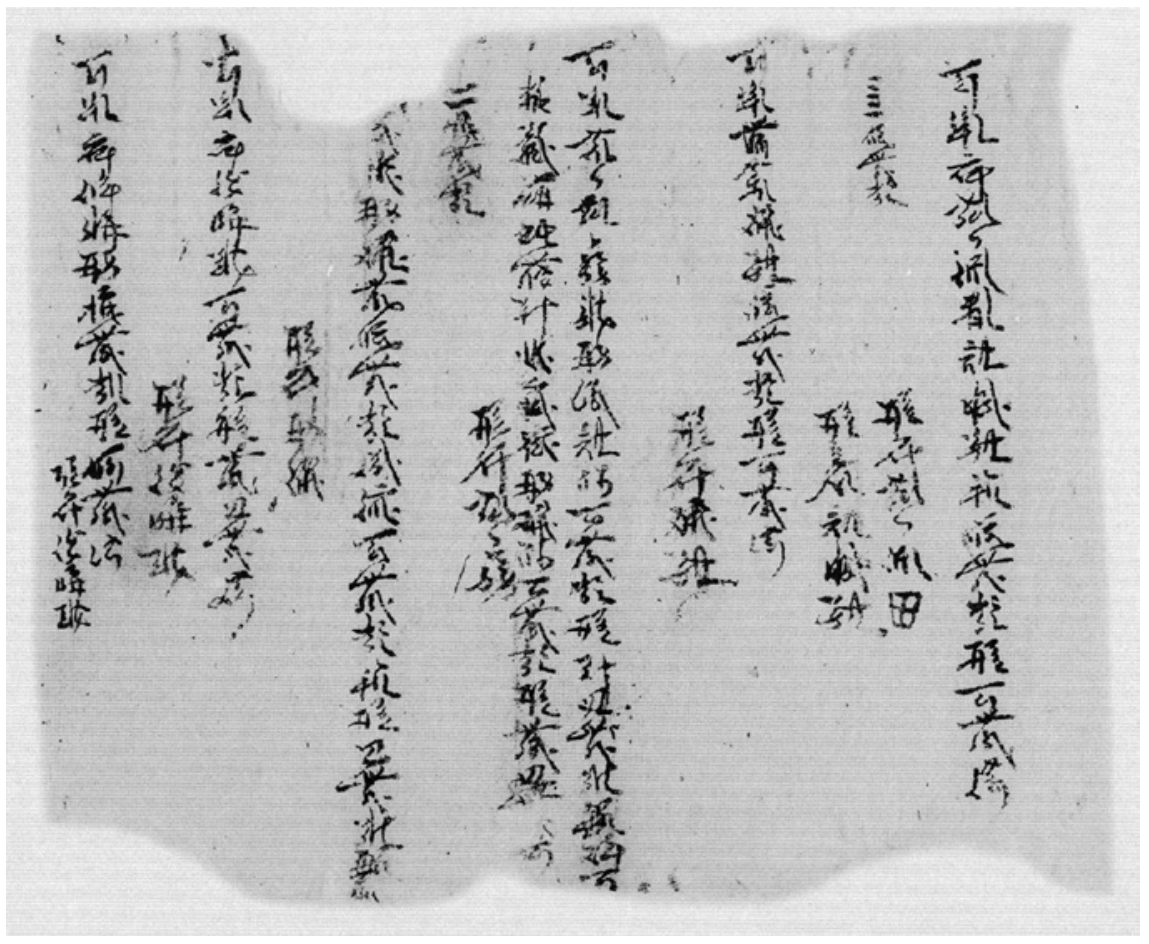

FIGURE 120 Инв. No. 7892-7: Account of grain loan contracts

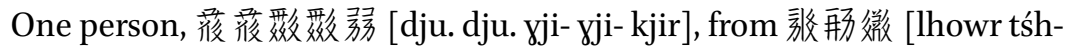
jwor bie_j] borrows 1 dou of wheat; interest of more than 8 sheng, 1 sword is now mortgaged as security; then from Qingluo borrows 1 dou of wheat; turns into 1 dou 8 sheng.

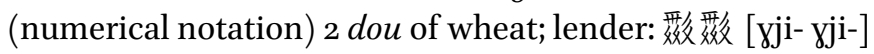

Despite the simplicity of the two documents above, neither actually lacks the key information of a contract. The first piece contains three lines, including the name of the Contract Party and the co-borrower, the amount of grain to be loaned, interest rate, and the names of both the lender and the witness, followed by their prints. The only elements missing are the date and terms of penalties in case of default. The second contract is even simpler: two lines in total, the 'main text' is compressed into only one line, which nonetheless provides the name of the Contract Party, the types and amounts of grains loaned, and the amount of capital and interest. Usually, the smaller the amount loaned, the simpler the contract is. In these two cases, the first contract involves a mere 5 sheng of wheat, and the slightly more capacious deal in the second contract concerns only 5 dou of wheat. 


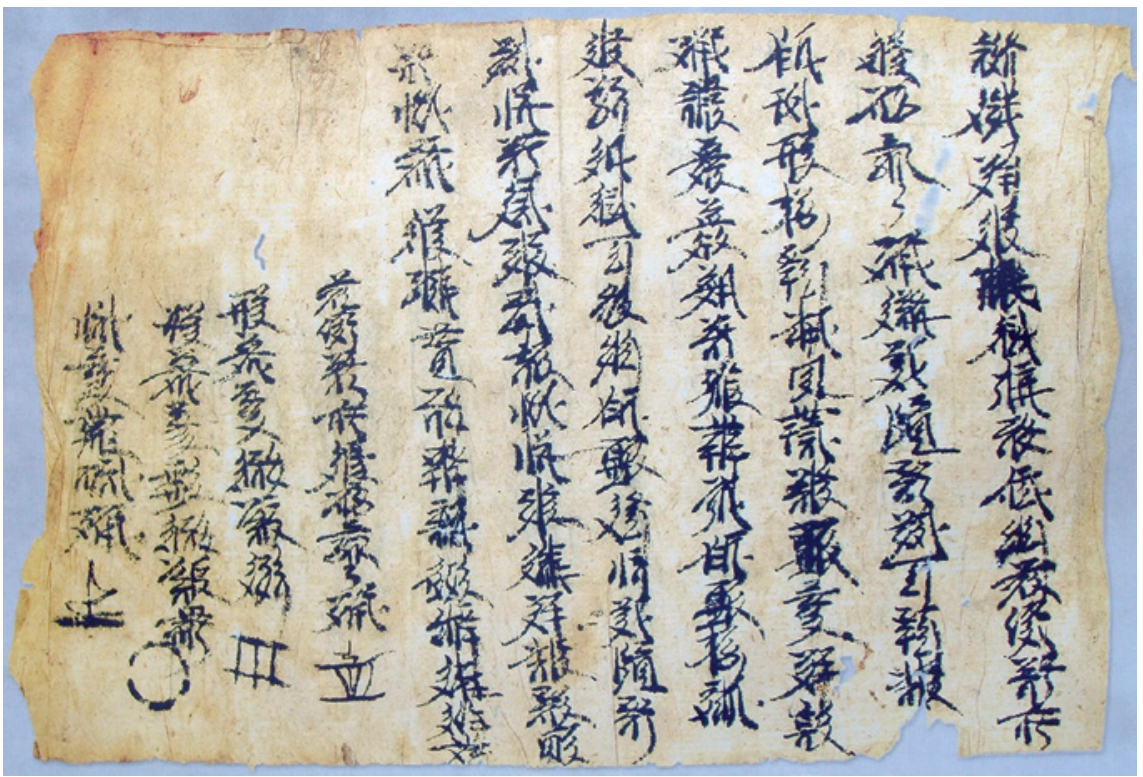

FIGURE 121 Wuwei G31.004 [6728]: Shen year of Qianding (1224) grain loan contract

5. Wuwei G31.004 [6728] Shen Year of Qianding Reign (1224) grain loan account, handwritten on an $18 \times 27 \mathrm{~cm}$ white (with light yellowish taints) hemp-paper manuscript, with 11 lines of Tangut writings in the cursive. ${ }^{28}$ It is a complete, detailed, and rare single-page grain loan.

Translation:

Shen Year of Qianding Reign, 25th day of February, contract set by

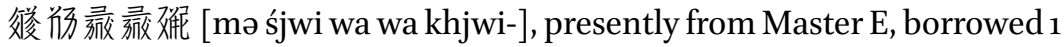
dan of millet (capital), at the interest rate of 8 dou per $d a n,{ }^{29}$ arranged to be

retrieved from 澱茒爰 [parya śjow]. The combined loan and interest are to be

prepared by the 1st day of September in the same year, and repaid to master E

in case ${ }^{30}$ the sum is not paid after the due date, besides the payment of the millet,

28 Chinese Collection of Tangut Manuscripts 16, p. 389.

29 Some erasing, etc. seems to have been applied to the original Tangut character for "interest"; below is the character for the Tangut surname "Li."

30 The original character is “哮” [tjij], "quality," "rank," etc. By its position, and by comparative analysis with other contracts, it is possibly intended to be “㞼” [tiij], meaning "if." 
there will be a penalty fee of 70 guan of cash according to the official law; (each's) own ${ }^{31}$ heart is willing.

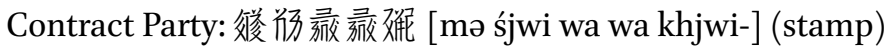

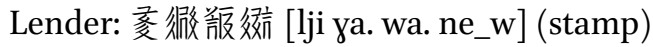

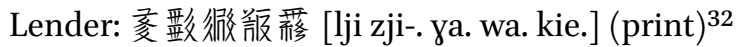

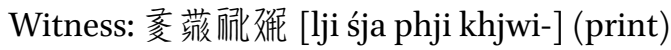

The total of more than 250 characters in this contract introduces the precise date (era-title, earthly branch, month, and day), names of the Contract Party and lenders, types of grains loaned, interest rate, the due date of repayment, where to retrieve and to whom to repay, and the terms of penalty fees, concluded with the signatures and prints of all contracting parties and the witness. The grains loaned thereby is not a large sum, but the content of the contract is comprehensive and rendered in a standardised format. It may therefore be treated as a classic example of Tangut grain loan accounts.

The Institute of Cultural Relics and Archaeology in Inner Mongolia houses an additional piece of Khara-Khoto grain loan account. Registered as M21.003[ $\mathrm{F}_{355}: \mathrm{W}_{75} / 2 \mathrm{O} 26$ ], the $27 \times 20 \mathrm{~cm}$ wheat-loan contract manuscript is dated to Year Yihai (1215?). ${ }^{33}$ It is similar in format to regular grain loan accounts, with the exception of a notation added to the contract at the end of

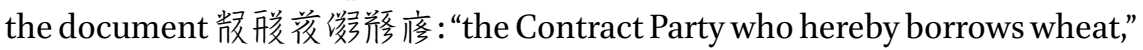
a title which specifies the nature and type of borrowing behaviour involved in the legal-commercial relationship.

\subsubsection{Time of the Contract}

Each Tangut grain loan contract begins by indicating the time when the agreement is reached and the document signed. The better-preserved contracts provide extensive details with respect to time: the title of era and reign, the sexagenary cycle, the calendar year, month, and day. Most contracts provide not only the time when the contract officially went into legal force but also the time when the agreement was expected to be fulfilled. Needless to say, this is

The two characters are close in resemblance. The first character is the bottom part of the second.

31 The original character is “燐” [-jij]: surname. Given its position, and by comparative analysis in the light of parallel formats in similar contracts, it is possibly a miswritten “倩” [mər], meaning "principle." The two characters look similar, since their right parts are almost identical.

The stamp here is a circle, unlikely to have been hand-drawn, but rather the print of an object with a circle-shaped cross-section. This type of stamping is quite rare, and probably one of the primitive and preliminary forms of stamping in the modern sense. 
especially the case when the interests were calculated based on the temporal duration of the loan.

Despite the large quantity of Tangut grain loan contracts, they tend to come from the latest 50 years of the Western Xia dynasty. One of the earliest manuscripts, the Инв. No. 4079, for example, is dated to "Ren-chen Year of Qianyou Reign" (information on month and day missing), which was the Third Year of Qianyou (1172) under the reign of the Renzong Emperor of Xia, Weiming Renxiao. Инв. No. 157 is dated to "(Qian)you, Xu year, day 12 of May," a formulation that refers to the 'earthly branch' only but omits the 'heavenly stem.' Given that Renzong emperor Qianyou's reign lasted for 24 years, there were not one but two Xu years in between: the Wuxu, ninth year of Qianyou (1178), and the Gengxu, twenty-first Year of Qianyou (119o). The first Xu year was perhaps the more likely, for the simple thought that had it been the second Xu year, when the Contract Parties would have had more reason to specify the complete 'stem and branch' in order to differentiate this date from the first. Another example is the Инв. No. 5949-28, ${ }^{34}$ which mentions its date as "Qianyou, Zi year, twenty-fifth day of the tenth month." But it soon becomes clear that there were also two Zi years within the Qianyou era: the Gengzi, eleventh Year of Qianyou (1180), and the Renzi, twenty-third year of Qianyou (1192). For the same reason, it may be speculated that the first $\mathrm{Zi}$ year was slightly more likely than the second.

A certain number of loan contracts are simple in their recording, or are, in fact, incomplete manuscripts. It requires some rigorous analysis to ascertain the time of such documents. For example, Инв. No. 5949-22 contains four pieces of contracts, none of which provides information on date or time. The third piece mentions "the first day of leap-year March in the Mao Year." Based on this evidence, an investigation into all possible instances of "March in the leap-year of Mao" in Tangut history points to the lone possibility: the Jimao ninth year of Guangding (1219). Scholars may then date not only this one contract, in particular, but also the other three pieces recorded in the same manuscript to the same year. Likewise, although the five contracts contained in the Инв. No. 5949-27 are without precise dates, given the reference to "the second day of the leap-year March in the same year," it is possible to also date these five documents to 1219 .

It is difficult to date contracts which only document the 'earthly-branches' but not the 'heavenly stems,' especially when there were two identical earthlybranch years within the same reign era. In some cases, however, rigorous 
textual scholarship may overcome the challenge of incomplete information. For example, the Инв. No. 5949-18 reads, "Wei Year of Guangding, day 29 of the third month." Within the Guangding era of Western Xia, however, there were thirteen years (1211-1223), long enough to encompass two Wei years, namely the Xinwei first year of Guangding (1211) and the Guiwei thirteenth year of Guangding (1223). It should be noted, however, that the Shenzong emperor Zunxu forced Xiangzong emperor Anquan out of the throne in the seventh month of the Xinwei year, which was then renamed the first year of Guangding. ${ }^{35}$ Therefore, since there was not yet a proper reign of Guangding in the previous sixth months of the Xinwei year, it is safe to conclude that this contract signed in "The Third Month, in the Wei Year of Guangding" is from the second Wei year, namely the Guiwei thirteenth year of Guangding (1223). And once this time is established, it is now possible to date the two other contracts from the same page to the same year of 1223 .

As mentioned above, the vast majority of Tangut grain loan accounts surviving to this day are dated to the late period of Western Xia. Even Renzong-era manuscripts are quite rare, by comparison to the more numerous examples of documents from the time of Huanzong and Shenzong. The largest number of these contracts were signed during the reign of Huanzong's Tianqing and Shenzong's Guangding years. In fact, Huanzong emperor Weiming Chunyou enjoyed only one reign-era in the name of Tianqing, which lasted for 12 years (1194-1205). Likewise, the only reign-era under the rule of Shenzong emperor Weiming Zunxu was the span of 13 years known as Guangding (1211-1224). Below are some of the contracts that mention the eras of Tianqing and Guangding in their main texts:

- Jiayin Year of Tianqing (1194): Инв. No. 3586, 4384-7, 4762-6, 5870, 7741

- Mao Year of Tianqing (1195): Инв. No. 4696-1

- Wei Year of Tianqing (1199): Инв. No. 7892-3

- Guihai Year of Tianqing (1203): Инв. No. 7889, 7892-4, 7892-5

- Jiazi Year of Tianqing (1204): Инв. No. 4978-1

- Chou Year of Tianqing (1205): Инв. No. 5227, 7910-3

- Wei Year of Guangding (1211): Инв. No. 5949-18

- Shen Year of Guangding (1212): Инв. No. 4696-2, 4696-3, 4696-4, 4696-5, 4696-6, 4696-7, ${ }^{36} 5949-19-21$

- Chou Year of Guangding (1217): Инв. No. 4596

- Wuyin year of Guangding (1218): Инв. No. 8оо5-1, 8о05-2

35 History of Song, Bk. 486, "Western Xia” Part II.

36 Russian Collection of Khara-Khoto Manuscripts 13, pp. 237-247. The title "Grain Loan Contract in the Shen year of Guangding" in Инв. No. 4696-6 has been confused with the "Account of Alcohol Prices" in Инв. No. 4696-8. 


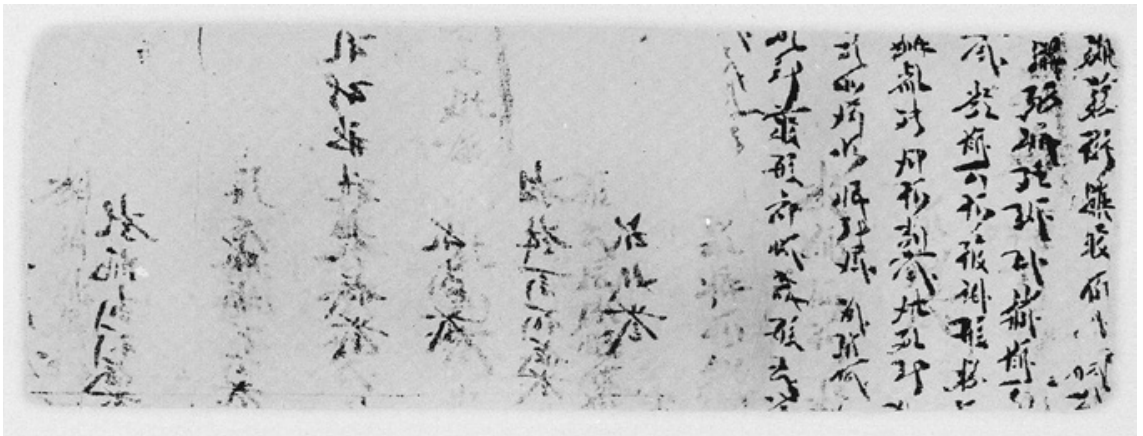

FIGURE 122 Инв. No. 3586: Jiayin First Year of Tianqing (1194) Account of grain loan fragment

- Mao Year of Guangding (1219): Инв. No. 5949-22, 6377-16

- Gengchen and Si Year of Guangding (1220, 1221): Инв. No. 986-1

- Si Year of Guangding (1221): Инв. No. 2955, 5949-23

- Wu Year of Guangding (1222): Инв. No. 4783-6, 5147-1, 5147-2, 5147-3, 5147-4, 5949-23, 6377-17

- Wei Year of Guangding (1223): Инв. No. 5223-3, 5949-18, 7893-5

The latest existing Tangut contract is dated to the Wei Year of Guangding (1223), a mere space of four years before the fall of the Tangut Empire and only two years before the Mongol army captured the city of Khara-Khoto.

If information such as the date and time of a given contract is referred to in previous contracts within the same batch, the Contract Parties customarily omitted a few words in order to avoid redundancy. If, for example, the contract was signed in the same year but in different months and days, then the signing parties had the option to omit the precise year and sexagenary cycle, thus simply noting down "same year, $\mathrm{x}$ month $\mathrm{x}$ day." If the contract was written both in the same month and in the same year, then the signatories would typically shorten it to "same month, $\mathrm{x}$ day." If multiple contracts were signed into effect on the exact same date, most would simply write, "same day." For this reason, there sometimes existed a series of contracts that begin with the same reference: "same day," suggesting that multiple parties took out grain loans at the same location, probably from the same creditor. One could imagine the many visitations by an endless stream of borrowers at the doorsteps of the rich, and the scene of multiple debtors going to and from, lining up, lingering, and departing the site. The omission or abbreviation of references to date and time has its pros and cons. It lends more convenience, but once the string of contracts is damaged, resulting in the loss of previous contracts, then there would be no way to ascertain the precise time as listed in a given contract. 


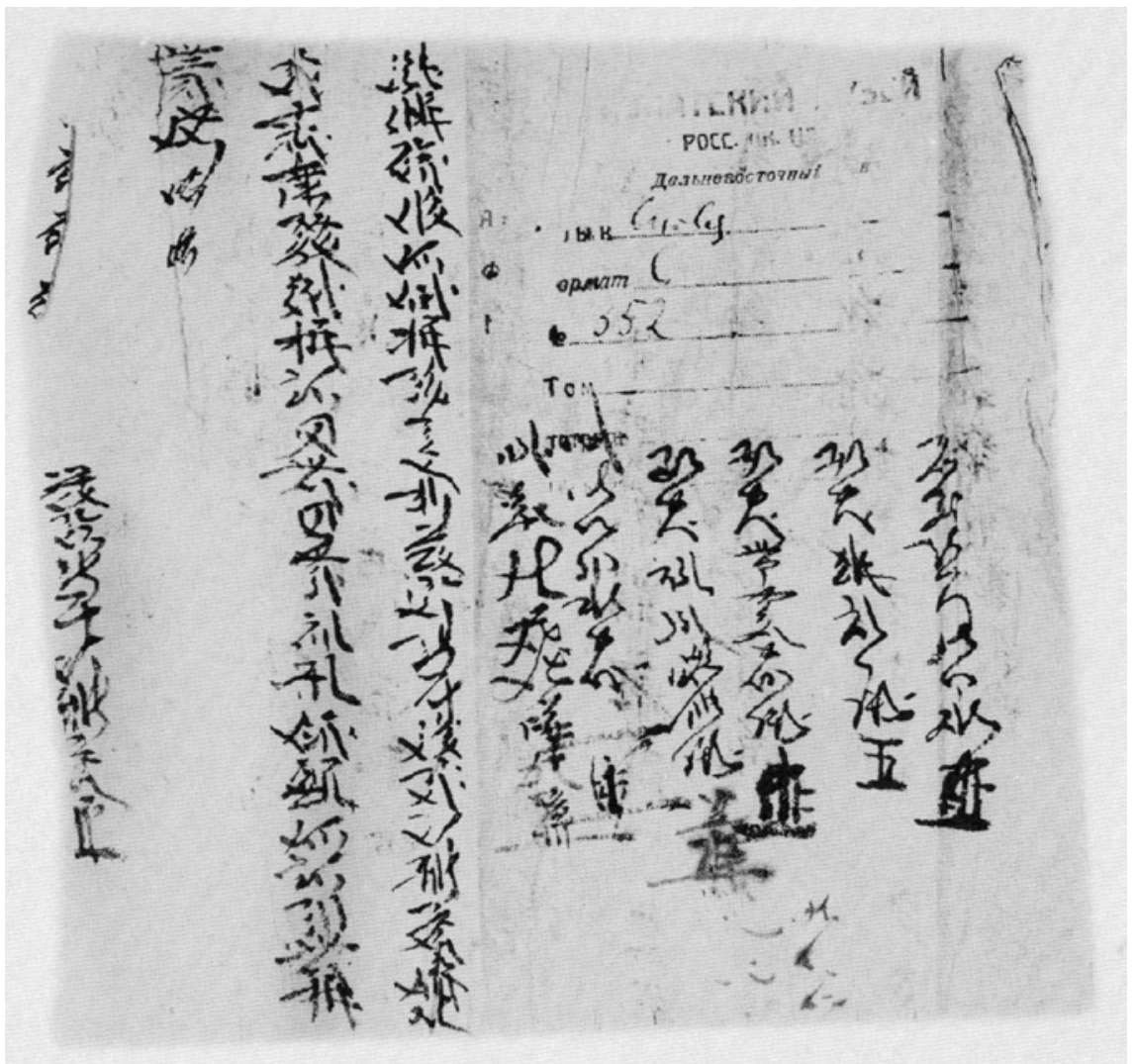

FIGURE 123 Инв. No. 5223-3: Wei Year of Guangding (1223) Account of grain loan fragment Note: TN: Not manuscript 3586.

Occasionally, however, contracts that come later may fill in some badly needed information. In general, the Tanguts take out grain loans in the spring and the summer. Thanks to the higher altitude of Khara-Khoto and the cooler temperature of its continental climate, the Tanguts here sowed in the spring and harvested in the autumn. The interlude between spring and autumn was the time of shortage in supply, depletions in the granary, and lack of income. Whilst some loan contracts were signed in the last month of the previous year, at the earliest, most were negotiated from the second to the fifth month of the year.

\subsubsection{The Identity of the Borrowers}

In the Tangut tradition, the contracting parties in a financial loan or transaction were referred to as "the ones who set up the document," i.e. the signatories to a legal contract. In a monetary loan contract written in Chinese 
characters, in the Khara-Khoto document Инв. No. 7779A from the Fifteenth year of Tiansheng, a signatory by the name of Langna refers to himself as "the one who sets up the words." It is safe to assume that "the one who sets up the document" and "the one who set up the words" are interchangeable and customary translations.

In the technical legal language of Tangut grain loan accounts and contracts, "the one who sets up the document" refers to the party which initiates the contractual transaction, i.e. the Tangut poor who actively sought to take out a loan to alleviate hunger and poverty, the lack of seeds for the sowing season, and literally the dearth of foodstuff for subsistence. The names of these contract-initiators appear twice in a standard contract. The borrower's name first appears at the beginning of the contract, immediately after the time of the contract. Then again, it is featured a second time at the end of the contract, below the main content of the document and where the borrower signed his or her own name, in addition to a stamp. At the second appearance of the debtor's name, it was acceptable, if not customary, to omit the family name.

Although most of the documented debtors were Dangxiang Tanguts, the overall demographics of Tangut borrowers were anything but homogeneous. In fact, the Khara-Khoto economic records exhibit a robust ethnic heterogeneity. As the majority ethnicity in Western Xia, the Dangxiang Tanguts refered to themselves as 䫰很 (Minyak), or Fan (番) in Chinese. Most Tangut family names were bisyllabic 'compound surnames. ${ }^{37} \mathrm{~A}$ large number of Tangut borrowers were identified by their names in the contracts: Zhiyi in Инв. No. 40796(2); Mingni in Инв. No. 4384-7(2); Mingbu in Инв. No. 4762-6(2); Qiluo in Инв. No. 5147-1(1);38 Jili in Инв. No. 5870(1); Pingshang in Инв. No. 5870(13); Weili in Инв. No. 587о(16); Хiyu in Инв. No. 5870(17); Yерu in Инв. No. 5949-27(2); Yehe Инв. No. 5949-28(2); Luopu in Инв. No. 5949-23(1); Weiyi in Инв. No. 7741-1(3); Jili "The Benevolent Dog" in Инв. No. 7741-2(1); Guding in Инв. No. 8о05/1(2), etc. The "Moshui" that appears in the Wuwei loan contract G31.004[6728] is also a Dangxiang Tangut name.

37 Russian Collection of Khara-Khoto Manuscripts 6, pp. 137-138; 10, pp. 39-69; Shi Jinbo, 1989; Nie, Hongyin; Shi, Jinbo. “Xixiawen Sancai Zazi Kao” [西夏文三才雜字考]: “A Study of the Assorted Characters of the Three Realms" in Zhongyang Minzu Daxue Xuebao [中 央民族大學學報]: Bulletin of the Minzu University of China, issue 6, 1995, pp. 81-88; Li, Fanwen, and Nakajima, Motoki, "Computational Analysis of Tangut Literature Zazi," Research Institute for Languages and Cultures of Asia and Africa (ILCAA) at the Tokyo University of Foreign Studies, 1997, pp. 82-83 and 117-125.

38 Russian Collection of Khara-Khoto Manuscripts 14, p. 22. Only a part of the image, Инв. No. 5147-1 "Grain Loan Contract in the Wu Year of Guangding" is printed in that collection. A full image is supplied here. 


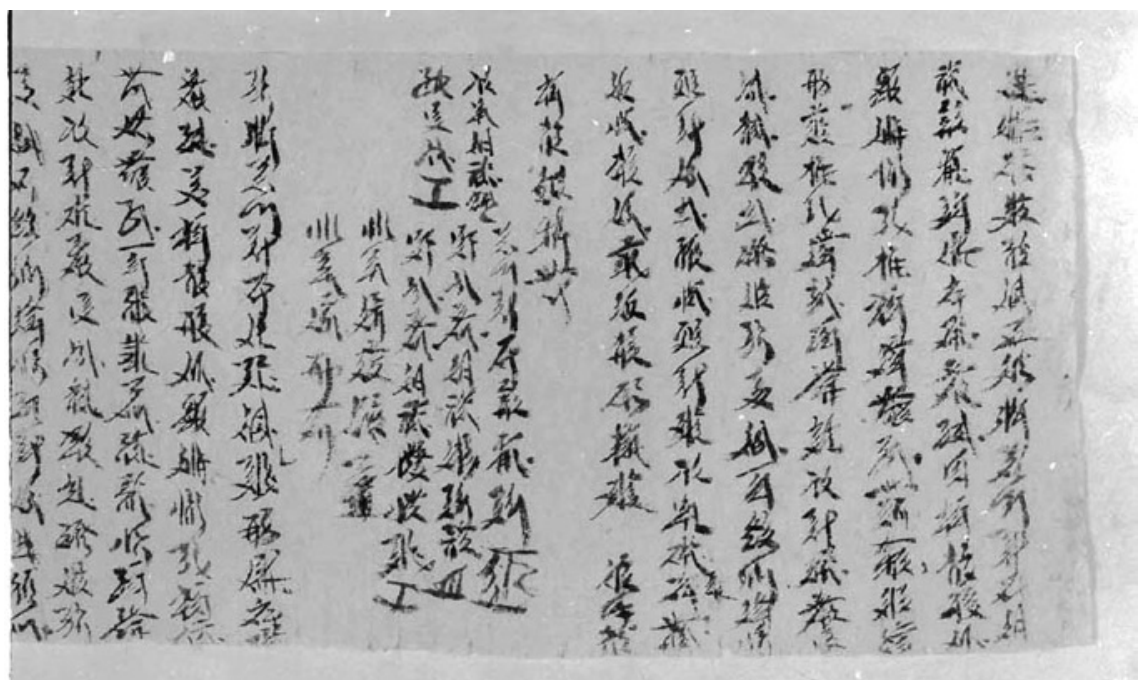

FIGURE 124 Инв. No. 5147-1: Wu year of Guangding (1222) account of grain loan

Some borrowers are easily identified as Han Chinese: Li Baiji in Инв. No. 4526(2); Yang "Qianqianquan" in Инв. No. 4696-3(2); Caо Suzhou in Инв. No. 4696-3-5; Wu Xianling in Инв. No. 582о(1); Hun "Shiyuesheng" in Инв. No. 5949-18(1); Luo "Wuyuebao" in Инв. No. 6377-2о(2); Xu Wujin in Инв. No. 7893-2oV, etc. Li, Yang, Cao, Wu, Hun, and Luo are all Han Chinese surnames. Certainly, the area that came under Tangut domination was inhabited by Han Chinese prior to the migration of the Dangxiang Tanguts. Throughout the imperial era of Western Xia, large Han Chinese populations subsisted on Tangut territories and for the most part engaged in agriculture. Some Han Chinese even held government offices. Both the Tangut and the Chinese editions of the Assorted Words, edited and published in Western Xia, feature long lists of Fan and Han surnames. The only difference lies in the order; whereas the Tangut Assorted Words places Fan names before Han names, the Chinese edition reverses that order. It is also evident and curious from the examples above that, under Tangut cultural influences, some Chinese parents resorted to multiple-character given names, beyond the convention of adhering to one or two characters. Qianqianquan (謙謙犬), Nazhengma (那征麻) and Wuyuebao (五月寶) are Chinese names given in the Tangut style. Typical Tangut given names include "The force of Helan [mountains]," "The Fortunate Mountain," "The Joy of the River," and so forth.

It often happens that both Fan and Han names appear across several contracts within the same batch of documents. The fact that ethnic Tanguts and the Han Chinese loaned from the same creditor shows that the ethnic groups 
dwelled in the same area, and even cohabited the same communities and neighbourhoods. The contracts, therefore, offer one more testimony to the tight and interlinked socio-economic exchanges between the Fan and Han populations.

The name of a borrower in the contract Инв. No. 7741-3(2) appears to be

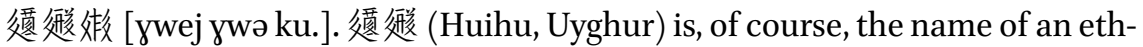
nic group. A sizeable population of the Huihus lived in Western Xia, whilst others were close neighbours of the Tanguts. In the Tangut Assorted Characters, Huihu is also listed as one of the Fan surnames. This particular borrower, whose surname is Huihu, is probably also a medieval Uyghur ethnic. It shows that the Huihus also lived in the Khara-Khoto region towards the end of the Tangut era.

Инв. No. 8005-2(2), a contract with a missing first line, identifies the name of another interesting borrower. Despite the omission of his surname, the contract features his given name at the end of the document: 获萪勋 [tśhji-ta tśjow]. 获萪 was also the name of an ethnic group: the Khitans. So,

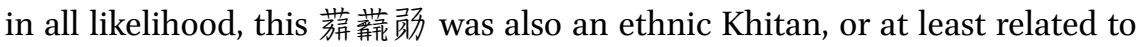
the Khitans in family kinships. This contract therefore shows that the Khitans lived in Khara-Khoto under Tangut rule. Overall, it is easy to tell from Tangut contracts that the demographic in Khara-Khoto was multi-ethnic and diverse.

Some contracts also testify to the historical practice of inter-ethnic marriage. When the borrowers and co-borrowers appear to be spouses, one Dangxiang Tangut and the other Han Chinese, the evidence seems quite convincing. In the Инв. No. 4696-3(5), for exmaple, the main Contract Party is a Han Chinese by the name of Cao Suzhou, whilst the accompanying borrower (or the contract-receiver/co-Contract Party) is listed as his wife, Eqi (née) Youbao ("Treasure of the You year"). Eqi is obviously a Tangut surname. It often occurs that the Tanguts inserted the character for 'name' (née) into their compound surname in order to indicate the lineage of a woman, which she inherited from her family. The matrimonial bond of a Han Chinese husband and a Tangut wife, as shown on this contract, is evidence of inter-ethnic marriages in the Khara-Khoto area, or, indeed, throughout Western Xia.

The Liangs were a large presence amongst the major creditors in Khara-Khoto:

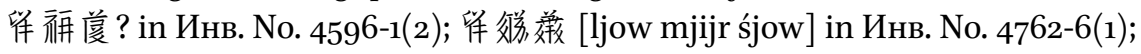
Liang "Force of Fortune" in Инв. No. 5147-1(3); Liang "Treasure of ?th Month" in Инв. No. 5870-2(2) and Liang 㖁并爱 [khjwi- wejr]; Liang (née) "the Puppet's Mother" in Инв. No. 5870-2(3); Liang "The Prosperous Tenth Month" in Инв.

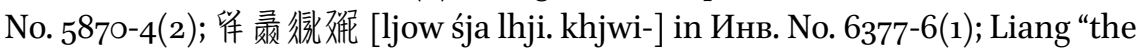
Treasure of Force and Merit" in Инв. No. 6377-16(2), amongst many others. No doubt, Liang is a major Han surname. But of course, two successive generations of matriarchal regency spearheaded by two Empresses Liang, an aunt and a 
niece, dominated Tangut politics during the reigns of Emperors Huizong and Yizong. Moreover, the Liang clans, especially the brothers and nephews of the empresses in the Liang family, occupied key positions of power in the imperial court. The Liangs advocated "Fan Customs" and sought to undermine "Han Customs," suggesting that they might not have had an inkling of sympathy for the Han Chinese cause. ${ }^{39}$ Besides, the Tangut Golden Fragments lists Liang as a Tangut "Fan name." 40 Therefore, at least the Liang family at the epicentre of Tangut ethnarchism was ethnically Dangxiang Tangut. The only logical conclusion is that both Han Liangs and Tangut Liangs coexisted in Western Xia. ${ }^{41}$

With regard to gender identities of the borrowers, it should be said, first of all, that most of the Contract Parties were men, since a typical Tangut household was patrilineal and patriarchal. Some borrowers, however, were women. In the Инв. No. 4762-6(2), the borrower is 新捘数嗳庭 [mjij pu. zji-. zji śio]

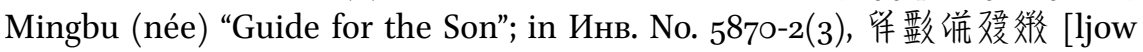
zji-. kə ta mja], Liang (née) “The Puppy's Mother”; in Инв. No. 7889(1) 勋数 橆? [tśjjow zji-. mja ? zji]: Zhang (née) "Mother? Son.” A considerable number of Tangut households were managed by and centred around women. Three families in Khara-Khoto household registers mentioned earlier (household 2, 5 and 13 in Инв. No. 6342) were all single-parent families without paterfamilias and run by an adult woman. Two of the female heads of the households were clearly labeled as child-rearing widows. ${ }^{42}$ Mingbu the "Guide for the Son" and Liang the "Puppy's Mother" were both female heads of households in charge of their families. They could have also been adult widows left with heavy burdens of and authority over their families.

Most Contract Parties signed their names, without reference to their social status nor identity. There were a few, however, who revealed their identities in their signatures, oftentimes in a few characters preceding their own names. For example, in Инв. No. 4079-13(2), we have 'the one who sets up the contract'

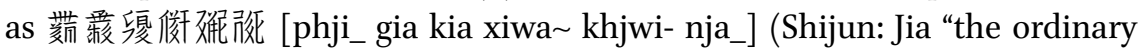

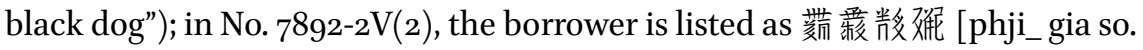
khjwi-] (Shijun: The Three Dogs); finally, the borrower in Инв. No. 7892-8(1) is

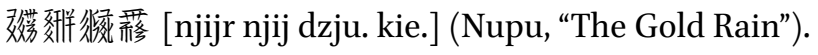

39 History of Song, Bk. 486, "Western Xia” Part II.

$40 \quad$ Nie Hongyin and Shi Jinbo, 1995 (a).

41 TN: Throughout the book (chapters 1, 4) 'ethnarch,' 'ethnarchy,' and 'ethnarchism' are my own coinages. With regard to the ethnic ambiguity of Liang, it can be said that towards the mid- and late-Tang periods, Dangxiang Tanguts who took up certain transliterated Chinese surnames share the same characters with ethnic Han Chinese names.

Shi Jinbo, 2004 (a). 


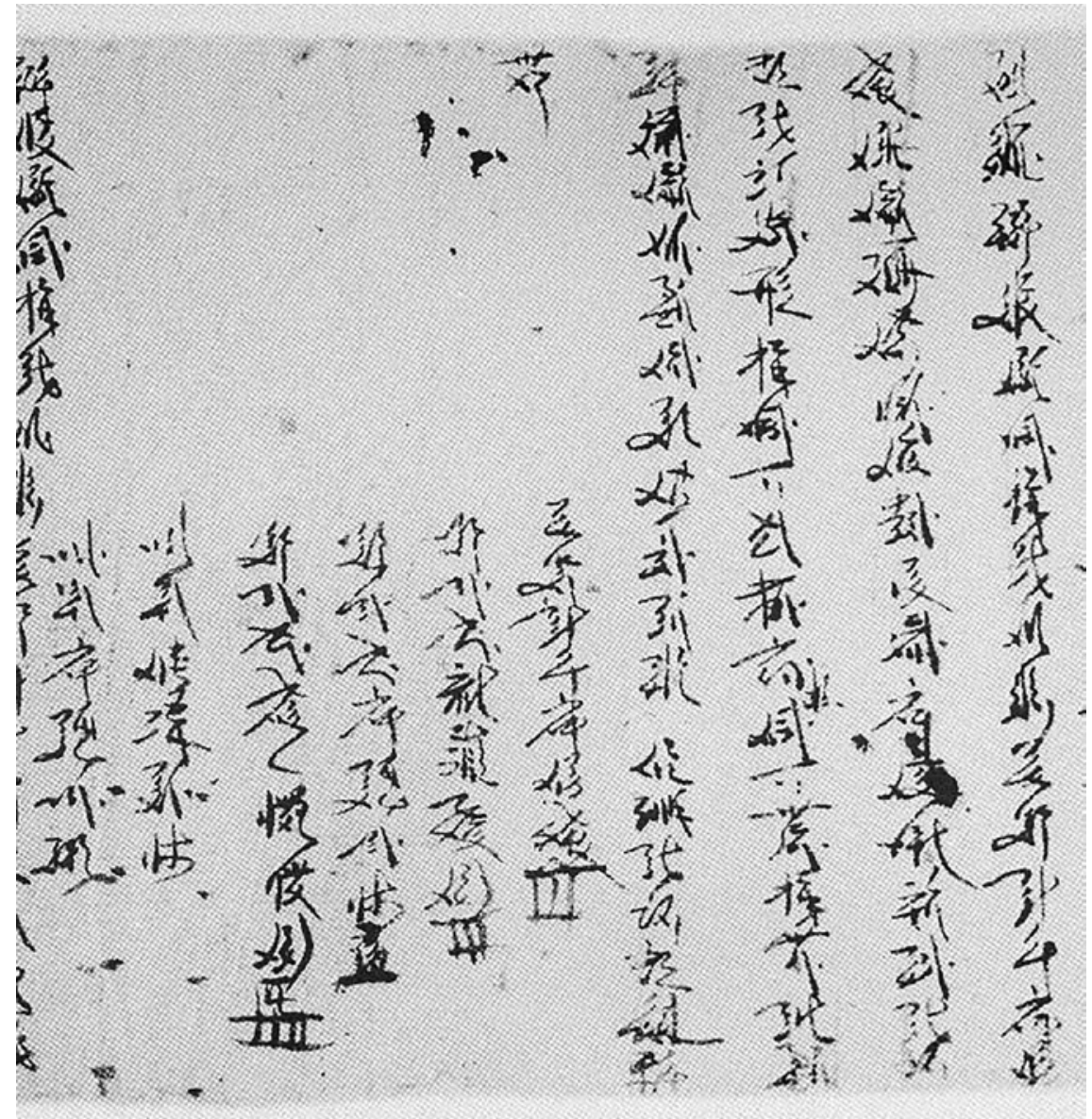

FIGURE 125 Инв. No. 4762-6 (1) (2): Yin year of Tianqing (1294) account of grain loan by Lady named Mingbu Zidao

Shijuns and Nupus formed a very special class of men and women struggling at the very bottom of Tangut social hierarchy. They were much lower in status than even ordinary commoners. Shijuns may have owned a bit of property, enough to establish and sustain a household, but they also relied on and orbited around their masters. Therefore, the Shijuns did not have 'personal freedom' in any strict sense of the term. They were more accurately described as serfs or semi-slaves.

Dunhuang contracts from the 8th to the 1oth century often list the reasons, causes, and motivations for borrowers to take loans: "for consumable grains in a year without seeds" "for use, due to the shortage of grains," "for the lack of 


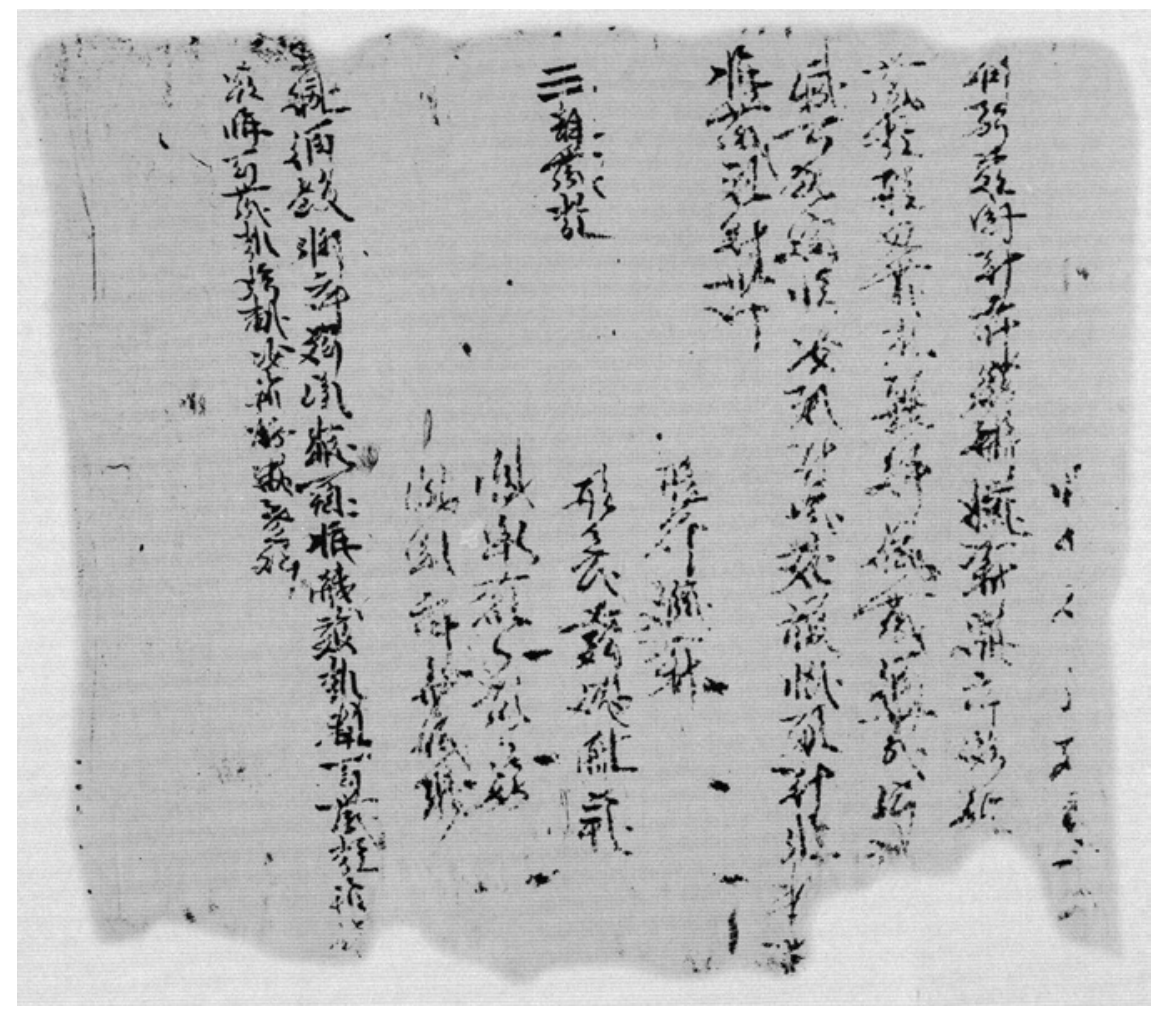

FIGURE 126 Инв. No. 7892-8: Account of grain loan by Nupu named Yujin

$h u / d o u$ "43 "because of debt," etc. Khara-Khoto contracts in the 12th-13th centuries, however, recorded only the names of borrowers, not the reasons for the borrowing. Needless to say, most borrowers took out loans because they ran short of their food supply. It does seem, therefore, that an additional line of reference to their shortage of grains is simply redundant or serves as a mere matter of formulaic language in legal rituals. So, it is likely that in the progression of time, the self-evident reasons for taking loans became an increasingly less important part of the contract, up to a point of going almost defunct. The substance of the contract are the facts and terms of the loan. However, at any rate, the precise reasons for the loans are not difficult to infer, provided the time and season of the year. Each year, the Tanguts took out loans between the last month of the previous year and the first three months of the new year to sow seeds in their fields. Sometimes, they were also hard pressed by a shortage

TN: "without hu/dou" i.e. without grains. 
of food. Whereas those who borrowed grains in the fourth and fifth months, in all likelihood, had daily consumption on their minds.

\subsubsection{Identities of the Loaners}

Needless to say, the creditors who owned enough to loan grains en masse in the barren months between two harvests came from some of the richest Tangut families in the area. In many loan contracts, the names of the contractors are followed by this line of reference to the loaner: "presently (from) xxx's place, borrow." Most of the creditors seem to be Dangxiang Tanguts: 络娏获席并爱

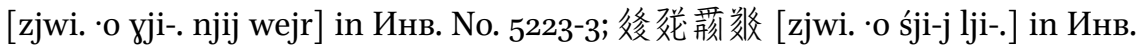

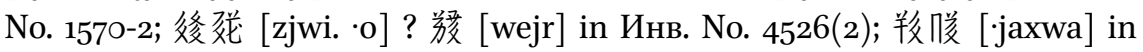

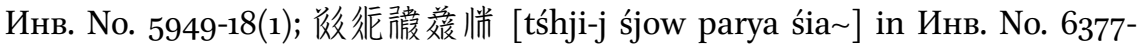

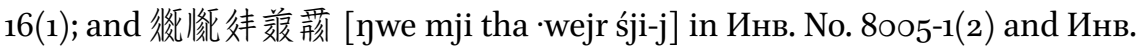
No. 8005-2(2).

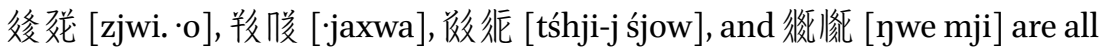
Dangxiang Tangut names. 後怰 (Weiming), in particular, was the royal name of the rulers of Western Xia. Dangxiang Tangut names have been identified in the signatures of both loaners and borrowers. It is manifestly the case that whereas some Tanguts kept on pasturing and herding, others settled—literally—for agriculture. A prominent example of an ethnic Dangxiang-Tangut creditor is "State Preceptor E," whose name appears on a loan contract in Wuwei.

The Liangs were a major family of loaners. The nine loans documented in Инв. No. 4696-1 and dozens of grain loan accounts in Инв. No. 4696-2, 3, 4, 5, 6 , as well as contracts in $7892-4,5$, all feature the signature of a certain 筹傩 倿 [ljow ne_w wejr], Liang "The Greatly Benevolent"; the three contracts in Инв. No. 5147-1, another three in Инв. No. 5147-2, 1 in Инв. No. 5147-3, and two in Инв. No. 5147-4 all list the loaner as Liang "The Iron Dog." These two figures were the most prominent creditors who offered loans on a frequent basis. They also penned contracts to lend grains to other Liangs, often at fairly high interest rates even though the borrowing parties were from the same extended family. One strange thing is that, whilst Liang "the Greatly Benevolent" loaned out grains in dozens of dan in the Mao Year of Tianqing (1195), in the Wei Year of Tianqing (1199), and in the Hai Year of Tianqing (1203), a "Liang the Greatly Benevolent"' seemed to have borrowed 4 dan of grains in the contract 7741(19), dated to the Yin Year of Tianqing (1194). There is no way to ascertain whether the borrower "Liang 'the Greatly Benevolent"' was the same as the loaner. If it was the same person throughout, then the next question is: how did he turn it all around in a year, from someone who took out loans to a creditor of grains?

The contracts also reveal eye-catching commercial activities of Buddhist temples. It turns out that these religious establishments were some of the 


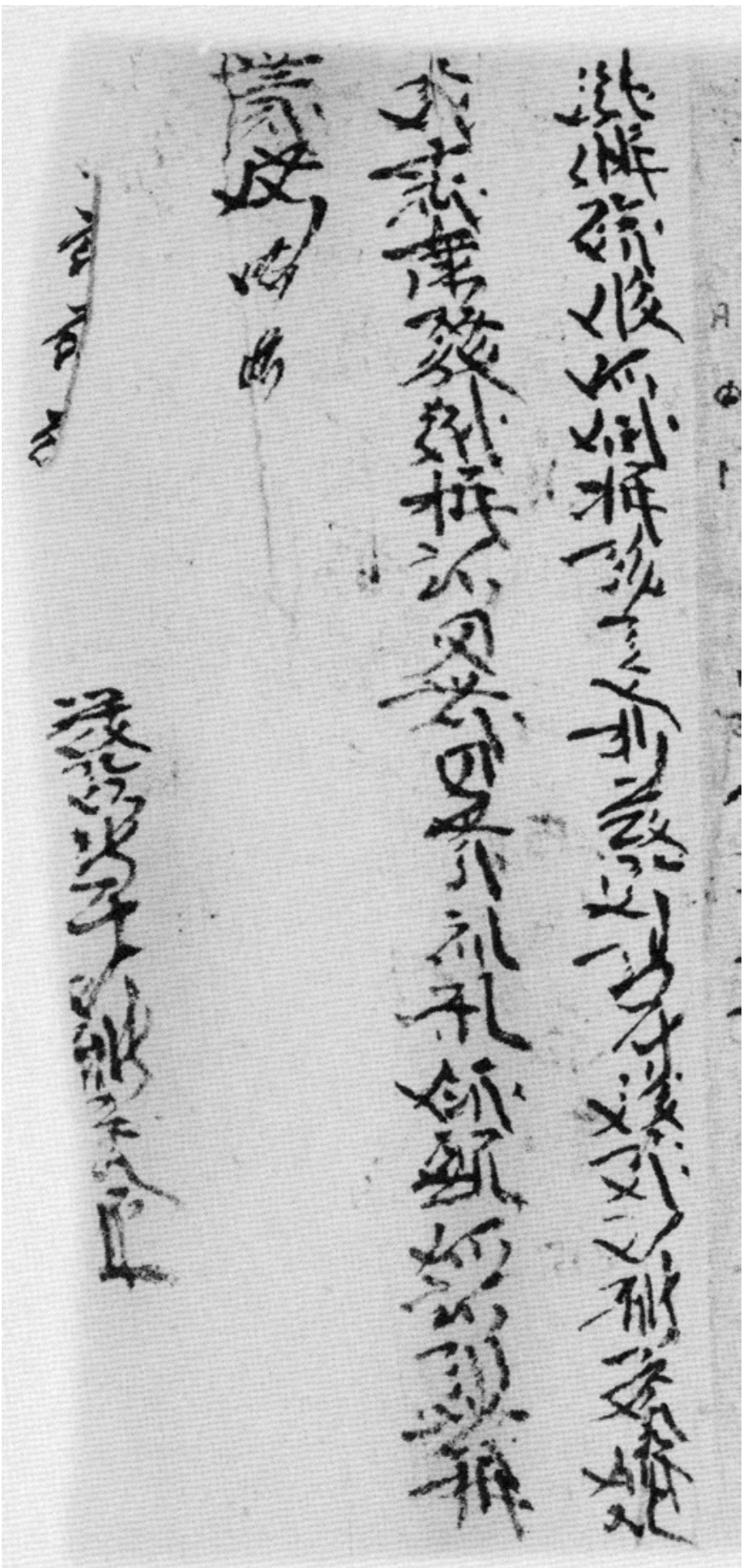

FIGURE 127

Инв. No. 5223-3:

Wei year of

Guangding (1223) account of grain loan (usurer: 聄煫 the prosperous Vajra King) 
largest loaners and usurers in Western Xia. Scores of accounts in Инв. No. 43847, 4762-6, 5870-1-9 feature two Liang-surnamed lamas from the Pudu Temple as the creditors. Both Liangs are referred to as "hand-havers' of grains." In the technical legal terminology of the Laws of Heavenly Prosperity, "hand-having" is repeatedly referred to in the sense of 'taking by hand,' i.e. the right of laying one's hands on a piece of property. Therefore, both monks were either owners of the grains or authorised personnels delegated to manage the property. But since the contracts do make sure to mention the Buddhist Temple before the loaners' signatures, it is safer to bet that the temple was the actual legal owner of the grains. In fact, there was a long-standing tradition for Buddhist temples to warehouse grains. Many creditors identified in the Dunhuang loan contracts are temples, such as Yongshou Temple, Yongkang Temple, Lingtu Temple, etc. There is a "State preceptor E" in a Wuwei contract. A "state preceptor" was a high-ranking Buddhist monastic, oftentimes also given an honorary title of the "Department of Merit" in the state apparatus. ${ }^{44}$ "State preceptor E" not only profited from usuries but charged extremely high interest rates. The exploitative economic activities of the monks form a sharp contrast to the Buddhist teachings of universal charity and benevolence.

At any rate, Buddhism was the most popular religious faith in Western Xia. It was championed by the Tangut royalties and greatly promulgated throughout the empire. Everywhere, a vast number of monks occupied a plethora of temples and pagodas. Monasteries benefited from tax exemptions, and temples occupied lands otherwise suited for cultivation by Tangut farmers. Since many Tanguts chose to enter monastic life, the government eventually resorted to setting a quota on Buddhist conversions in order to curb the growth in monastic population. ${ }^{45} \mathrm{~A}$ statistical analysis of the contracts shows that the Buddhis temples were the main and largest force in the army of creditors. The vast presence of Khara-Khoto temples in usurious loans reveals how the monastics exploited famines and other economic crises to extract surplus profits from the local poor.

Surprisingly, a number of creditors are identified as Shijun, or Tangut semi-slaves. In several contracts, such as the 38 pieces of contracts in Инв. No. 4696-3, grains were loaned out by "Shijun Wu Heicheng." And in Инв. No. 6377-20(2), despite the suboptimal legibility, the same Shijun seems to also be the loaner in this contract. How could a Shijun, himself at the very bottom

44 Shi, Jinbo. Xixia Fojiao Shilue [西夏佛教史略]: A Brief History of Tangut Buddhism. Ningxia People's Press, 1988, pp. 143-146.

45 Revised Laws of Heavenly Prosperity 11, "Constructions and Renovations of Temples for Buddhist and Taoist Monastics," pp. 407-410. 


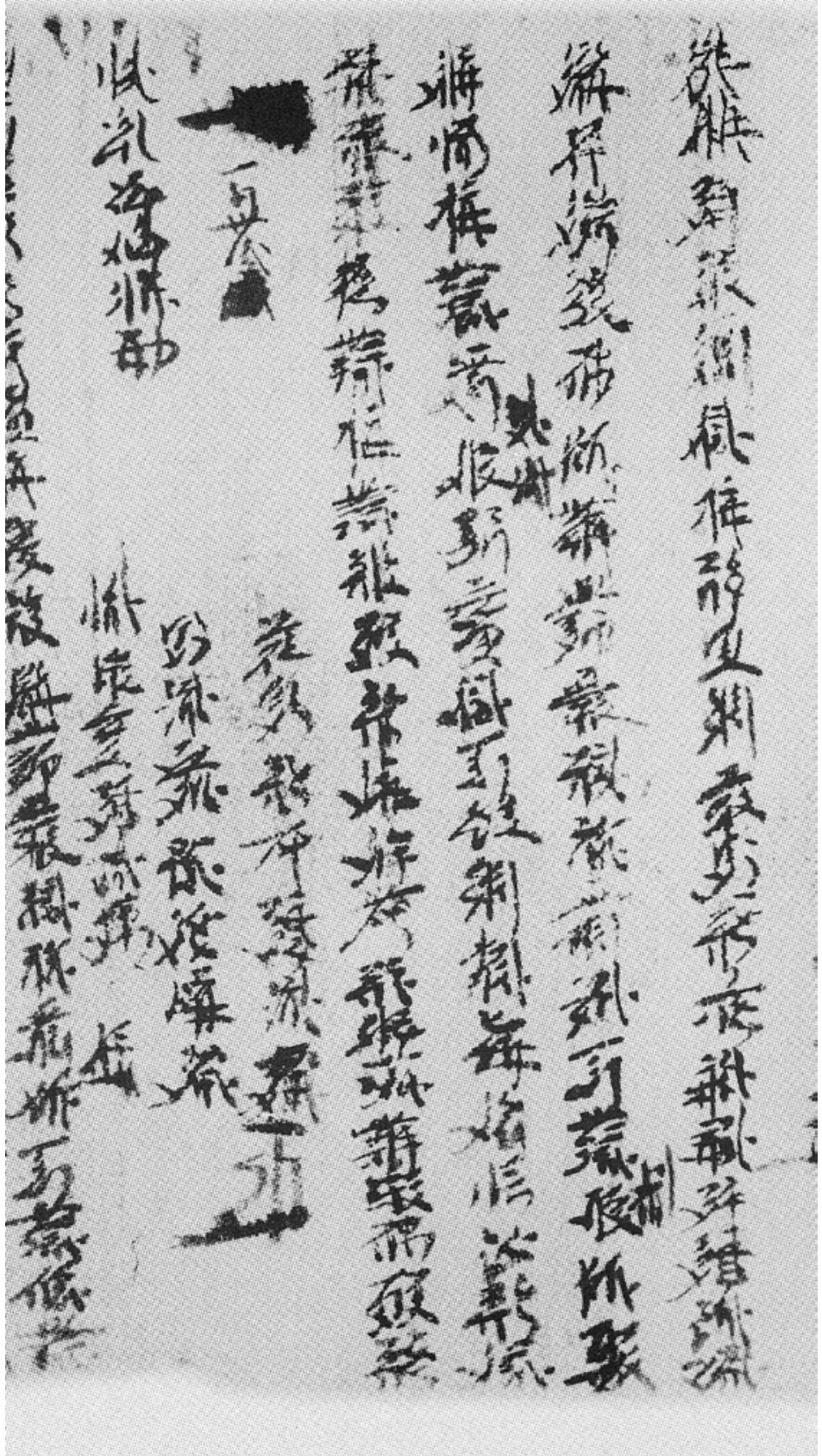

FIGURE 128 Инв. No. 4696-6: Shen year of Guangding (1212) account of grain loan (creditor: 倠挍荍; Shijun: Wu Heicheng) 


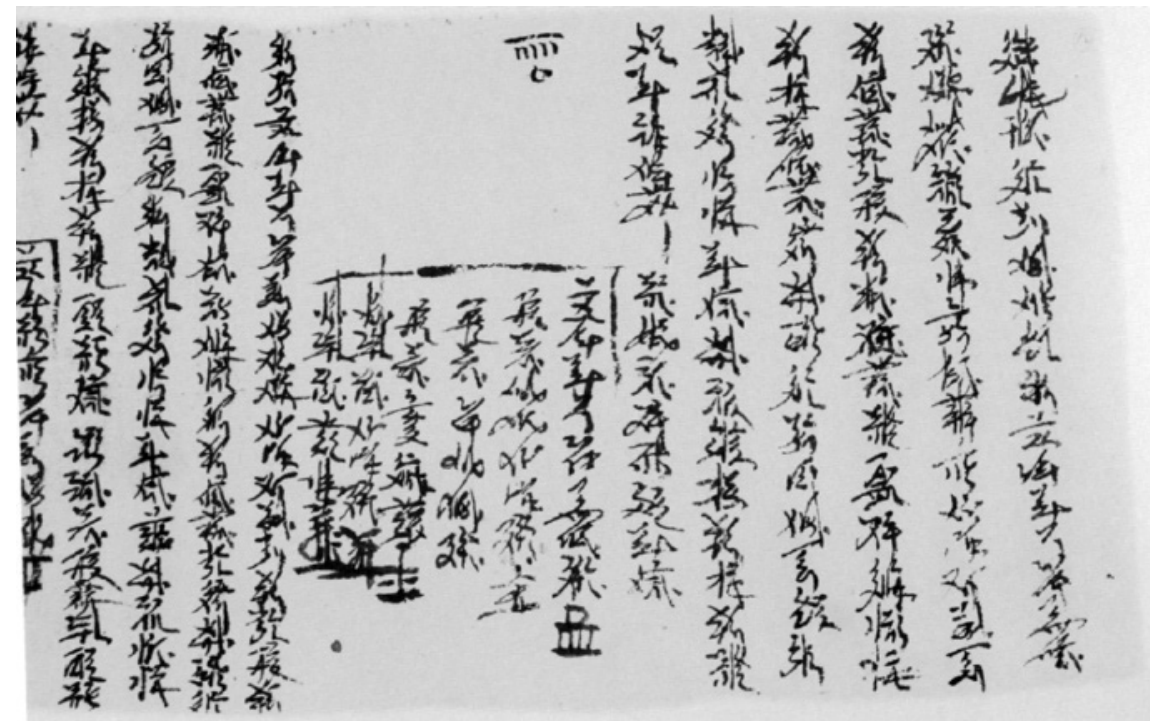

FIGURE 129 Инв. No. 6377-16: Mao year of Guangding (1218) account of grain loan (usurer:

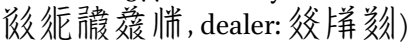

level of social hierarchy, offer loans to others? An answer lies in Инв. No. 46966 , a grain loan account in the Shen Year of Guangding (1212). It turns out that, one piece of contract in the long scroll records the full title of the loaner: "the 'holder' of the granary of Liang 'the Greatly Benevolent': Shijun, Wu Heicheng." That is, Wu was the keeper of Liang's granary. So, it is unsurprising that the grain loans were offered under his names, even though the property was owned by Liang. In other words, the Shijun acted as an agent or representative, on behalf of his master and the owner of the grains.

Throughout the nine pieces of loan contracts in Инв. No. 4696-1, Liang the Greatly Benevolent' released the loans by signing his own name. Similarly,

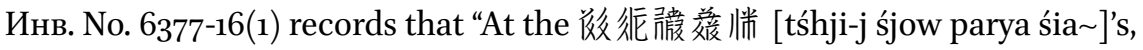
from the actual owner, from the 父拼刻 [da kia ywie] loaned 1 dan 5 dou of

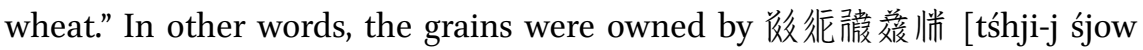
parya śia ] but loaned at the hands of 条栟茾形 [da kia śji-j]. The manuscript Инв. No. 6377-16(3), a grain loan contract in the Mao Year of Guangding (1218) states that "from Shijun 父拼刻 loaned 2 dan of wheat," leaving no doubt that the agent who handled the loan is a semi-slave, Shijun. Likewise, the one said to have 'held' the grains in the Wuwei loan contract 旅㩔举 [parya śjow] was also such an agent, rather than the owner of the property.

Simpler contracts only recorded the names of the borrowers but not those of the loaners. These 'unilateral contracts' are signed by one party but preserved 
at the hands of the opposite party. The creditors in contracts Инв. No. 5949-22, Инв. No. 5949-27-1, Инв. No. 5949-27-2, and other contracts all chose not to sign their own names.

\subsubsection{Types and Quantities of Grains in the Loans}

Most of the grains referred to in the Khara-Khoto grain loan contracts are either “敞” [lhji.] (wheat) or “政” [dza] (assorted, coarse grains). Tangut diet included wheat, barley, grains, millet, beans, and some rice. The residents of Khara-Khoto could not really enjoy rice. But apart from that, all other types of crops grew in the area. Most of the Khara-Khoto agricultural tax accounts referred to either fine wheat and coarse grains, or 祘 [lhji.] (wheat) and 航 [śjij] (barley), such as in Инв. No. 4808. The contracts show that most borrowers took loans of coarse grains. Others borrowed barley, proso (Инв. No. 77412(3), Инв. No. 7741-6(2), Инв. No. 7741-7(1)), or foxtail millet (Инв. No. 5870-2(1), Инв. No. 7741-2(2), Инв. No. 7741-6(3)). The loan in Инв. No. 4762-6(4) is 3 dan of wheat, 3 dan of coarse grains, and 1 dan of foxtail millet. The contract in Инв. No. $5^{870-2}(1)$ refers to 6 dan of coarse grains, 1 dan of wheat, and 1 dan of foxtail millet; Инв. No. 7741-2(3) refers to 4 dan of wheat, 4 dan of coarse grains, and 2 dan of foxtail millet. The fact that coarse grains and foxtail millet are mentioned separately and side-by-side in these contracts shows that the Tanguts did not count foxtail millet as coarse grains.

In the Инв. No. 7741-1(3), a borrower took out "a loan of 3 dan of wheat, 7 dan of coarse grains," but at the end, the numerical notations show 6 dan of barley, 1 dan of proso millet, and 3 dan of wheat. This shows, in the contrary, that the Tanguts considered both barley and proso millet as a type of coarse grain. Given existing knowledge of Tangut contracts, the Tanguts never referred to loans of either barley or proso millet along with "coarse grains" within the same contract. It points to the high probability that the "coarse grains" as a collective term refers to both types of crops, or a mixture of the two. But the Tanguts listed both barley and proso millet separately within the same contract, instead of a collective reference to "coarse grains." In (3) and (4) оf Инв. No. $4762-6$, for example, the loans are " 4 dan of wheat, 4 dan of barley, 1 dan of proso millet" and " 3 dan of wheat, 3 dan of barley, 1 dan of proso millet." The contract fragment in Инв. No. 3586 specifies that the loan of "cereals and wheat" was to be repaid in the amount of "coarse and refined grains, 6 dan 3 dou." Since the Tanguts considered wheat as 'refined,' the reference suggests that cereals might have been counted as "coarse."

The grain loan contract in Инв. No. 5949-22(1) notes "grain principle [of the loan]: 3 dan of coarse grains, 2 dan of wheat; [repayment of] principle and interests: altogether 7 dan 5 dou." With regard to the total sum of 7 dan 5 dou, 


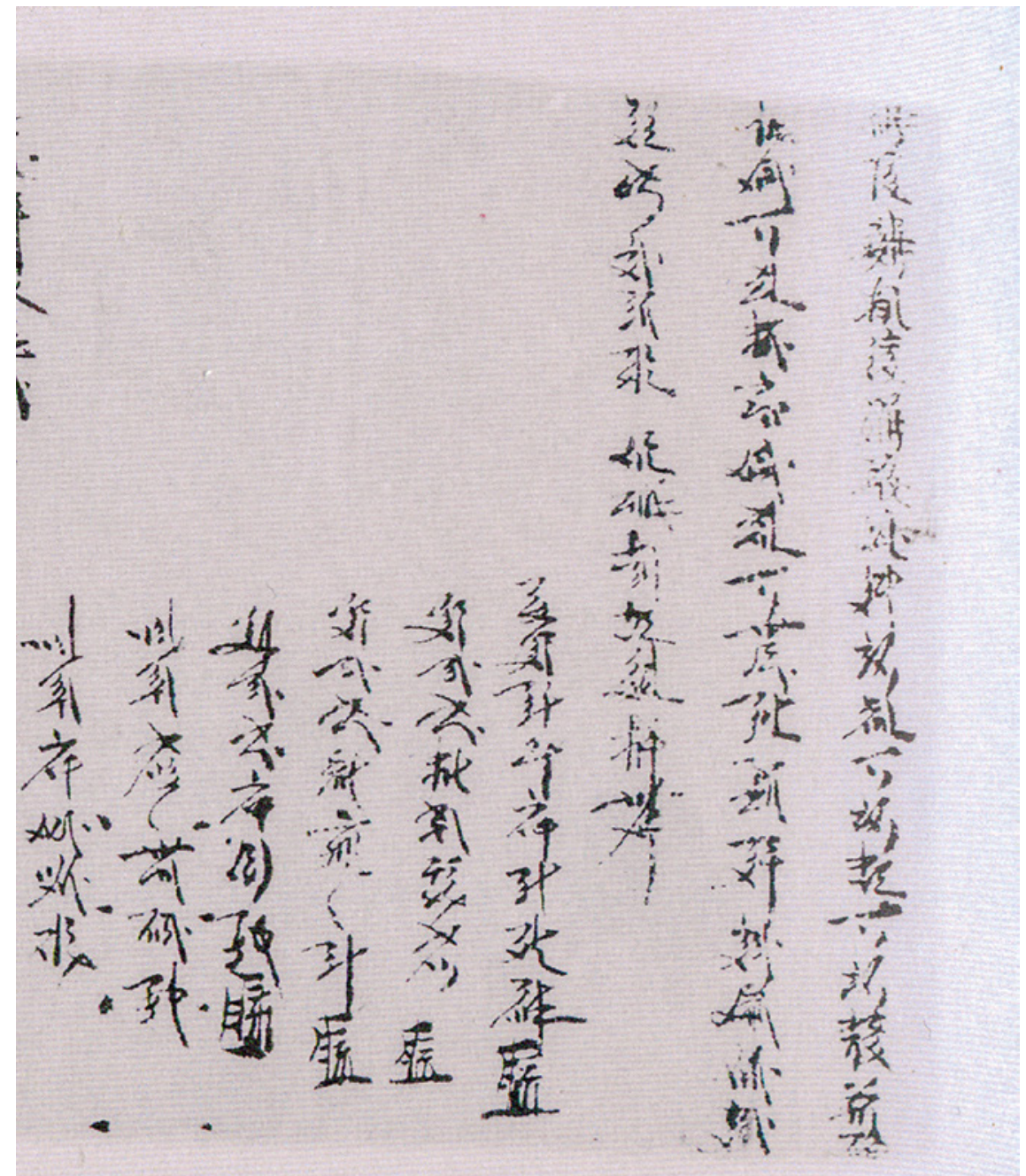

FIGURE 130 Инв. No. 5870-2: Yin year of Tianqing (1194) account of grain loan

the contract does not record the fine vs. coarse grains separately. But it is assumed that the actual repayment would be delivered in terms of both coarse grains and wheat, given the different prices of the two crops.

The grain loans recorded in Tangut contracts vary greatly in size, from a few sheng or 1 dou to several or a dozen dan. The amounts of grains loaned in the 5 pieces of contracts in Инв. No. 4696-5 are 3 dou, 2 dou, 3 dou, 5 dou 5 sheng, 5 dou 5 sheng of coarse grains; in a total of 23 contracts in Инв. No. 4696-6: 3 dou 5 sheng, 1 dou, 1 dou 5 sheng, 1 dou 5 sheng, 1 dan 5 dou, 3 dou, 1 dan 5 dou, 1 dou 5 sheng, 2 dou 5 sheng, 7 dou 5 sheng, 3 dou 5 sheng, 7 dou, 3 dou 
5 sheng, 3 dou, 5 dou, 1 dou 5 sheng, 2 dou 5 sheng, 4 dou 5 sheng, 3 dou 5 sheng, 1 dou 5 sheng, 1 dou, 5 dou 5 sheng, 4 dou 5 sheng of coarse grains. For the most part, a smaller loan was less than $1 \mathrm{dou}$, and the largest was no more than 6 dou. Only 2 loans exceeded 1 dan. Therefore, most Tangut loans were, on the whole, 'micro-loans.'

In rare occasions, however, the loans were in great quantities. The total amount of 8 grain loans by Lüzini in Инв. No. 4596 reached 29 dan 7 doи. Инв.

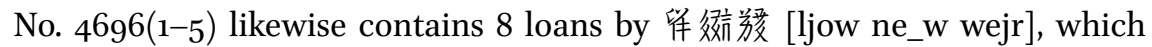
number up to 43 dan 5 dou. In Инв. No. 4696(6-7), there are 24 loans, in the amount of 15 dan 6 dou 3 sheng. And in Инв. No. 7892-7(1)-(6), 21 contracts, loaned out by Liang and mostly written in simple formats (19 loans with clear indications of the loan size), recorded up to 8 dan 6 dou 8 sheng of grains. The smallest loan was 1 dou or 5 sheng, such as in Инв. No. $7892 / 7$ \& 8. In 48

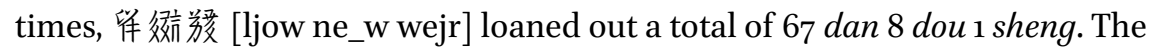
average loan was the size of 1 dan $4 \mathrm{dou}$. As of now, it is impossible to ascertain without further research whether 举该㔙爱 “the Greatly Benevolent," was monastic or not.

The contracts make it clear to historians that in Western Xia, most grain loans were offered by temples. In Инв. No. 587o(1), for example, Pudu Temple loaned out 10 dan of wheat and 4 dan of barley. In 19 pieces of contracts, the temple offered a loan of $129 \mathrm{dan}, 9 \mathrm{dou}$, and 5 sheng in total. On average, each borrower owed a bit more than 6 dan and 8 dou. The largest loan was 15 dan of wheat and 16 dan of coarse grains, totaling to 31 dan of grains. The smallest was merely 1 dan of grains. The one who took out the largest loan was called 篗耏 裳, who signed the contract on the first day of the second month. He was either in grave shortage of subsistence at home or in desperate need of a large quantity of seeds for the sowing season. He probably took the loan out on behalf of a large farming family, which would have had a large household and sizeable ownership of land. The 20 loans documented in the Инв. No. 7741 contracts, also offered by the Pudu Temple, amount to a total of 147 dan of grains. Pudu Temple is also the listed creditor in the seven contracts in Инв. No. 4384-7. Only two pieces survive, which show a loan of 6 dan. All the 41 pieces of contracts in three registers were signed by Pudu Temple within the span of the Yin Year of Tianqing (1194). In total, the temple loaned out 282 dan 9 dou 5 sheng of grains. This is only a scratch of the surface because these are only the contracts that happened to have survived. As for how much loans the monks at the Pudu Temple offered in total within that year, there is no way to ever know. But here, it is telling that each single loan is considerable in size: an average of 6 dan and 9 sheng per loan, up to five times more than the average loan offered by 铸傩 誁 [ljow ne_w wejr], "the Greatly Benevolent." 
For a minority of rich temples and families to persist in the lucrative business of offering usurious loans, there must have been a majority of the Tangut poor in a perennial shortage of grains. Song chronicles made sure to mention the plight of food shortage in Western Xia:

The northwest suffers a shortage of the five grains. Whenever wars break out, the provision of grains is limited to barley, the bi beans, ${ }^{46}$ abutilon, ${ }^{47}$ and the sort. The people in that area consume the stems of guzi flowers ${ }^{48}$ and jianpeng seepweeds ${ }^{49}$ in the spring; seedings of Cistanche herbs ${ }^{50}$ and little wuy $i^{51}$ in the summer; $x i j i z i,{ }^{52}$ dihuang leaves, ${ }^{53}$ dengxiang grass $^{54}$ in the autumn; 'sandy onions', ${ }^{55}$ wild chives, ${ }^{56}$ jushuang, ${ }^{57}$ grey tiao grass, ${ }^{58}$ white mugwort, ${ }^{59}$ jiansongzi $^{60}$ in the winter, as a means of subsistence at the turn of the year. ${ }^{61}$

The image of Tangut commoners feeding on assorted wild herbs all year long is probably a slight exaggeration. However, given the rates, terms, and amounts of grain loans in Khara-Khoto contracts, it is obviously true that a significant

46 TN: 華豆 is different from piper longtum.

47 TN: for the lack of a better translation for 青麻.

48 TN: 鼓子蔓 most probably refers to the tenderer seedlings or stems of 鼓子花 or a close relative of it, within the Convolvulaceae ('morning-glory') family. Some botanical and medical journals list it as Calystegia silvatica subsp. orientalis. Historically, the plant was common in northwestern China. Nowadays, it is very rarely consumed as vegetables.

49 TN: These days, 碱蓬 (Suaeda glauca) weeds are still consumed as vegetables in China.

$50 \mathrm{TN}$ : 䒘蓉 (Cistanche deserticola) a type of Cistanche in the family of Orobanchaceae, still a medicine and delicacy, known as a specialty of Hotan and the Alxa League.

$5^{1} \quad$ TN: There are two types of Wuyi (無荑), large and small. It is processed from the seeds of Ulmus macrocarpa (fructus ulmi macrocarpae preparatus).

52 TN: It is unclear what 席雞子 is, other than a type of egg or a herb, probably halophyte.

53 TN: 地黃葉: leaves of Rehmannia glutinosa (Gaetn.) Libosch., a key herbal medicine.

$54 \mathrm{TN}$ : 登厢 is a type of grass that grow in sandy areas of nothwestern China. Both the grass and the seeds are edible.

55 TN: 沙葱 (Allium mongolicum), also known as 蒙古非, is a type of wild onion that grows in northwestern China, Inner and Central Asia.

56 TN: Chinese chives (Allium tuberosum).

57 TN: 拒霜, or 木芙蓉 (Hibiscus mutabilis Linn.).

$5^{8}$ TN: I take 灰菠子 to be, instead of a type of mildly poisonous medical herb known otherwise as 龍葵草, an edible herbal grass: 菠, that is pronounced tiao or diao.

59 TN: 白蒿 (Herba Artimisiae Sieversianae) is edible and commonly used as medicine. It is similar to Artemisia argyi (silvery wormwood).

$60 \mathrm{TN}$ : 碱松子 is most probably a halophyte plant.

61 Zeng Gong, Long Ping Ji, Bk. 20, “The Barbarians [夷狄傳]: The State of Xia [夏國].” 
proportion of the population suffered constant shortage of food and the general hardship of life.

\subsubsection{Interests and Interest Rates in Grain Loans}

All Tangut loan contracts thus far identified were contracts of personal loans with interests, which detail the amounts of the principle and interests, sometimes even the total sum to be repaid by a certain date. In comparison and contrast, most of the Dunhuang grain loan accounts and contracts only emphasise the repayment deadline and specify that an overdue payment would result in the principle multiplying beyond the due date. Whereas 7 th-century contracts found in the Western Region document the interest rates in detail, they have a close resemblance to the Khara-Khoto contracts. ${ }^{62}$

The Khara-Khoto loans not only generated interests, but the interest rates were, for the most part, exorbitant. All the principles appear to be the basic amounts of grains taken out as a loan. But with regard to the interests, there seems to be three main ways of calculating the rate.

\subsubsection{Total Interest Rate, Based on the Principle}

For a grain loan that bears interests for three to four months, the interests in sum amounts to half of the principle. Some of the contracts refer to "change by a half," that is, to increase the repayment by $50 \%$ of the principle. Thus, the final repayment would be 1.5 times of the principle. In this case, a given contract would clearly document the principle amount and the interest rate as well as specify the due date by which the total sum was to be repaid, typically in the seventh or eighth month of the lunar calendar. This interest rate at $50 \%$ is found in Инв. No. 4596-1(1), a contract of 2 dan wheat that yielded a total repayment of 3 dan; in (3), the loan of 1 dan wheat and 1 dan coarse grains (2 dan in total) demanded a total repayment of 3 dan; in Инв. No. 4526(2), the borrower took out a loan of 5 dan coarse grains, with a promise to pay back 7 dan and 5 sheng; in Инв. No. 5147/1(3), the 1 dan of wheat yielded a total of principle and interests in the amount of 1 dan and 5 dou (1.5 dan); the contract Инв. No. 5223-4(2) documented a loan of coarse grains in the amount of 2 dan 8 sheng, whereby the debtor was under obligation to repay 4 dan 3 dou 2 sheng, as a total sum of both the principle and the interests. The Инв. No. 5949-41(1) effectuated a loan of coarse grains in $8 \mathrm{dou}$, which resulted in a repayment of

62 Trombert, Éric. Le crédit à Dunhuang —Vie matérielle et société en Chine médiévale. Paris: Collège de France (Institut des hautes études chinoises), 1995. 
1 dan and 2 dou in total; the Инв. No. 80о5-3(2) documented a loan of 1 dan 5 dou of wheat that required a repayment of 2 dan 2 dou 5 sheng. All the examples above belong in the category of $50 \%$ interest rate. This rate was extremely high for a short-term loan of three to four months.

And yet, even higher interest rates have been identified. According to a piece of contract fragment in Инв. No. 2158, a borrower took out a loan of wheat in 2 dan, bearing an interest of 6 dou per dan. By the time the total repayment was due, he had to pay back 3 dan and 2 dou of wheat, that is, at an interest rate of $60 \%$. What is more, in Инв. No. 7889(1), the wheat loan in the amount of $6 \mathrm{dou}$ was taken at the interest rate of 8 sheng per dou. A total repayment reached up to 1 dan and 8 sheng, at an interest rate of $80 \%$. Likewise, the state preceptor $\mathrm{E}$ of Wuwei released a loan of 1 dan that charged an interest of $8 \mathrm{dou}$, which was also at a rate of $80 \%$.

That, however, is not the end of the story. Interest rates reached up to $100 \%$ in Western Xia, similar to what is known as "doubling interest" (倍稱之 息) in the Song Dynasty. In the Инв. No. 4696-1(1), a grain loan contract in the Mao Year of Tianqing (1195), the debtor borrowed a loan of wheat in 8 dan and was due to return precisely 16 dan of wheat, which was twice the amount of the principle and at an interest rate of $100 \%$. Another example is the contract Инв. No. 4696-3(8), signed on the $25^{\text {th }}$ day of the 4th month, whereby 1 dan of coarse grain was repaid in $2 \mathrm{dan}$; an additional 2 dou of coarse grains was due to be repaid with $4 \mathrm{dou}$. More astonishingly, these repayments, at the exorbitant interest rate of $100 \%$, were due by the 1st day of the 7 th month in the lunar calendar, a mere space of 2 months and a few days from the signing date of the contract. And in the Инв. No. 5949-19(3), whilst the principle was listed as 4 dan, 2 dou, and 5 sheng of wheat along with 10 dan and 4 dou of coarse grains, the due amount was 29 dan, 2 dou, and 2 sheng. This amount was very close again to an interest rate at $100 \%$, which would have been 29 dan 3 dou. This discrepancy of 8 sheng was due either to miscalculation or to certain norms governing the conversion of fine grains to coarse grains.

It is also worth considering that although some loans were offered at the interest rate of $50 \%$, the charge was much higher when taking into account the shorter time frame of the loan. For instance, in Инв. No. 5949/16(1), a loan of 8 dou coarse grains was offered on the 29 th day of the $5^{\text {th }}$ month. By the $15 t$

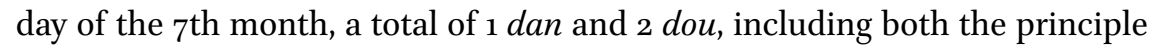
and the interests, was due. If the interest rate for 1 month was $50 \%$, then if the borrower had been in debt for just another month, he would have effectively been subjected to a $100 \%$ interest rate. 


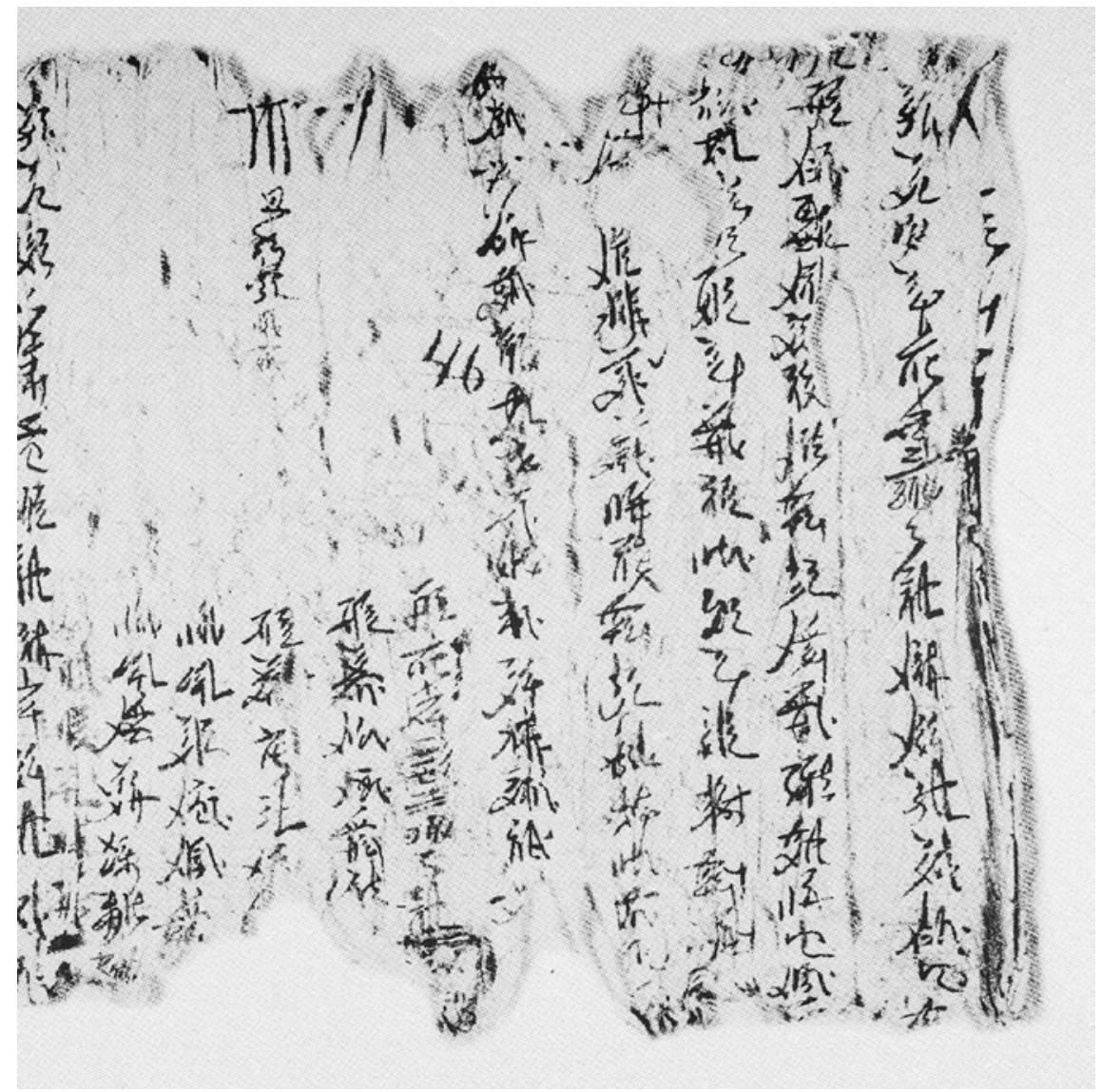

FIGURE 131 Инв. No. 4696-1: Mao year of Tianqing (1195) account of grain loan

\subsubsection{Monthly Interest Rate}

An interest rate charged on top of the principle grains on a monthly basis could also reach the $100 \%$ rate. Indeed, this was another way of imposing a 'doubling interest rate.' In the contract Инв. No. 4762-6(1), for example, the borrower took out a loan of wheat and barley, each in the amount of 10 dan, on the 29th Day of the 1st Month. The loan officially began on the 1st day of the 2nd month. Every month, the loan generated 2 sheng of interests per dou of principle, at a monthly interest rate of $20 \%$. The contract notes that this arrangement would remain in force "until the interest equals the principle." Although the document does not supply a precise due date by which this was to be achieved, it is easy to derive from the terms that, at least in the progress 


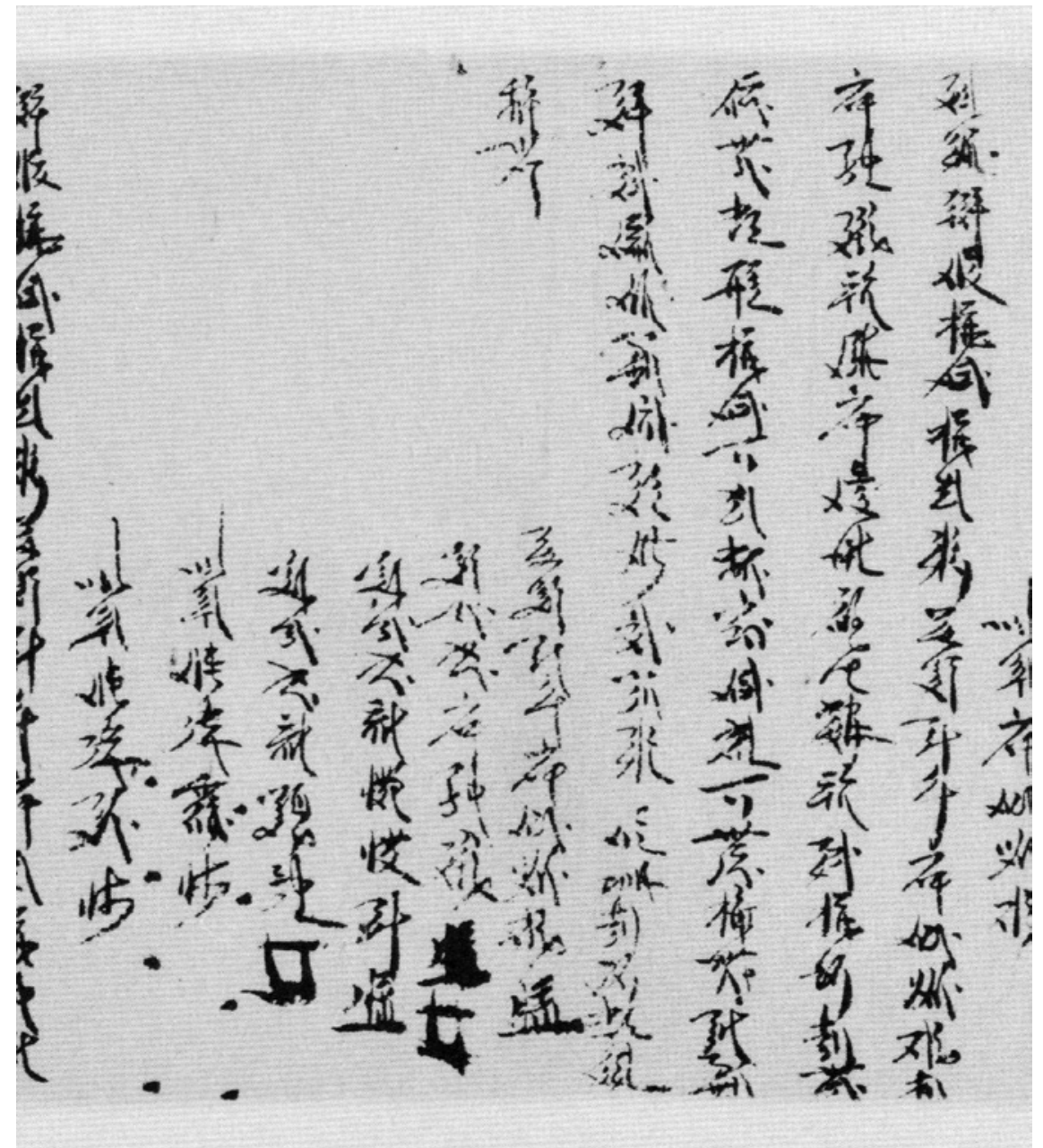

FIGURE 132 Инв. No. 5870-2(2): Yin year of Tianqing (1194) account of grain loan

of five months - that is, till the 1st day of July - the total interest rate would virtually become $100 \%$. By July, the debtor would have to turn in 20 dan of wheat and barley each. Likewise, in Инв. No. 5870-2(2), a contract signed into effect on the 2nd day of the 2nd month, the borrower took out a loan of 2 dan 3 dou 5 sheng of wheat. From the 1st day of the 2nd month to the ist day of the 7 th month, a monthly interest of 2 sheng was applied per dou of the principle, at an interest rate of $20 \%$. By July, the total interest reached $100 \%$ of the principle in the original loan.

Another example is a piece of loan contract unearthed in Khara-Khoto by the Institute of Archaeology of Inner Mongolia. The register " 84 H.F135: 
$\mathrm{W}_{75 / 2026}$ " is a grain loan contract signed on the $5^{\text {th }}$ day of the 2 nd month in the Year Yihai. The contract required the debtor to repay a monthly interest of 1.5 dou per dan borrowed., i.e. a monthly interest rate of $15 \%$. If the loan bore interest for half a year, the rate would reach up to $90 \%$. A full repayment by August would entail 2 dan 8 dou 5 sheng, effectively doubling the principle. This is an obvious example of a usurious loan.

A certain 留耏裳 was the borrower of 31 dan of grains, as listed in the contract Инв. No. 587 . The loan started in the 2nd month of the year, at a monthly interest rate of $20 \%$. Both the interest and the principle-62 dan in totalwere due back in the $7^{\text {th }}$ month. With this arrangement, the interest rate also reached up to $100 \%$.

\subsubsection{Daily Interest Rate}

Some loans bore daily interests out of the principle. In Инв. No. 5812-3(1), for example, the 1 dan and 5 dou of grains were to be repaid on the basis of “䇉

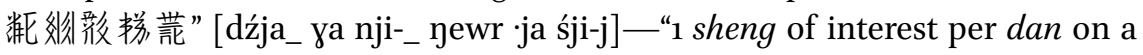
daily basis," in other words a daily interest rate of $1 \%$. But in a progression of 100 days, the interest rate also reached $100 \%$. Similarly, with a loan of 1 dan of coarse grains in Инв. No. 5812(2), the contract required "half a sheng of interest in five days," i.e. a daily interest of $1 \%$ (0.5 sheng of interest per 1 dou of grains in 5 days). In 100 days, the interest rate also reached $100 \%$.

In some rare occasions, the interest rates surpassed $100 \%$. The contract in Инв. No. $7892 / 8(3)$ recorded that " 8 dou of interest for 7 dou of

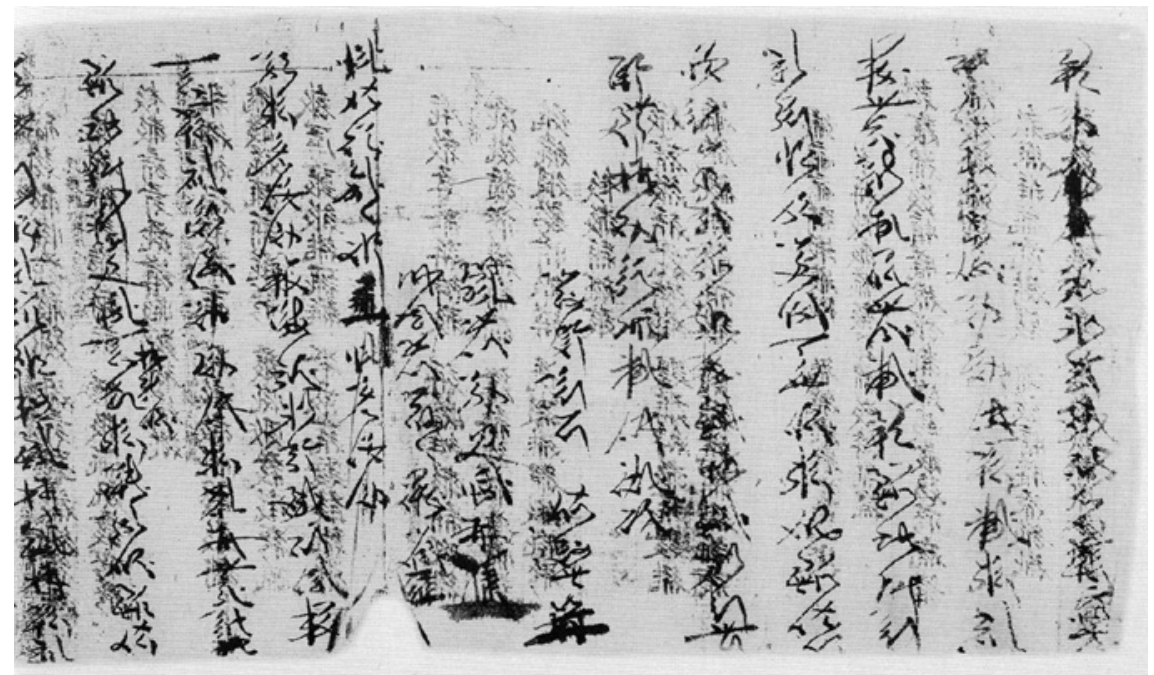

FIGURE 133 Инв. No. 5812-3(1): Account of grain loan 
wheat," which suggests an interest rate of $114 \%$. But according to the Laws of Heavenly Prosperity:

Where the many release public or private wealth in the country as loans, with the principle in terms of grains, for each string $(\mathrm{min})$ of cash, there may be an amount of interest under 5 mace; for each $h u$ (dan) [of grains], there may be an interest under $1 \mathrm{hu}$; in such cases, interests may be charged on a voluntary basis, and should not exceed these limits. ${ }^{63}$

This law set the limits to both monetary and grain loans: A daily interest of 5 mace or less for each string/min of cash coins (daily interest rate: $0.5 \%$; monthly interest rate: $15 \%$ ); a total interest of 1 hu (i.e. 1 dan) or less for each hu/dan of grains, regardless of time. Such legislations put a cap on usuries, to the benefit of the borrowers. The Tangut laws also required that:

With regard to the aforementioned terms of loans, aside from rendering clear the laws of generating interests from the principle taken out as the principle, it is necessary that with daily, monthly, and annual payments, or payments over the years whilst the principle is held in possession, as soon as the interest equals the principle, no one is permitted to exceed this amount. If a party receives more interest than this maximum according to the law, let a guilty office-holder be punished by the confiscation of a horse, and let a guilty commoner be punished by thirteen strokes. The extra amount of interest unlawfully charged should be duly returned to its lawful owner. ${ }^{64}$

This law underscored the due procedure of loans and interests. It stated that a grain loan may bear interests over days, months, and years, in a variety of rituals and formats. However, the creditor may not charge any surplus interest as soon as the cumulative interest equaled the principle - that is, as soon as the cumulative interest rate reached $100 \%$. This regulation is, in fact, reflected in contracts of various types that circulated amongst the Tanguts. However, actual contracts were much more complicated than the straightforward demands of the law. In some contracts, the virtual interest rate charged had effectually soared beyond $100 \%$. These contracts showed, on the one hand, that violation of the laws did occur, and on the other, that the laws were enacted for a reason. The Tangut laws went to great lengths to spell out the limits on

63 Revised Laws of Heavenly Prosperity 3, "Urging the Payment of Debt," pp. 188-189.

64 Revised Laws of Heavenly Prosperity 3, "Urging the Payment of Debt," p. 189. 
usurious loan interests, the terms of redistribution of excessive interests back to the exploited borrower, and the penalties for an overly greedy creditor. All of these were legal measures that shield the debtors from undue interference and excessive economic domination by the creditors. Still, many of the helplessly impoverished opted for usurious loans for their own survival and at their own risks. High-interest usurious loans may have alleviated the plight of hunger and even death, but often times, the ahead-of-time consumption multiplied in the autumn. Most of the meager harvest went into the pocket of the creditors, leaving the peasants with little grains for subsistence. This vicious circle of poverty was often exacerbated by natural disasters, such as fire and famine, pests and pestilence, and other myriad causes of a bad harvest. If whatever surplus amount was not enough for seeding and consuming, the debtor would be further indebted in the following spring and summer. They once again took out loans in order to sow and eat. Therefore, for the Tangut poor, to take out a high-interest usurious loan was to 'drink the Zhen bird's poison to quench one's thirst' as the Chinese idiom goes. These loans often led to nothing but bankruptcy. To pay back the loans, peasants sold off their land and houses. These transfers of property further aggravated the wealth inequality of Tangut society and even caused social instabilities. The Tangut proverb, "In the second and third month, do not eat food on a loan; in the eleventh and last month, do not wear clothes on a loan," was a vivid testimony to the fear of exploitation at the hands of usurious loans. ${ }^{65}$

\subsubsection{Terms of Payment and Default Penalties}

There was only one growing season in the Khara-Khoto area, and the annual harvest was timed around the seventh and eighth months of the year. Therefore, most of the grain loan contracts also set a due date between these two months. Contracts were specific about the terms of repayment, and most loaners asked the debtors to return the principle and interests by the first day of either the seventh or the eighth month. The contract Инв. No. 5820-2, for example, required that "due date be the first day of the eighth month in the same year, when the debtor is obliged to gather and repay all the owned grains." The contract Инв. No. 5949-16 specified that "due date is set at the first day of the seventh month, when all the grains are to be gathered and repaid." The lines on due dates were usually followed by the terms of penalties in terms of delay or failure of repayment. There were two modes of punishment.

65 Chen Bingying. Xixia Yanyu [西夏諺語]: Tangut Proverbs. Taiyuan: Shanxi People's Press, 1993, pp. 13-14. 


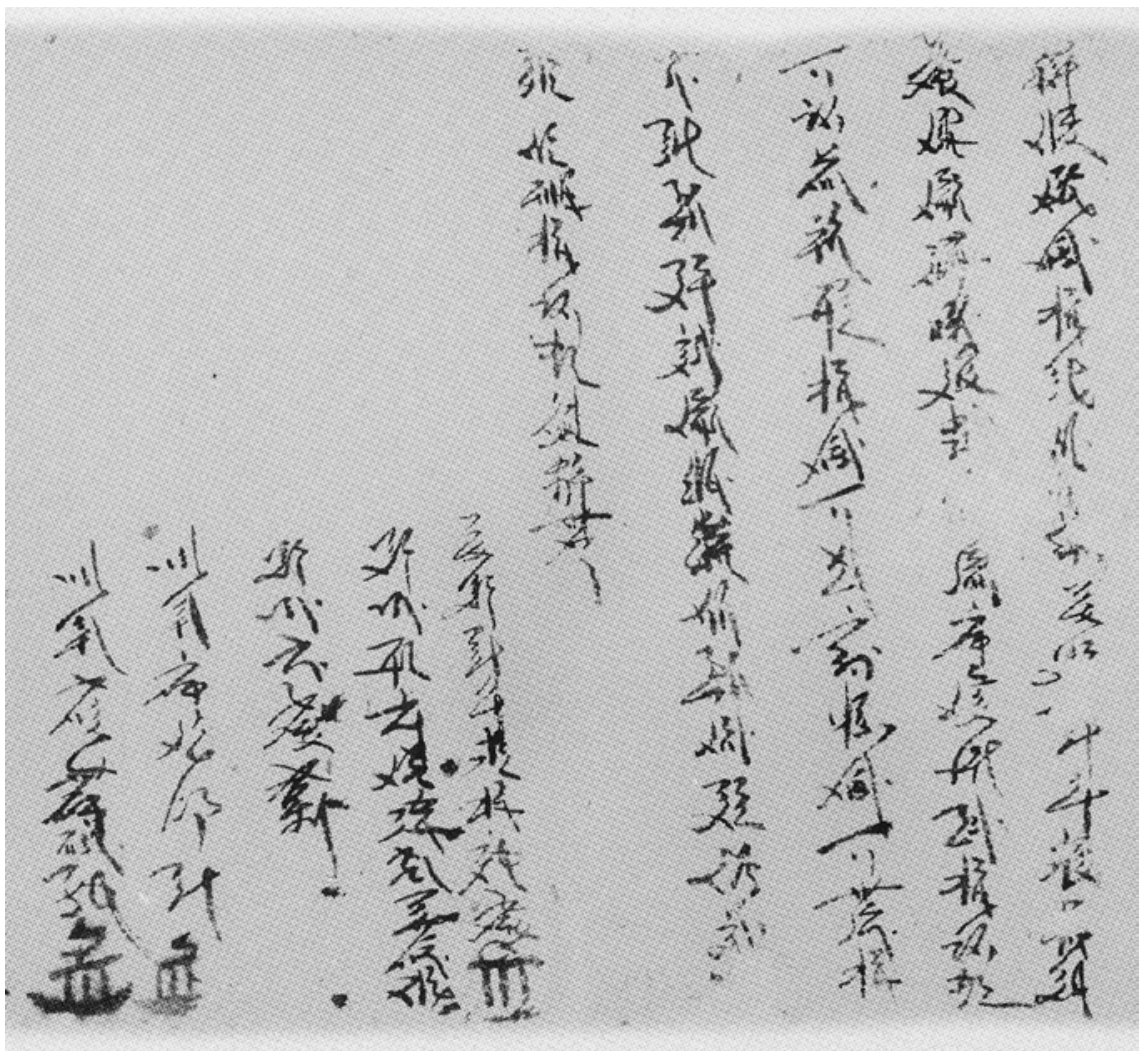

FIGURE 134 Инв. No. 4384-7(1): Yin year of Tianqing (1194) account of grain loan

The first was to penalise the borrower with extra grains, according to the size of the loan in question. The loan concerned in the document Инв. No. 4384-7(1) involved 2 dan of wheat and 1 dan of coarse grains. The contract required that "when the repayment is overdue, the penalty is 2 dan of wheat according to the laws; willing." That is, the borrower was willing to be subject to the penalty fee in accordance with laws.

In fact, the terms of penalties were set by the loaners, who took advantage of their ownership of grain surpluses protected by the laws. So there would be no other option for the debtor than to note down "willing" in the contract, regardless of their actual willingness and despite their reluctance. Likewise, in Инв. No. 4384-9(2), the debtor borrowed 2 dan of barley and 1 dan of coarse grains. By the contract, he had to pay " 1 dan of wheat according to laws, in case of overdue repayment; willing." And in Инв. No. $5870(1)$, whereby the borrower took out a loan of 10 dan of wheat and 4 dan of barley, the contract stipulated that "in case of overdue repayment, the penalty is 10 dan of wheat according 
to the laws; willing." All these references, and many others, fall into the same category of penalty, which is set at a particular quantity.

Another approach to penalising overdue or unmaterialised repayment was to set a particular ratio, rather than a fixed amount. The contract Инв. No. 4596-4(3) states, for example, that "if the borrower does not show up past the due date, 2 dan of penalty fee is to be applied to each dan of unrepaid loan; if the debtor is incapable of furnishing this much, he is responsible for enlisting his own people to repay the sum; (debtor's) own mind is willing." In other words, overdue payment would result in 2 dan of penalty fee per 1 dan of loan. A thoroughly impoverished debtor would have had to divide the surcharge into chunks and implore others to repay on his behalf. Needless to say, the debtor's 'own heart' submitted to the rule. Similar terms of requirements were found in Инв. No. 5949-18 and other contracts.

The section on "Urging the Repayment of Debt" in the Laws of Heavenly Prosperity protected the interests of loaner and the rights of the creditor. The chapter opens with a straightforward call for coercion in urging for repayments:

All the concerned parties are to press the debtors for the return of the principle and interests; in case of failure to repay, it is necessary to report the incident to the relevant bureau, in order that coercive search and investigation be adopted to materialise the repayment. In case of failed repayment of debt in the amount under 10 strings of cash, an office-holder is to be punished 5 strings; a commoner is to receive 10 strokes; for an amount of debt above 10 strings of cash, an office-holder is to be punished by the confiscation of a horse; a commoner is to suffer 13 strokes. In all cases, the debt is to be repaid in accordance with the requirement of law. Any attempt to deny an existing debt is strictly prohibited. Any violation of law in this regard is to be treated in the same category as the failure to repay. The principle is to be returned, and the debt to be repaid according to the laws. ${ }^{66}$

Terms of penalty are different for officeholders with social and political status and for commoners without privileges. ${ }^{67}$ Whereas the elites were penalised by cash and horses, the commoners suffered the ferocity of lashes. After the 10 or 13 strokes, the criminalised remain obliged to repay the debt in full. The Laws

66 Revised Laws of Heavenly Prosperity 3, "Urging the Payment of Debt," pp. 189-19o.

67 Shi, Jinbo. “Xixia de Zhiguan Zhidu” [西夏的職官制度]: “The Bureaucratic System of Western Xia” in Lishi Yanjiu [歷史研究]: Historical Research, issue 2, 1994, pp. 62-71. 
of Heavenly Prosperity also made it clear that the party defaulting on the terms of a contract would be duly prosecuted:

A party that thereafter reneged on the terms of the contract are to fulfil the obligations either to the public authority or to a private party; the repudiator of the terms, if an office-holder, is penalised by the confiscation of a horse; and if a commoner, by thirteen strokes. ${ }^{68}$

The second item in the laws of "Pressing the Repayment of Debt" offered some leniency to the debtor incapable of repayment:

All the relevant parties who fail to repay their debt, and remain incapable of returning the sum after admission of their guilt, are to be given another 2 or 3 extensions of the deadline, according to their distance, so that they may procure more means of repayment, such as to repay by labour. But in case of repeated defaults, the debtors are to receive strokes of a certain number, calculated based on the size of the debt. In case of persistent default after three granted extensions, let the laws be strictly applied with no more leniency. ${ }^{69}$

The law was open to the possibility of repaying debt by labour. Yet, repeated defaults resulted in physical penalties. The maximum application of leniency was capped at three times. These measures of leniency were put in place, ostensibly out of a spirit of compassion but ultimately for the expediency of the creditors. They preferred fulfilling their economic interests to unleashing brute force for the pleasure of vengeance. Without some flexibility, it would be extremely difficult to receive the principle and interests at all. At any rate, it is not difficult to see that the reference to "overdue repayment penalised according to the laws" in the contracts was not a technical formality or empty words of deterrence. Rather, it was backed up by robust institutions of imperial criminal laws.

It is also worth noting that although the laws offer the option to repay debt by labour, this practice was not confirmed in the grain loan contracts found in Khara-Khoto. So, there is a slight mismatch between the law code and the contracts, in this wise.

Another point of interest is a comparison with the loan contracts in Dunhuang. The Dunhuang contracts deterred financial defaults by the threat

68 Revised Laws of Heavenly Prosperity 3, "Urging the Payment of Debt," pp. 189-19o.

69 Ibid., p. 188. 
of penalty fees multiple times greater than the principle: "to suffer the confiscation of familial properties, to repay the debt in terms of grains"; "to bear the confiscation of household properties and miscellaneous goods to repay the debt accrued in wheat"; "to suffer the confiscation of family properties, miscellaneous goods, and the cattle, etc."70 These contracts warned the debtors of the prospect of suffering the coercive confiscation of their properties in cases of default. These documents even made specific arrangements on how properties were to be converted to cash and grains as well as how much was to be confiscated. These measures easily gave rise to disputes and conflicts. Moreover, it is not clear where the juridical power resided in judging, overseeing, and enforcing these procedures. Without thorough stipulations on these terms, it was difficult to enforce the contract by simply letting the process unfold between the creditor and the debtor, without giving rise to even graver conflicts. In general, Tangut contracts differed from Dunhuang contracts in that the former did not contain such challenging requirements. The Laws of Heavenly Prosperity also did not make reference to the forceful confiscation of properties in cases of default. But there is no doubt that the Tanguts mortgaged their livestock and even human beings in their contracts. Some of these legal documents provide detailed accounts of the items pawned and mortgaged: type and outlook, quality and quantity. Certainly, in cases of overdue payment or default, the creditor had every right to receive the transfer of these properties according to the terms set out in the contract. These preventive measures that involved the practice of pawning and mortgaging will be discussed later. But at least the reasonable anticipation of a property transfer into the hands of the creditor in lieu of debt repayment was more normative and easier to imagine than an opaque reference to a "confiscation of household properties." Perhaps this difference also speaks to the refinement of legal loopholes of earlier laws, from Tang to Tangut periods. Along with or as a result of the socioeconomic developments, medieval contract laws did evolve and improve over time. It is also found in the Laws of Heavenly Prosperity that:

If the co-borrower cannot repay the sum either, it is still not permitted to pay the debt with these two parties' wives, daughters-in-law, or unmarried daughters. It is permitted, however, to pay the debt by their physical labour. ${ }^{71}$

$70 \quad$ Dunhuang Economic Documents, pp. 76-147.

71 Revised Laws of Heavenly Prosperity 3, "Urging the Payment of Debt," p. 189. 
This stark prohibition of repaying debt by the borrower's and the co-borrower's female kins speaks to the historical practices of either selling women, or at least selling their labour for debt payment. Of course, the transaction of women was not absent in these historical periods and in societies where women occupied the lower status of social hierarchies. However, the Tangut law code explicitly prohibited the transaction of women, either for profit or for debt payment. It shows at once the existence of such commercial activities, and the strong measures adopted by the empire to stamp out this crime.

Signatures and Stamps of Concerned and Relevant Parties at the End of the Contract

The signatures and stamps of the principle and relevant parties at the end of a contract are critically important components of the legal procedure. Signatures and stamps endowed an effectual legal force to the contract as a document, thus guaranteeing the enforcement of the terms. Contracts without signatures and stamps were deemed ineffective. As for a certain number of Khara-Khoto contracts that do not show stamps and signatures, it is likely that they are drafts rather than official documents.

\subsubsection{The First to Sign and Stamp Is the Borrower}

Grain loan contracts usually begin and end with the stamps and signatures of the borrower, with the expression, "Contract Party $x \times x$ ". The names could appear in full or only in the given name, thus omitting the family name. Elsewhere, the reference to 'Contract Party' is missing, replaced by "the one who repays the grains," i.e. the borrower. For example, this is evident in the manuscript Инв. No. 162-12, an account of grain loan fragment. There are also contracts that refer to the 'borrower,' such as in Инв. No. 4696/1(1)(2), etc. In Инв. No. 1570-2 and Инв. No. 7977-7, however, the borrower is listed as a 'formal borrower,' whereas his son was de facto the principle party in the loan.

\subsubsection{Signatures and Stamps of Borrower(s) and Other Liable Parties at the End of the Contract}

In order to doubly ensure the proper and prompt return of the principle and interest, the loaner sometimes also required, in addition to the stamp and signature of the debtor and family relatives, the name of "the borrower who receives the contract," "receiver of the contract," "the borrowing party" "hand-receiver of the loan contract," etc. These 'co-contracting parties' were quasi-guarantors, warrantors, or referees affiliated with the borrower. In cases where the debtor defaulted, died prematurely, escaped, or goes into exile, these co-contracting 


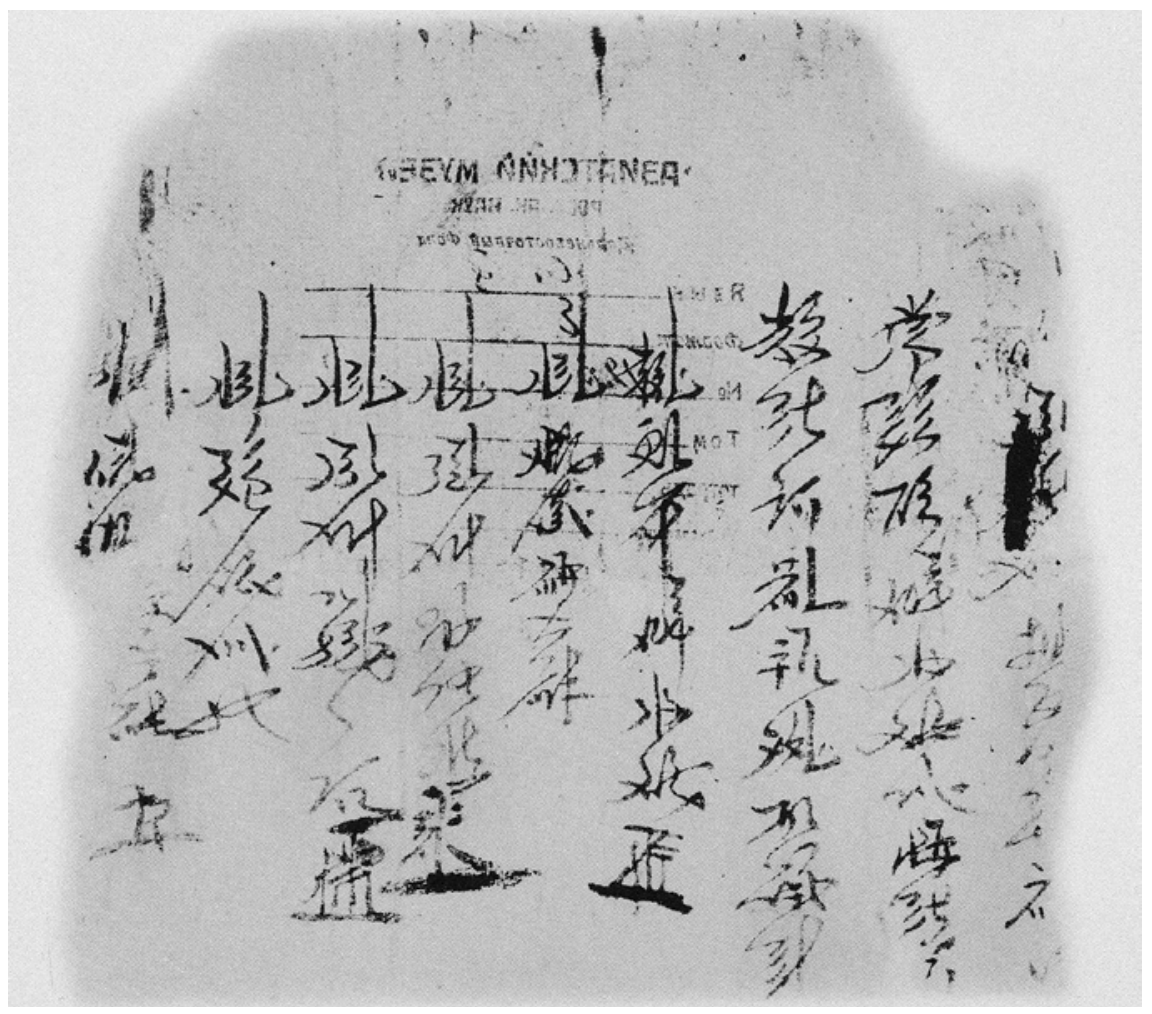

FIGURE 135 Инв. No. 162-12: Account of grain loan

personalities would shoulder joint and several liabilities in the context of the concerned contract.

There may be one or multiple co-Contract Parties. They were either wives, sons, or other kinsmen and relatives. In the manuscript Инв. No. 4596(1), an account of grain loan dated to the Chou Year of Guangding (1217), the name of

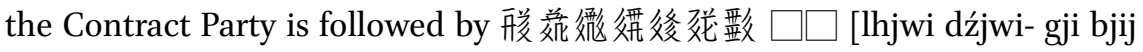
zjwi. ·o zji-. $\square \square$ ]: "co-borrower, wife: 络婘 [zjwi. ·o] $\square \square$." At the end of the contract Инв. No. $5870(13)$, the name of the Contract Party is followed by that of his wife, "co-receiver of the contract, wife: Liang the Joyful and Benevolent Treasure," a proof of the couple's joint liability. The Инв. No. 7741 (4) (6) (8) (9) (10) (11) (12) (13) (14) (15) (16) all feature the stamps and signatures of the Contract Parties' wives as co-Contract Parties at the end of the contracts.

Sometimes, the account of grain loan does not specify 'wife' as an affiliation at the end of the contract, but the spousal identity is surmised with some ease and safety. For example, the manuscript Инв. No. 954 features at the end of the contract a reference to "hand-receiver of the loan, Liang the Treasure 


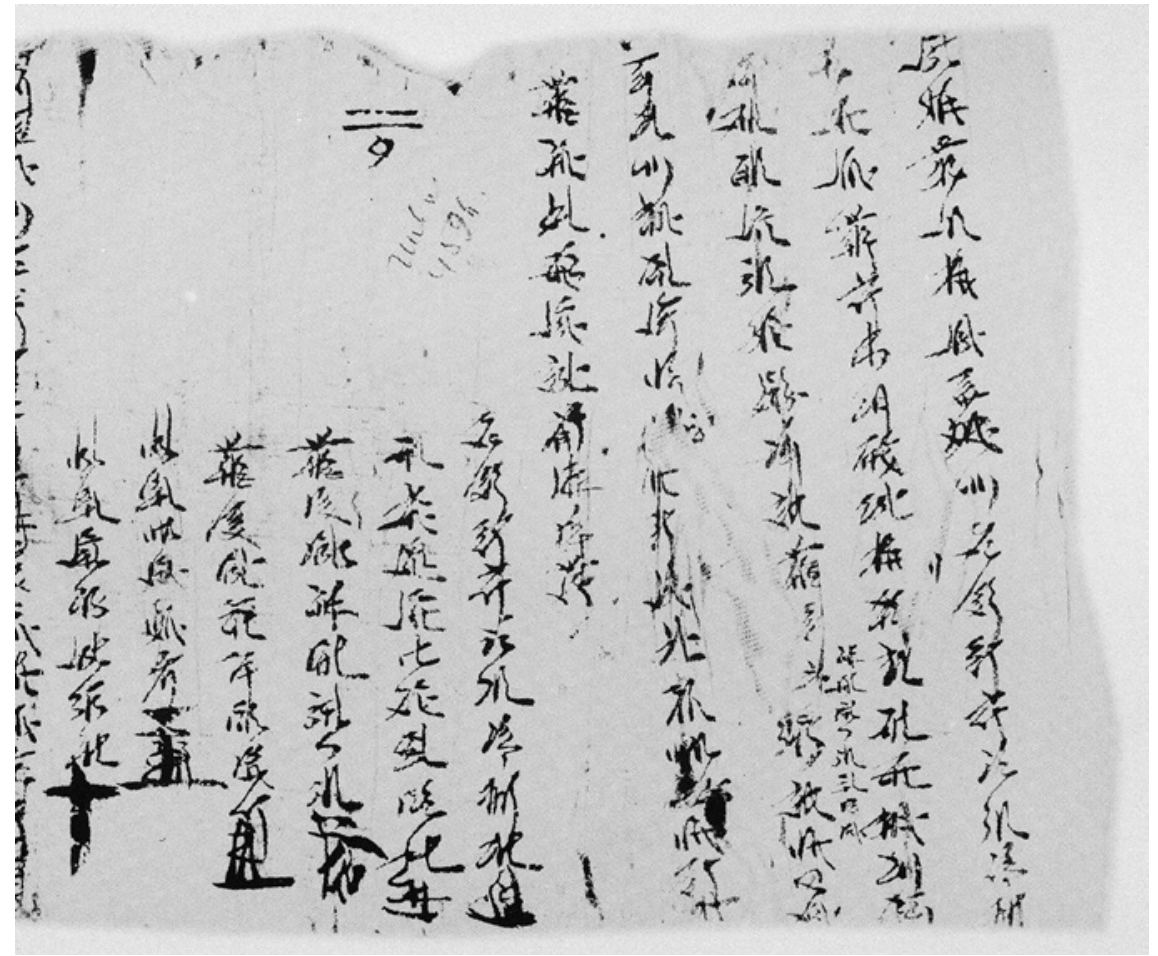

FIGURE 136 Инв. No. 4596(1): Chou year of Guangding (1217) account of grain loan

of the Benevolent Moon," who is most probably the wife of the principle Contract Party "Eyi the Puppet Mount." Similarly, the "borrower who receives the contract: Xishang Treasure of the Seventh Month" in Инв. No. 4384-7, the "Meina the Treasure?" in the Инв. No. 7741(18), the "receiver of the contract Ming? Brother's Guidance" in the Инв. No. 7741(1), may all be the spouses of the debtors. Dunhuang loan contracts feature fathers and sons, elder and younger brothers as guarantors, but curiously, not wives. The fact that the Tanguts relied on their wives as warrantors in formal contracts speaks to a relatively higher socio-economic-legal status of women within and beyond the domestic spheres of the household. Indeed, the prevalent practice of having professional housewives bear the legal burden of financial debt formed a sharp contrast to the Central Plains during the same period and to the diverse and dynamic Dunhuang area in the Tang Dynasty. But of course, this phenomenon could as well be an extended effect, if not a natural consequence of the historically higher status of women within the Tangut society.

In Инв. No. 5949-23(1), an account of grain loan dated to the Si Year of

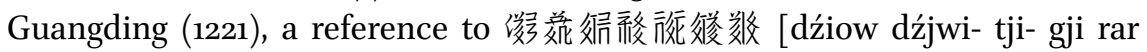


mə lji-.]: "(co-receiver) of the contract: son Luo the Accomplished Treasure" is found after name of the principle Contract Party at the end of the contract. It clearly points out that the co-borrower with joint liability was the son of the principle Contract Party. The son's family name, however, is listed as "Luo" in abbreviation, rather than the fuller "Luoming" in his father's name. Naturally, when the father was no longer capable of full repayment, the son inherited the debt. This arrangement belongs with the historical legal tradition that is best summarised in the saying, "the son pays his father's debt."

The abbreviation, or even omission of the son's family name on the assumption that he shared the same name as his father, finds additional evidence and testimony in Инв. No. 4762-6(1). The stamps and signatures of the Contract

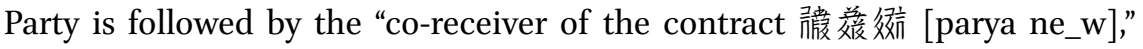
whose relationship to the debtor is noted as "son." Because the son inherited the same family name as his father, and 澱媿傩 (Bore-benevolence) was

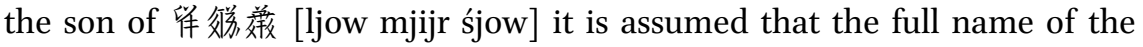

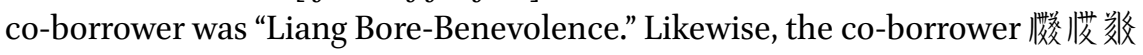
[śja dji-j lji-.] "Dhyāna-samādhi (Chan-ding) Treasure" in the contract Инв. No. 4762-6(3) probably sharesd the same last name as the principle Contract Party 倠效? [ljow pho khjwi-] because the relationship of the former to the latter is noted to be "son." But more curious and striking is the appearance of the stamps and signatures of another figure between the father and the son: the "co-receiver of the contract, wife: Su the Five Joys." In the light of this peculiar order, it does seem that in some families in rural Tangut communities, the spouse of the male figure claimed a higher economic status than the son. ${ }^{72}$

Some "co-receivers of the contract" were not necessarily kinsmen and family members of the debtor, but more distant family relations or even close friends. The Инв. No. 5147-1-3(1) was co-signed by "co-receive of the contract Qiluo 'the one with the force" and "Liquo the Dhyāna-samādhi Treasure"; the chief borrow was Liang "The force of Longevity." The Liang and the Qiluos don't seem like they were from the same household, at least on the paternal side; and the Qiluos were most probably not the spouse(s) of the debtor.

Another point worth noting and calling our attention is the Инв. No. 7741 account of grain loan from the Yin Year of Tianqing (1194). The borrower who signed at the end of one contract turns out to be the warrantor, or-borrower,

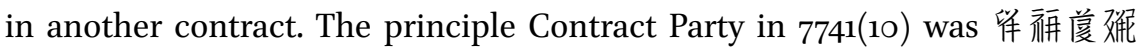
[ljow dow zji-r khjwi-], who appears in the same register (11) as 栧㣪 Bore's

72 TN: That is, in contrast to common understandings of situations in the Central Plains, whereby the son of the patriarch is for the most part the second highest on the socio-economic ladder. 


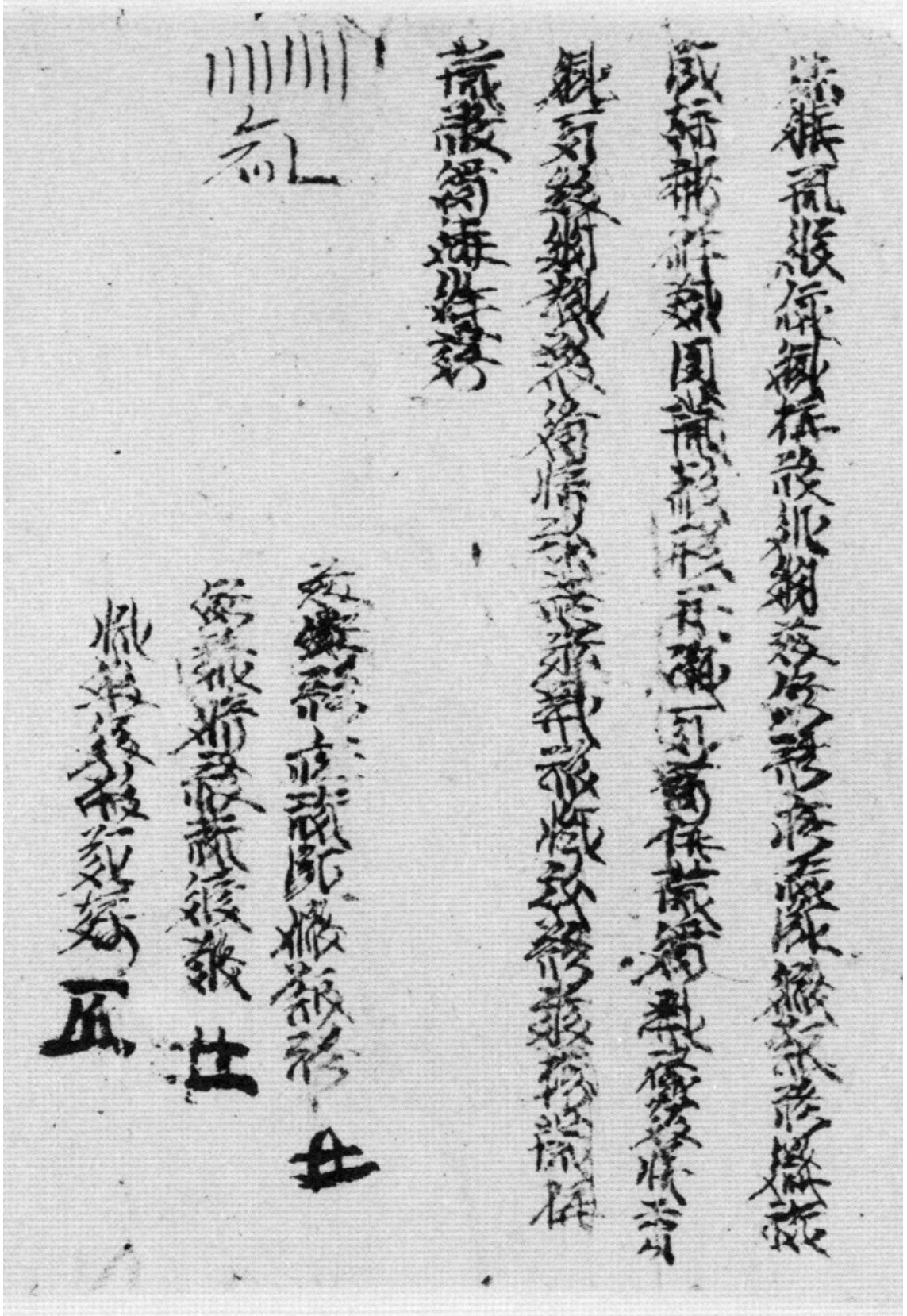

FIGURE 137 Инв. No. 5949-23: Si year of Guangding (1221) account of grain loan 


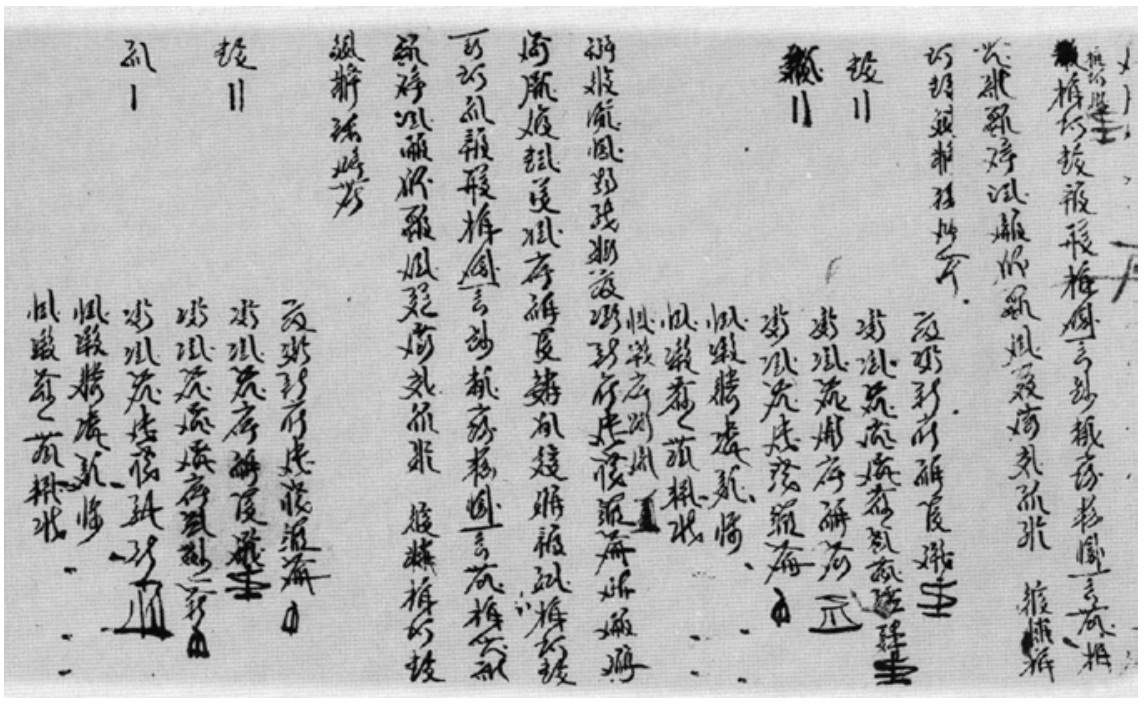

FIGURE 138 Инв. No. 7741(4) (11-12): Yin year of Tianqing (1194) account of grain loan

guarantor, as well as the co-borrower of 倠䄈裳in (12), of 㣝僙“The Benign Dog” in (13), and of 留䄈賞貌 in (16) all within the same register. Likewise, the principle borrower 浅䵊 Bore in 7741(11) co-signed the contracts of others in (10) (12) (13) and (16) of the same register; The borrower 倠福裳 in 7741(12) served as guarantors in contracts (10) (11) (13) in the same register. Obviously, these three figures served as each other's guarantors across contracts. Their loans are dated to the 3oth day of the first month and the 1st day of the second month on the lunar calendar. It can be conjectured that these three people warranted for each other's grain loans, based on their acquaintance, collective need, and mutual trust. They might have been distant relatives, close friends, or neighbours.

In most of the loan contracts found in Dunhuang, the debtor and co-borrowers were required to provide information on their age in addition to their signatures. In the Khara-Khoto contracts, however, Contract Parties did not note down their age.

Upon the successful signing of a contract, the creditor was left with the one and only hope that the principle and interests would be returned promptly and properly. The rights of the creditors were well protected by the legal regime founded upon the Laws of Heavenly Prosperity. The laws provided several means of enforcement, measures that were not only coercive in cases of default, but also procedural, so "when the debtor is no longer capable of 
repayment, press the co-borrower."73 The laws confirm our impression from the contracts that the co-borrowers were de facto warrantors with joint liability. According to the terms specified in the contracts, they would take over and assume the financial-legal responsibility of repayments in case the principle Contract Party(s) defaulted, died, escaped, went into exile, or encountered any unexpected accidents that prevented them from repaying in full. In this way, the rights, interests, and profits of the creditors were further strengthened and protected under law.

The Laws of Heavenly Prosperity also stipulates that,

If the sons, daughters, daughters-in-law, grandchildren, and brothers invite themselves to take out loans of livestocks, grains, cash, and properties, either government-owned or from the private sector, without the proper knowledge and acknowledgement of their parents and brothers who dwell and dine in the same household, and if they thus incur interests, and act in an inopportune and inappropriate time, with the consequence that their properties evaporate into nothingness, the parents may repay the debt if they do agree to bear the financial burdens, but are not legally obliged to repay the sum if they do not agree to do so. In the latter case, the borrower, or debtor, would have to shoulder the responsibility alone. ${ }^{74}$

In other words, family members were provided a shield of financial security in cases of major defaults by their kins. Under such circumstances, the family relatives, especially the parents who were legally responsible for the financial arrangement of the household, had the option of either extending a helpful hand to their families who took out loans without having notified the family, or leaving the audacious adventurists to their own financial ruins. In this case, certainly without the legal force that came with the ritual and record of co-signing the contract, there is a possibility that joint financial liability was not necessary. On the other hand, the co-borrowers had no choice but to share liability in case of default. What accounts for the different levels of legal obligations between the unaware parents and the fully cognizant co-signers was, of course, their respective lack of information. Thus, legal obligation was not immediately implied in degree of familiarity and affiliation but defined in the strict terms of the contract as a legally effectual and enforceable document.

73 Revised Laws of Heavenly Prosperity 3, "Urging the Payment of Debt," p. 189.

74 Ibid., pp. 190-191. 


\subsubsection{The Third Undersigned Party Is the Witness to the Transaction}

The legal terminology for the "witness" to a financial loan or transaction is usually expressed in the two-character phrase, 版漖 [nwə dzjwo], literally "the knowing person," or "the cognizant person," i.e. a "witness." There were usually two or more "witnesses," sometimes numbering up to six of them as a group of witnesses. Some served as the witness to multiple loan contracts. For example,

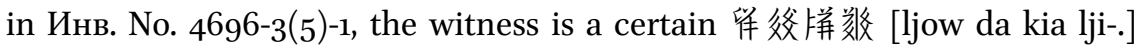

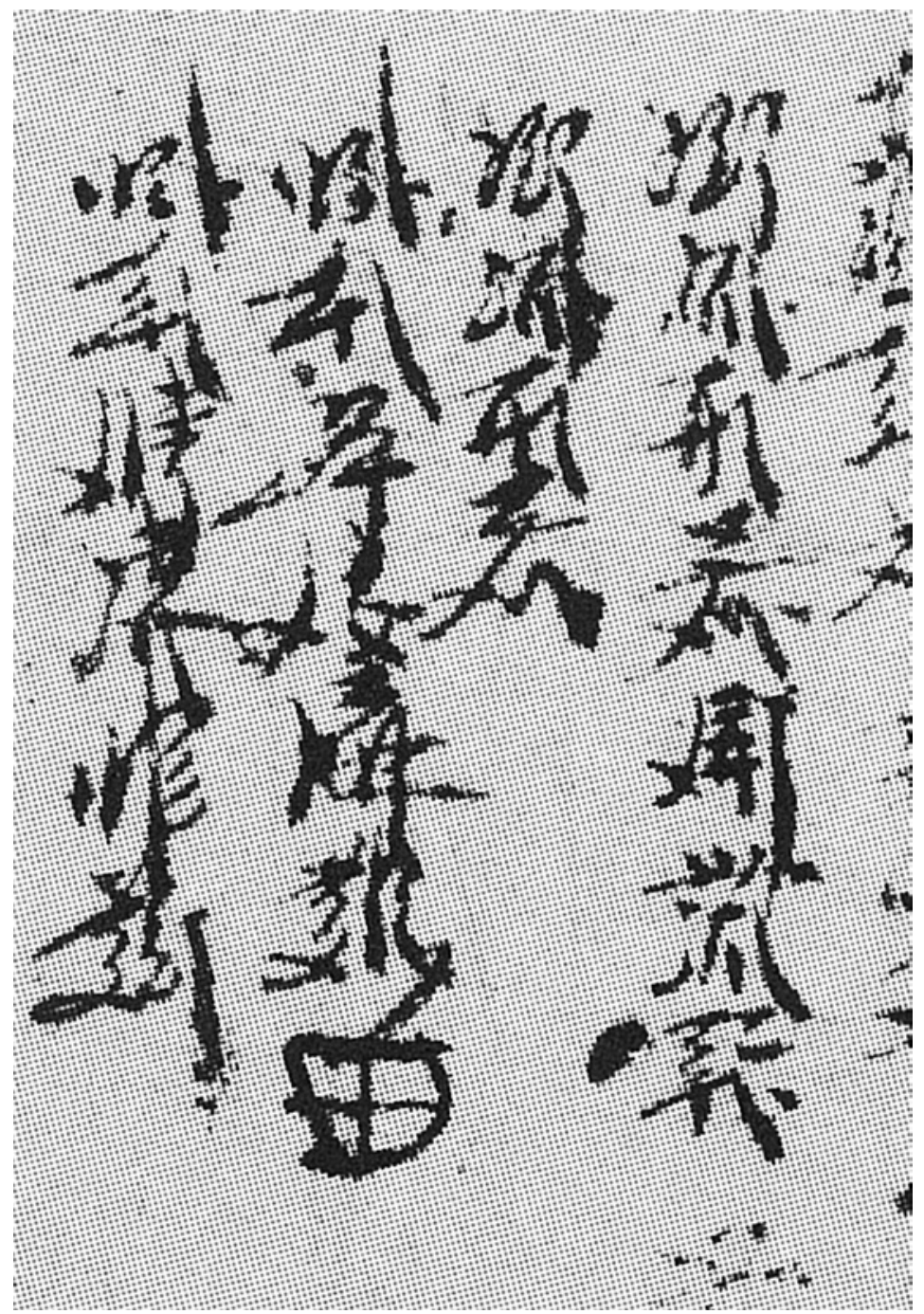

FIGURE 139 Инв. No. 4696-3(1): Shen year of Guangding (1212) account of grain loan (witness: Liang Laofangbao) 


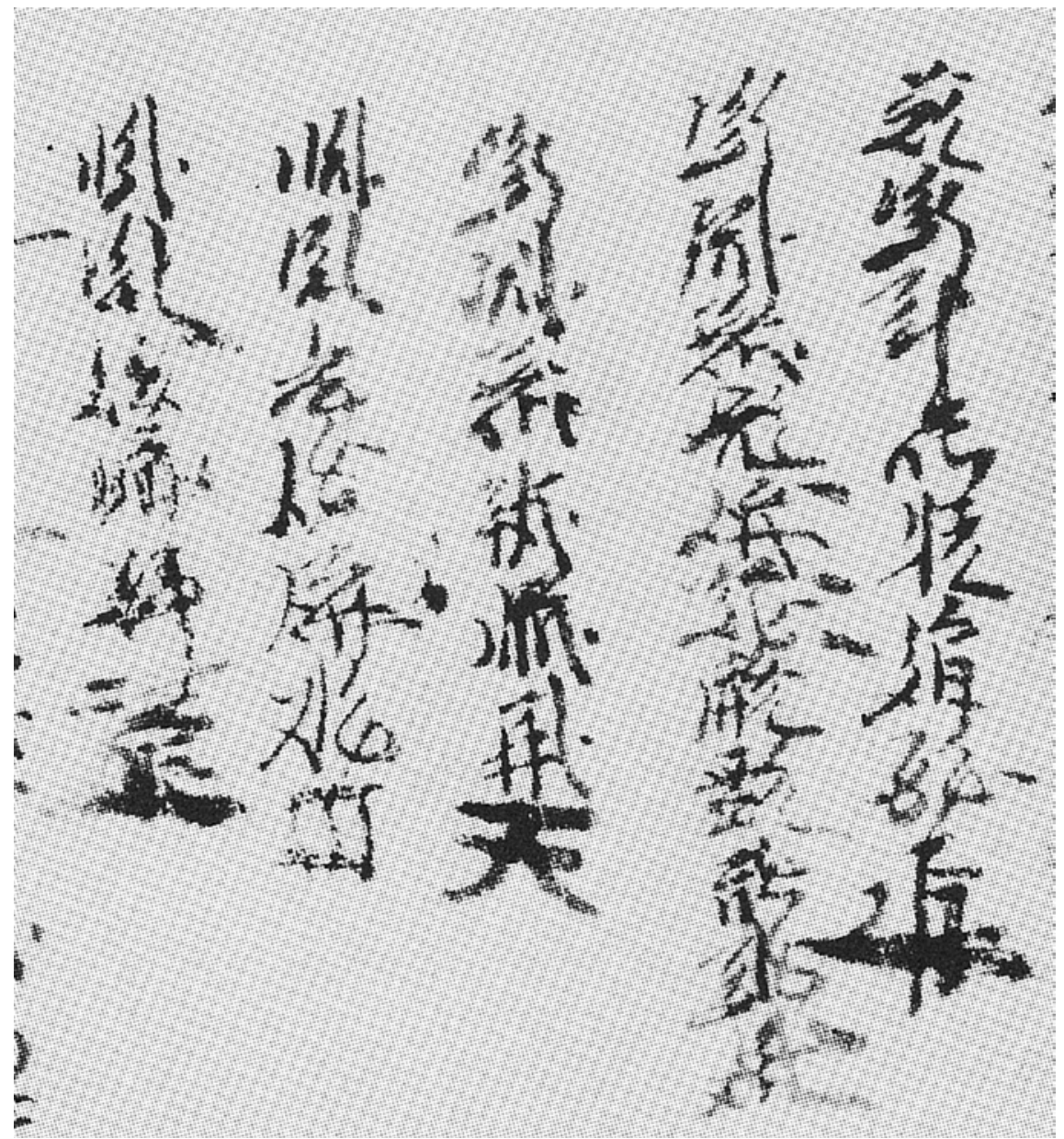

FIGURE 140 Инв. No. 4696-3(5): Shen year of Guangding (1212) account of grain loan (witness: Liang Laofangbao)

Liang "Treasure of the Old House" served as a witness to (2) (6) (7) (8) (9) (16) (17) (18) (19) (35) and altogether more than a dozen contracts of grain loans. Likewise, the witness Pingshang "Force of the Mountain" in Инв. No. 4696-733(1) served as a witness to three grain loans, contracts (2) (6) and (15). There was a significant legal distinction between the stamps and signatures of a witness and those of the co-borrowers. The witnesses served no more than to bear witness to the existence of such a legal arrangement, and therefore, they assume no joint liability at all. Whereas a co-Contract Party by all means also witnessed the transaction between the creditor and the debtor, but he had to 
guarantee the enforcement of terms therein contained by his own financial resources, if needed be.

\subsubsection{Signing and Stamping}

The signatures and stamps of relevant parties of a contract were required for the document to obtain legal force by the acknowledgement of concerned parties in a given loan or transaction. Stamping and signing a contract has a long cultural and economic history that precedes Western Xia, and the Tanguts readily took over the legal format and ritual. Conventionally, the concerned parties either noted down certain characters or drew special symbols underneath their signatures in a given contract in order to certify their solemn approval of the terms. Signing and stamping were correlated, and in most cases, they co-existed. Given that, considering the vastly divergent levels of literacy in the use of contracts across times and territories, the signature part was often completed not by the party directly concerned in the transaction but by an agent or representative. The stamping of symbols was in many cases the only possible way to verify the credit and acknowledgement of the Contract Party. Oftentimes, the calligraphic styles of the handwriting in the signatures, as well as in them main text of the contract, of both the concerned and the related parties, appear nearly identical, suggesting that the same agent or representative might have not only issued the signatures on behalf of multiple persons, but also drafted the contract itself. This phenomenon speaks to the possible existence of a class of professional handwriters who were paid to process the entire contracting process for the parties involved. It is possible that in the local area, those capable of fluent and fluid use of Tangut drafted legal documents or even just signed their own names. They are, after all, in the minority.

There are two main ways to stamp: to draw symbols or to print the shape and length of one's own finger segments. Both types of stamps were found in the Khara-Khoto grain loan contracts.

The concerned parties may draw a special symbol of their own liking and marking below their signatures. To follow this practice with consistency, one would have to make a maximum effort to maintain the same shape and style in drawing the symbol over long stretches of time. Individuals designed their own symbols. All four Contract Parties and co-Contract Parties who signed the Инв. No. 4762-6(1), a grain loan contract officiated in Yin Year of Tianqing, signalled their approval of the legal document with symbolic stamps. The Tanguts designed symbolic stamps of various degrees of complexity on their contracts, ranging from simple strokes that resemble the Chinese characters '一, '工,' ' 天,' etc., to extremely composite and complex symbols that are difficult to 
replicate. But others did not bother to exercise their artistic ingenuity, resorting instead to a simple ink dot by their names. The stamp of the aforementioned Liang "Treasure of the Old Home" looks like a square, with a cross or a vertical stroke in the middle. Тhe Инв. No. 4696-3(1)-(1) features something like the Chinese character “田” (see image), and the stamps in (6) (8) (16) (17) and (18) resemble a horizontal version of the Chinese character "日." The symbol in contract No. (9) looks similar to a "井." No symbolic stamp is found, however, in contract $(7)$.

"Finger-painting," also referred to as "finger-modelling," is the practice of fitting one's finger to the space next to the signature on the contract, to mark the positions of one's fingertips and finger segments with ink. The resulted horizontal strokes mark the pledge of personal trust, approval, and acknowledgement of the signatory. In the Chinese tradition, men usually mark their left finger, whereas women often use their right hand. The most popular finger for this purpose is either the middle finger or the index finger. Either two or three segments are marked on the contract. Most Tangut contracts feature three segments of a finger in four strokes. Two witnesses provide an example of this type of finger-stamping in Инв. No. 4762-6(1), an account of grain loan in Yin Year of Tianqing.

It is worth noting that nearly all Khara-Khoto loan contracts lack the prints and signatures of the loaners - the creditors offering the loans-at the end of the contracts. This format, which may be referred to in modern legal terminology as a 'unilateral contract,' shows the superior socio-legal status of the lender in financial transactions. This is due to the fact that the contract was preserved under the dominion of the creditor. It is therefore assumed that he was under no necessary obligation to sign the document for it to maintain legal force. It was as recent as in the late imperial era of Tang Dynasty that creditors were legally obliged to sign their names at the end of contracts for them to obtain force. And with greater geographical and ethnographical proximity, it should be pointed out that contracts in 8th-9th century Western Regions do mention the creditors, which appear more often in the abstract persona moralis as "owner of wheat," "owner of millet," "owner of beans," and "cash owner" rather than by their personal names. Moving toward the 1oth century, however, the creditors seemed to no longer sign their titles or names. The lack of signature by the creditors in Tangut contracts reflects one outcome of this historical development in the medieval history of contracts. ${ }^{75}$ 


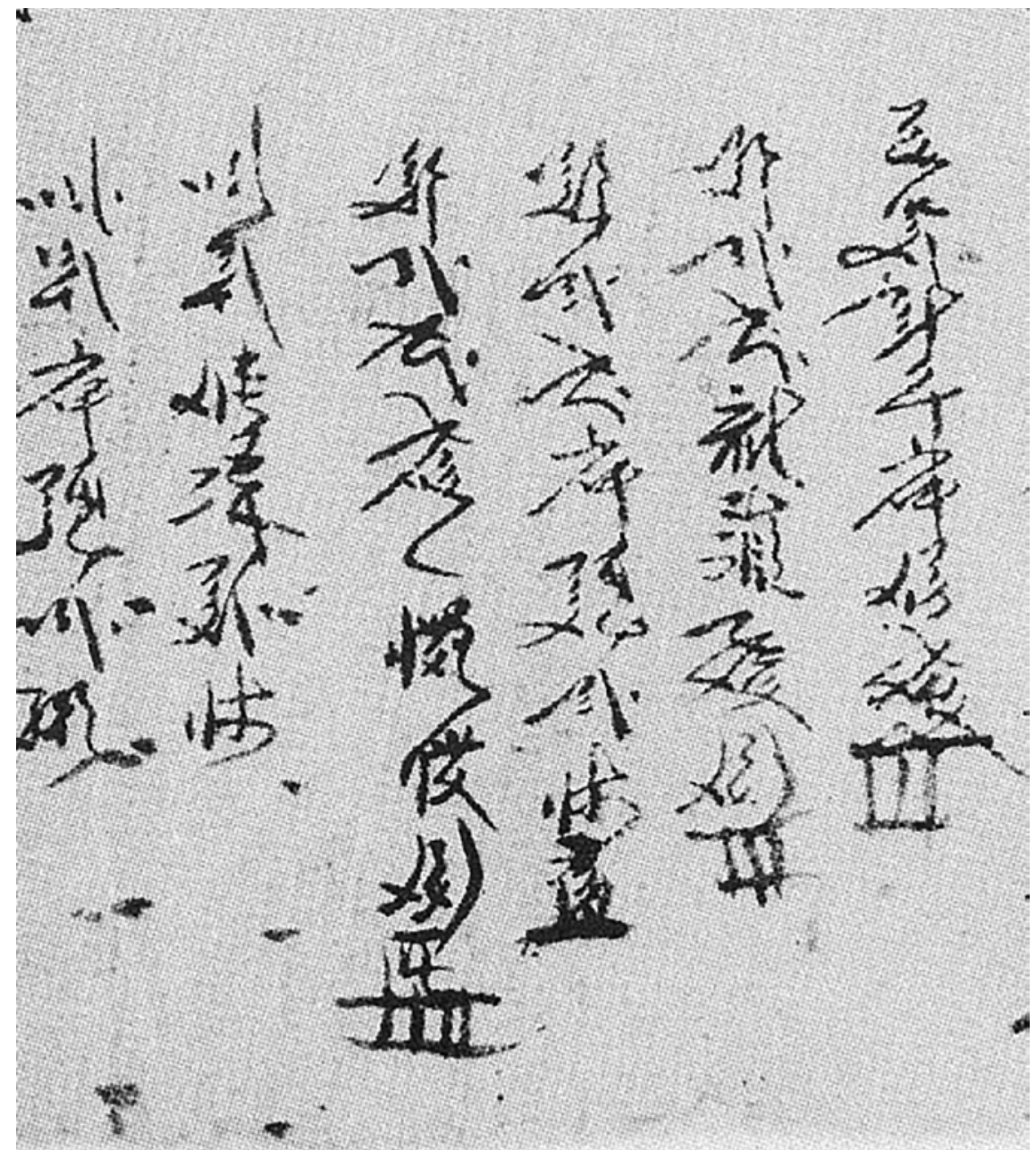

FIGURE 141 Инв. No. 4762-6(1): Yin year of Tianqing (1194) account of grain loan (first four: printed; last two: finger-stamped)

\subsubsection{Numerical Notation}

There existed parallel systems of numbers and numerical notations in ancient China. Numerical notations signify numbers by the special, spatial arrangement of tallies and tokens. Originally, these tallies were little sticks made of bamboo, wood, and bones, to denote a limited range of numbers. When tokens are rearranged to signify certain numbers, they may be placed horizontally or vertically. When the horizontal is the default, unit digits, hundreds, and tens of thousands are denoted by horizontal strokes; tens, thousands, and hundred-thousands are expressed in terms of vertical lines. When, however, 
the vertical is the default, the unit digits, hundreds, and tens of thousands are denoted by vertical strokes, whereas tens, thousands, and hundred-thousands are expressed in terms of horizontal strokes. Zero is always signified with the help of a blank space. The application of tokens to numerical denotations and calculations in a textual format is referred to as numerical notation.

Numerical notations use to specify the quantity of grain loans in Tangut contracts usually appear right above the signatures, near the end of the document. Numerical notations are applied to a document that already makes explicit reference to the types and quantities of the grains in prose, for the purpose of accuracy and security - that is, in order to forestall errors and confusions in the main text. This practice may come to better illumination when considered in the contexts of medieval Tangut palaeography. Given the prevalent use of the Tangut cursive script in drafting contracts, it often occurs that the simplified, interlinked, and free-flying strokes may challenge the eagle eyes of the Tanguts themselves. It is therefore much more expedient to adopt a different system of notation in order to check the numbers. Moreover, the numerical notations are symbolic, expressive, and intuitive. Even those inadequately versed in the Tangut scripts, of which there were many who resided in Tangut territories, would be able to grasp the numbers without much difficulties, and without entering into confusions and conflicts with the other parties.

Numerical notations in Xixia largely retained the logic of the system that prevailed in the Central Plains. Both rely on the combined use of horizontal and vertical strokes to denote certain numbers across different digits. A broad survey of Khara-Khoto contracts shows that the use of numerical notations is wide-ranging but not omnipresent, popular but not absolutely necessary. Furthermore, the symbolic and mathematical meanings of the horizontal and vertical strokes are not always consistent. The formula could even vary according to the habits of the loaners themselves.

One horizontal stroke "- " may signify 1 dan, and 2 strokes 2 dan, then one vertical stroke " | " meaning 1 dou and 2 strokes 2 dou; 10 dan may be denoted by the symbol " + ". In the manuscript Инв. No. 4783-7(2), for example, 6 horizontal lines "-" are found under a cross, " + " - that is, 16 dan. Then next to it we see 7 lines under 1 cross, which would be 17 dan. In Инв. No. 4596(5), two vertical strokes " | " are found under three "—" in the amount of 3 dan 2 dou.

Some contracts have 10 dan denoted by a large horizontal stroke, whereas a simple vertical stroke signifies 1 dan. A short horizontal stroke? That would be 1 dou. This is the case in the manuscript Инв. No. 5949-27 (1) (2), where “- " means 11 dan. A vertical line on the left and 5 short horizontal strokes on the right would add up to 1 dan and 5 dou.

Likewise, there are two distinct ways of denoting the number 5 . Some prefer simplifying 5 or more with one horizontal and one vertical strokes, rather 


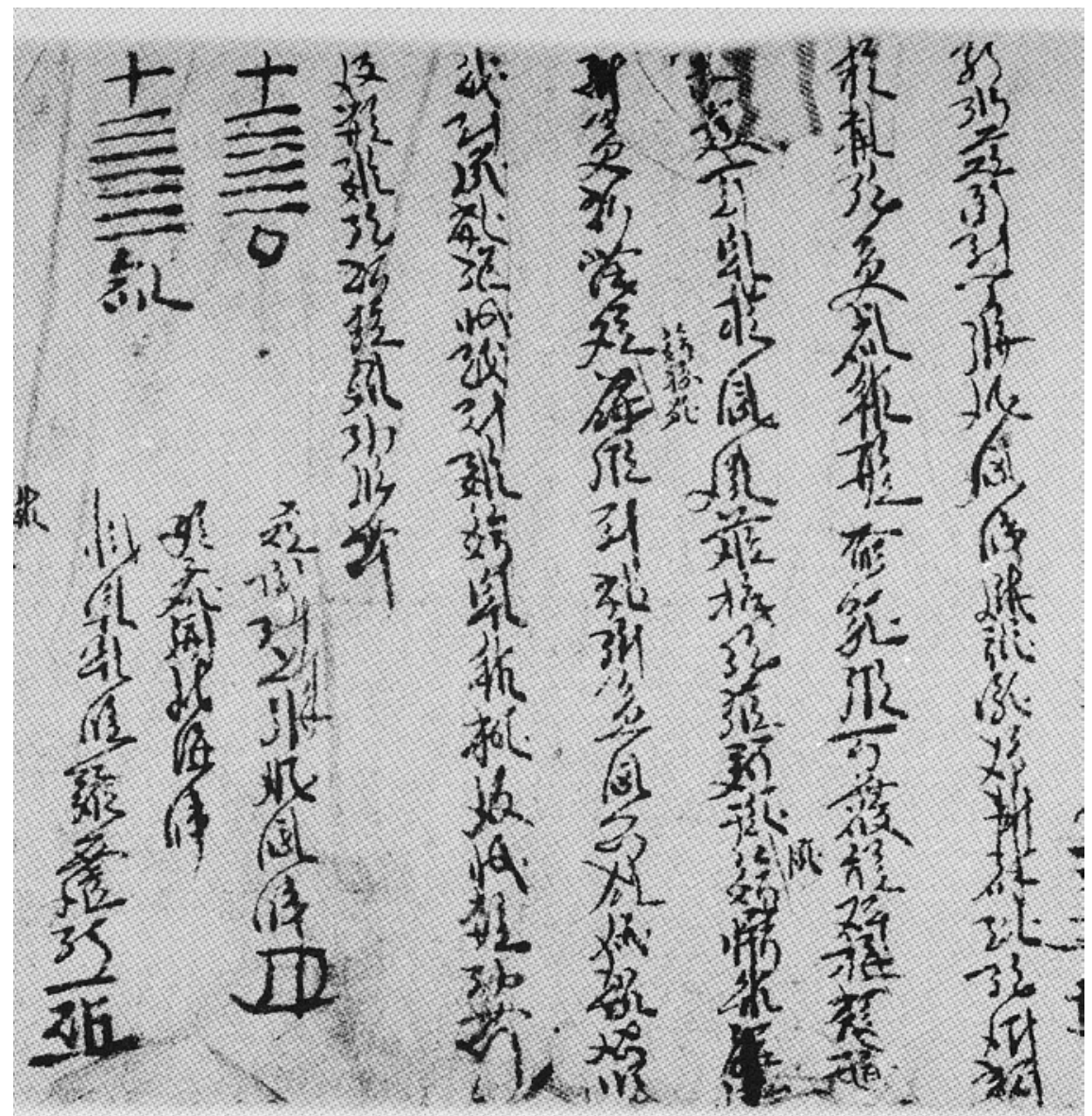

FIGURE 142 Инв. No. 4783-7(2): Account of grain loan (upper left corner: numerical notation)

than 5 consecutive strokes, horizontal or vertical. So, to indicate 6 with this 'quinary' system of horizontal strokes, one would draw $5 \quad 1=6$ : "T". In like manner, 7 would be " $₫$ ". Here, it is critical and necessary that the horizontal and vertical strokes are connected. Otherwise, $\top$ and $\pi$ would be confused with " 1 dan and 1 dou" and " 1 dan and 2 dou." For example, the parties in the contract Инв. No. 4696-1(1) negotiate for the loan of 8 dan, which is notated by 1 horizontal and 3 vertical strokes. In the Инв. No. 4696-1 (1) (2), there is a large horizontal line above 4 vertical strokes, signifying 9 dan; to the left are 3 short horizontal strokes, meaning $3 \mathrm{dou}$; further to the left are 5 even tinier vertical strokes, signifying 5 sheng. Altogether, the notation says 9 dan 3 dou 5 sheng. A line of Tangut notes in small font reads, "9 dan 3 dou 5 sheng wheat" confirms the accuracy of our reading. 


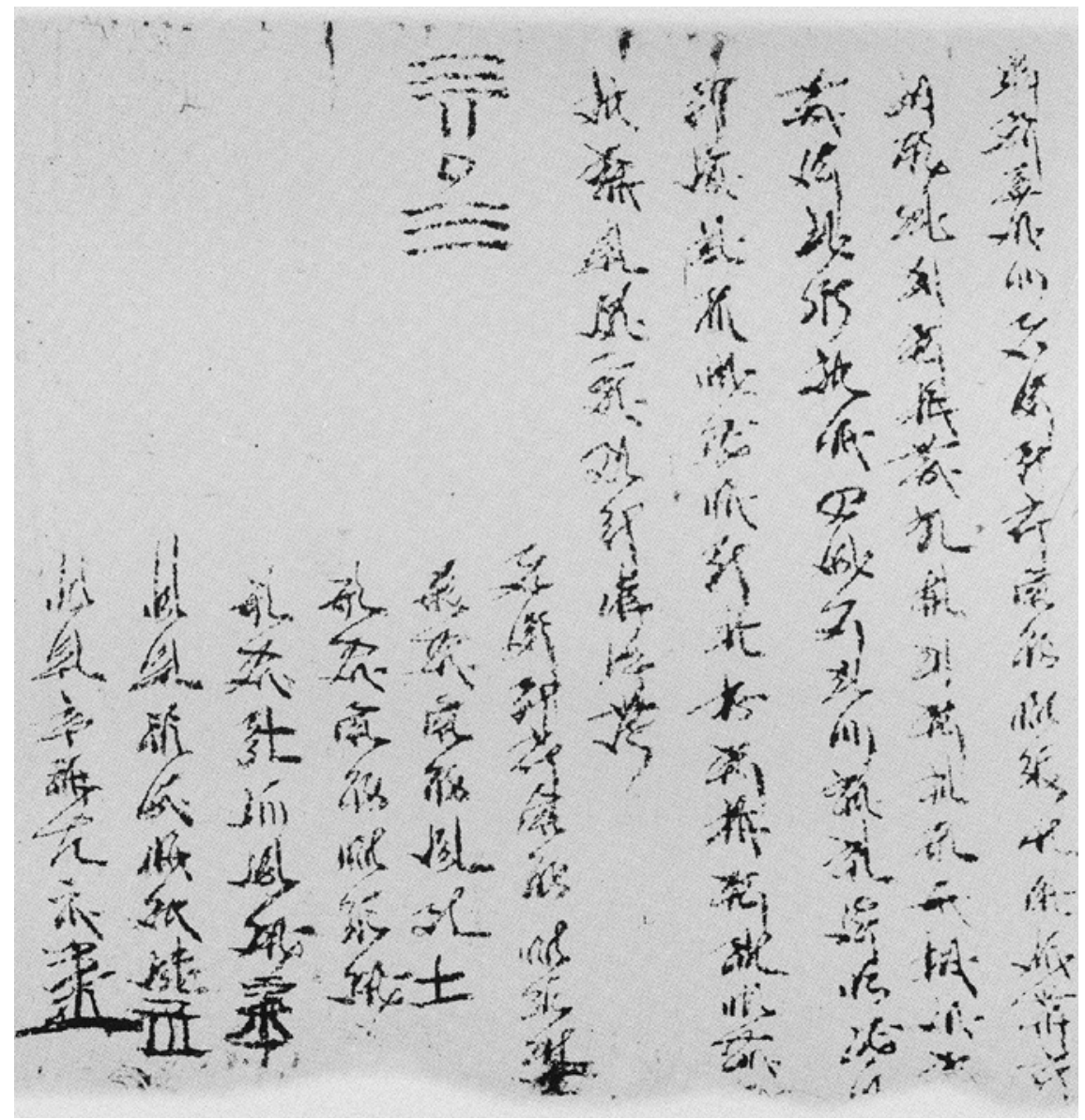

FIGURE 143 Инв. No. 4596(5): Chou year of Guangding (1217) account of grain loan (above: numerical notation)

The loan concerned in the document Инв. No. 5949-22 (2) (4) is in the amount of 27 dan of coarse grains: two large horizontal lines, and a compound symbol of one stroke with two connected vertical strokes $(5+2=7): "=\pi$ ".

Another 'quinary' notation is based on the use of a vertical stroke. So, a vertical plus a horizontal at its bottom: " $\perp$ " signifies 6 . To make it 7 , add one more horizontal stroke to the base of 5 : " $\perp$ ". One such example is the contract Инв. No. 4696-2(1), where by the borrower takes out a loan of coarse grains in

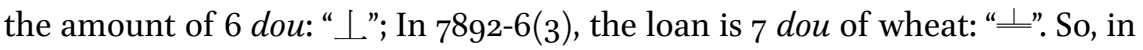
both of these cases, the vertical line is used to signal a set of $5 \mathrm{dou}$. Yet, some others prefer the old way: drawing 5 strokes one piled upon another. Іn Инв. No. 7741(3)-9, for example, the 7 dan of wheat appear as 7 vertical lines; in Инв. No. $5949-23(1)$, the 8 dou of coarse grains is notated by 8 vertical strokes; finally, 
in Инв. No. 5949-19(1), the 8 dan 5 dou are take the form of 8 horizontal over 5 vertical strokes.

Oftentimes, the notations are supplied with footnotes in Tangut characters that specify the types of grains concerned: wheat, assorted (coarse), barley, proso millet, and foxtail millet. Elsewhere, symbols are used to denote the types of grains: "o" is wheat/barley; where there is no symbol, coarse grains are implied. Toward the end of Инв. No. 4596-1(1), there is a marking of two horizontal strokes above a small circle-that is, a loan of 2 dan of wheat. In Инв. No. 4596-1(5), also near the end, there are 2 horizontal strokes at the top and 5 vertical strokes below; further down is also a small circle. This would be a loan of wheat in the amount of 2 dan and $5 \mathrm{dou}$. The additional two horizontal strokes indicate another 2 dan of coarse grains. Sometimes, instead of leaving no symbol to imply coarse grains, there would be a Tangut character for 'assorted.' In Инв. No. 4783-6(2), whereas the notation for 1 dan of wheat is a horizontal stroke above a small circle, that for 1 dan of coarse grains is a horizontal stroke above a Tangtu character 㛊 [dza]. Likewise, in Инв. No. 4783$7(2)$, there is a cross above, 6 horizontal lines in the middle, and a small circle at the bottom (16 dan of wheat), and a cross at the top, 7 horizontal strokes in the middle, and a Tangut character 政 [dza] at the bottom: a loan of coarse grains in the amount of 17 dan.

Some of the contract fragments have lost the main content altogether, but it is still possible to take a peek at the ending. In these cases, the numerical notation reveals the quantity of the grain loan, even if the number indicated in the main text is missing. For example, in the manuscript Инв. No. 5949/31, a remnant end-page of the original contract, we find the following numerical notation: four horizontal lines above 2 vertical strokes, and right to the two vertical lines, there is a small horizontal stroke; below which is found a tiny circle; further below is a cross + , followed by 4 vertical strokes. From these symbols we know that this particular loan consists of 4 dan 2 dou 1 sheng wheat, and 1o dan 4 dou coarse grains.

The above discussions in multiple parts reveal the richness, diversity, and various levels of complexity in the corpus of Khara-Khoto grain loan contracts. Accounts of large-quantity loans, or those that involve complex terms of loans and relationships, are usually written in a complete and thorough format.

Several relevant legislations in the Laws of Heavenly Prosperity provide the juridical principles and legal basis for contract-making under Tangut laws. The excavation of these contracts provides original historical sources that are never known to historians before. These varied materials are also remarkable for their stark level of details in the procedures of offering and taking grain loans in Western Xia. With these invaluable and irreplaceable sources, it is altogether possible to repaint a colourful and blow-by-blow canvas of grain-loaning 


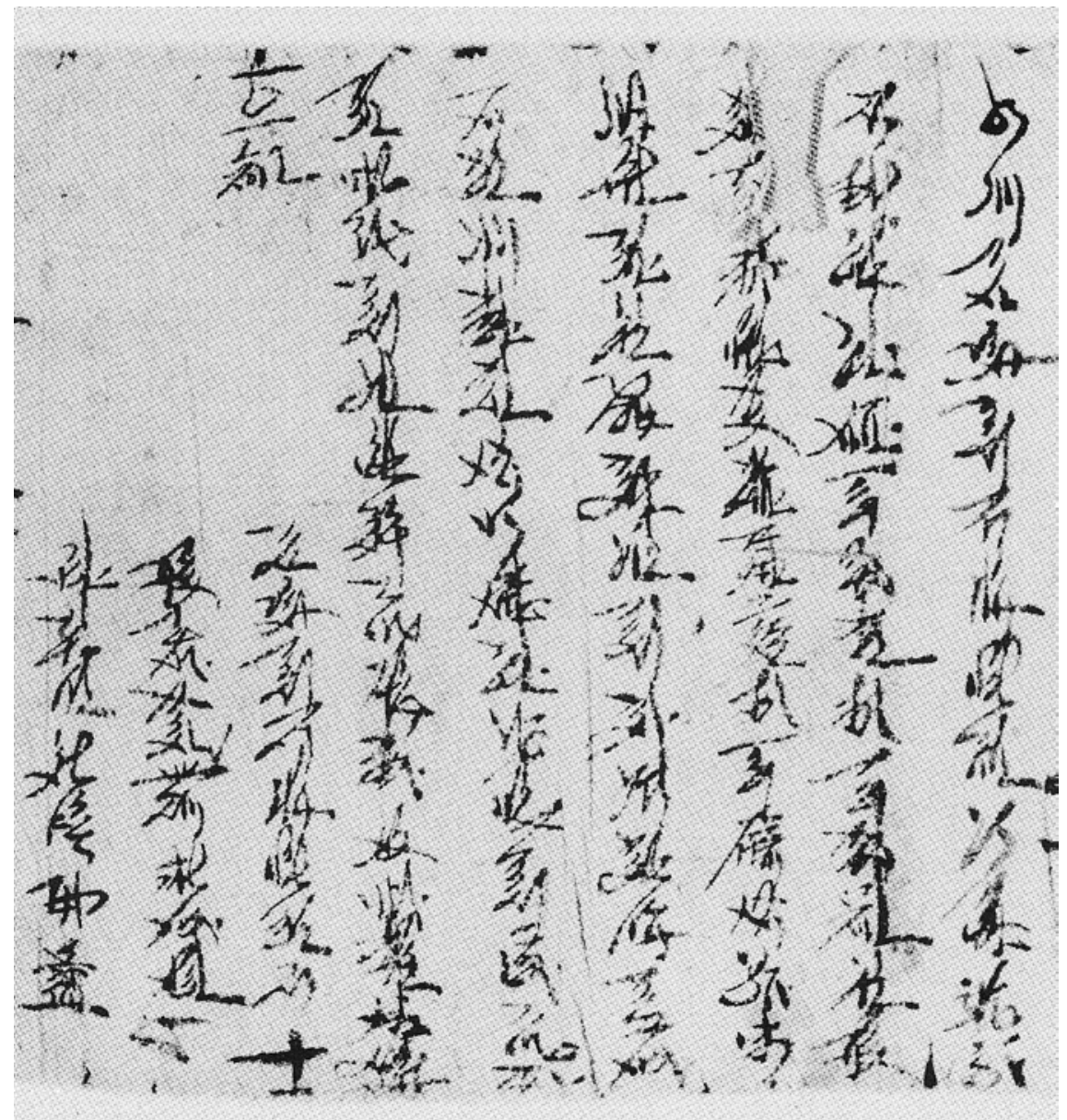

FIGURE 144 Инв. No. 4783-6(2): Wu year of Guangding (1222) account of grain loan

scenes at the base level of the Tangut society. A comparative and connective reading of the contracts and the law code would gain a deeply penetrating insight into the residential life, economic conditions, agricultural productions, living standards, and wealth inequality in Tangut households, neighborhoods, and communities.

2.1.11 Conclusive Remarks on Tangut Grain Loan Contracts

A comprehensive survey of the Tangut accounts of grain loan unearthed in Khara-Khoto yields the following conclusions:

1. The vast plurality of Khara-Khoto contracts are grain loan accounts, numbering up to more than 110 registers and 300 pieces, about $2 / 3$ of the total 
corpus of Tangut contracts. These documents are as diverse as numerous, more so than grain loan contracts found in the Dunhuang.

2. Most Tangut loan contracts are written in a set format. Oftentimes, multiple contracts are written on the same piece of paper. Longer scrolls contain as many as dozens of contracts, which form a chain of interlinked accounts. Single-page accounts of grain loan are, in contrast, much fewer and rarer.

3. Grain loan accounts do not record the reasons for loaning. Most of the loaning takes place in the spring, a gap period between two harvests. Those who apply for loans are Dangxiang Tanguts, but also Han Chinese, as well as serfs and semi-slaves such as shijun and nupu. Those who offer the loans are either landlords with a huge surplus or, indeed, religious establishments at Buddhist temples.

4. The Tanguts loaned grains with interests, and the rate is oftentimes exorbitant. The loan arrangement and the setting of interest rates are based on the 'principle'- the base number of grains. There are roughly three types of loans: daily interest, monthly interest, and interest on total sum. Whichever type it might be, the interest rate usually reaches $50 \%$, and even $80 \%$ and $100 \%$ in the matter of 3-4 months. Some even cross the ceiling of 'multiple-times interest' set by the regulatory agencies of the Tangut government. These contracts are living testimonies to the many and grave financial exploitations of the Tangut poor at the hands of 'loan sharks.'

5. Nearly all contracts set out terms of penalties for borrowers unable to return the principle and interests in due time. These terms are secured and guaranteed by prints of finger lengths and personal signatures. These materials provide evidence on the guarantee of loaner's legal rights.

6. A certain number of grain loan contracts employ not only verbal language to denote the types and quantities of the grains, but also a system of numeral notation at the end of the contract. From a lateral, case-study perspective, this evidence points to the fact that the contracts written in Tangut, by an ethnic people, inherit the system of numerical calculation and notation. It again speaks to the cultural transfer and influence of the Central Plains on Western Xia.

\subsection{Monetary Loans}

Monetary loans are rare finds amongst Tangut loan accounts and contracts. But the Khara-Khoto manuscript Инв. No. 986-1 contains a set of two contracts of this type. Dated to the Gengchen, Tenth Year of Guangding (1220) and the Si year (1221), it is a Tangut monetary loan document handwritten on 


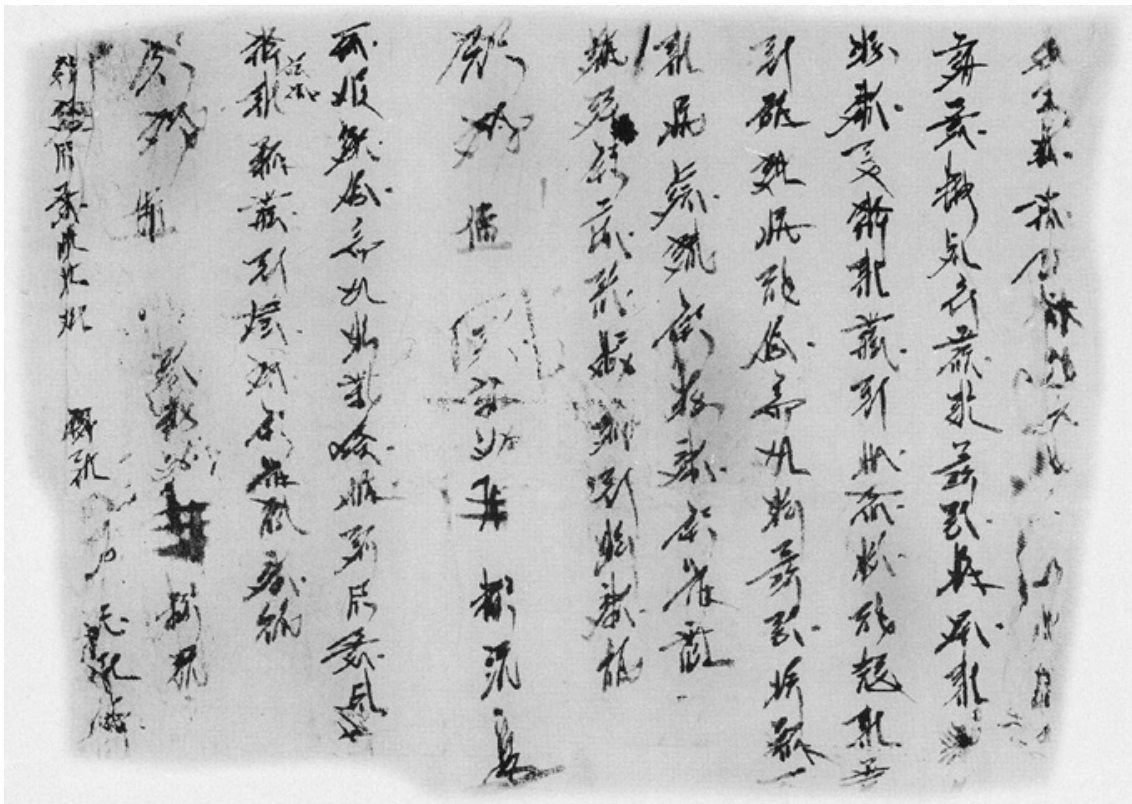

FIGURE 145 Инв. No. 986-1: Gengchen 1oth year of Guangding (1220) contract of monetary loan

a $22.2 \times 31.2 \mathrm{~cm}$ hemp paper fragment, with 11 lines of Tangut in the cursive script. It begins with the year: Gengchen, Tenth Year of Guangding (1220); then in line 8 , "7th day of the 1st month in the Si Year" (1221). ${ }^{76}$

Two contracts are found in the page fragments. The lower sections are damaged and some words are lost. The contracts are written in the cursive, some of which are blurry and illegible. But from the words that do lend themselves to interpretation, we know that in the first contract, someone obtains a cash loan in the amount of 7 guan and 10 rolls of materials, on a mortgage of 200 pieces of some other goods, in the Gengchen Tenth Year of Guangding. Repayment is due on the 1oth day of the 1oth month. Any party which reneges on the agreement is punished according to the terms set in the contract. The document ends with signatures and stamps. The second contract is simpler. It records a loan of ?guan and 500 mace on the 1oth day of the 1st month in the Si Year (the following year since the previous contract). Although both contracts are short of key information and much remains unknown, they more than suffice to show that the Tanguts in Khara-Khoto did practice monetary loans.

$7^{6} \quad$ Russian Collection of Khara-Khoto Manuscripts 12, p. 156. 


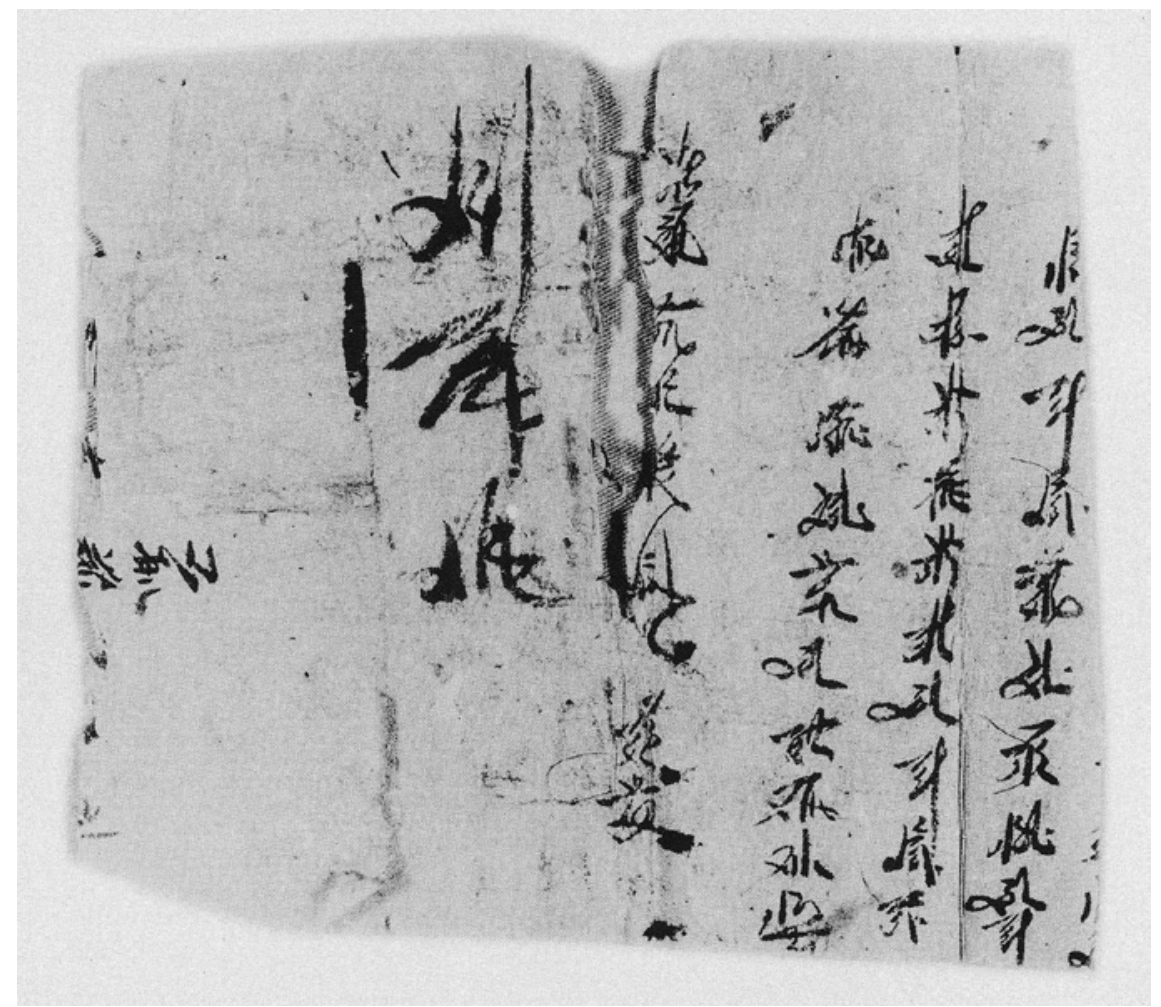

FIGURE 146 Инв. No. 1523-23: Chen year of Qianyou. Document of monetary loan

Another document of monetary loan is the manuscript Инв. No.1523-23, handwritten in 5 lines of cursive Tangut on a $23.1 \times 25.8 \mathrm{~cm}$ cover-layering paper, which is patched together from two pieces of papers. In line 4, the text indicates the time of the contract as "the last month in the Chen Year of Qianyou" $\left(1172\right.$, or 1973, or 1185). ${ }^{77}$ There are stamps and signatures.

This document is probably not a contract in the strict sense, but it surely testifies to the practice of monetary loans. For although much information is lost, we still find this line: "overdue payment doubles, each 1 guan will be repaid in 2 guan." So, the Tanguts must have loaned and borrowed cash, not just goods and grains.

In the Инв. No. 1523-24 cash loan account, there is a reference to "One item: on the 5th day of the 6th month in the Renchen Third Year of Qianyou (1172), Contract Party Dashi?? First himself borrows 700 guan of cash, at the interest rate of 8 wen per string of cash per day. The loan is due in 100 days, upon which 
time both the principle and the interests are to be repaid in full." This, too, is evidence that the Tanguts practiced monetary loans in cash.

\subsection{MaterialLoans}

Loans of objects and materials are also rare amongst Khara-Khoto documents. There is the manuscript Инв. No. 955, a material loan contract dated to the $\mathrm{Si}$ Year of Guangding (1221). It is a single-page contract fragment with 9 lines of cursive Tangut handwritten on a $19.9 \times 23.3 \mathrm{~cm}$ hemp paper. It begins with the year, and ends with stamps and signatures. ${ }^{78}$

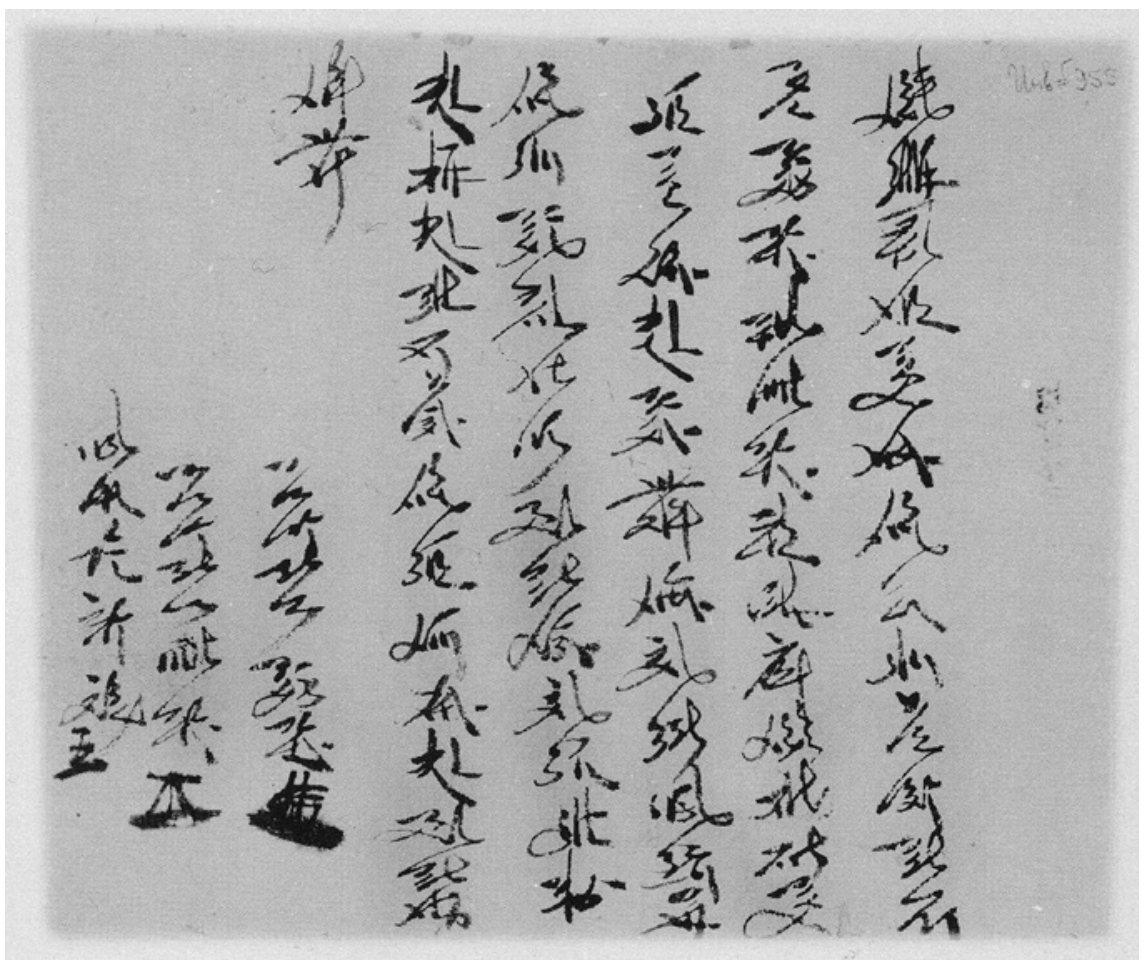

FIGURE 147 Инв. No. 955: Si year of Guangding (1221) contract of loaning goods

Translation:

On the 5 th day of the 7 th month, in the Si Year of Guangding, Contract Party Li??, ??? et al., presently from 倠琉㸚 [ljow ne_w lji-.]

Borrow 7700 rolls [kji], due in the same month

78 Russian Collection of Khara-Khoto Manuscripts 12, p. 146. 
By the $15^{\text {th }}$ day, to be repaid. If overdue, the [kji]

Has to be doubled in repayment, i.e. 15400 rolls. Own

Hearts Willing.

Contract Party: ?? (stamp)

Co-Contract Party: ?? (stamp)

Witness: ??? (stamp)

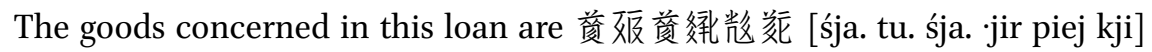

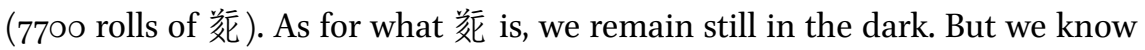
that the character pronounces as [kji], and it is a type of good counted by the unit of 改 [piej] (roll). The contract does not make mention of any interest, only insists on timely return of the goods. A possible reason is that this type of good is not consumable or easily liable to loss or damage. Still, overdue return is severely punished: the borrower will have to return twice the quantity in the loan.

\section{3}

\section{Transaction Contracts}

As a form of economic activity, sell and purchase is central to commerce. Therefore, sale contracts are crucial to private law, past and present. As a basic type of contract, it is often also the most formal, detailed, and well-crafted. For these and other reasons, Khara-Khoto sell and purchase contracts are crucial primary sources to studies of the Tangut economy.

\subsection{Land Sales}

In an agriculture-based economy, it is no surprise that the selling and buying of farmland is the single most important economic activity in medieval Western Xia. A batch of Tangut land sale contracts found in Khara-Khoto have furnished us with the necessary primary sources to understand the way farmland was exchanged in the historical Tangut economy.

Back in 1972, Soviet Tangutologist Evgenij Ivanovich Kychanov identified and translated amongst the Khara-Khoto manuscripts in Russia a piece of land sale contract written in the running style, dated to the Gengyin, 22nd Year of Heavenly Prosperity (1170 AD)..$^{79}$ This is the first time ever a Tangut social document is openly published, an event of great significance to the study of Tangut commerce and agriculture, and even to answering geological question

79 Кычанов, Е.И. Тангутский документ 117ог. о продаже земли, "Письменные памятника Востока.Ежгодник. 1971," М., 1974, pp. 196-2о3. 
of land and soil in the area. This contract is complete, with full information on the date, main parties of the transaction, size of the land and the fixtures that come with it, the seller, price (in terms of livestocks), terms of guarantee, penalties for the breach of the contract, the four boundaries of the land, and finally, the stamps and signatures of the seller, guarantor, and the witness. As the only known piece of land sale contract at the time, its publication caught the attention of Tangutologists worldwide. Given the difficulty of the running script, experts have continued to probe into the document. ${ }^{80}$

In preparation for the publication of the Russian Collection of Khara-Khoto Manuscripts, we have found another 11 pieces of farmland sale contracts in the pile of newly discovered Khara-Khoto social documents. Along with the one studied by Kychanov, there are now a total of 12 Tangut land sale contracts. These contracts from 700-800 years ago are authentic primary sources on land exchange in Tangut Khara-Khoto. There are only a very few incomplete land sale contracts from the Song, Liao, and Jin Dynasties. Whereas Western Xia alone supplies a whole batch of contracts rich in data and information. These documents are the best materials to rely on in the historical study of the Tangut economy.

\subsubsection{Translation and Interpretation of Land Sale Contracts}

Some Khara-Khoto land sale contracts are single-page documents, others are found in multi-document series. The Gengyin, 22nd year of Tiansheng land sale contract Инв. No. 5010 mentioned just now is an example of a single-page document. 19 lines of Tangut in the cursive script are handwritten on a $22.5 \times 49.6$ hemp paper. ${ }^{81}$ Other single contracts include the Инв. No. 4199: Liang's land and house sale contract on the 16th day of the 6th month in the Bingchen Year (1196); Инв. No. 4193: Maze's land sale contract on the $5^{\text {th }}$ day of the 1st month in Wuwu, the 5 th year of Tianqing (1198); Инв. No. 4194: 䘞萲 溶倠 [lew śji thow pha ]'s land and house sale contract in the Gengshen Year of Heavenly Celebration (1200). These three contracts are, in the same order,

80 Huang, Zhenhua. “Xixia Tiansheng Ershiernian Maidi Wenqi Kaoshi” [西夏天盛二十 二年賣地文契考釋]: “A study of the land sale contract in the 22nd year of Tiansheng” in Xixiashi Lunwenji [西夏史論文集]: Collection of Essays on Tangut History. Yinchuan: Ningxia People's Press, 1984, pp. 313-319; Chen Bingying.

Xixia Wenwu Yanjiu [西夏文物研究]: A Study of Tangut Cultural Relics. Yinchuan: Ningxia People's Press, 1985, pp. 275-279. Shi Jinbo, 2007, pp. 72-73; Nomura, Hiroshi (松泽博, 野村博). “Wuwei Xixia Bowuguan cang Haimudong Chutu Xixiawen Qiyue Wenshu” [武威西夏博物館藏亥母洞出土西夏文契約文書] in Dongyang Shiyuan [東洋史苑] Issue 75, July 2010, pp. 21-64.

81 Russian Collection of Khara-Khoto Manuscripts, vol. 14, see images 1 and No. 2. 
handwritten in cursive Tangut on a $23.5 \times 45 \mathrm{~cm}$ hemp paper; handwritten in the cursive style on a $23.2 \times 43.1 \mathrm{~cm}$ hemp paper; handwritten in the cursive on a $22.9 \times 57.1 \mathrm{~cm}$ hemp paper. ${ }^{82}$ Later, a new batch of contracts has been discovered: the Инв. No. 5124 long scroll of contracts, wherein are found 23 contracts dated from the end of the 1st month to the early and month in the Yin year of Heavenly Celebration (1194). Amongst them are contracts of not only land sale, but also land lease, livestock sale, livestock loan, as well as grain loan accounts. The long scroll is patched horizontally from multiple pages, in a total of three segments. The scroll is $20.5 \mathrm{~cm}$ in length, and $55,175,26 \mathrm{o} \mathrm{cm}$ wide, respectively. So, if we count the 8 land sale contracts in the long scroll, ${ }^{83}$ adding it to the 4 enumerated above, we could say that so far, there are a total of 12 Tangut land sale contracts. Except for the earliest-found contract, which is written in the running script, all other contracts are written in the even less decipherable cursive style. In the light of the equal scarcity and significance of Tangut land sale contracts, I shall present a translation of each of the 12 contracts below, in the order of time.

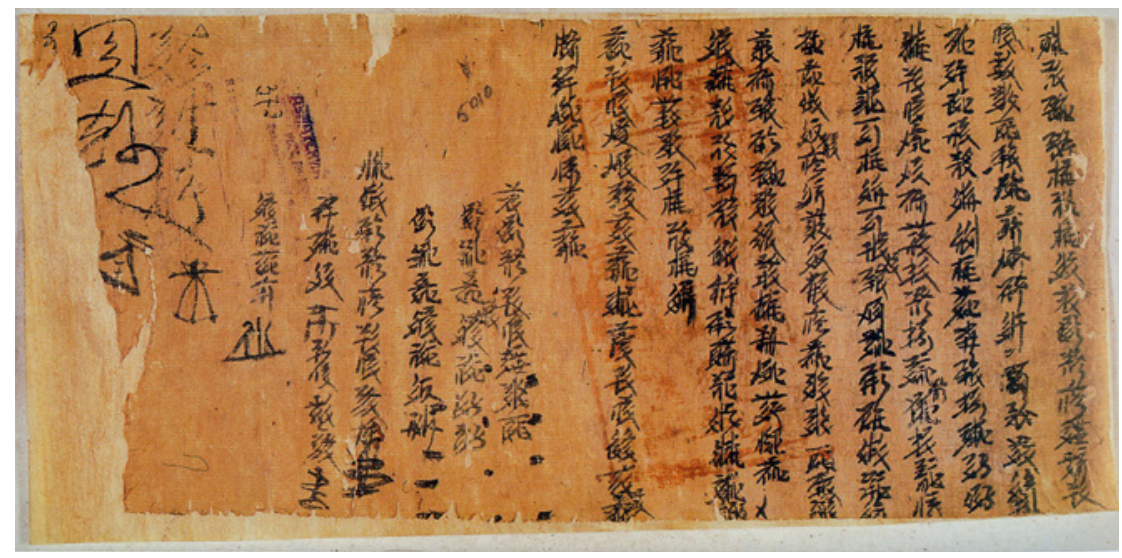

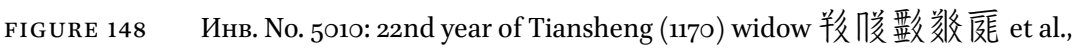
contract of land sale

$82 \quad$ Russian Collection of Khara-Khoto Manuscripts 13, pp. 199, 194.

83 Russian Collection of Khara-Khoto Manuscripts 14, pp. 13-22. The contract scroll is patched horizontally into one manuscript from multiple pieces of paper. As the scroll ages over time, the parts begin to fall off. A total of 18 photographs were taken on this set of manuscripts, which are reorganised into three sections, in the order of content and chronology. Part I: 2 and 3; Part II (loss of content at the beginning): 1, 6 left, 7, 8, 9, 10, 11 left; Part III: 4, 5,6 right, 11 right, $12,15,13,14,16,17,18$. 


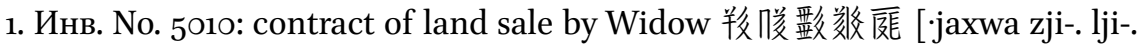
śio] in the 22nd year of Heavenly Celebration (1170), a single-page contract with 19 lines of cursive Tangut on a $22 \times 48.5 \mathrm{~cm}$ hemp paper, with stamp, signature, and red seal. ${ }^{84}$

Translation:

In the Gengyin, 22nd year of Heavenly Prosperity, ${ }^{85}$ Contract Party Widow 羓 $[\cdot$ ja $]$ -

羓数庭 [xwa zji-. lji-.śio] et al., presently has her own ripe/unripe land for 2 dan of seeds, $1^{-}$

patch, ${ }^{86}$ along with a yard \& 3 thatched cottages, 2 trees altogether voluntarily sold to 羓朘椂挍 [·jaxwa mji-_tshja] at the price hereupon agreed: 2 full-teethed camels,

1 two-teethed, ${ }^{87} 1$ old ox- 4 in total. ${ }^{88}$ Hereafter, on this land 89

Let there be no dispute. ${ }^{90}$ In case of a dispute, let Baoyin be responsible. ${ }^{91}$ Let any reneging party ${ }^{92}$ not only ${ }^{93}$ be punished according to the Laws and Orders, ${ }^{94}$

$84 \quad$ Russian Collection of Khara-Khoto Manuscripts, vol. 14.

85 Tiansheng (Heavenly Prosperity) is an era name of the Renzong Emperor of Western Xia. It lasted for 21 years (1149-1169). In the Gengyin, 22nd year of Heavenly Prosperity (1170), the title is changed to Qianyou (Heavenly Blessing). In the 8th month of that year, Renzong emperor arrests and executes the powerful court official Ren Dejing (任得敬), upon which occasion he changed the era name. If so, then the contract should have been drafted and signed before the eighth month of that year.

86 In the manuscript, there are two vertical dots before 辡 [dźja_] (dan). The character preceding dan is likely to be a number, i.e. two. Land fit to sow 2 dan of seeds also matches the " $22 m u$ " that comes later in the text.

87 椄婙 [nji-_dzjiw] lit. two there are (vertical existence), i.e. a livestock is at a certain age when it has vertically grown two teeth.

88 The full price is the total of the four large livestocks.

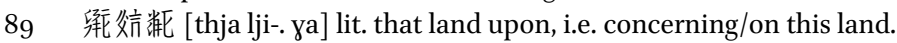

90 仮嫒 [lja_bej] lit. mouth entangled, i.e. dispute, controversy.

91 渐 [kwa ], a loanword from the Chinese 管, to manage and oversee, to bear the responsibility.

92 䂦核 [da. lhej] lit. speech change, i.e. to eat one's words, to alter opinions, to renege on promises.

93 纸花 [mji dźjij] lit. not purely, not only, esp. at the conjunction of two clauses.

94 㷋數 [kie dzji-_] lit. rules and orders; laws and orders. It refers to Tangut laws in general, including the Revised Laws of Heavenly Prosperity, etc. 
But also, according to the laws, ${ }^{95}$ pay a penalty fee of 30 dan of wheat, according to the circumstances ${ }^{96}$ and the document. ${ }^{97}$

Down the administrative hall there are $22 \mathrm{mu}$ of land.

To the north it borders the land of Yehe 'the prosperous Huihu'; to the east and south, it borders with 䍩朘 [-jaxwa]??

To the west it borders Liang 'Mount Weiming'

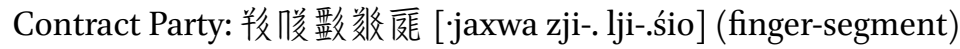

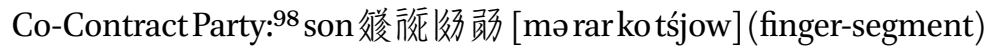

Co-Contract Party: 啳沿坂刘 [mərar lja_bju] (finger-segment)

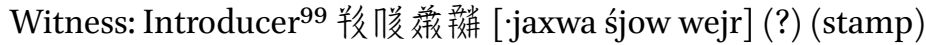

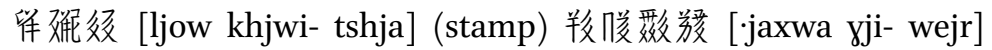

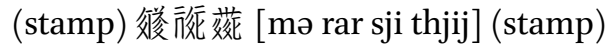

Tax paid (stamp)

8 ? (stamp) $)^{100}$

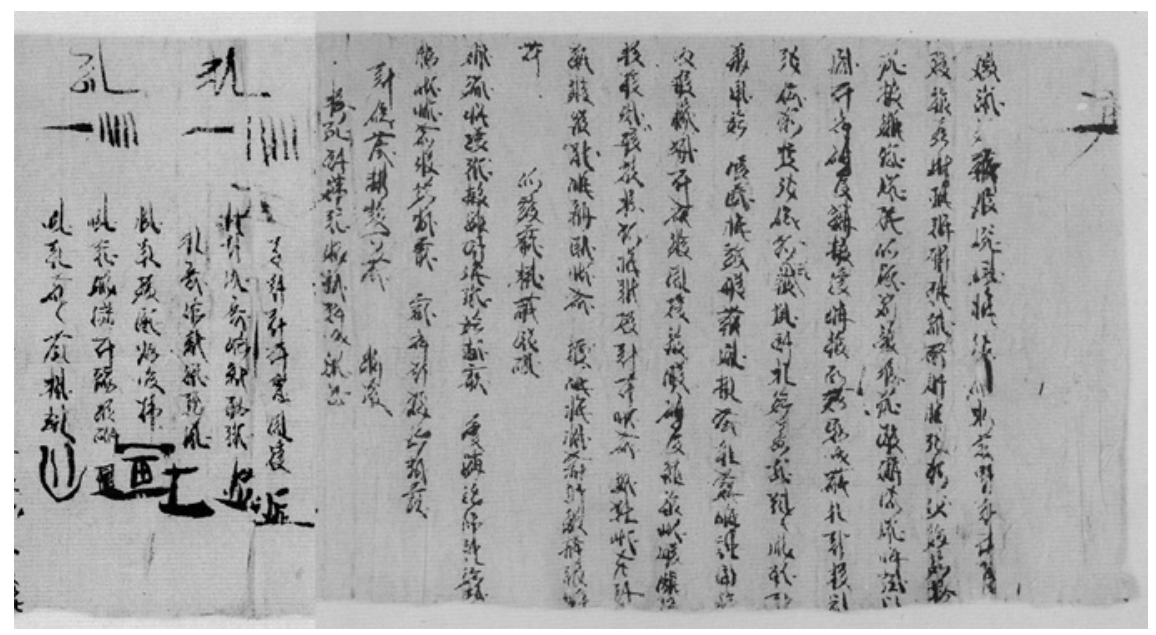

FIGURE 149 Инв. No. 5124-2: 24th day of 1st month in Yin year of Tianqing (1194) contract of land sale by 蓄微楛

95 㣪准 [know bju] lit. office/government accord, i.e. in accordance with the rules and laws set by the government.

96 信醳 [da. kwər] lit. a body of speech, i.e. conditions and circumstances.

97 瓶嫩 [lji. lu.] lit. to fall into the rod/stick, i.e. to formulate a text: a textual receipt, a contract.

98 渗部范 [dźiow sa dźjwi-] lit. the document receiving-one, i.e. a co-seller of the land, a co-Contract Party who also partake in the transaction and shares liability.

99 假并落应 [da. wji mjijr] lit. speech-making one, i.e. an agent, introducer, negotiator between the selling and purchasing parties, who also serves as a witness to the signing of the contract.

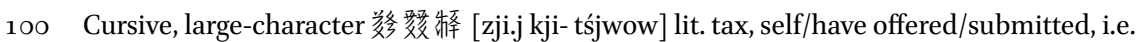
tax already paid. 


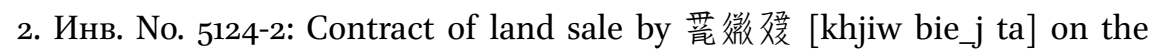
24th day of the 1st month in the Yin Year Heavenly Celebration (1194), found in the Contract scroll Инв. No. 5124-2, in 20 lines of cursive Tangut, signatures, and stamps. ${ }^{101}$

Translation:

On the 24th day of the 1st month in the jia $^{102}$ yin year of Heavenly Prosperity, Contract Party 竜微 [khjiw bie_j] -

嫒 [ta] (et al.) has his own ripe/unripe land fit to sow 20 dan of seeds, which borders the left canal at the end of the canal,

one patch, along with a full set of house and yard, including a 4-cabin house, etc. altogether voluntarily sold to Pudu Temple's

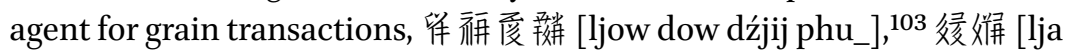
mja] et al., at the sale price, in coarse grains,

${ }_{15}$ dan, wheat 15 dan. The payment and land are exchanged, with no debt incurred.104

In case of any other attempts to mortgage or transfer the title, either publicly or privately, ${ }^{105}$ or if members of the same $c h a o^{106}$

Launch a dispute, ${ }^{107}$ let 微磅 [bie_j ta] et al. take responsibility; let no

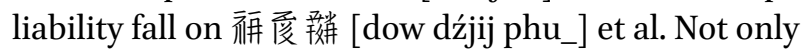

101 Russian Collection of Khara-Khoto Manuscripts 14, pp. 13-14.

102 The character 蓕 [de.j] (Jia) is resupplied to form the sexagenary combination, Jiayin, in the era of Tianqing. There are two years of Yin in the Tianqing era: Jiayin the first year, and renyin the thirteenth year. What remains of the illegible character suggests that it could only be Jia, as opposed to Ren.

103 TN: The name of this man has been transliterated into Chinese. Here, I present it in the Tangut original with a phonetic notation. A possible literal meaning of the name could be: "Liang the lush, evil god," which very much befits his profession.

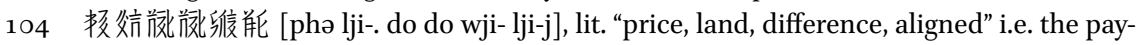
ment and the land are aligned in their values, and there remains no discrepancy. A comparison to the Chinese text of the same content yields a smoother translation: there is no debt incurred in either payment or land. That is, the payment is made, and the land is transferred, at the price that both sides have agreed upon.

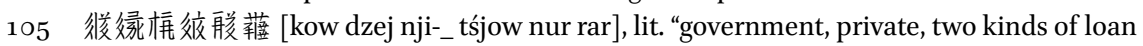
transfer," i.e. to transfer the title as a loan either through/to the government, or in private transactions. In Western Xia, loans, pawning, and mortgaging could be done either through the government or privately. The contract specifies that upon the completion of the contract, no other transfer either publicly or privately will be permitted.

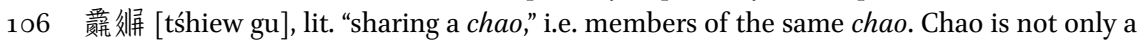
basic military unit in Western Xia, but also a socio-economic one. Those who belong to the same chao have intimate social ties and extensive economic associations.

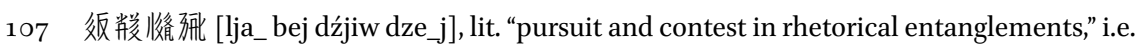
legal disputes. 
Will the penalty double the sale price of the land, upon willing agreement, but also let the party reneging on its promise bear any responsibility in accordance with the Laws and Orders, and pay 2 liang of gold according to the government regulations. Own hearts Willing. 4 boundaries ${ }^{108}$ are now specified,

To the east it borders the land of 垪碰桶 [kə ta nja_] (the black little puppy) and 䊩鲜挀 [ko dji-nja ?] (Su black?); To the South, that of

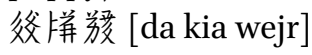

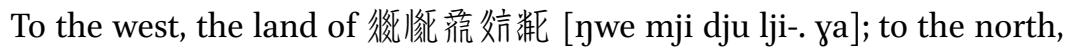
the land of 㸷垓 [ljow ywie]?

Tax: 1 out of 5 dou of wheat; water for irrigation

All terms are to be enforced according to the terms set in this document.

Contract Party: 鿴徽嗳 [khjiw bie_j ta] (stamp)

Co-Contract Party: son, 形吺㛂 [tśhjwor nja_], 'the black slave' (stamp)

Co-seller ${ }^{109}$ son, 难妲 [khjwi- njij], 'the red dog' (stamp)

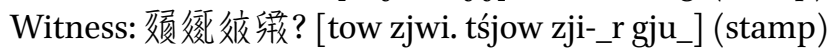

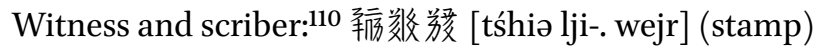

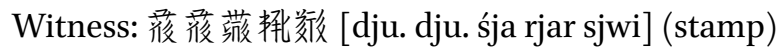

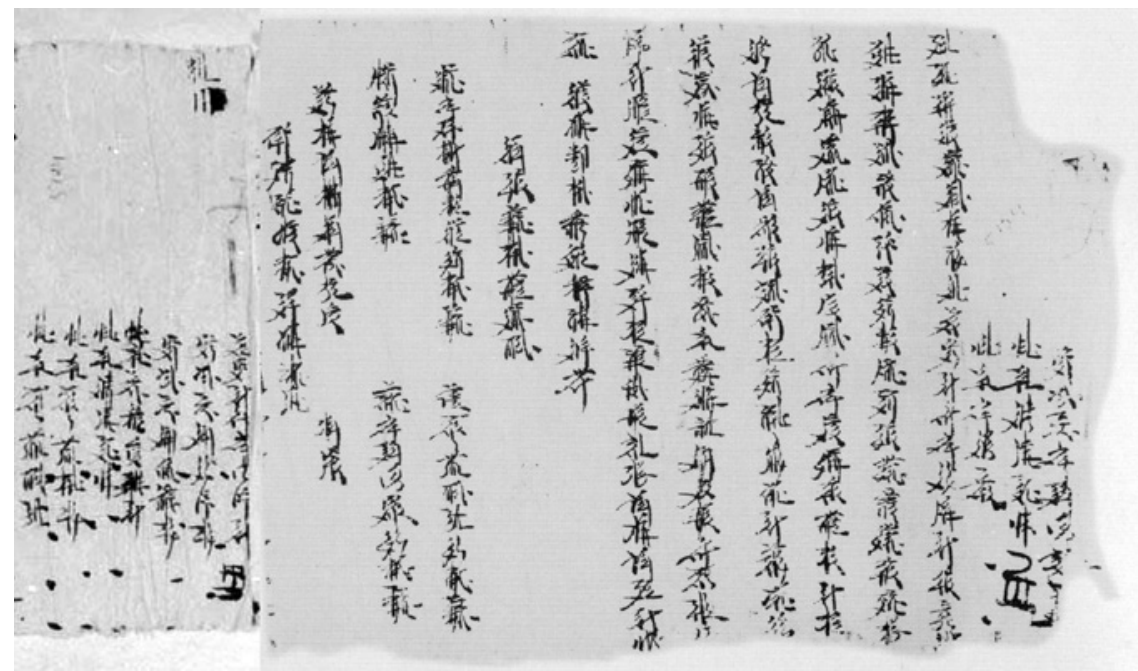

FIGURE 150 Инв. No. 5124-1, 5124-3(3): 29th day of 1st month in Yin year of Tianqing (1194)

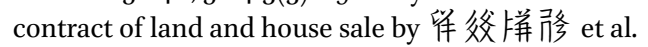

108 㻒夜 [lji-r we], the four enclosures, i.e. the four ends, borders.

109 㫪䒵 [źji. dźjwi-], lit. to sell with, i.e. co-seller.

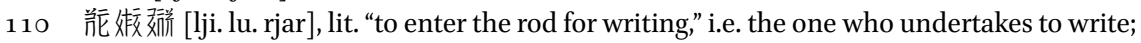
the professional transcriber who handwrites the entire contract, and also acts as a witness to the agreement. 
3. Инв. No. 5124-1, 5124-3 (3): contract of land and house sale by 倠父拼骰 [ljow da kia -jiw] on the 29th Day of 1st Month in the Yin Year of Heavenly Prosperity (1194), reassembled from the contract scroll Инв. No. 5124-1 and lines 7-13 in the third part of 5124-3. There are 20 lines of Tangut in the cursive, followed by stamps and signatures. ${ }^{111}$

Translation:

On the 29th Day of 1st Month in the Yin Year of Heavenly Celebration, ${ }^{112}$

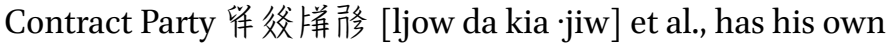

Land fit to sow 15 dan $^{113}$ of seeds, irrigated by water from the end of the left canal, along with the house and yard, trees and stone graves? etc. altogether

Sold to the grain-agent of the Pudu Temple, 铮㣪姘 [ljow lja mja] et al., at the agreed-upon ${ }^{114}$ price

of 6 dan of wheat and 1o dan of coarse grains. Debt incurred in neither the payment nor the land. If other

parties attempt to transfer or loan the title, either publicly or privately, or if members of the same chao initiate a dispute, let 爸拼胗 [da kia .jiw] take responsibility, not 㣭姘异 [lja mja]. In that case, not only is the penalty fee double the sum of the original payment,

But there is an additional fee of 3 liang of gold in accordance with the laws of the government. Own hearts willing.

The four borders of the land are clearly specified.

To the east it borders the land of Liang "the lucky and accomplished"; to the south it borders 蕧蕧带航涕爱 [dju. dju. śja phji wejr]

To the west it borders the Pudao canal; to the north it borders the land of

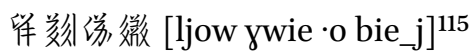

111 Russian Collection of Khara-Khoto Manuscripts, vol. 14, pp. 13 and 15.

112 A missing 婚 [nji-_] “day” is resupplied.

113 A missing 辡 [dźja_] "dan” is resupplied.

114 教䌸 [rji-r da.], lit. has already been said, i.e. negotiated and agreed upon.

115 TN: In some of the contracts, the third character of the name appears as 妶 [gia_], which means the same as 㣢 [·o]. Not being able to consult the man himself, for the sake of expediency and clarity (to differentiate between this man and 篗刻经洛, whose second character for "force" and "power," by the way, was mis-transcribed as 絔 in many texts, including, unfortunately, the Chinese edition of this book), and in order to maintain consistency, I have translated the name as 留刻㣢微 throughout the book. But note that

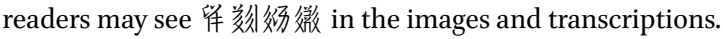


Tax is 2 dan, including 4 dou of wheat; there is water for irrigation

The terms are to be enforced according to the items listed in this document

Contract Party: 篗条栟胗 [ljow da kia jiw] (stamp)

Co-Contract Party: younger brother 爸拼邹 [da kia lji-.], treasure of the old house (finger-segment)

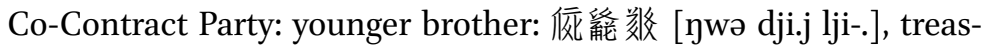
ure of the five realms (finger-segment)

Co-witness: son, 裳? [zji-r ? ·jiw] (finger-segment)

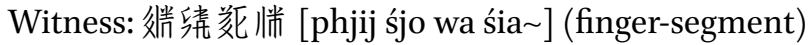

Witness: 蕧後带粍数 [dju. dju. śja rjar lji-.] (finger-segment)

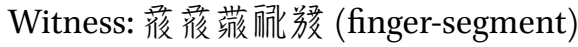

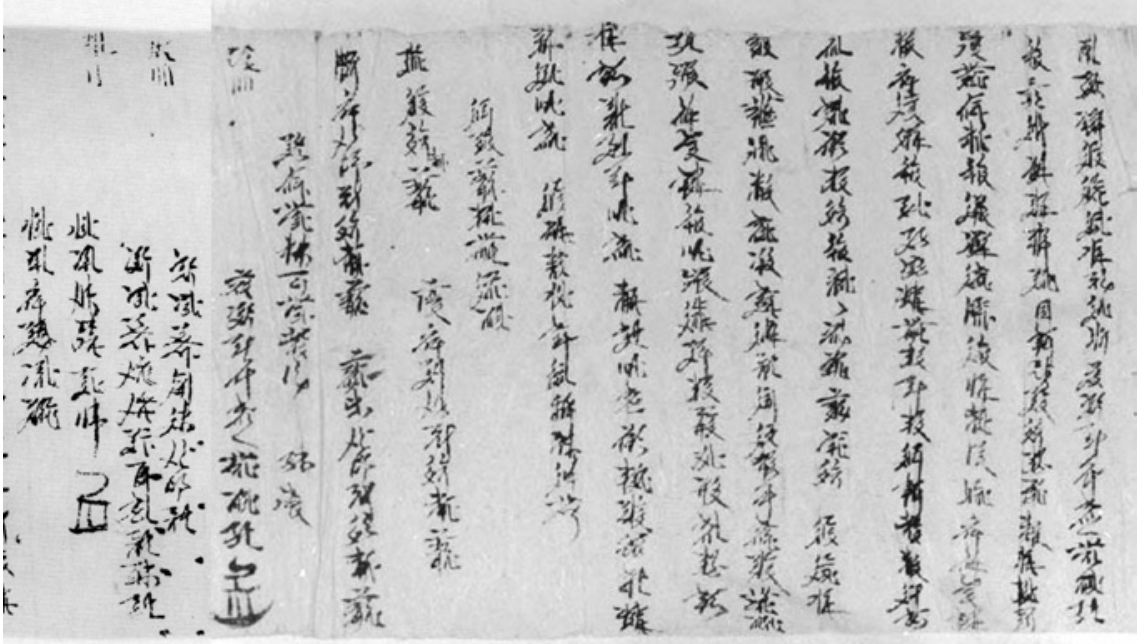

FIGURE 151 Инв. No. 5124-3 $(4,5)$ : 29th day of the 1st month in Yin year of Tianqing (1194) contract of land sale by 後後带解侸

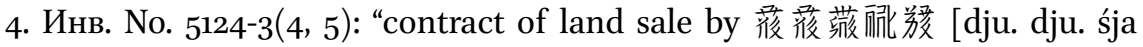
phji wejr] and prosperous" on the 29th Day of 1st Month in the Yin Year of Tianqing (1194). The contract begins with line 4 in part 4 of the long scroll Инв. No. 5124-3 and ends with the beginning of part 5. The 18 lines of Tangut in the cursive are followed by stamps and signatures. ${ }^{116}$

116 Russian Collection of Khara-Khoto Manuscripts, vol. 14, p. 16. 
Translation:

On the 29th Day of 1st Month in the Yin Year of Heavenly Celebration, Contract Party 後後带甪 [dju. dju. śja phji]

Et al., has her own land fit to sow 8 dan of seeds irrigated by water from the end of the left canal, along with a two-cabin

House, 5 live trees, etc., voluntarily sold to the grain-agents from the Pudu Temple, 倠神

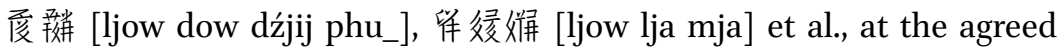
price of 4 dan of wheat \& 6 dan of coarse grains,

No debt incurred in payment or in land. If other parties attempt to transfer or mortgage the title, either publicly or privately,

Or if the members of the same chao should initiate any dispute, let Xianling be responsible,

Not 祩爱靱 [dow dźjij phu_] et al. In such cases, let not only the penalty double the sale price,

But the regretting or reneging party be prosecuted in accordance with the Laws and Orders,

And pay a fee of 1 liang of gold, as required by the government. Own Hearts are willing.

The four borders of the land are hereby specified:

To the east it borders government-owned land; to the south it borders the

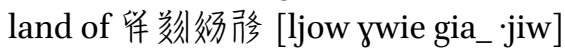

To the west, it borders the land of 倠㳇拼俢 [ljow da kia jiw]; to the north, it borders the land of "little old house of Year You"

Tax is 5 dan, including 1 dou of wheat narrow water [canal for irrigation]

Contract Party: 後後带解聠 [dju. dju. śja phji wejr] (stamp)

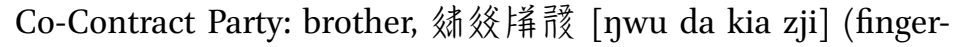
segment)

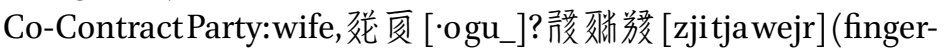
segment)

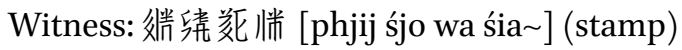

Witness: 倠?? [ljow? sa?] 


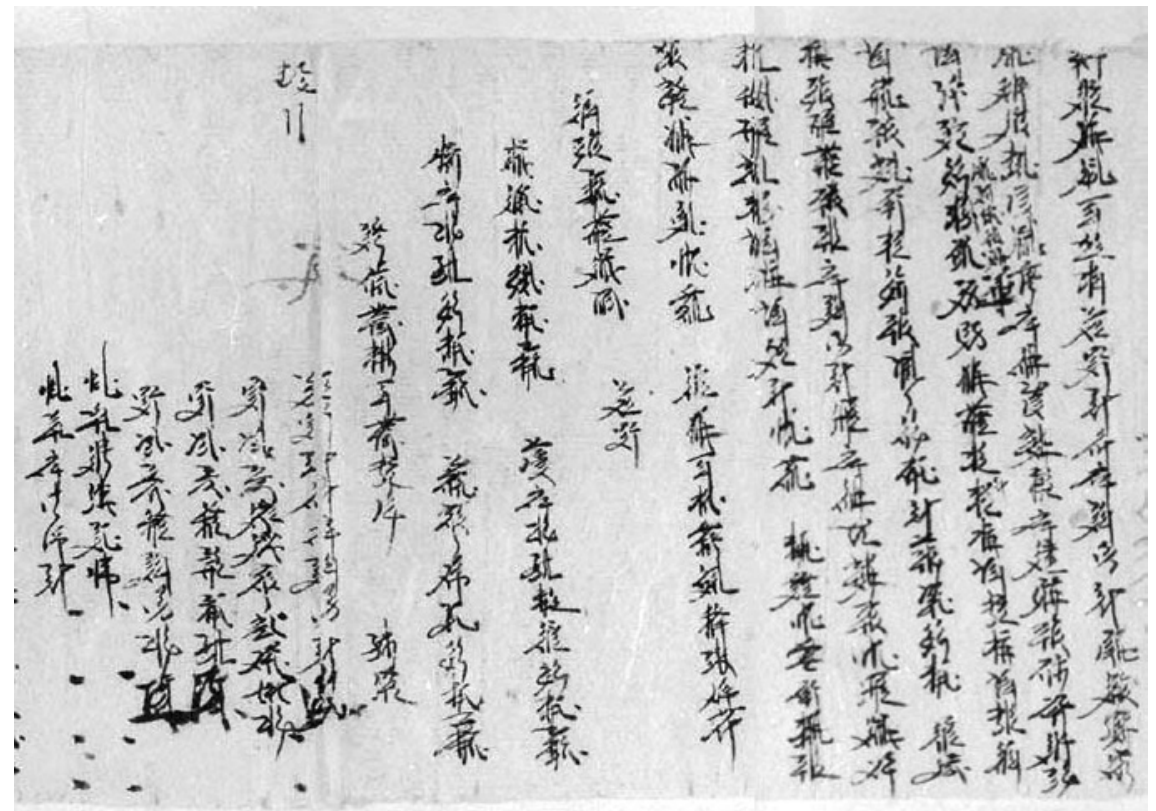

FIGURE 152 Инв. No. 5124-3 (6, 7): 1st day of 2nd month in Yin year of Tianqing (1194) contract of land sale by 留刻彻捐

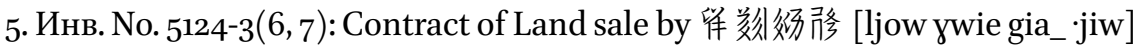
on the 1st day of the 2nd month in the Yin Year of Heavenly Celebration (1194). The main text of the document is found in the long scroll Инв. No. 5124-3 and patched together from the end of image 6 and the beginning of image 7 . There is a total of 18 lines of cursive Tangut, ending with signatures and stamps. ${ }^{117}$

Translation:

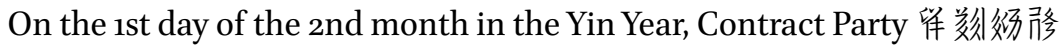
[ljow ywie gia_.jiw] presently to Pudu Temple's

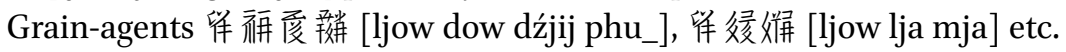
has a ripe/unripe

Land fit to sow 10 dan of seeds, houses and walls included, voluntarily sold, at the agreed price of 2 dan of wheat, 2 dan of millet,

And 4 dan of grains. There is no discrepancy in either land or payment. If there ever arise any attempt to either publicly or private

Transfer or loan the properties on this land, let 傕垓彻侈 [ljow jwie gia .jiw], not Liang Nahzengmao et al., bear the responsibility. Not only

117 Russian Collection of Khara-Khoto Manuscripts, vol. 14, p. 17. 
Let the recompensation be double the sum of the original sale price, but whichever party reneges on the promise,

Let it be prosecuted according to the laws and orders and suffer the penalty of liang of gold by the government. Own hearts are willing.

The four borders are hereby specified: [contract] ${ }^{118}$

To the east, it borders Weiyi River; to the south, the land of 牮敚聠

[ljow lji-. wejr] and government-owned land,

To the west it borders sthe land of 稚数嗳 [ljow lji-. wejr]; to the north

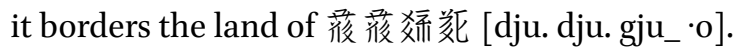

Tax is $5 \mathrm{dou}$, including 1 dou of wheat. Narrow water for irrigation

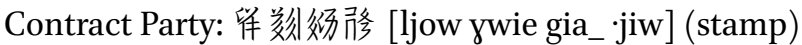

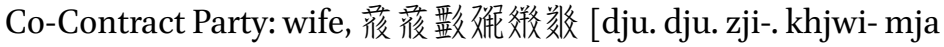
lji-.] (finger segment)

Co-Contract Party: son, 影㭱郱 [zjo. dźjo wejr] (stamp)

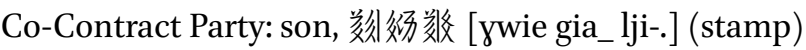

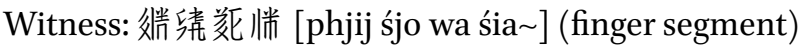

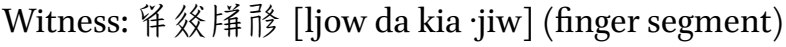

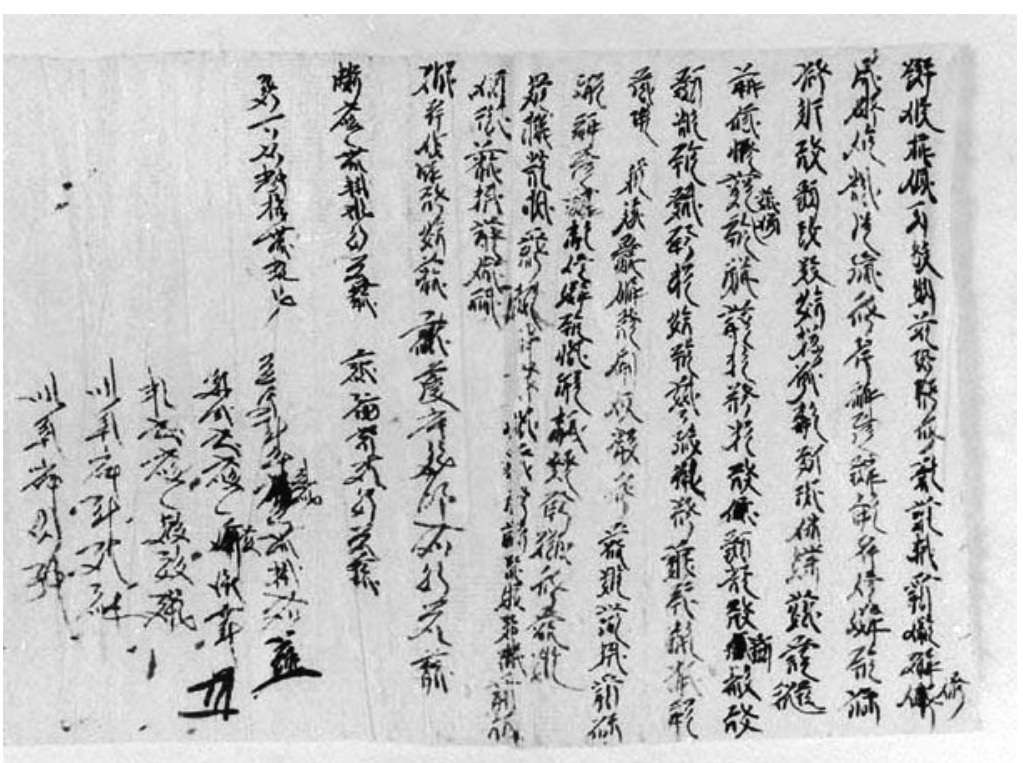

FIGURE 153 Инв. No. 5124-3(1-1): 1st day of 2nd month in Yin year of Tianqing

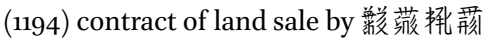

118 These two characters are superfluous, and probably misplaced. Possibly, the transcriber intended to start recording the identities and names of the contracting parties, but switched gears upon realising that he has not yet produced information on the four borders and the taxes. 


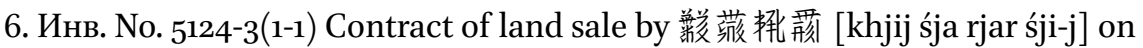
the 1st day of the 2nd month in the Yin Year of Heavenly Celebration (1194), identified in image 1 in Инв. No. 5124-3, the long scroll of contracts. The text of 17 lines in cursive Tangut ends with signatures and stamps. ${ }^{119}$

Translation:

On the 1st day of the 2nd month in the Yin Year, Contract Party 藉带批荊 [khjij śja rjar śji-j], to Pudu Temple's

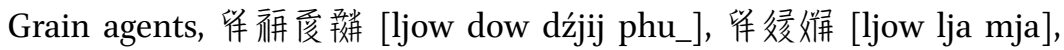
et al.,

Sell a patch of ripe/unripe land fit to sow 10 dan of seeds, along with cottages large and small, farming tools for the oxen,

Stone gate with fence, pentamerous yokes, tree yard, etc. at the agreed-upon price of 10 dan of wheat, 10 dan of coarse grains,

10 dan of millet. Neither payment nor land falls short. If other parties,

Such as members of the same chao, either publicly or private initiate a dispute, let Luocheng be responsible,

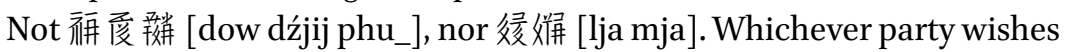
to change these terms, let there be

Not only a penalty fee of 3 liang of gold according to the laws, with their hearts willing, but also let the terms of the contract be enforced according to document and given the requirements of the circumstances.

The four borders of the land are clearly delineated:

To the east, it borders the land of 倠父拼胳 [ljow da kia jiw]; to the south, the land of 留效拼茫 [ljow da kia dju]

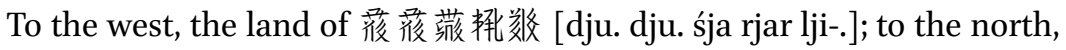

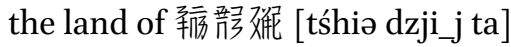

The tax is 10 dan of grains, ${ }^{120}{ }_{2}$ dou of wheat

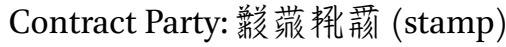

Co-Contract Party: 後後很??蒜 [dju. dju. rji-r mja kie.] (stamp)

Co-seller: 後後行效㖁 [dju. dju. wja. śjwo khjwi-] (finger-segment)

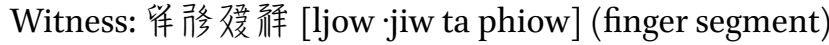

Witness: 筹街㔙 [ljow ne_w wejr] (finger segment)

119 Russian Collection of Khara-Khoto Manuscripts, vol. 14, p. 14.

120 The Tangut character for 'grain' here refers to foodstuff in general. 


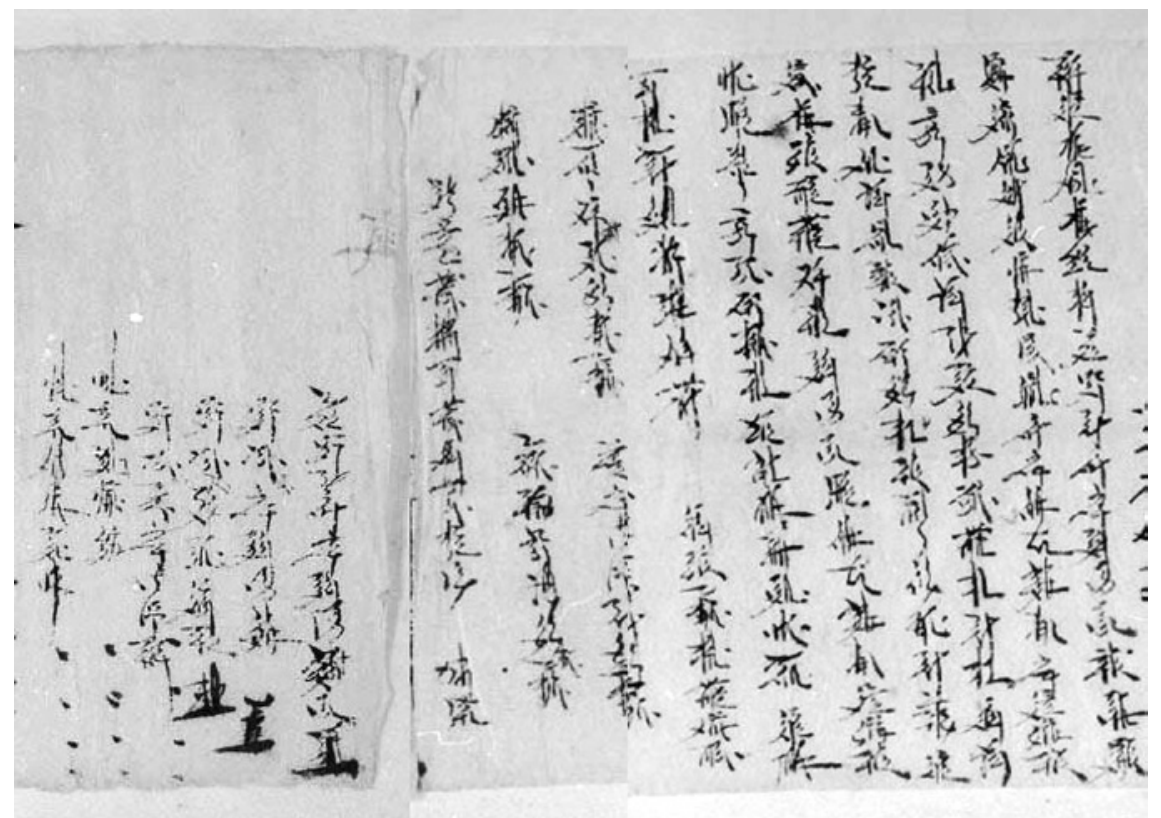

FIGURE 154 Инв. No. 5124-3(2, 3), 5124-4(1): 2nd day of 2nd month in Yin year of Tianqing

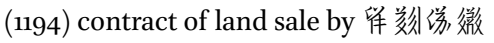

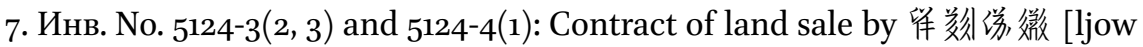
ywie $\cdot 0$ bie_j] on the 2nd day of the 2nd month in the Yin Year of Heavenly Celebration (1194) is found in the long scroll of contracts, reprinted in volume 14 of the Russian Collection of Khara-Khoto Manuscripts. The main text is reassembled from the end of part 2 in Инв. No. 5124-3, and the beginning of part 3 , as well as the first 6 lines in part I of 5124-4. There is a total of 16 lines in cursive Tangut, followed by stamps and signatures. ${ }^{121}$

Translation:

On the 2nd day of the 2nd month in the Yin Year, Contract Party 铛刻㣢 微 [ljow ywie $\cdot o$ bie_j] et al., presently out of their own will, to $\mathrm{Pu}-$

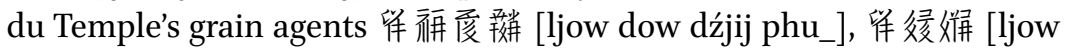
lja mja], et al.

sells his patch of land fit to sow 5 dan of seeds at the agreed price of 4 dan of wheat and 9 dan of coarse grains. There is no discrepancy in either land or payment. If either publicly

or privately, there should ever arise any attempt to transfer or mortgage this title, let 垓㣢徽

121 Russian Collection of Khara-Khoto Manuscripts, vol. 14, pp. 15 and 18. 


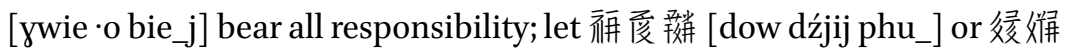
[lja mja]

share no liability. Whichever party should violate the agreement, let it not only be prosecuted by the laws, but also, according to the government's rules, pay 1 liang of gold as a penalty fee. Own hearts willing. The four borders of the land are clearly demarcated:

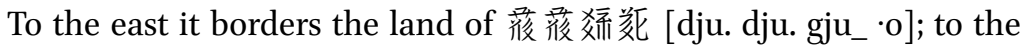
south it borders the land of 留㳇拼骰 [ljow da kia jiw]

To the west it borders the canals for irrigation; to the north it borders

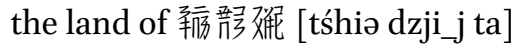

The tax is $7 \mathrm{dou}$, including 1 dou 4 sheng of wheat. Narrow water is used for irrigation.

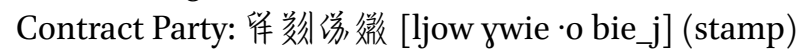

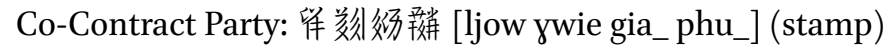

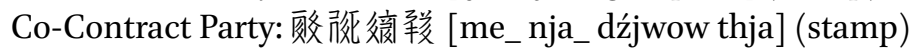

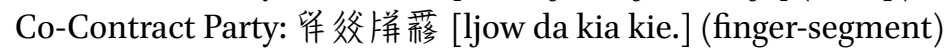

Witness: Chen Yanshuang (finger-segment)

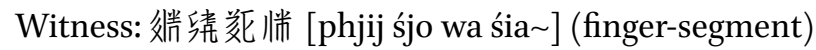

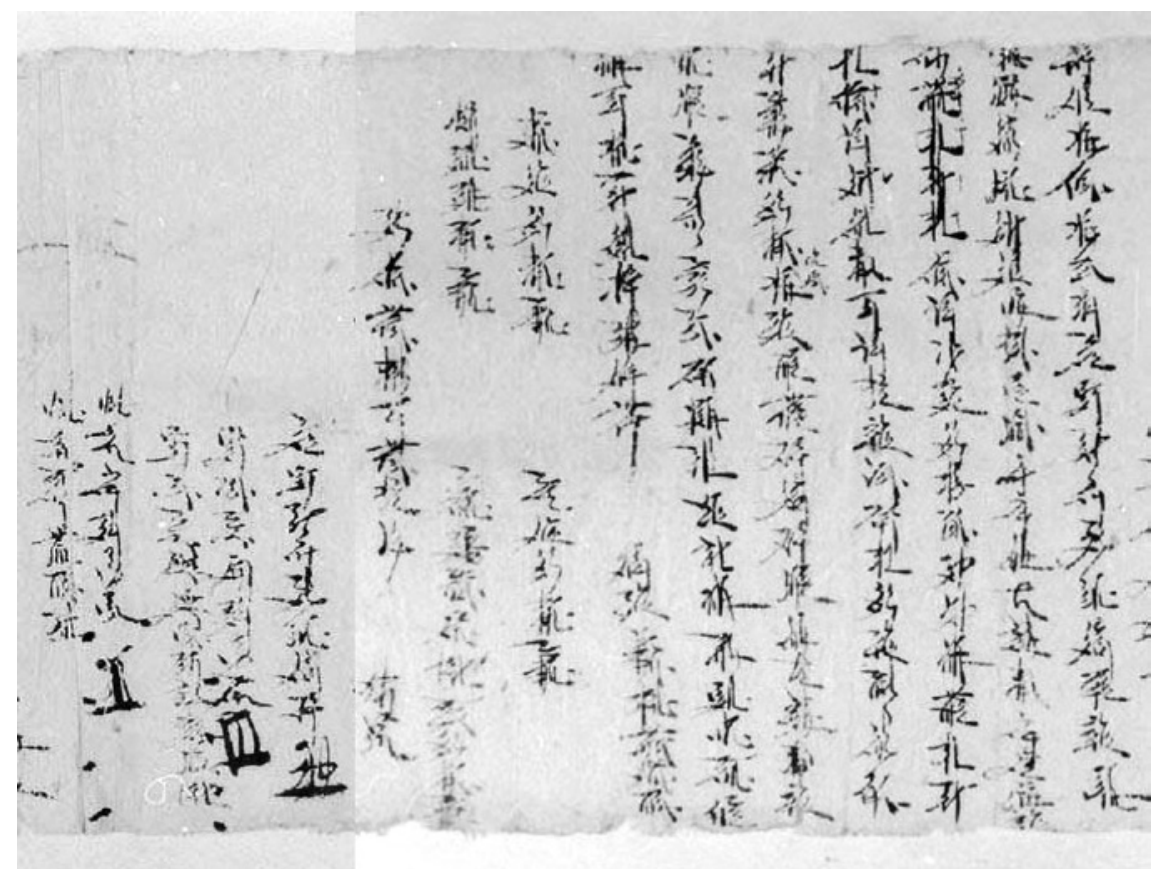

FIGURE 155 Инв. No. 5124-4 (2, 3): 2nd day of 2nd month in Yin year of Tianqing (1194) contract of land sale by 酷䝠熵䠹 


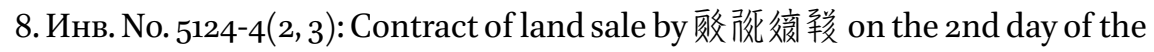
2nd month in the Yin Year of Heavenly Celebration (1194 AD). The manuscript is a part of the long scroll of contracts, reprinted in Volume 14 of the Russian Collection of Khara-Khoto Manuscripts. It is reassembled from the later section of image 2 and the first part of image 3 in Инв. No. 5124-4. There is a total of 16 lines of cursive Tangut. The contract ends with signatures and stamps. ${ }^{122}$

Translation:

On the 2nd day of the 2nd month in the Yin Year, Contract Party 酸挀德 䚗 [me_nja_dźjwow thja] et al., presently

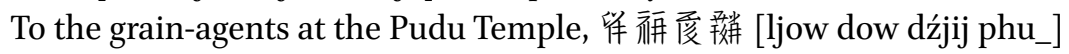
and Liang La-

ma, etc. voluntarily sells a patch of land large enough to sow 5 dan of seeds, at the agreed price of

6 dan of coarse grains and 1 dan of wheat. There is no discrepancy in payment or in land.

In case of any attempt to transfer or mortgage the titlte of this land, let

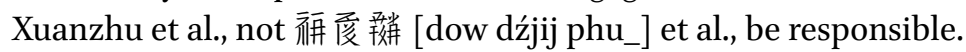

Whichever party violates these terms, let it not only bear legal responsibility according to the Laws and Orders,

But also pay 1 liang of gold as a penalty fee. Own Hearts willing. The four borders of the land concerned are clearly demarcated:

To the east it borders government-owned land. To the south it borders government-owned land.

To the west it borders the canals for irrigation. To the north it borders the land of Lu?? Matie.

The tax is $5 \mathrm{dou}$, including 1 dou of wheat. Narrow water for irrigation.

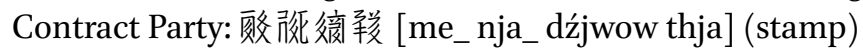

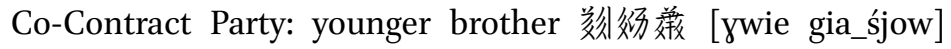
(stamp)

Co-Contract Party: wife, ?? (finger-segment)

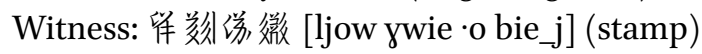

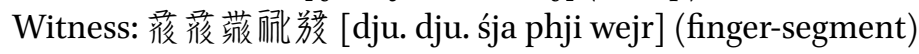

122 Russian Collection of Khara-Khoto Manuscripts, vol. 14, p. 19. 


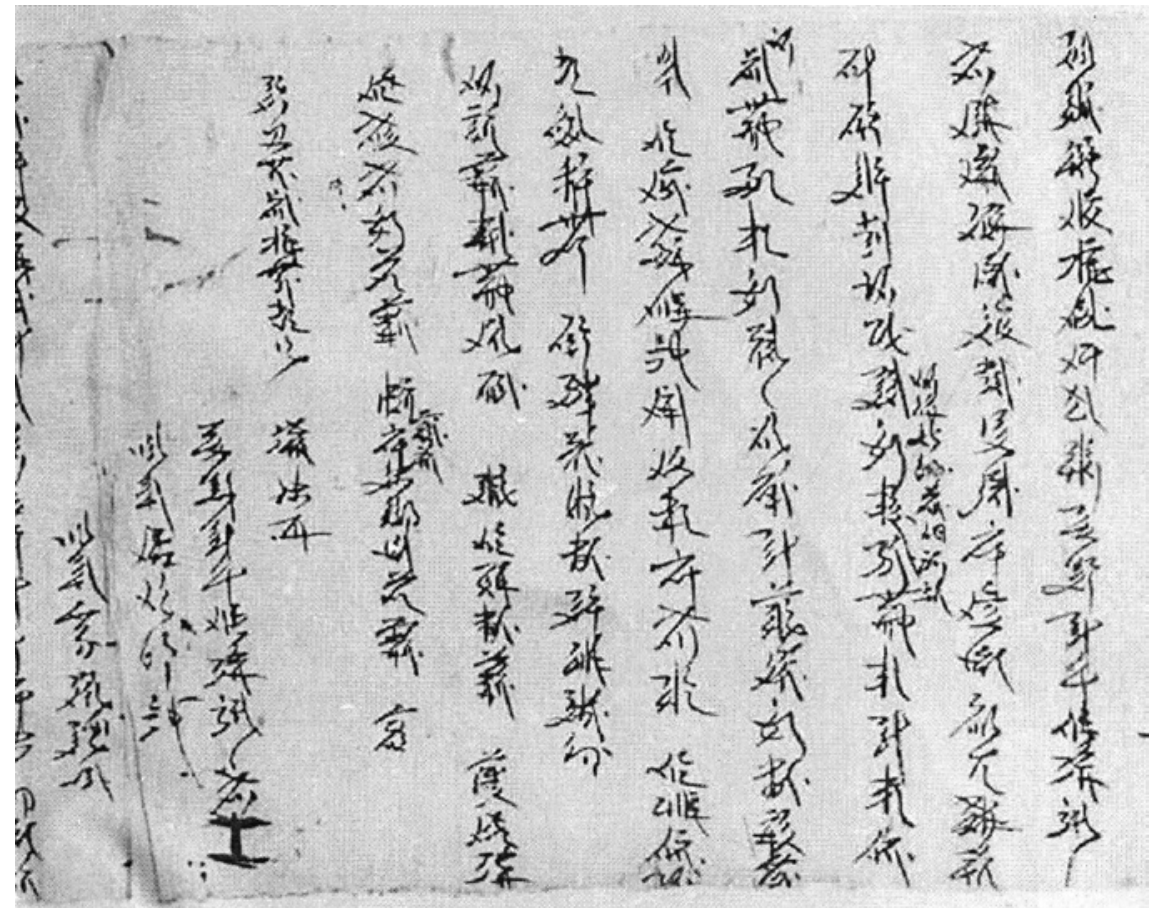

FIGURE 156 Инв. No. 5124-4(6): 6th day of 2nd month in Yin year of Tianqing (1194)

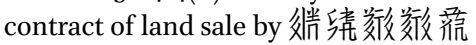

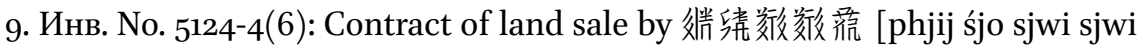
$\mathrm{dju}$ ] on the 6th day of the 2nd month in the Yin Year of Heavenly Celebration (1194). It consists of 14 lines of cursive Tangut in the long scroll of contracts, ending with signatures and stamps. ${ }^{123}$

Translation:

On the 6th day of the 2nd month in the Yin Year of Heavenly Celebration,

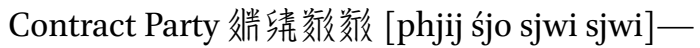

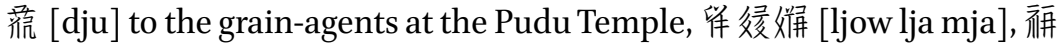
爱敔羊 [dow dźjij phu_] et al., sells a patch of ripe/unripe land fit to sow 3 dan of seeds, along with an old four-cabin house, etc. at the price of 5 dan of coarse grains, which is already paid. There is no discrepancy in either the payment or the land. If on this land any other party,

123 The image of the original manuscript should have been included in the Russian Collection of Khara-Khoto Manuscripts, vol. 14, p. 21. However, for some reason that page is blank. But the image is resupplied below. 
such as members of the same chao, should either publicly or privately dispute the property ownership, let the penalty be, in accordance with the laws established by the government, 5 dan of

wheat. Hearts willing. Let the contract be enforced according to the circumstances and to the terms set herein.

The four borders are clearly demarcated: to the east it borders government-owned canals; to the south it borders the land of Xishang Nüyou; to the northwest it borders the land of Liang "the donkey's mother" to the north ${ }^{124}$

The tax is 8 dou of coarse grains and 2 dou of wheat; half a narrow stream of water suffices to irrigate the land.

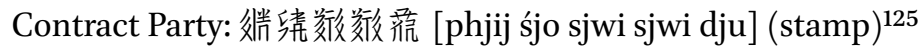

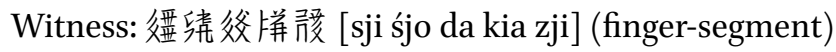

Witness: 蕫佰效徽 [khjiw khjwi- phə bie_j] (finger-segment)

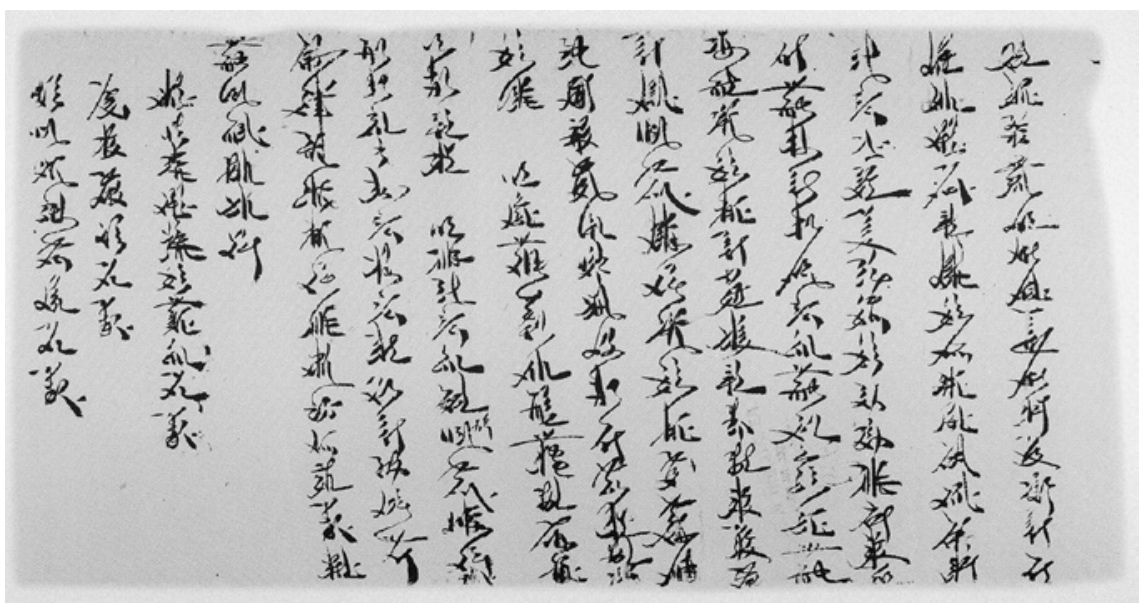

FIGURE 157 Инв. No. 4199: 16th day of 6th month in Bingchen year of Tianqing (1196) contract of land sale by 留倠剂??

124 The character is incomplete. It could have been the character for expanse/border.

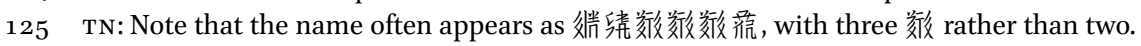
The reduplicated 授 is often translated into the Chinese character 歲, hence the best wishes for having a bit of wealth each and every year. The character itself also means fortune and luck. So, it amounts to the same meaning, more or less. 
10. Инв. No. 4199: Contract of land sale by 倠很姳?? [ljow śiə nio_w ??] ${ }^{126}$ on the 16th day of the 6th month in the Bingchen year of Heavenly Celebration (1196 AD). It is a single-page manuscript with 15 lines of cursive Tangut handwritten on a $23.5 \times 45 \mathrm{~cm}$ hemp paper. ${ }^{127}$

Translation:

On the 16th day of the 6th month in the Bingchen year of Heavenly Celebration, Contract Party [ljow $]^{128}$

㷋㸚?? [śia nio_w ??] et al., presently has his own ripe/unripe land, watered by the canal at the hillside of four wells,

Which is $70 \mathrm{mu}$ large and fit to sow 10 dan of seeds, voluntarily sold to 㸷被羰遂 [ljow tśju. 'wejr śjow]

At the price of 5 dan of coarse grains. Each ?? bought,

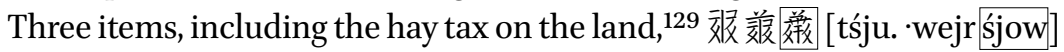

Bears the costs; other than that, first?, on this land, if

Other members of the same chao strive to dispute the property ownership, ?

Attempt to either publicly or privately transfer? Or loan the land, and who??

Let the relevant party not only pay 10 dan of grains as a penalty fee, according to the laws set by the government, but also

Recompensate double the sum of the original purchase price. Own hearts willing.

Let the agreement be enforced according to what is written in the contract and required by circumstances. The four borders [of the land]

Are clearly demarcated. ?:

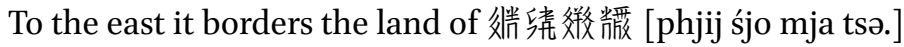

To the south it borders the land of Cao "Iron"?

To the west it borders the land of Weiming "the prosperous and entertained" ..... ${ }^{130}$

126 TN: The name is barely legible. The author's guess is that it is a four-character name: “Liang, benevolence, cause, bear, sound." Here, I've given only the first three characters.

127 Russian Collection of Khara-Khoto Manuscripts, vol. 13, p. 199.

128 The lower section of the contract suffers damages. There are missing characters in some lines. However, it is possible to resupply certain information in context, and based on common legal formulas in Tangut contracts.

129 Shi Jinbo, 2005 (a).

130 The contract is damaged near the end. Information on the northern border, along with the signatures and stamps of the main parties to the contract are missing. 


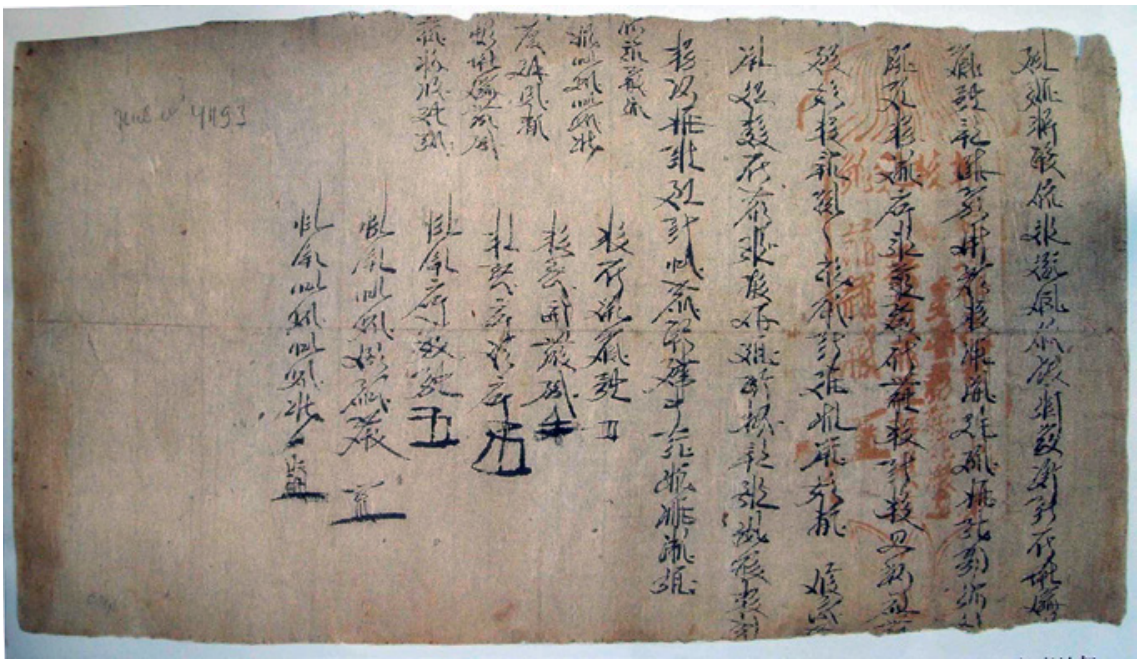

FIGURE 158 Инв. No. 4193: 5th day of 1st month, Wuwu fifth year of Tianqing (1198)

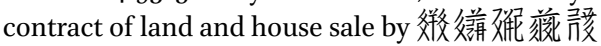

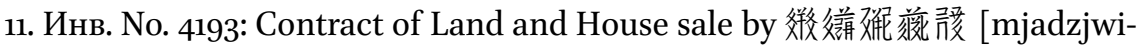
khjwi-wjazji] on the $5^{\text {th }}$ day of the 1st month in Wuwu, the fifth year of Heavenly Celebration (1198 AD). It is a single-page contract with 12 lines of cursive Tangut written on a $23.2 \times 43.1 \mathrm{~cm}$ hemp paper. The first line begins with the date, proceeds to the main content of the contract, and ends with the signatures and stamps, where the four borders of the land are demarcated. There are a lotus sign and a $22 \times 7 \mathrm{~cm}$ red seal. ${ }^{131}$

Translation:

On the $5^{\text {th }}$ day of the 1st month in Wuwu, the fifth year of Heavenly Celebration, Contract Party: Maze "old

Father and son" et al., presently have their own 23 mu of land irrigated by the water from the Mingbu Hillside Canal ${ }^{132}$

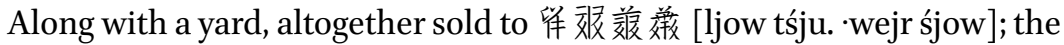
price, in 8 dan of coarse grains, has been paid.

There is no discrepancy in either the payment or the land. Hereafter, should any party either publicly or private

131 Russian Collection of Khara-Khoto Manuscripts, vol. 13, p. 194.

132 The Tangut character for qing (刘高) looks quite similar to $m u$ (秱). The two are especially easily confused in cursive writings. Given the ratio of land prices, it is more likely that the intended character is $m u$. 
Launch a dispute or renege on the agreement, let the recompensation be double the sum of the sale price,

Each 1 dan is repaid 2 dan, ${ }^{133}$ and let the terms be enforced according to what is written in the document and required by the circumstances.

\section{(Upper section)}

The four borders of the land are clearly demarcated

To the east [it borders the land of]???? "the treasure"

To the south, the hillside where the canal is found.

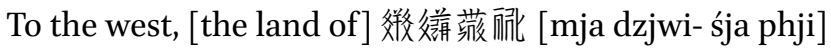

To the north, [the land of] Hun? "the black dog” (非垪嫹跪)

(Lower section)

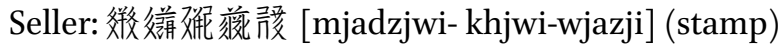

Co-seller: younger brother, 䓷配 [śja phji] (stamp)

Co-seller Liang?? (stamp)

Witness: Liang 蕧嗳 [la wejr] (stamp)

Witness: ??咯褯席 [??.ji. tsji_r śjow] (stamp)

Witness: ???? 貉 [???? lji-.] (stamp)

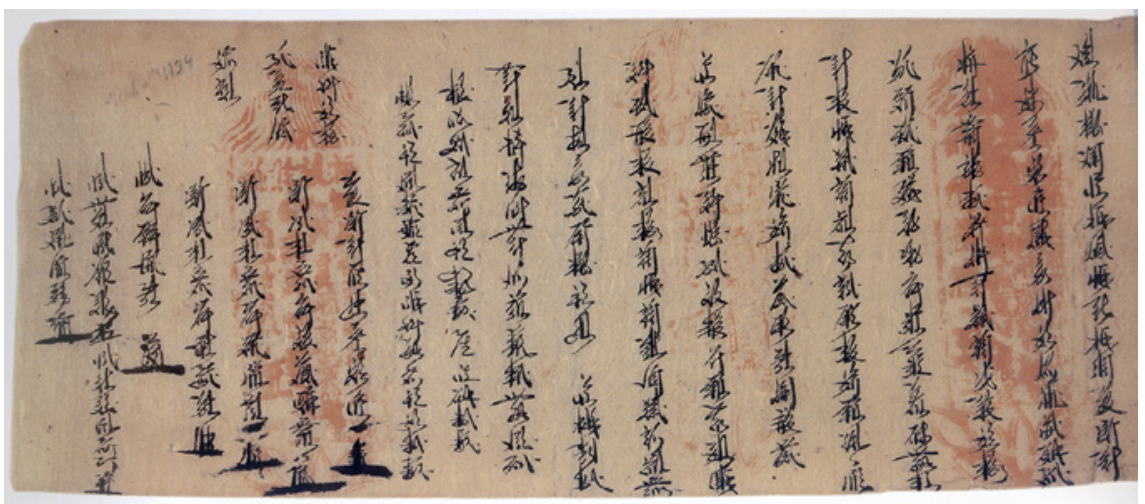

FIGURE 159 Инв. No. 4194: Gengshen year of Tianqing (1200) contract of land and house

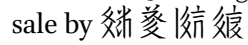

12. Инв. No. 4194: Contract of land and house sale by 㸚荾信良 [lew śji thow pha ] in the Gengshen Year of Heavenly Celebration (1200). It is a single-page manuscript with 19 lines of cursive Tangut handwritten on a $22.9 \times 57.1 \mathrm{~cm}$ hemp paper. It begins with the date and ends with the signatures and stamps. Above the stamps are the demarcations of the four borders of the land. There

133 The character for dan is missing. 
is also a lotus figure, and three prints of the official red seal of the $22 \times 7 \mathrm{~cm}$ House of Trade and Taxes. ${ }^{134}$

Translation:

On the 22nd day of the 2nd month in the Gengshen Year of Heavenly Celebration, Contract-

or 籹荾信良 [lew śji thow pha ] presently has his own land, irrigated by the canal of the Four-well hillside,

by the side of 垪效?挍荊 [xwe dźju_(?) bo_śji-j]'s land, a patch of ripe/ unripe land fit to sow 100 dan of seeds,

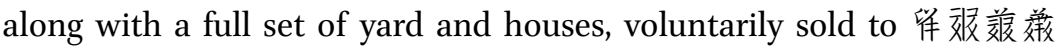
[ljow tśju. 'wejr śjow] at the agreed

price of 200 dan of coarse grains. There is no discrepancy in either the payment or the land

hereafter, if on this land any affiliates of these parties

attempt to transfer or mortgage the title, either publicly or privately, and fall into a state of chaos as they dispute over the property, let it be recompensated in twice the sum of the original sell \& purchase price.

Let the repayment be 400

dan, and any party which reneges on these terms should be penalised according to the laws by 3 liang

Of gold. Own hearts willing. The four borders of the land are demarcated: To the east, it borders???; to the south it borders the government-owned canal

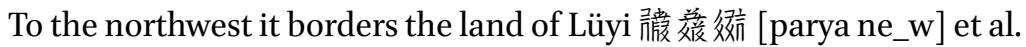
(Upper Part)

There was one

Patch of land that is 75

$m u$

(Lower Part)

Contract Party: 姠荾流永 [lew śji thow pha ] (stamp)

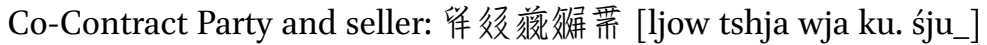
(stamp)

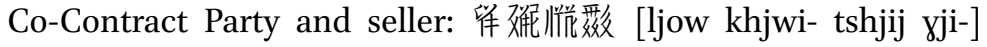
(stamp)

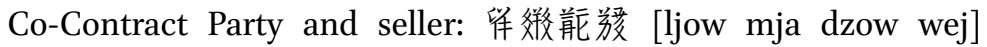
(stamp)

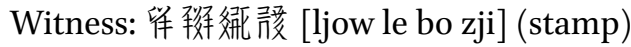

134 Russian Collection of Khara-Khoto Manuscripts, vol. 13, p. 194. 


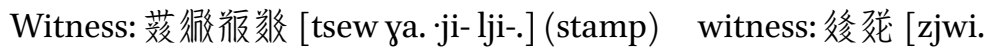
$\cdot$ o] 行? 刻 [wja. ? ywie] (stamp)

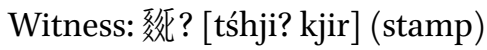

The 12 contracts presented and translated above show some general patterns. Overall, Tangut contracts of land sale inherit the same format from contracts in the Central Plains tradition. These Tangut manuscripts contain nearly all the essential elements of sell and purchase contracts. A thorough analysis of these legal documents open the door to a deeper understanding of land and transaction in Western Xia, as well as the Tangut society in general.

3.1 .2

The Reasons behind Land Sales and the Identities of the Buyers and Sellers

3.1.2.1 Time and Causes of Land Sales

The Tangut city of Khara-Khoto is located to the north of the Badain Jaran Desert, on the northern bank of the downstream inland waterways of the Ejin River, or the Black River. Indeed, Khara-Khoto's agriculture prospered in the Tangut era, thanks to the nourishment of the Black River. There is no better way to probe the conditions of farmland in this region than to survey this batch of Tangut land sale contracts.

The earliest amongst the 12 contracts is dated to the 22nd year of Heavenly Prosperity. Then come the 8 contracts in the Инв. No. 5124 scroll, all of which are signed in the first year of Heavenly Celebration (1194 AD). The remaining 3 documents are from the $3^{\mathrm{rd}}$, $5^{\text {th, }}$ and $7^{\text {th }}$ years of Heavenly Celebration (Tianqing), respectively.

Tangut power endured for a span of 190 years (1038-1227 AD) since the foundation of the Xixia dynasty. Given this time frame, it is obvious that these land sale contracts fall into the late period of Tangut history, across 31 years. Except for the earliest, which dates to the reign of Renzong Emperor, the other 11 all hail from the first 7 years of Huanzong Emperor's rule. The latest one was signed just 28 years before the fall of the Tangut Empire. Therefore, it should be said that this specific sample of Tangut land records, which happens to have survived to the present day, is only representative of the Khara-Khoto economy in the late Tangut period.

None of these land sale contracts openly states the reason for the sale. But the motives are not difficult to infer, given the dates and months recorded in these documents. All 8 contracts found in the long scroll provide precise dates, and all fall into either the first or the second months of the lunar calendar. Amongst the 4 individual contracts, one only documents the year but leaves the month and date unmentioned, which is quite rare and abnormal. All the 
other three begin with precise dates, two of which are also drafted in the first and second months of the new year, whereas one is written in the sixth month. To summarise, of the 11 clearly dated contracts, 10 are signed in the first and second months, right in the middle of the interim between two autumn harvests. Since land is the one fundamental factor of production on which entire households and extended families depend in rural Khara-Khoto, peasants never easily bring themselves to sell land. Although no direct evidence is available, it is safe to assume that the protagonists in these contracts are selling their land out of dire necessity, that is, shortage of grains at home. Under the duress and difficulty of poverty and starvation, the peasants are left no other option than to give up their land in exchange for foodstuff to feed on for the next six months or so.

The particular contract dating to the sixth month is signed on the 16th day of the 6th month in the Bingchen Year of Tianqing (1196). Liang, who sells $70 \mathrm{mu}$ of land at this strange time, must have been motivated by some personal reasons, rather than the hardship of life.

The limited number of Tangut contracts of land sale known to modern scholars are only a small fraction of this type of legal documents. Even the long scroll, where contracts are systematically compiled and densely concentrated, is only the temple's record for less than a single month-from the 24th day of the 1st month to the 2oth day of the 2nd month in the first year of Tianqing. It is remarkable how much land is sold within such a short span of time and within such a limited geographical scope-a single Buddhist temple. One could only imagine the plight of poverty faced by the local poor. Despite the abundance of farmland and the convenience of irrigation from the Black River, the contracts show that peasant families suffered grain deficits in the first and second months of the year. One possible cause was a natural disaster that might have befallen the area the year before, which would have sharply reduced the yield in the last harvest, thus cut the peasants off halfway through the tilling season, and forced them to sell land in exchange for food. In fact, many of the Tangut grain loan accounts also date to the years between Tianqing and Guangding, particularly the first year of Tianqing, suggesting that Tangut agriculture suffered a blow at the time. ${ }^{135}$ Social, legal, and economic documents such as these point to the possibility of a famine. However, since Western Xia is not represented in official imperial chronicles, there is scant historical source on natural disasters in Western Xia. No one is known to have recorded anything on natural calamities in Khara-Khoto.

135 Shi Jinbo, 2005 (b), pp. 186-204. 


\subsubsection{The Seller and the Size of Land Sold}

The earliest known Tanguts were experts in pasturing and livestock-raising, who knew little about tilling and sowing. As a result, there was a perennial shortage of grains amongst the Dangxiang tribes. But when Dangxiang power morphed into a stronger and stabler regime, and before the Tanguts founded the Xiazhou regime and proclaimed the status of an empire, a batch of husbandry-minded Tanguts turned to agriculture as they resettled on arable lands that recently fell under Tangut dominion. For an ethnos, this transition marked a historical transformation. It made entire populations of Tangut peasants, which never existed before. Most of the land-sellers we identify in Khara-Khoto contracts are descendants of this first generation of Tangut farmers. Nearly all the Contract Parties and witnesses are local, ethnic-Fan (Dangxiang Tangut) peasants: 羏朘 [.jaxwa], 捘峗 [mərar], 後後 [dju.dju.],

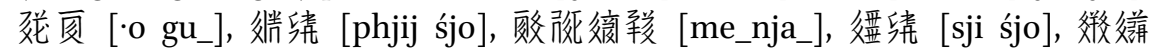
[mjadzjwi-], etc. There are also a handful of Han Chinese, such as the Qiu, Cao, and Chen. Liang is much more complicated: although it is originally a Han surname, we also know of ethnic Tangut Liangs, most notably the Liang empresses who championed the cause of Fan customs against sinicisation and Confucianisation in their nearly 30 years of rule and regency. So, there is no way to attest the ethnic make-up of the Liangs we see in Khara-Khoto land sale contracts. Historically, when the first Dangxiang Tanguts switched from pasturing to farming, they acquired and owned land allotted or approved by the government. These free farmers cultivated their own land and harvested their own grains, so long as they paid taxes to the state. But the late-Tangut contracts we have show that many of their descendants could no longer make ends meet, without selling their ancestral land.

The name of the seller, size of land, and quantity of assets as recorded in the 8 contracts in the Инв. No. 5124 scroll are, in respective order, (1) 無微硛 [khjiw bie_j ta] sells a patch of land fit to sow 20 dan of seeds along with the

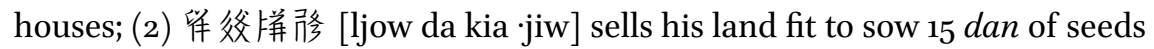
along with the houses, (3) 後後带甪嗳 [dju. dju. śja phji wejr] sells land fit

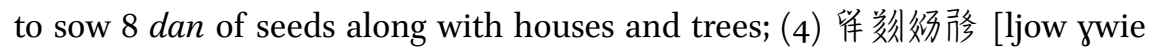
gia_- jiw] sells land fit to sow 10 dan of seeds along with the houses; (5) 萧带 叛荊 [khjij śja rjar śji-j] sells land fit to sow 10 dan of seeds, houses, tilling

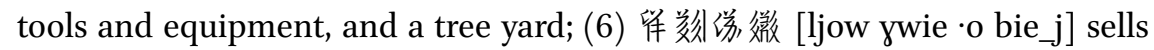

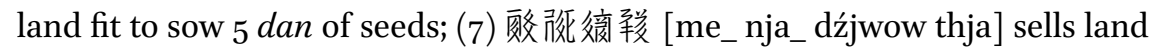

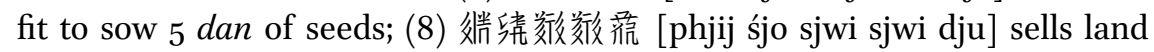
fit to sow 3 dan of seeds, along with the houses. The same information in the

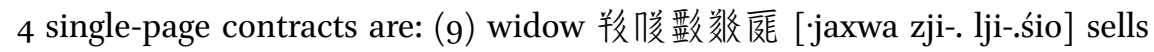
land fit to sow 2 dan of seeds along with the yard and three thatched cottages, 


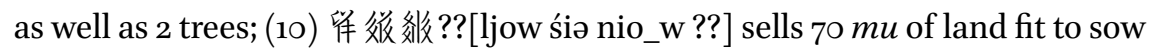
10 dan of seeds, watered by the canals from the Hillside of Four Wells; (11) 㸘徬

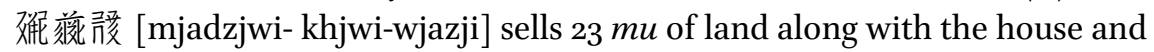

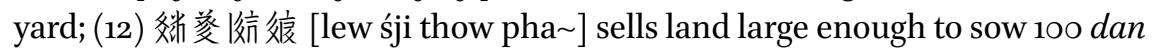
of seeds. All the sellers are the original owners of the title concerned. In most cases, they are the patriarchs of peasant households and male heads of the family. There is, however, one example of a matriarch and female head of the household, the widow 羏脜 [ j jaxwa].

The data in the contracts show a certain degree of disparity in land size across households. Most contracts do not indicate the precise size of the land in standard measurements, such as qing or $m u$, but in the amount of seeds (dan) to be sowed in a patch of land. But wherever both measurements are given, it is possible to find a rough conversion rate. For example, the widow 羓朘 [·jaxwa] sold $22 \mathrm{mu}$ of land, where 2 dan of seeds can be sowed. That is, each dan of seeds is sowed on a little more than $10 \mathrm{mu}$ of land. The land sold by 篗後涤?? [ljow śiə nio_w ??] is $70 \mathrm{mu}$ in size, large enough to sow 10 dan of seeds. There, the unit of land for 1 dan of seeds is less than $10 \mathrm{mu}$. Therefore, it should be noted that to measure land size by dan of seeds sowed is only an approximate measure. However, it may be assumed for the purpose of simplification and generalisation that a unit of land for 1 dan of seeds is more or less the equivalent of $10 \mathrm{mu}$.

The land sizes as recorded in the 8 contracts of the long scroll are, in the amounts of seeds to be sowed, 20 dan, 15 dan, 8 dan, 10 dan, 10 dan, 5 dan, 5 dan, 3 dan; or, once converted to the measurement of area: 200, 150, 80, 100, 100, 50, 50, 30 Tangut $m u$. The land ranges between 7.5 to 50 Song $m u$. One could tell that an average Tangut household owns a large amount of farmland. This is unsurprising, given the far northwestern location of Khara-Khoto, the wide space and sparse populations in the area. Land size varies more sharply

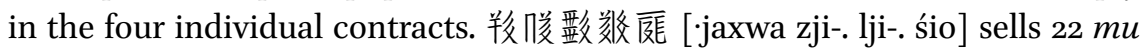
of land, whilst 姅萲颜良 [lew śji thow pha ] sells land large enough to sow 100 dan of seeds, roughly a thousand $m u$ (or 25 o Song $m u$ ) of land. This is an outlying datapoint, statistically, and a very special case of land sale, historically.

\subsubsection{Buyers and the Quantity of Property Purchased}

The buyers in all the 8 contracts across the manuscript scroll are the same two

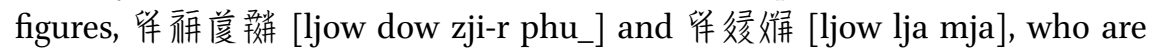
referred to as 'the ones who handle the grains,' i.e. agents employed by the Pudu Temple to manage the temple's assets and properties. They could as well be monks based at the temple. 啳姘 [lja mja] is obviously the a for a follower 
of the Dharma in Tantric Buddhism. Originally, it is reserved for the thera, ${ }^{136}$ a learned elder, a bhadanta. ${ }^{137}$ But over time, the term proliferated to more common usage, and came to mean any Buddhist monk. Given the prevalence and popularity of Tantric Buddhism in Western Xia, the Pudu Temple is likely to have been a Tantric monastery. Moreover, this particular temple in Khara-Khoto is unmentioned in Chinese sources. The contracts tell us that by this time, monks in charge of pragmatic affairs, such as managing grains and land, were called Lama. It could be the case that "Lama" already turned into a generic title for any monk in the Tangut period.

The long scroll of contracts shows that within less than a month in the spring of the first year of Heavenly Celebration, the Pudu Temple bought in a startling $760 \mathrm{mu}$ of land, or approximately 190 in Song $m u$.

Of the four single-page contract manuscripts, the first was signed by widow

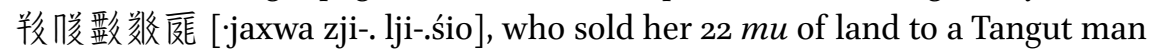
by the name of 羓朘椂挍 [.jaxwa mji-_tshja]. The buyer in the other three con-

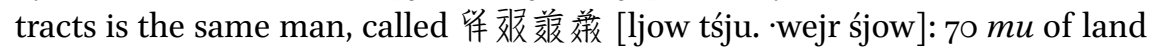
for sowing 10 dan of seeds, $23 \mathrm{mu}$, and land fit to sow 100 dan of seeds; in total, around $1000 \mathrm{mu}$ of land. This is an enormous amount of land to purchase. The seller 姅茲渷良 [lew śji thow pha ] does not sound like an everyday peasant, but rather a landlord of some wealth and capacity. For the buyer 释裉 聚爰 [ljow tśju. 'wejr śjow] to acquire so many properties within the span of 5 years, he would have been an even more powerful landlord and grain-owner. Curiously, the Инв. No. 5949-2 Khara-Khoto military liu report is signed by a

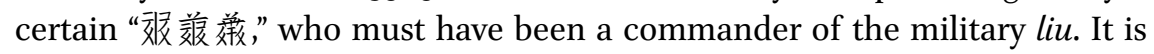

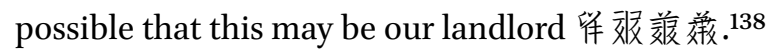

\subsubsection{Farmland and Irrigation \\ 3.1.3.1 Farmland and Yard}

There is a noteworthy phenomenon in Tangut land transfers: the fixed asset is included in the sale. When a previous landowner sells the title of his or her property, more often than not, the farmland comes with yards, buildings, and

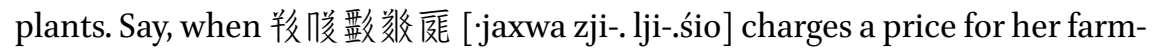
land, she sells the fixed assets attached to the land, in the same deal: a yard, 3 thatched cottages, and 2 trees. Likewise, 蓠微嫒 [khjiw bie_j ta] sells a yard and a house along with his land. 㳇拼胗 [da kia jiw] sells not only the house

\footnotetext{
136 TN: Sanskrit: स्थवरि.

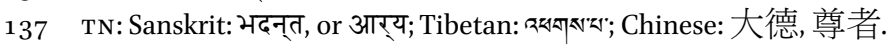

${ }_{13} 8$ Russian Collection of Khara-Khoto Manuscripts, vol. 14, p. 72.
} 


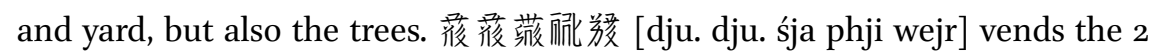

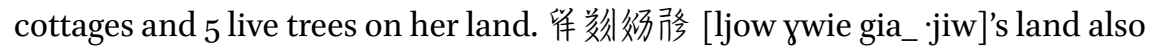

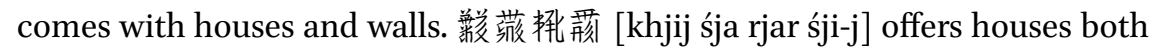

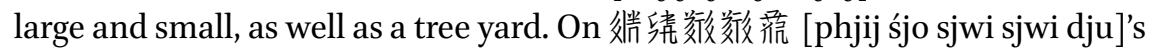

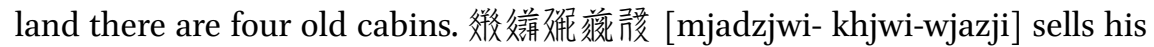
yard on the land. Finally, 峬荾校良 [lew śji thow pha ] sells both the yard and the house along with the farmland. In 9 out of the 12 contracts, land comes with houses and yards. In 2 of the remaining 3 documents, the land to be sold

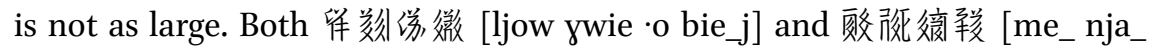
dźjwow thja] sell a patch of land only just enough to sow 5 dan of seeds. The last patch of land is about $70 \mathrm{mu}$ in size.

It seems that the actual abodes of Khara-Khoto peasant families are scattered around the farmland of the households. With this rather odd picture, one cannot but imagine the legacy of herding as factor of influence on the practice of building lodgings across pastures. Clearly, the structure and architecture of the quarters in rural Khara-Khoto is different from farming villages in the Central Plains. In most times, peasant families in a Chinese village cluster around a common residential quarter, whence they venture out into their respective farmlands during the day, which scatter onto the outskirt of the settlement. In contrast, Khara-Khoto residences are found scattered right on the family farmlands, like stars in a constellation or pieces on a chessboard. This curious phenomenon is extremely helpful when it comes to studying the farming community and farmland management in the agricultural hub of historical Khara-Khoto.

The first generations of the Dangxiang Tanguts were herdsmen who chose their dwelling places whither their herds roamed, and wherever pasture and water there were for cattles to graze. Since herding took place across vast grassland, individual households lived in felt tents as a mobile, single unit, at a large distance from other families. Although the peasants in Khara-Khoto had adapted to the settled economic life of agriculture, they still preserved some degree of the scattered settlement, with its roots in hunting and herding. At any rate, it must be noted that the Tanguts' conversion to agriculturalism was never to the point of totality. Most Tangut peasants engaged in tilling and pasturing at the same time, and maintained interests in animal-husbandry despite their reduced mobility. Families owned various numbers of livestocks. The family in the household record Инв. No. 8203 manuscript, for example, owns as many as three camels, 10 cattles, and 8 о sheep. In the Инв. No. 7893-9 record, the household keeps an impressive 3 horses and 32 camels. In one of our land sales

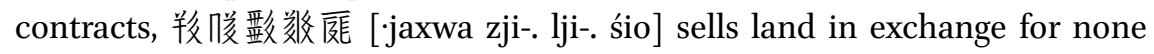
other than more livestocks. It shows that agriculture and animal-husbandry 
were intertwined and integrated. Scattered settlement is especially suited to an industrial structure of integrated agriculture and livestock-raising, and to the economic life of simultaneous farming and pasturing. Finally, given the spacious farmland in the relatively sparsely-populated Khara-Khoto, it was much easier for the families to manage their properties if they lived right on their own land.

As a matter of either strategy or practicality, to sell the fixtures along with the land clears the sale and cuts out complications at the single stroke of a deal. It is also much easier if the new landowner takes over the management of the properties immediately. It would be troublesome, for example, for the new landlord to lease the land out without the houses and yards.

\subsubsection{Four Borders and Neighbouring Farmland}

All Tangut land sale contracts hitherto found demarcate the four borders of the land near the end of the document, in order to specify the locations and direction of the land with precision. The common expression for demarcation

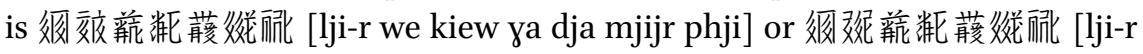
njijr kiew ya dja mjijr phji]: the four borders are clearly specified. The short sentence is followed by the neighbouring lands or locations to the east, south, west, and north of the patch of land to be sold. It could either be a private land of a neighbour, or a certain canal.

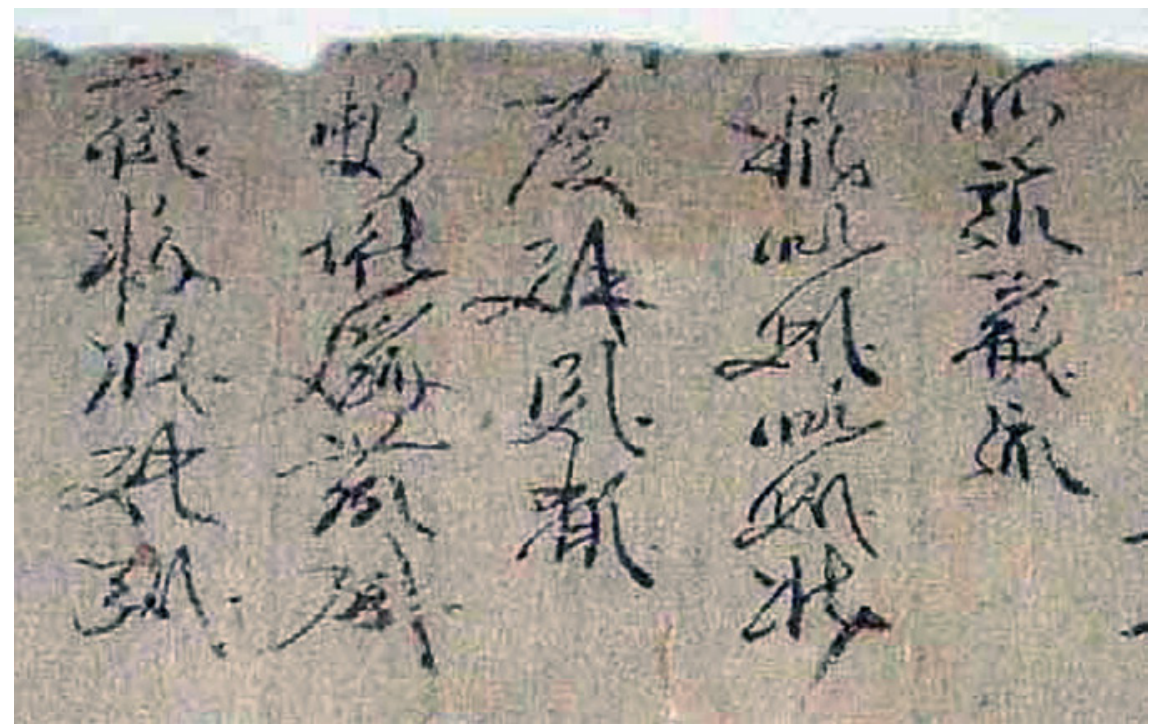

FIGURE 160

Инв. No. 4193: Wuwu fifth year of Tianqing (1198) four boundaries of the land specified in the contract of land sale 
It is remarkable that given the information on land demarcation near the end of the contracts, it is possible to map out the neighbouring lands along their borders, their direction and location relative to the canals and government-owned land. With 5 interrelated contracts, it is possible to sketch the following diagram:

CHART 12 Reconstructed diagram representing the location of farmland in Khara-Khoto

\begin{tabular}{|c|c|c|c|c|}
\hline \multirow[t]{3}{*}{ 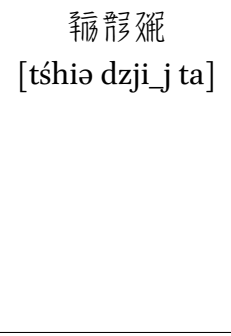 } & \multirow[t]{2}{*}{$\begin{array}{c}\text { 嚆荊婲 } \\
\text { [tśhiə dzji_j ta] }\end{array}$} & \multirow{4}{*}{$\begin{array}{l}\text { Canal } \\
\text { Pudao } \\
\text { Canal }\end{array}$} & 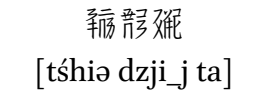 & \\
\hline & & & 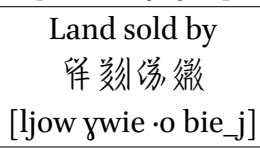 & $\begin{array}{c}\text { 蕧後孫隊 } \\
\text { [dju. dju. gju_·o] }\end{array}$ \\
\hline & \multirow{2}{*}{$\begin{array}{c}\text { 留㸘拼茫 } \\
\text { [ljow da kia } \\
\text { dju] }\end{array}$} & & \multirow{2}{*}{$\begin{array}{c}\text { Land sold by } \\
\text { 留绫恲務 } \\
\text { [ljow da kia ·jiw] }\end{array}$} & $\begin{array}{c}\text { 觢㸚耕荊 } \\
\text { [ljow gju_rjur śji-j] }\end{array}$ \\
\hline \multirow[b]{2}{*}{ 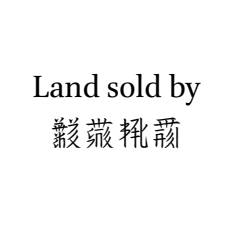 } & & & & \multirow{2}{*}{$\begin{array}{l}\text { Government- } \\
\text { Owned Land }\end{array}$} \\
\hline & \multicolumn{2}{|c|}{$\begin{array}{c}\text { 挈後恲哆 } \\
\text { [ljow da kia .jiw] }\end{array}$} & 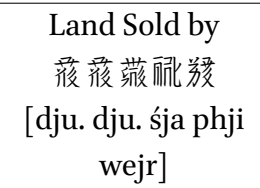 & \\
\hline \multirow{3}{*}{$\begin{array}{c}\text { 年父拼茫 } \\
\text { [ljow da kia dju] }\end{array}$} & \multirow{3}{*}{\multicolumn{2}{|c|}{$\begin{array}{c}\text { 㸷涤鍰 } \\
\text { [ljow lji-. wejr] }\end{array}$}} & $\begin{array}{c}\text { 蕧後效甛 } \\
\text { [dju. dju. gju_·o] }\end{array}$ & \multirow{2}{*}{$\begin{array}{c}\text { 徊粧 } \\
\text { [ywe zjwi.] }\end{array}$} \\
\hline & & & 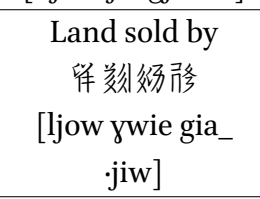 & \\
\hline & & & 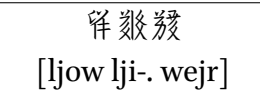 & $\begin{array}{l}\text { Government- } \\
\text { Owned Land }\end{array}$ \\
\hline
\end{tabular}

The diagram should by no means be taken literally at its face value. For a historically accurate demarcation of farmland, forever irrecoverable, could not have been made of neat squares and rectangulars. But for now, the graphical representation serves our purpose and aids our understanding of where the families are, and what land they sell. Apart from private farmland, there is also government-owned land. In addition, there is also land owned by Buddhist temples. It should be said that individual historical land sale contracts surviving to this day are precious finds. But a series of contracts where multiple patches of neighbouring lands are sold, wherewith it is possible for 
historians to reconstruct the landscape of historical farmlands, canals, and government-owned land, is even more valuable.

\subsubsection{Canals and Water Supply}

Names of local canals are mentioned in Tangut land sale contracts, especially in the demarcation of the land. These references provide key sources on Tangut irrigation system in Khara-Khoto area. The contracts mention a number of canals: the End of the Left Canal (被綃拜裙 [gju mji_j tsow gju]), 139

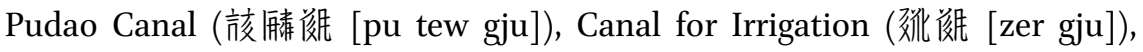
Government-owned Canal (㣪终 [kow gju]), Canal from the Hillside of Four

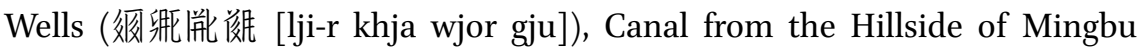

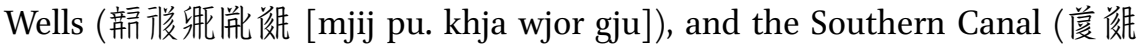
[zji-r gju]). One could see the complexity of the Khara-Khoto irrigation system. Some of the canals are owned and managed by the government. Others, such as Pudao and Mingbu, are named after Tangut tribes and families. As for whether they are privately owned, there is no settled conclusion without further evidence. Still, other canal names contain geographical references, such as the Southern or the Left Canals. There is much to be researched about these directions, and about the names of localities such as the Hillside of Four Wells. But we are reminded of canal names in Khara-Khoto Household Registers,

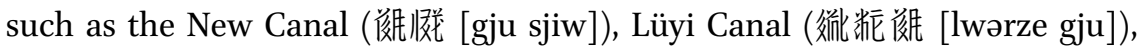

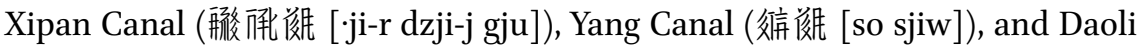

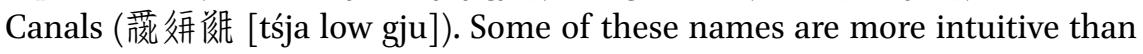
others. But again, much research remains to be done.

In 7 of the 8 land sale contracts, there is a concise, two-character or three-character expression right underneath the land tax, which is easy to overlook. The phrase has little to do with the text that comes immediately before or after, and therefore seems even a bit out of place. For example, in the

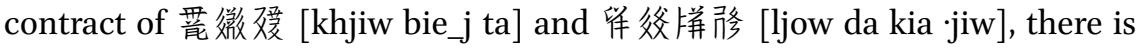

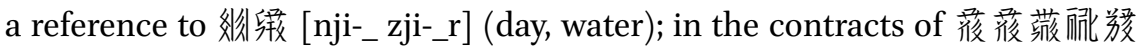

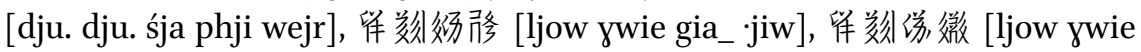

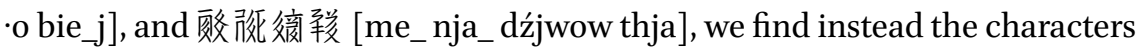

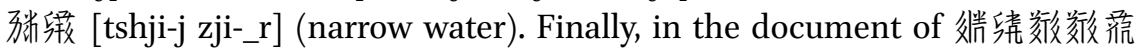
[phjij śjo sjwi sjwi dju], there are three characters: 傕䉺瓦 [zji-_r tshji-j khwo] (narrow water, half).

139 TN: The third character transliterates a number of loan words. It could be "left" or another name. 

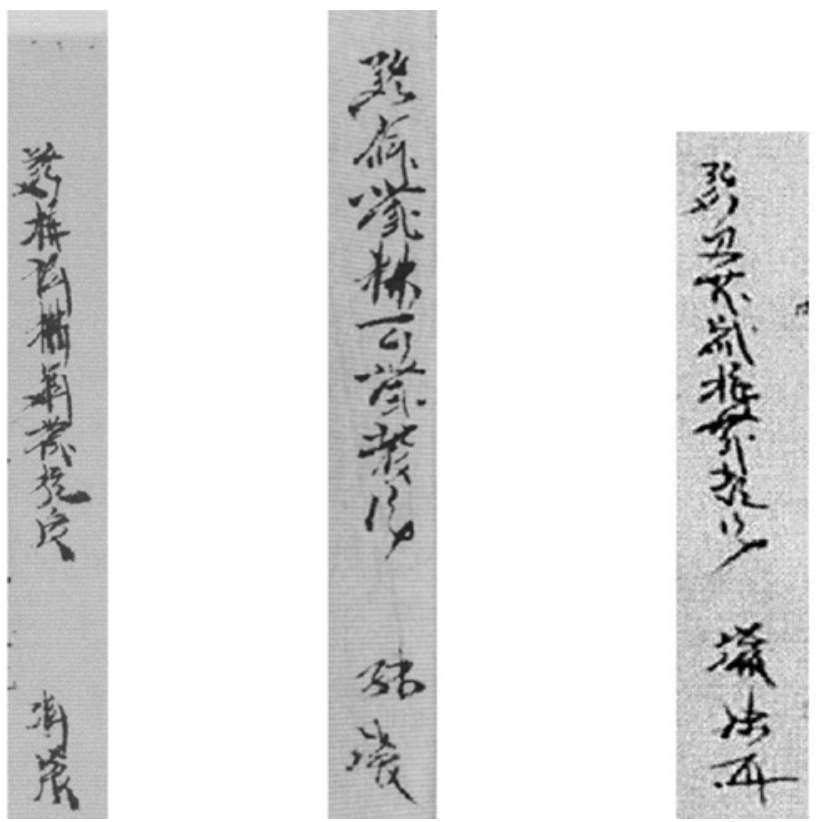

FIGURE 161

Инв. No. 5124: 'daily water' 'slim water' 'half slim water' under tax information in different land sale contracts

These are references to the amount of water supply required to irrigate a given patch of farmland. A comparative survey of the water supply data across multiple contracts shows a strong correlation between the land size (hence value) and the water supply for irrigation. For instance, the land of 無微嫹 [khjiw

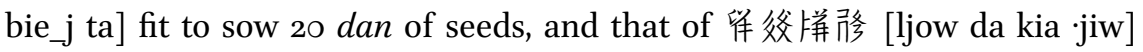
fit for 15 dan of seeds, both require a "daily" dose of water irrigation. By comparison, the patch of land sold by 後後带船婹 [dju. dju. śja phji wejr], fit to sow 8 dan of seeds, by 傕刻徍捐 [ljow ywie gia_.jiw] for 10 dan of seeds, by

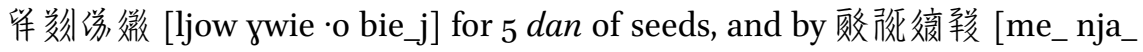
dźjwow thja] for 15 dan of seeds, all use "narrow" water for irrigation. 徏华糸 徬茫 [phjij śjo sjwi sjwi dju] states in his contract that a a "half-narrow" supply suffices for his land, where only 5 dan of seeds are sowed in a typical farming season. So, the general rule is exactly what anyone would expect, a positive correlation between farmland size and the amount of water supply. But there is a certain degree of variability within a certain range of land size, perhaps due to other factors of influence. In the macroscope, these references reveal the open secret that Khara-Khoto farmland relied almost exclusively on canals for irrigation, and that water is distributed largely according to the size of land owned by local households. 
In Book 15 of the Laws of Heavenly Prosperity, there are laws on "opening canals in the spring," "raising pastures and monitoring the waters," "canal waters," "various crimes related to land and water." All 5 items in the section on "raising pastures and monitoring the waters" are lost. The surviving content on canals and water are mostly to do with the management of irrigation systems. There is no explicit reference to the various levels of water supplies in the laws, nor definitions of such terms as "daily," "narrow," and "half-narrow." How exactly was water quantified, classified, and supplied to farmland, are first seen, and only to be reconstructed from land sale contracts.

\subsubsection{Government-Owned Land vs. Private Land}

There are both privately-owned and government-owned lands in Western Xia. Government-owned land, either farmland or pasture-land, is the property of the royalty, or assets under the proprietorship of the Department of Farmland (Agriculture). Government-owned farmland is still cultivated by peasant households. They turn in a portion of their yields after each harvest. Private land is owned legally by private households. These lands are managed by individuals and their families, or leased out to others. Those who tend to their own land pay taxes to the state, whereas those who survive on land lease pay rents to the landlords, who in turn pay taxes to the government. More than a few times, the Laws of Heavenly Prosperity refers to "government and private land," emphasising that "government and private lands should be separated"; "let government and private lands not be confused and mixed up" or exchanged at will. ${ }^{140}$

The government-private distinction is also apparent in land sale contracts. The contracts stipulate that the seller, rather than the buyer, assume full liability, should any transfer or lease of title occur, "either publicly or privately." This provision is intended to warn individuals against selling land illegally appropriated from private or government properties, which typically leads to a legal dispute. In addition, "government land" is frequently referenced in the demarcation of lands with respect to their four borders. The properties of $\frac{m}{\text { m }}$

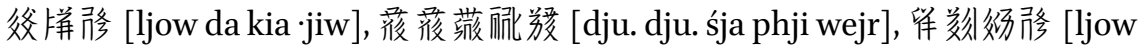

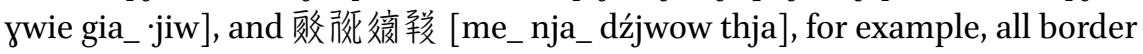
government-owned lands.

All land sold in these private contracts must have been privately owned. The previous owners are the sellers, and upon the signing of the contract, the

140 Revised Laws of Heavenly Prosperity 15, "Opening Canals in the Spring"; "Raising the Pasture and Supervising Irrigation"; "Canals and Waters"; "Miscellaneous Crimes Related to Land and Water," pp. 496-509. 
buyers become the new landlords: 羓䐘椂定 [-jaxwa mji-_tshja] (1 patch of land), Pudu Temple (8 patches of land), 篟被羰爰 [ljow tśju. 'wejr śjow] (3 patches of land). Naturally, with the transfer of titles, the new owners take over tax obligations, as well.

\subsubsection{Ripe vs. Unripe Land}

The Tanguts also distinguished between 'ripe' and 'unripe' land. 'Ripe' land refers to land already tilted and cultivated. The Laws of Heavenly Prosperity, for example, warns workers in canal projects against impairing ripe farmlands. ${ }^{141}$ 'Unripe' land refers to untitled or unfertile land that falls under neither private nor government proprietorship. The Tangut government encourages the cultivation of unripe land, and incentives peasants to reclaim wasteland with three years of tax exemption. The Laws of Heavenly Prosperity states that:

Where the many are not capable of cultivating a patch of land, and for this reason abandon it for three years without generating any tax, labour, or hay, whereupon the land is considered neither privately-owned nor government-owned; if then, the many wish to hold and cultivate it, let them report their intention to the Bureau of Transfer and Transportation. Let the staff consult the neighbouring heads of households who own properties that border the land concerned, and thereupon, after extensive and exhaustive examinations, let the staff inform the previous owner of the abandoned land of the present state of affairs. If all are true as they are alleged, let the staff issue a statement of cultivation to the concerned party, permitting it to farm the land, and record this in the official files. In three years' time, let the bureau dispatch another round of staff and officers to inspect and measure the outcome and output. Given the state of the seedlings and the measurements of tax in neighbouring lands, let the staff determine to which of the five levels of quality this farmland belongs. Then, let the land be taxed at the appropriate level. Within the same year, let this also enter the record of the files, as previously mentioned. Let the quantity of tax, labour, and hay be determined according to the laws along the frontiers, etc. ${ }^{142}$

There is a similar distinction between 'ripe land' and 'grassland' in the Song Dynasty. The Extended Zizhi Tongjian records that "reports from Youzhou: within 10 li outside the city walls, there are ripe lands. In another 1o li further

141 Revised Laws of Heavenly Prosperity 15, "Canals and Water," p. 502.

142 Revised Laws of Heavenly Prosperity 15, "On Taking Unused Land," p. 492. 
on the outskirt, there is uncultivated grassland."143 At that time, Youzhou was a border city between Song and Xia.

The land is labeled as 'ripe or unripe' in 6 of the 12 Khara-Khoto land sale contracts. The expression is 研纸 [ślo_w śijj] in Tangut, which may be a loan word from the Chinese 熟生. Since the Dangxiang Tanguts for a long time knew little about agriculture, there is no reason to have the word for "ripe/unripe" land in the native tongue. Only when a part of the Tangut population embarked on agriculture, did they borrow the concepts of the ripe and the unripe from Chinese peasants. Then the question is how ripe or unripe is 'ripe/unripe'? Given that the landowners are paying taxes as recorded in these contracts, the land must have been yielding grains past three years of tax-exemption. This would have been impossible had they been untitled or barely cultivated. 'Ripe or unripe' may refer to unfertile land that is nonetheless yielding harvests and taxes. ${ }^{144}$ It is possible that over time, the expression congealed and morphed into a term, wherewith the buyers expressed their personal likings and dislikings of the land. In that case, it would not have necessarily been an evaluation of the land's fertility.

\subsubsection{Price of Farmland}

In a society of private property, land price is one of the most important commodity prices in the economy, for it interlinks with various aspects of the society. In Western Xia, especially, land tax is the main source of government revenue. Therefore, land price has to do with national income and the peasants' livelihood. In Chinese sources, however, there is barely any record on Tangut land price or land tax. For this and many other reasons, Tangut land price and tax data in sell and purchase documents are of real significance to the study of the Tangut society.

At least in the surviving land sale contracts, land is traded not in cash, but

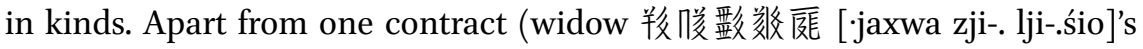
land sale contract), where the land is exchanged for livestocks, all other buyers purchase their land by grains. The contract lists the size of the land and the quantity of grains, so it is no difficult task to calculate the land price in terms of grains (usually in dan) per mu. But because the land comes with a variety of fixtures ranging from houses to trees and tools, the task is much more complex

143 Zi Zhi Tong Jian, Bk. 436, 4th year of Yuanyou in Zhezong Emperor's Reign (1089), Jiazi, 12th month of the year.

144 TN: That is to say, 'ripe and unripe' is more 'unripe' than 'ripe.' I think this could have been a derogatory term that the buyer leverages as a rhetorical instrument to deflate the value of the land in the negotiation process. 
if it were to render the calculation accurate. Furthermore, the quality and fertility of land varies widely. Lands also differ in terms of whence and how much water is required for irrigation. Yet another factor of complication is a difficulty with which we are not unfamiliar, that land size is often given in terms of the amounts of seeds to be sowed in it. The conversion from seeds needed to the actual size in mu turns out to be rather elastic. For all these reasons, accuracy cannot be fully achieved.

Since land sales without additional asset involved are much simpler and more straightforward, let us first try to derive some land prices from contracts of land sale without fixtures. Of the eight in total, there are two such simple contracts, which could provide the basis for our analysis. On the second day of the second month in the Year of Yin, 倠刻㣢徽 [ljow ywie $\cdot$ o bie_j] sells a patch of land where 5 dan of seeds may be sowed in the farming season (approximately $50 \mathrm{mu}$ in size) at the price of 4 dan of wheat and 9 dan of coarse grains.

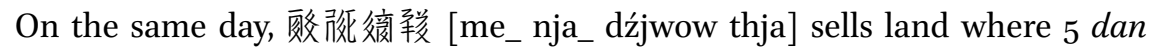
of seeds may be sowed, (likewise, around $50 \mathrm{mu}$ ) for 6 dan of coarse grains and 1 dan of wheat. Earlier in the book, we have derived the price of wheat in Khara-Khoto as somewhere between 200-250 mace, and the price of millet (a type of coarse grain) as 150-200 mace, both from fragments of Tangut grain sale accounts. ${ }^{145}$ That is to say, the unit price of coarse grains falls within $75 \%-80 \%$ that of wheat. If we convert the 4 dan of wheat in the first contract to about 5 dan of coarse grains, we then have the price at which the land was sold: 14 dan of coarse grains in total, or $2.8 \mathrm{dou}$ of coarse grains per $m u$. The same could be done to in the case of the second contract. Convert the 1 dan of wheat to 1 dan 3 dou of coarse grains. This way, the total price turns out to be 7 dan 3 dou of coarse grains, or 1.46 dou of coarse grains per $m u$.

So far, we have derived two unit-prices of Khara-Khoto land: 2.8 dou of coarse grains per $m u$ versus $1.46 \mathrm{dou}$ of coarse grains per $m u$. The land size in both cases are identical, and yet the prices are so far apart: a whopping $50 \%$ in difference. Perhaps the difference lies in their locations. The land of 经刻㣢徽

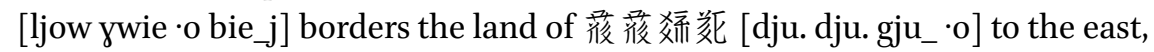
the land of 倠㸘恲胳 [ljow da kia jiw] to the south, the canals to the west, the

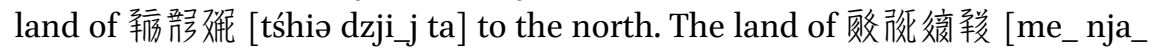
dźjwow thja] borders government-owned land to the east and the south, the

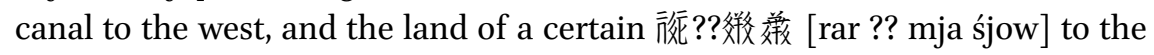
north. Both lands face the canal to the west. The key difference seems to be that the cheaper land borders government-owned land to the east and south.

And of the four separate, single-page contracts, two record the sales of land and houses only, without more complex assets. In the Bingchen Year of

145 Shi Jinbo, 2008. 


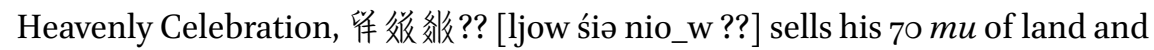
house for 5 dan of coarse grains- that is a mere 0.7 dou per $m u$. This is the lowest unit price recorded in any of the surviving contracts. In the Gengshen year of Heavenly Celebration, 峬荾|信良 [lew śji thow pha ] sells land fit to sow 100 dan of seeds, about $1000 \mathrm{mu}$ in size, at the price of 200 dan of coarse grains, or the unit price of 2 dou per $m u$.

Four of the contracts in the long scroll record transactions of land along with houses, yards, and additional assets. Because it is not easy to pin down the specific values of these properties, there is no reliable way to calculate the land price. If we simply ignore these assets, and focus only on the land, we derive the following prices: On the 24th day of the 1st month in the Yin Year of Heavenly Celebration, 罯徽嫒 [khjiw bie_j ta] sells his land fit to sow 20 dan of seeds, along with his yard, house, and cabins, altogether for 15 dan of coarse grains and 15 dan of wheat $=34$ dan of coarse grains, at the unit price of $1.7 \mathrm{dou}$ per $m u$; On the 29th Day of 1st Month in the Yin Year of Heavenly Celebration, 经终拼務 [ljow da kia jiw] sells land fit for ${ }_{15}$ dan of seeds, along with houses, trees, and stone graves, for 6 dan of wheat and 10 dan of coarse grains $=18$ dan of coarse grains in total, at the unit price of 1.2 dou per mu; On the same day, 後 後带配并爱 [dju. dju. śja phji wejr] sells land fit for 8 dan of seeds, along with 2 houses and 5 live trees, for 4 dan of wheat and 6 dan of coarse grains $=11$ dan of coarse grains, at the unit price of 1.37 dou per mu; on the 1st day of the 2nd

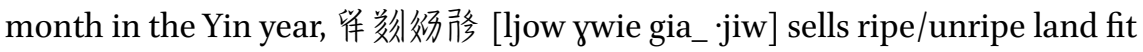
for 10 dan seeds, along with houses and walls, at the price of 2 dan of wheat, 2 dan of millet, and 4 dan of grains $=8.6$ dan of coarse grains, at the unit price of 0.86 dou per $m u$. There is an additional contract of land transaction where large assets are involved. So, at least there, it is easy to explain the high price in the light of this confounding factor. On the 1st day of the and month in the

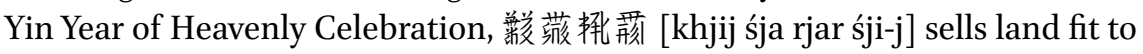
sow 10 dan of seeds, along with infrastructures, tools, and trees, all for 15 dan of wheat, 10 dan of coarse grains, and 10 dan of millet = 40 dan of coarse grains in total. It does seem that the additional assets weigh heavily in land pricing.

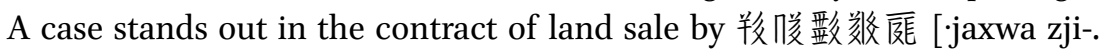
lji-síio] in the 22nd year of Heavenly Prosperity, where the widow sold her land for neither cash nor grains, but livestocks, rather than cash or grains. So, at least at the first glance, we cannot derive a price that is comparative to the other transactions. However, we have the general price of Tangut livestocks from a comparative analysis of the Laws of Heavenly Prosperity and data in the Khara-Khoto Livestock Sale contracts: a camel is worth about 6 dan of coarse grains; 1 ox is worth around 4 dan of coarse grains. ${ }^{146}$ Now, 䍩䐘政数庭

146 Ibid. 
[-jaxwa zji-. lji-śio] sells land for 2 full-teethed camels, 1 two-teethed livestock, 2 old ox. First, the two camels are worth 12 dan of coarse grains. If we take the two-teethed animal to be some bovine, then the cattles are worth altogether 8 dan of coarse grains. In this way, we convert the value of the 4 livestocks to approximately 20 dan of coarse grains. This number could be verified based on the penalty fee for breaching the contracts. Khara-Khoto contracts usually specify that the party reneges on the transaction be punished twice the amount of the sell \& purchase price. In this contract, the penalty fee is 30 dan of wheat, which means the transaction price must have been around 15 dan of wheat, or 20 dan of coarse grains, which is precisely the number derived from livestock prices. If we suppose for a moment that the assets are evenly distributed across the land to which they are attached, we could say that the price per $m u$ of land is around 1 dan of coarse grains. Now, the exorbitant price is possibly due to the assets that come with it, or because land price in the era of Heavenly Prosperity - about 20 years prior to the other contracts - was simply much higher. Another separate contract was signed in the fifth year of

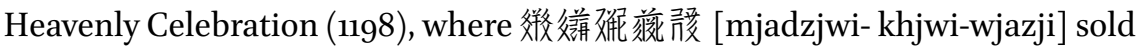
$23 \mathrm{mu}$ of land along with his yard and houses, all for 8 dan of coarse grains. The unit price is at 3.5 dou per $m u$ of land, which is rather high, as well. Likewise, we could pinpoint the properties as the causal variable. Below is a chart that compiles the data from all 12 contracts of land sales (all register numbers are in Инв. No.). ${ }^{147}$

CHART 13 Statistics on size and value of land in land sale contracts

\begin{tabular}{|c|c|c|c|c|c|c|}
\hline No. & Register & Date & Seller & $\begin{array}{l}\text { Land size } \\
\text { (seeds/mu) }\end{array}$ & Value/Price & $\begin{array}{l}\text { Assets and } \\
\text { Fixtures included }\end{array}$ \\
\hline 1 & 5010 & $\begin{array}{l}\text { Gengyin, } \\
\text { 22nd year of } \\
\text { Tiansheng }\end{array}$ & 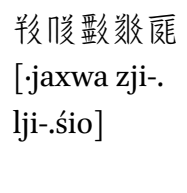 & $\begin{array}{l}\text { Ripe/ unripe } \\
\text { land for } 2 \\
\text { dan of seeds }\end{array}$ & $\begin{array}{l}2 \text { full-teethed } \\
\text { camels, } 1 \text { two- } \\
\text { teethed, }{ }^{\text {a }} \\
1 \text { old ox }\end{array}$ & $\begin{array}{l}\text { Yard, } 3 \text { thatched } \\
\text { cottages, } 2 \text { trees, } \\
\text { etc. }\end{array}$ \\
\hline 2 & $5^{124-2}$ & $\begin{array}{l}\text { 24th day of } \\
\text { 1st month, Year } \\
\text { Yin of Tianqing }\end{array}$ & 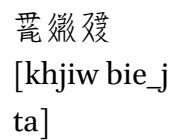 & $\begin{array}{l}\text { Ripe/ unripe } \\
\text { land for } 20 \\
\text { dan of seeds }\end{array}$ & $\begin{array}{l}\text { Coarse grains } \\
15 \text { dan, wheat } \\
15 \text { dan }\end{array}$ & $\begin{array}{l}\text { House and yard, } \\
\text { full set of } 4 \text { cabins }\end{array}$ \\
\hline
\end{tabular}

a The expression in the original text is: "there exist two [vertical things]," which might refer to a livestock that has grown two vertical teeth. It is a way of indicating the age of the animal.

147 TN: No. 1-12 correspond to Figures 148-159. 
CHART 13 Statistics on size and value of land in land sale contracts (cont.)

No. Register Date

Seller

$\begin{array}{lll}\text { Land size } & \text { Value/Price } & \text { Assets and } \\ (\text { seeds } / \mathrm{mu}) & & \text { Fixtures included }\end{array}$

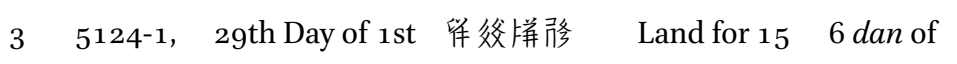

Yard, house, trees,

5124-3 Month, Year Yin [ljow da kia dan of seeds wheat,

stone grave, etc.

(4)

of Tianqing .jiw]

10 dan of

coarse grains

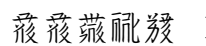

Land for 8

4 dan of

2 houses, 5 live

(5) 1st Month

[dju. dju.śja dan of seeds

phji wejr]

wheat, 6 dan trees

of coarse

grains $^{\mathbf{b}}$

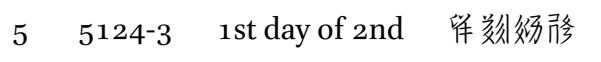

(10) month, Yin Year [ljow ywie

Land for 102 dan of

House, wall

gia_.jiw]

dan of seeds

wheat, 2 dan

of millet, 4 dan

of grains

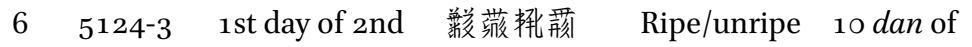

Cabins large

land for 10 wheat, 10

and small, tilling

(1)

month, Yin Year [khjij śja rjar

dan of seeds

dan of coarse

tools for oxen,

grains, 10 dan

stone gate with

of millet

bamboo fence,

pentamerous

yokes, tree yard

7 5124-3 2nd day of 2nd 倠䊽㣢微 Land for 5 4 dan of

(3), month, Yin Year [ljow ywie ·o dan of seeds wheat, 9 dan

5124-4 bie_j] of coarse

(1)

$8 \quad 5124-4$

(3)

2nd day of

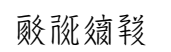

Land for 5

grains

2nd month, Yin [me_nja_ dan of seeds

Year

dźjwow thja]

6 dan of coarse

grains, 1 dan

of wheat

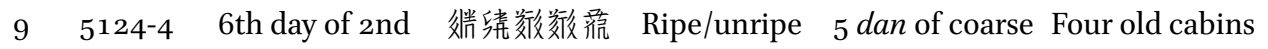

(10) month, Year Yin [phjij śjo sjwi land for 3 grains

of Tianqing sjwi dju] dan of seeds

b TN: Due to a typological or typesetting error, the input for price here erroneously shows assets (houses \& trees) in the Chinese edition of the book, p. 278. 
CHART 13 Statistics on size and value of land in land sale contracts (cont.)

\begin{tabular}{|c|c|c|c|c|c|c|}
\hline No. & Register & Date & Seller & $\begin{array}{l}\text { Land size } \\
(\text { seeds/mu) }\end{array}$ & Value/Price & $\begin{array}{l}\text { Assets and } \\
\text { Fixtures included }\end{array}$ \\
\hline 10 & 4199 & $\begin{array}{l}\text { 16th day of } \\
6 \text { th month, } \\
\text { Bingchenyear } \\
\text { of Tianqing }\end{array}$ & $\begin{array}{l}\text { 留㷋剂?? } \\
\text { [ljow śiə } \\
\text { nio_w ??] }\end{array}$ & $\begin{array}{l}\text { Ripe/unripe } \\
\text { land for } 10 \\
\text { dan of seeds, } \\
(70 \mathrm{mu})\end{array}$ & $\begin{array}{l}5 \text { dan of coarse } \\
\text { grains }\end{array}$ & \\
\hline 11 & 4193 & $\begin{array}{l}5^{\text {th day of } 1 \text { st }} \\
\text { month, Wuwu, } \\
5^{\text {th Year of }} \\
\text { Tianqing }\end{array}$ & 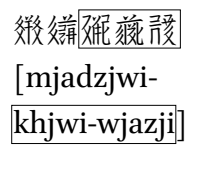 & $23 \mathrm{mu}$ & $\begin{array}{l}8 \text { dan of coarse } \\
\text { grains }\end{array}$ & Yard \\
\hline 12 & 4194 & $\begin{array}{l}\text { 22nd day of } \\
\text { 2nd month, } \\
\text { Gengshen Year } \\
\text { of Tianqing }\end{array}$ & $\begin{array}{l}\text { 㪰葼娮永 } \\
\text { [lew śji thow } \\
\text { pha ] }\end{array}$ & $\begin{array}{l}\text { Ripe/unripe } \\
\text { land for } 100 \\
\text { dan of seeds }\end{array}$ & $\begin{array}{l}200 \text { dan of } \\
\text { coarse grains }\end{array}$ & $\begin{array}{l}\text { Yard and abode, } \\
\text { full set }\end{array}$ \\
\hline
\end{tabular}

The prices above suggest that toward the late Tangut period, land price in Khara-Khoto remained as low as 2 dou of coarse grains per $m u$. The contracts are signed at times of great urgency and necessity. The buyers exploit of the sellers' shortage of grains to force the price down, in order to extract maximum surplus value.

\subsubsection{Farmland Tax}

\subsubsection{Farmland Taxes in the Contracts}

All holders of land titles in Western Xia have to pay land taxes to the government according to the laws. All the 8 land sale contracts of the long scroll record the amounts of taxes levied on the given patch of land. The typical formula is: "there are taxes in the amounts of $\times d o u$, of which there is wheat $\times$ dou $\times$ sheng." In Tangut, verbs are postpositional. So, the existential verb "there is" is found at the end, following the object. There are various kinds of existential verbs in Tangut, which serve to denote the different modes of existence of various kinds of entities. There are, for example, different existential verbs that denote the existences of things precious, internal, attached, parallel, belonging, or vertical. ${ }^{148}$ The existential verb used in land sale contracts to denote

148 TN: Shi, Jinbo and Li, Hansong. Tangut Language and Manuscripts: An Introduction. Leiden: Brill, 2020, pp. 317-354. 


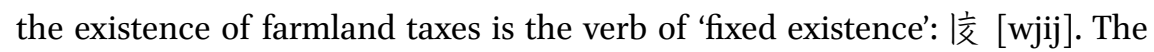
diction suggests that the tax rate here is fixed, or at least that it is fixed by the state, impermeable to changes of proprietorship. ${ }^{149}$

The amounts of taxes in the 8 contracts are as follows: 無徽横 [khjiw bie_j ta]: 1 dou of wheat and 4 dou of coarse grains $=5$ dou; 得父拼俢 [ljow da kia

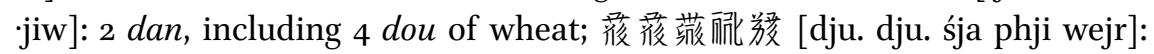

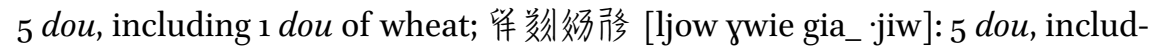

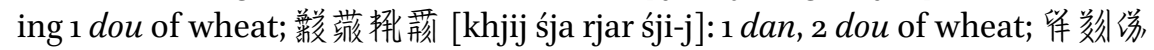

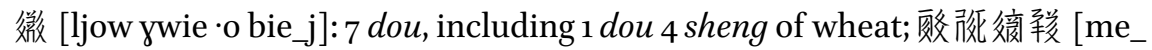

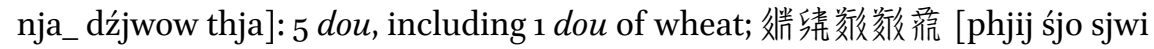
sjwi dju]: 8 dou of coarse grains, 2 dou of wheat.

None of the four separate contracts outside the long scroll document the land taxes in their precise quantities. But of them, the contract dated to the 16th day of the 6th month in the Bingchen Year of Heavenly Celebration states that "The burdens of obligations in all three forms of levies: tax, labour, and hay, fall on 聚效爰 [ 'wejr tśju. śjow].” This is a clear indication that upon completion of the transaction, the tax obligations are transferred along with the property to the new landlord.

At length, the Laws of Heavenly Prosperity elaborates on the procedures and practices of taxation. Laws on farmland taxes seem to concentrate in Book 15: "On Urging the Payments of Taxes," "Merits and Misdemeanors in Urging Tax Payments" etc. The laws set forth household obligations to pay various kinds of taxes, to turn in always the right amount, and to register tax payments with the government. ${ }^{150}$

The government rolls out extensive and exhaustive rules and regulations, primarily to ensure tax revenues. Whether the land is farmed, transacted, or leased, the rock of certainty and security, in the eyes of the empire, is the uninterrupted income from agricultural taxation. Therefore, it is imperative that contracts specify whether and how much taxes are levied on each patch of land. As the titles transfer from peasant households to the ownership of the Pudu Temple in Khara-Khoto, the tax obligations attached to the land are also transferred onto the new owner. It is a matter of great importance for both parties to specify this obligation in the contract.

The Laws of Heavenly Prosperity also stipulates the following:

Buddhist and Taoist monks, all the many officials of higher or lower ranks, if for public purposes seek farmland under the proprietorship of

149 TN: Ibid., pp. 330-334, 345, 347, 350-351.

150 Revised Laws of Heavenly Prosperity 15, p. 508. 
either the Department of Farmland, Monasteries, or the Royalties, let the transacting parties inform the Bureau of Transfer and Transportation within a year of the purchase's completion, so that the transaction may enter into government files and land records, and that affairs of tax, hay, and labour may proceed according to the laws. ${ }^{151}$

Western Xia installs Bureau of Transfer and Transportation offices across its territory, especially along the frontiers, to supervise farming and canal projects, to collect taxes, and to transport grains from one area to another. One such office is located in the city of Khara-Khoto. ${ }^{152}$

Tangut laws do not enumerate or elaborate on farmland tax rates. However, given the data on the size of land owned and the amount of tax paid by individual households in Khara-Khoto tax accounts, we arrive at a tax rate of 0.1 dou (or 1 sheng) of coarse grains, and 0.025 dou (1/4 sheng) of wheat per $m u .{ }^{153}$ Obviously, the Tanguts pay taxes at fixed rates, based on their farmland sizes. The rulers of Western Xia could have borrowed the tax system from medieval Central Plains, where it had been a standard practice. But it is in the Khara-Khoto contracts, more than anywhere else, that we see farmland tax at work.

\subsubsection{Land Taxes in Contracts versus Tax Documents}

The farmland tax rates derived from the 8 contracts in the long scroll may be tested against the tax rates available in Khara-Khoto tax accounts. For example, at the farmland tax rate derived from the accounts, 茏微横 [khjiw bie_j ta] should have paid 5 dou of grains for a land at least 5 o $m u$ in size. In reality, the actual land size as recorded in the contracts is enough for 20 dan of seeds, or around $200 \mathrm{mu}$. One could not but wonder what accounts for such huge dis-

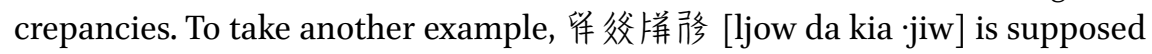
to have paid 2 dan of coarse grains for $200 \mathrm{mu}$ of land. The contract gives the actual land size as 15 dan of seeds, or $150 \mathrm{mu}$. Here, the numbers are much closer, but the discrepancy is there, nonetheless. Likewise, discprenacies are

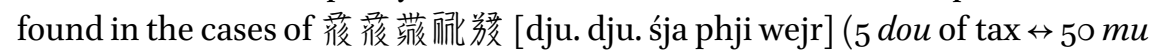
of land, versus $80 \mathrm{mu}$ of land $=8$ dan of seeds), 佯垓柪骆 [ljow ywie gia_-jiw] ( 5 dou of tax $\leftrightarrow 50 \mathrm{mu}$ of land, versus $100 \mathrm{mu}$ of land $=10$ dan of seeds), 篟数㣢 徽 [ljow ywie $\cdot \mathrm{o}$ bie_j] ( 7 dou of tax $\leftrightarrow 70 \mathrm{mu}$ of land, versus $50 \mathrm{mu}$ of land $=5$

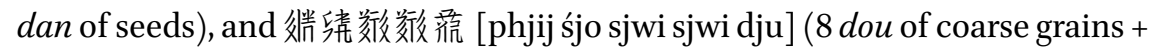

\footnotetext{
151 Ibid., p. 496.

152 Revised Laws of Heavenly Prosperity 10, pp. 368-375.

153 Shi Jinbo, 2005 (a).
} 
2 dou of wheat $=1$ dan of grains $\leftrightarrow 100 \mathrm{mu}$ of land, versus $30 \mathrm{mu}$ of land $=3$ dan

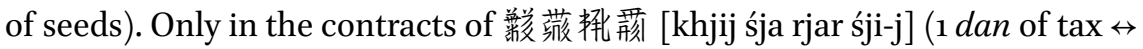

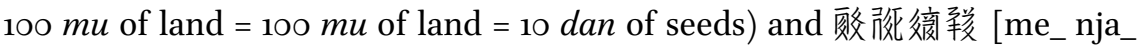
dźjwow thja] ( 5 dou of $\operatorname{tax} \leftrightarrow 50 \mathrm{mu}$ of land $=50 \mathrm{mu}$ of land $=5$ dan of seeds) are the expected and the actual land size found to be equal.

Only 2 of the 8 contracts match the tax rate derived from Khara-Khoto tax accounts. Several factors may account for the large and small discrepancies. First of all, given the greater abundance of farmland in Khara-Khoto, measurement is sometimes loose. After all, to measure land size by the amounts of seeds to be sowed there is in approximate terms. The idea that Khara-Khoto residents even thought it necessary to measure land in precise terms could be an anachronistic, or outright false assumption to begin with. After all, land size is registered in terms of seeds even in shoushi household reports. In the 8 contracts where land size is measured by seeds, the unit of measurement begins with dan, rather than dou. That means we are approximating land size in the units of $10 m u$ at a time. Precision is basically out of the question. But imprecise data cannot serve as the basis of tax calculation. Furthermore, variable land quality, relative 'ripeness' or 'unripeness,' or supplies of water and states of irrigation, could all lead to significant variations in the seeds vs. yields ratio. Therefore, tax on a given farmland is determined regardless of the amounts of seeds. Rather, tax depends solely on the expected yield. We already know from the afore-quoted passage in the Laws of Heavenly Prosperity that, upon three years of cultivation, officers would inspect the land, and assign it one of the five levels of fertility, whereby the tax rate in the future shall be determined. ${ }^{154}$ It turns out that the Tangut government cared not only about land size but also land productivity. Along this line of thinking, we find ourselves in a better position to unveil the mystery of tax rate discrepancies. Some farmland in Khara-Khoto are large in size, but are not particularly fertile. Therefore, farmers are granted the leniency of a lighter tax burden. And vice versa. This is why we should not have been calculating 'expected land size' based on the standard tax rate. In the Laws of Heavenly Prosperity, we also find the stipulation that "Heads of farming households in the seven counties in the vicinities of the imperial capital are to pay taxes according to five levels of land quality: highest: 1 dou per $m u$; secondary: 8 sheng; middle: 6 sheng; lower: 5 sheng; lowest: 3 sheng." 155 Even within nearby vicinities, land taxes could vary as much as

154 Revised Laws of Heavenly Prosperity 15, "Miscellaneous Crimes Related to Land and Water," 492.

155 Russian Collection of Khara-Khoto Manuscripts, vol. 8, pp. 300, 307, 301; see also, Pan Jie, 2012. 
three times, depending on perceived fertility and expected yield. Overall, land fertility in Khara-Khoto doesn't compare to the Hetao area near the capital. But one could easily see that large and diverse landscapes in Khara-Khoto cause tax variations.

There is also great consistency in Khara-Khoto tax accounts and land sale contracts. For example, in the document Инв. No. 1178, a land 1 qing $5^{\circ} \mathrm{mu}$ large is taxed 1 dan 8 dou and 7.5 sheng, including 1 dan 5 dou of coarse grains, and 3 dou 7.5 sheng of wheat; another patch of land 1 qing $43 \mathrm{mu}$ large is taxed 1 dan 7 dou 8 sheng 7.5 ge. ${ }^{156}$ It could be that these farmlands classified into the same level of quality. At least in Khara-Khoto tax accounts, the coarse grain to wheat ratio is $4: 1$, the same ratio as in land sale contracts.

\subsubsection{Guarantee of the Contracts \\ 3.1.6.1 The Force of Law in the Contracts}

Sell and purchase contracts acquire the force of law, as both parties voluntarily recognise and agree to enforce the terms set therein. Of all transactions, land transfer is an economic and legal activity of vital importance. Therefore, the terms of penalty against breach of contract are harsher, and written in greater details than in loan contracts. For this reason, all Khara-Khoto land sale contracts, without exception, specify penalty fees after recording the price.

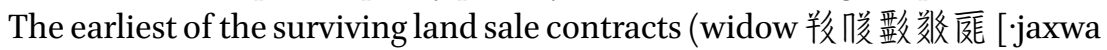
zji-. lji-śio], 22nd Year of Heavenly Prosperity) states that, should any dispute over the title arise, the seller 貉庭 bears all responsibility. If a party reneges on the contract, it will be prosecuted according to the Laws and Orders, as well as pay 30 dan of wheat according to the laws.

The long scroll goes to greater lengths. The contract of 罯微嫒 [khjiw bie $j$ ta] (24th day of the 1st month in the Yin Year of Heavenly Celebration) states that, upon signing the contract, neither the land nor the payment is overdue. Should any be any (illegal) transfer of land, either from the government or from a private individual, or should any dispute arise amongst members of the same chao, it is the seller 徽横, not 解爱靶 [dow dźjij phu_], responsible for the consequences. In cases such as these, recompensation is twice the purchase price. The reneging party bears all legal costs, and pays 2 liang of gold as a penalty fee, according to the laws. In other words, if the seller attempts to transfer a title that is not legally in his dominion - say, if he loaned it from the real proprietor, or appropriated it from the government-he would be punished for the criminal conduct. As for disputes, they are usually initiated by "members of the same chao" - these are family relatives, friends and comrades who may

$15^{6}$ Shi Jinbo, 2005 (a). 
lay a claim to common proprietorship or partial inheritance rights. Needless to say, should such a quarrel ever happen, the responsibility falls solely on the seller. He or she would be punished twice. First, it is necessary to repay twice the sum of the price. Sellers, mostly needy peasants desperate to refill their fast emptying granaries, are pressured into declaring that their "own hearts are willing," that is, they voluntarily agree to the term. But such a penalty would be unbearable to anyone, lest a peasant household. So, the whole purpose of adding this clause in the contract is to ensure the categorical prevention of the remotest chance that legal troubles might ensue. Then comes the penalty against the 'reneging party' for breaching the contract. On the surface of things, this clause applies to both the selling and the buying parties. However, given that the price is forced down to the minimum, the only party that would ever possibly regret is the seller. So, this clause is also better understood as a restraint on the seller. It is also worth noting that the penalty against unilateral withdrawal from the contract by a reneging party is in gold, rather than grains or a less valuable cash.

Penalty terms are more or less similar from one contract to another. Some note only that in disputes, the recompensation is double the sum of the price, but not penalty fees for a reneging party. 7 of the 8 land sale contracts in the long scroll specify penalty fees. The one exception is where the land is also the smallest. The penalty fee has to do with the volume of transaction, but without

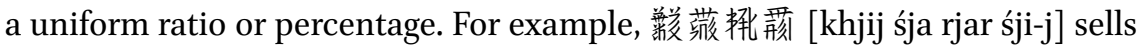
for a higher price: 15 dan of wheat, 10 dan of coarse grains, and 10 dan of millet. In this case, the penalty fee is a whopping 3 liang of gold. 䒴微㯖 [khjiw bie_j ta] is paid 15 dan of coarse grains and 15 dan of wheat. His penalty fee would

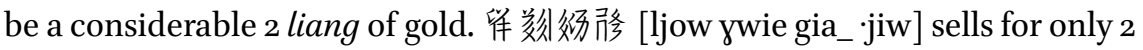
dan of wheat, 2 dan of millet, and 4 dan of grains. The penalty is 1 liang of gold.

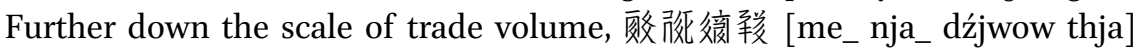
earns only 6 dan of coarse grains and 1 dan of wheat. His penalty fee is also 1

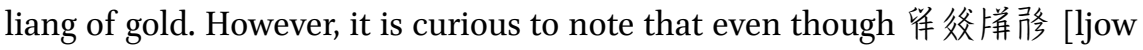
da kia ·jiw] sells his land and houses for a medium 6 dan of wheat and 10 dan of coarse grains, the penalty fee in his contracts is as high as 3 liang of gold.

In one of the individual land sale contracts, the volume of transaction by 姅 荾諒倠 [lew śji thow pha ] reaches 200 dan of coarse grains, but the penalty fee remains at 3 liang of gold. It could be that 3 liang is the maximum penalty

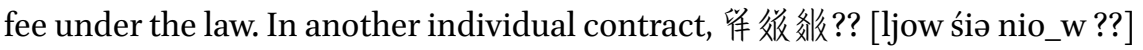
sells his land and houses for 5 dan of coarse grains. But his penalty fee is listed not in gold, but 10 dan of coarse grains. We could do the gold-to-grain the conversion here. A transaction of 7-8 dan of grains corresponds to 1 liang of gold as penalty fee. We know that the Tanguts customarily penalise demeanors by 
doubling the initial value. If that is true, then 1 liang of gold is worth $15^{-3} 3$ dan of grains. To set the penalty fee in gold is not a unique practice of the Tanguts. Penalty fees paid in gold are found in Dunhuang sell and purchase contracts. It is also worth noting that no corporal punishment, such as strokes, are seen in these Tangut contracts.

CHART 14 Terms of penalty for breaching the contract

No. Seller

\section{Land size Value/Price} (dan of seeds)

\section{Penalty in case Penalty for the of a dispute reneging party}

1 羓凌铔敬庭 Land for 2 full-teethed [.jaxwa zji-. lji-. 2 dan of camels, 1 two2 dan of penalty Penalty: 30 dan śio] seeds per 1 dan of of wheat

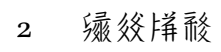
Land for teethed, 1 old ox payment

[lhju da kia gji] 15 dan of coarse 2 dan of penalty Penalty: 2 liang

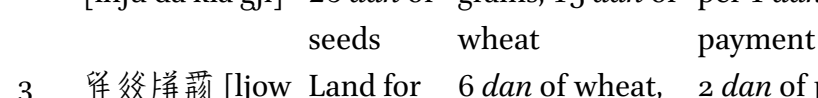
per 1 dan of of gold

3 倠父样茾 [ljow Land for 6 dan of wheat, 2 dan of penalty Penalty: 3 liang da kia 15 dan of 10 dan of coarse per 1 dan of of gold śji-j] seeds grains payment

$4^{\mathrm{a}}$ 㸷父拼務 [ljow Land for 4 dan of wheat, 2 dan of penalty Penalty: 1 liang da kia ·jiw] 8 dan of 6 dan of coarse per 1 dan of of gold seeds grains ${ }^{b} \quad$ payment

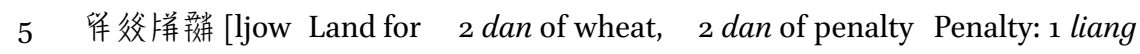
da kia phu_] 10 dan of 2 dan of millet, per 1 dan of of gold seeds 4 dan of grains payment

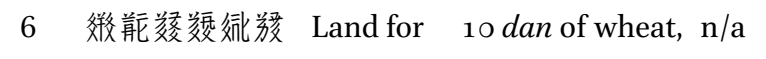
[mjadzow pji. 1o dan of 10 dan of coarse of gold phə tśhja wejr] seeds grains, 10 dan of millet

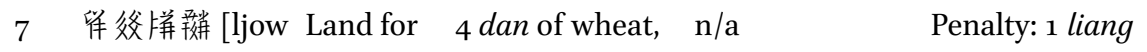 da kia phu_] 5 dan of 9 dan of coarse of gold

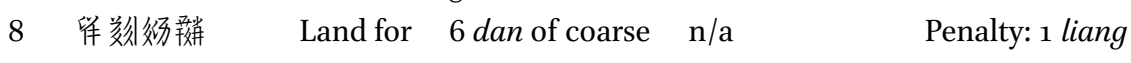 [ljow ywie gia_ 5 dan of grains, 1 dan of of gold phu_] seeds wheat

a TN: Erroneous numbering in the Chinese edition, p. 283.

b TN: Erroneous input in the Chinese edition, ibid. 
CHART 14 Terms of penalty for breaching the contract (cont.)

\begin{tabular}{|c|c|c|c|c|c|}
\hline No. & Seller & $\begin{array}{l}\text { Land size } \\
\text { (dan of } \\
\text { seeds) }\end{array}$ & Value/Price & $\begin{array}{l}\text { Penalty in case } \\
\text { of a dispute }\end{array}$ & $\begin{array}{l}\text { Penalty for the } \\
\text { reneging party }\end{array}$ \\
\hline 9 & 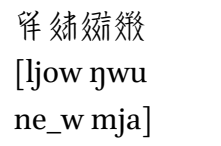 & $\begin{array}{l}\text { Land for } \\
5 \text { dan of } \\
\text { seeds }\end{array}$ & $\begin{array}{l}5 \text { dan of coarse } \\
\text { grains }\end{array}$ & $\begin{array}{l}\text { Penalty fee: } \\
5 \text { dan of wheat }\end{array}$ & \\
\hline 10 & $\begin{array}{l}\text { 倠㷋剂?? } \\
\text { [ljow śiə nio_w } \\
\text { ??] }\end{array}$ & $\begin{array}{l}\text { Land for } \\
\text { 1o dan } \\
\text { of seeds, } \\
70 \mathrm{mu}\end{array}$ & $\begin{array}{l}5 \text { dan of coarse } \\
\text { grains }\end{array}$ & $\begin{array}{l}\text { Penalty: } 10 \text { dan } \\
+2 \text { dan of compe } \\
1 \text { dan of payment }\end{array}$ & $\begin{array}{l}\text { f coarse grains } \\
\text { ensation per } \\
t\end{array}$ \\
\hline 11 & 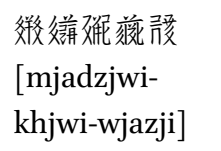 & $23 m u$ & $\begin{array}{l}8 \text { dan of coarse } \\
\text { grains }\end{array}$ & $\begin{array}{l}2 \text { dan of penalty } \\
\text { per } 1 \text { dan of } \\
\text { payment }\end{array}$ & \\
\hline 12 & 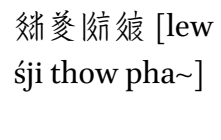 & $\begin{array}{l}\text { Land for } \\
\text { 1oo dan } \\
\text { of seeds }\end{array}$ & $\begin{array}{l}200 \text { dan of } \\
\text { coarse grains }\end{array}$ & $\begin{array}{l}2 \text { dan of penalty } \\
\text { per } 1 \text { dan of } \\
\text { payment }\end{array}$ & $\begin{array}{l}\text { Penalty: } 3 \text { liang } \\
\text { of gold }\end{array}$ \\
\hline
\end{tabular}

Besides, the Laws of Heavenly Prosperity is unequivocal on punishing the acts of reneging on promises and defaulting on debt:

When the many lend or sell their own shijun serfs, nupu servants, farmland, and houses to other parties, let them make contracts. When the pawned or mortgaged properties are not retrieved and the debt not yet covered, if the pawning party changes his mind, let the reneging party be punished a horse if he holds a title, or thirteen strokes if he is a commoner. If the pawned properties have been retrieved, but the pawning party claims otherwise, and in this way change his mind, let the case be judged, given the value of the properties retrieved, and in accordance with the laws on change of conduct in debt payment. If the pawn is not yet covered, but the party claims otherwise, out of the intention to claim it, or if the pawning price is accepted, but the accepting party claims otherwise, let him be tried on the same charges as in the change of conduct in debt payment. ${ }^{157}$

157 Revised Laws of Heavenly Prosperity 11, "On Hired Labour," p. 39o. 
The imperial laws guarantee the enforcement of all the terms set forth in Tangut sell and purchase contracts.

\subsubsection{Signature and Stamp}

Stamps and signatures are crucial to ensuring the accuracy and the reliability of the contracts. It is also a necessary procedural step in the legal formalism of the contract, symbolising the moment the text acquires its effectual legal force. An unsigned and unstamped contract is deemed as null.

As in Chinese contracts, signatures and stamps are found near the end of Tangut contracts. Typically, each signatory takes up a line. In rare cases, two witnesses could share a single line. In all surviving land sale contracts, the seller signs first, then the co-liable, followed by the witnesses. There could be up to two or more co-liable parties and witnesses. One easily notices that the fluent cursive style of Tangut calligraphy is consistent throughout the text, with no variation even between the signatures of Contract Parties and witnesses. In fact, not unlike grain loan accounts, land sale accounts are written not by the one of the principle parties, but by a professional transcriber. In the contract

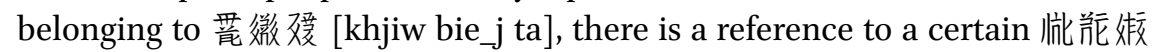

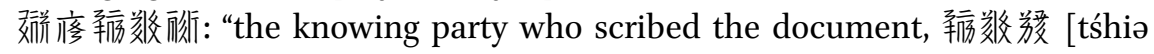
lji-. wejr]." Evidently, he is one of the witnesses to the contract, but also the one who wrote out the entire text. This is the first contract in the long scroll. Other contracts exhibit a nearly identical calligraphic style. So, it does seem that the

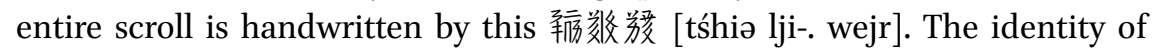
the man is impenetrable but not impervious to inference. Since long scroll is prepared by the Pudu Temple, and concerns land lease and purchase by the monastery, the main transcriber must have been arranged for by the temple, as well. The most accessible transcriber is one of the monks, who must have

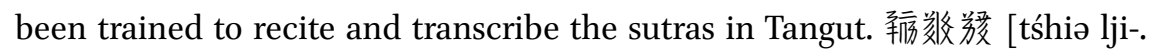
wejr] may well have been one of the literate monastics. The name 数嗳 (the prosperous mangala) itself also invokes Buddhist imageries.

Tangut contracts are signed in the collective presence of all involved parties: the seller, buyer, co-seller, transcriber, and witnesses. In general, the more land is sold, the more co-sellers and witnesses there are. The one selling the most land is 㸚荾信良 [lew śji thow pha ], who summoned 3 co-sellers, 4 witnesses.

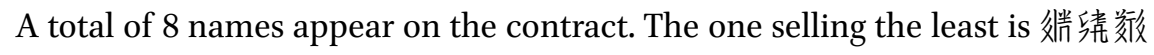
颜茫 [phjij śjo sjwi sjwi dju], with only 2 witnesses and no Co-contract Party.

A majority of Tangut contracts are unilateral: there is only one copy, held by one of the two principal parties involved in the transaction. The contract is drafted in the voice of the party requesting or initiating the transaction, usually the seller or the borrower. The party that keeps the contract in possession 


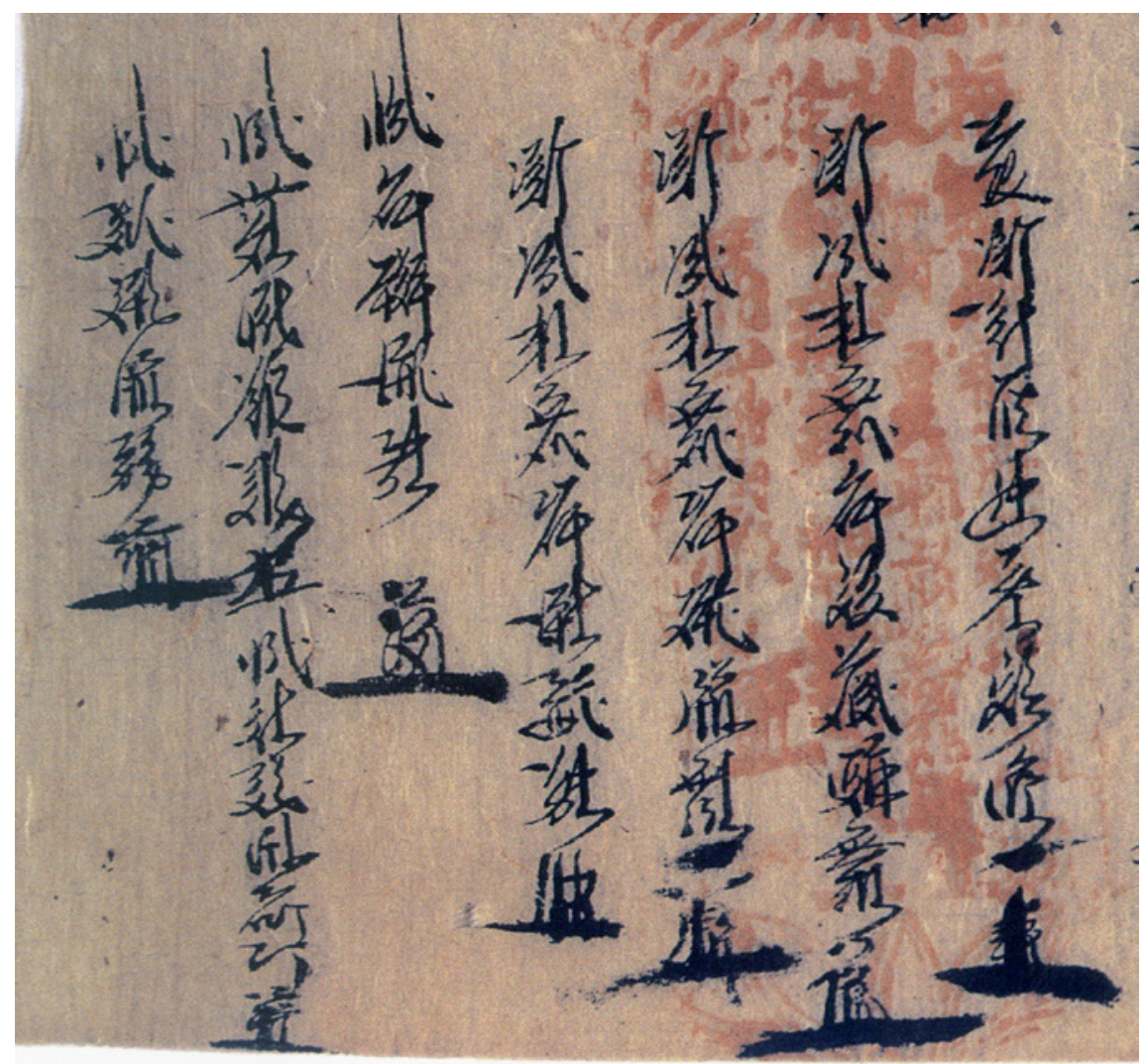

FIGURE 162 Инв. No. 4194: Gengshen year of Tianqing (1200) contract of land sale by 文迷荾 统永, signed and stamped

is the creditor or the buyer, whose name does not have to appear on the contract. Unilateral contracts are used for not only absolute sales, but also pawning, mortgaging, leasing, and loaning. They showcase the position of economic advantage of the buyer or the creditor. They are the side with privileges, whose rights are better secured. The seller or the debtors claim fewer rights, given their position of economic disadvantage. They are the party expected to fulfil a set of obligations. Or, it should be said that unilateral contracts is characterised by the system of partial obligation.

A unilateral contract cannot be authenticated by examination against a second original copy. For this reason, the signatures and stamps are the only way to ensure its authenticity. The signature of the seller begins with the title 萑骖 瓶疼 [·jwi-r dźiow wji mjijr]: “the one making the contract," i.e. the principle party to contract initiating the agreement. Sometimes, it is written as 鉉度 [źji. 


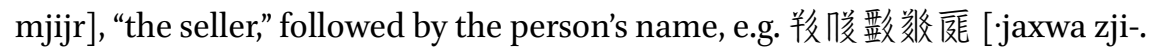
lji-śio]. The signature is not supposed to omit the surname, as in the main text.

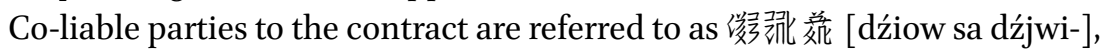
lit. "contract receiver," i.e. a co-contracting party. In sell and purchase contracts, the title is sometimes rendered 㻐㜿㫪䒵 [dźiow sa źji. dźjwi-], lit. “contract receiver-seller," i.e. the co-contracting seller. In fact, it could be further shortened to 叛䒵 [źji. dźjwi-], the "co-seller." In some contracts of land and house

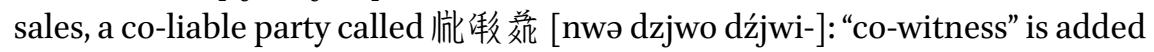
to the signatures of main and co-liable contracting parties. In most cases, liability-sharing parties to a contract are the family relatives of the main contract party: sons, wives, and brothers. This is to confirm that the sale is not an individual decision, but one made jointly or in consultation with the family. The presence of co-contracting parties ensures the restraining and authenticating power of the contract, thus rendering it more effective and enforceable. Precedents of this practice are found in some of the Dunhuang sell and purchase contracts. ${ }^{158}$

Should disputes arise, co-contracting parties share liability with the main party to contract. If the seller dies, escapes, or enters into exiles, the co-liable parties assume full or main responsibility. With the exception of 1 contract with a missing end, 10 of the other 11 contracts feature 2 or more co-contractors.

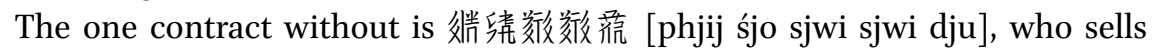
the least amount of land. The contracts make sure to indicate the relation-

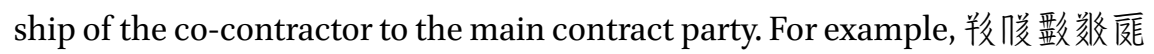
[.jaxwa zji-. lji-.śio]'s co-contractors are his “son, 捘峗烙勈 [mə rar ko tśjow]."

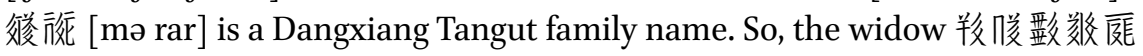
[.jaxwa zji-. lji-.śio]'s deceased husband must have been an Dangxiang ethnic

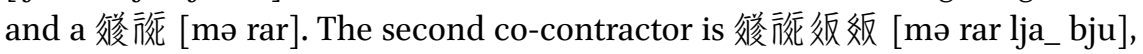
who could have been the son's brother, paternal uncle, or another member of

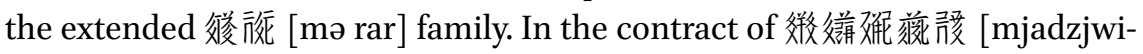
khjwi-wjazji], the first co-seller is referred to as "younger brother, 薇配 [śja

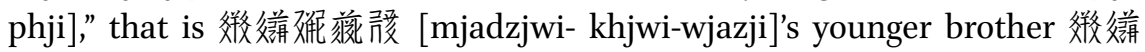
菠瞰 [mja dzjwi- śja phji]. Because a younge brother is supposed to share the same surname, only his given name appears on the contract. The second co-seller to this contract appears to be 㸺? [ljow ? ljow], whose relationship to the main party to contract is unclear. He certainly does not share the same family name, but could have been an in-law. Similar patterns are found in other contracts. 罯徽嫒 [khjiw bie_j ta]'s co-sellers are his two sons, the

158 TN: Gernet, Jacques. "La vente en Chine d'après les contrats de Touen-houang (IXe- $\mathrm{X}^{\mathrm{e}}$ siècles)" T'oung pao, 1957-01-o1, Vol. 45 (4/5), pp. 295-391. 
'black slave' and the 'red dog'; 㸷绞拼務 [ljow da kia ·jiw]'s co-contractors are

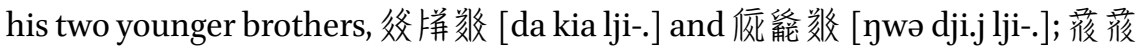

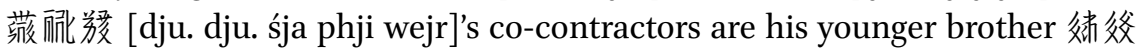

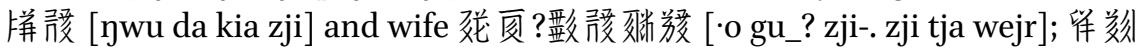

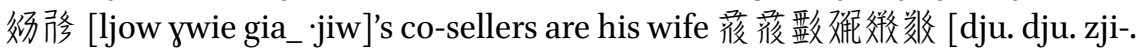
khjwi- mja lji-.] and their two sons, 影乘嗳 [zjo. dźjo wejr] "the long-living and

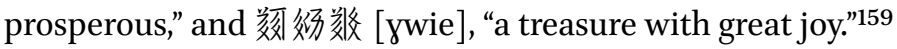

Witnesses are addressed as 㸝漖 [nwə dzjwo], "the ones who know," i.e. the witnesses. It is sometimes abbreviated as 版 [nwə] (to know, the knower). Usually, the main party to contract and the co-contractors are signed in parallel, whereas the the names of witnesses are a half or one space above, without indention. This is to show that the witnesses, as legal functionaries, do not share liability with the main signatories. There are between 2 and 4 witnesses. Sometimes, a man acts as a witness to multiple contracts signed around the

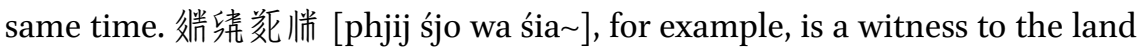

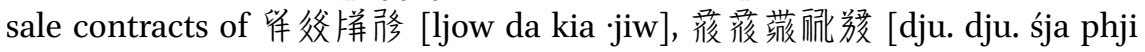

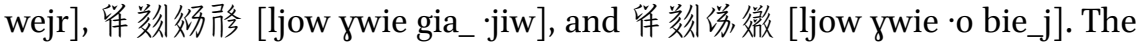
same man acts thrice as witness to land lease contracts. What is more, he also helped authenticate a grain loan account. ${ }^{160}$ It also happens that seller, a main party to one contract, serves as witness to other contracts. 㸺㳇拼務 [ljow da kia jiw], for instance, is a seller in his own contract, but a witness in that of

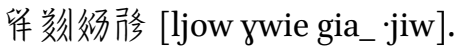

Signatures and stamps are conjoined and complementary. Stamping, either a print of the shape and length of the signatory's finger, or a symbolic icon that represents the signatory's legal persona, come after the signatures in the typical format of a contract. Stamping is an act of credit and commitment. Whether in sell and purchase, lease and loan contracts, stamping is necessary. In this case, the stamps are in the same order as the signatures: first the seller, then the co-contractors, followed by the witnesses. Since the 'signatures' are in fact written by a professional transcriber, these icons and symbols are the only way to authenticate the credibility of the parties to the contract.

As we have noted before, individual icons are considered to be more solemn than the print of finger segments. Given the significance of land sale contracts, the signatories are many and the stamps tend to be more formal. The signatories try their best to maintain consistency in their way of drawing their trade-

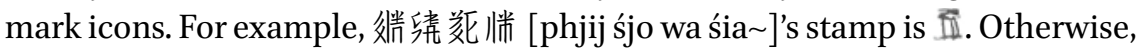

159 TN: the first character should be 㽬 [ edition of the book.

16o Shi Jinbo, 2005 (b), pp. 201-202. 
the signatories draw three segments of their fingers in four strokes. Sometimes, both icons and finger-segments are featured in the same contract. In the earliest land sale contract, dated to the Gengyin, 22nd year of Heavenly Prosperity, the seller and the co-sellers print their finger segments, whereas the witnesses drew their icons.

Over time, fewer sellers resorted to printing finger segments. In later contracts, only witnesses, and sometimes co-sellers, printed finger-segments. It seemed that there was an emerging consensus that the printed shapes of finger-segments were less reliable than iconic symbols. In most of these contracts, the principle seller draws his icon, whereas other parties, sometimes co-sellers included, printed their finger-segments. It is worth noting, for

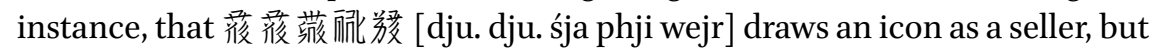
prints finger-segments as a witness in 篗爸胼骰 [ljow da kia ·jiw]'s contract.

In rare cases, some parties involved in the contract fail to produce any stamp. This duty might have eluded 倠?? [ljow?sa?], the last witness to 蕧後

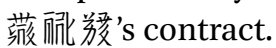

The Tanguts did use stamps in a more modern and literal sense, with the icons inscribed into a seal. Seal stamps are found in Инв. No. 2157-4 and Инв. No. 5522-3 accounts, amongst others. Seals are much more formal and reliable than the spontaneous artistic stimulus of the signatory. Only a consistent icon signals credibility.

A considerable number of Chinese social documents found in Khara-Khoto date to the Yuan Dynasty. Contracts in the Yuan era feature not only icons and finger-segments, but also black-ink stamps. During this period, both the "signature + icon" formula and increasingly formalised seal stamps were in use. Finger-segments in the Tangut era had by then all but disappeared. ${ }^{161}$

\subsubsection{White vs. Red Contracts}

The overarching policy on land sale in the Laws of Heavenly Prosperity is that of non-intervention: the imperial government recognises the validity of contracts made privately by consenting parties, so long as the flow of tax revenues remains uninterrupted. The contract dated to the 22nd year of Heavenly Prosperity, for example, states unequivocally that "taxes are paid," followed by what looks like the stamp of a tax-collector.

161 See Tala; Du, Jianlu; Gao Guoxiang (eds.). Zhongguo cang Heishuicheng Hanwen Wenxian [中國藏黑水城漢文文獻]: Han Chinese Documents in the Chinese Collection of Khara-Khoto Manuscripts, vol. 6. Beijing: National Library of China Press, 20o8, pp. 1237-1263. 
In the Chinese legal tradition, there is a distinction between the "red" and "white" contracts. White contracts are the more common contracts, not stamped by the red seal of the government. Red contracts, on the other hand, are recognised by the government. Such a distinction also exists in Western

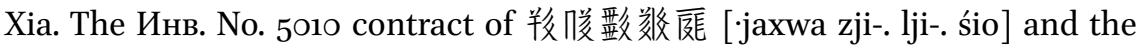

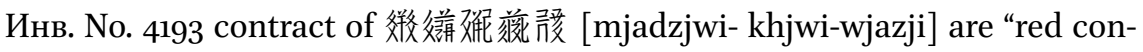
tracts" that feature red seals.

The seals that produce these red stamps are not local govenrments, but the local offices of the Department of Transaction Taxes. These are large, usually $23.2 \times 7.3 \mathrm{~cm}$ rectangular seals, with lotus flowers and leaves below and above. When stamped on a regular piece of paper, the seal almost takes up the entire width. The red stamp reads, from right to left, 校叛数㥢 [phə źji. zji.j io.], "Department of Transaction (Sell and Purchase) Taxes." Further down, there are four vertical lines of characters. The first three are in small font and barely legible. In the fourth line, three characters are large enough for us to

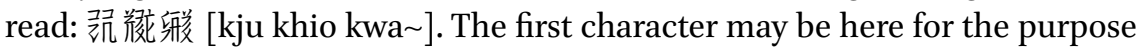
of phonetic notation. The second character means "well," "adept," or "artful." The third character means could also be a notation of some sort, but it also means "to fill" or "to water" in other contexts. The precise meaning of the three-character expression remains so far impenetrable. This line is followed by the iconic stamps, which are also found below the second line. With the red seal, the contract is certified by the government. It also proves beyond doubt that all taxes have been paid.

The seal of transaction taxes is used beyond the context of sell and purchase contracts, in a wide array of legal documents. Both the Инв. No. 6377-13 account of transaction taxes, and the Инв. No. 763 о-2 Livestock Sale Contract dated to the You year of Guangding, for example, feature the official seal of the Department of Transaction Taxes.

Generally, "white contracts" are technically illegal contracts, for they allow room for tax evasion. The question then is: are all the formal contracts prepared and kept by the Pudu Temple illegal, despite all the signatures, stamps, and other formalisms? It should be noted that these "white contracts" do specify that any breach of contract would be prosecuted by the laws of the empire, and that the penalised party has to pay gold to the government. Therefore, these are not informal agreements outside the orbit of the government. Quite the contrary, they invoke and invite heavy involvement by the government. Perhaps it is best to consider them as contracts established by customary laws, in coordination with the imperial laws.

The key practical purpose of red contracts is to ensure tax payment, and to stem out tax evasion. In later periods, to preempt any corruption on the part of 
government officials, tax laws require that the receipts be attached to the end of the contract. These are referred to as the "tails" of contracts. But this practice did not yet gain currency in the Tangut era.

3.1.7 Land Acquisition, Monopoly, and Aggravation of Wealth Inequality The imperial court of Western Xia placed an equal emphasis on farming and pasturing. Agricuture in fertile farmlands was essential to filling the granaries, providing for the armies, and ensuring stability for the empire. Although Khara-Khoto lies at the northwestern frontier, and suffers constant drought, the area boasts ample arable land nourished by the meltwater in the Qilian mountains. Therefore, Khara-Khoto claims both economic and strategic importance in the Tangut Empire.

Given the general shortage of arable land within its borders, the Tangut rulers were especially keen to maximise efficiency by sound management tactics. They borrowed heavily from Chinese land governance, but also built on them and developed a rigorous institution of land use and management. The Laws of Heavenly Prosperity requires that all peasant households register their land in details. ${ }^{162}$

Land was traded freely in Western Xia. Book 16 of the Laws of Heavenly Prosperity contains extensive rules and regulations on land transaction, but unfortunately this chapter is entirely lost. Therefore, we are deprived of the opportunity to see more details. But there are inklings of these laws in other chapters, such as the rules on measurement and registration in Book 15:

When the many undertake to transact land, let the name of the seller be cancelled out in the files. Let the buyer proclaim, "I wish to register the land under my name" to the Bureau of Transfer and Transportation. Let the buyer follow the laws on tax, labour, and hay levies. If the seller's name is cancelled, but the buyer does not register his name in a timely manner, then let the evasion of taxes in the interim time be tried as if in a case of theft. ${ }^{163}$

Poorer peasant households end up losing their means of subsistence after the sale. Even a seller who owns multiple patches of land is worse off after selling one of them. In most cases, peasants are left landless after selling their land for grains. They would have to rent a patch of land to farm from wealthy landlords. The long scroll of land sale and lease contracts shows that it is oftentimes the same buyer who loans out the land to a needy seller. For example, on the

162 Revised Laws of Heavenly Prosperity 15, p. 514.

163 Revised Laws of Heavenly Prosperity 15, p. 509. 


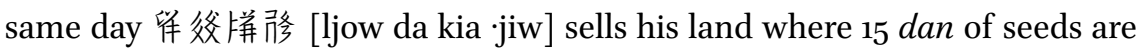
sowed, he rents a land slightly smaller, where 8 dan of seeds are sowed, from his buyer, the monks at the Pudu Temple. The leased land seems to have been

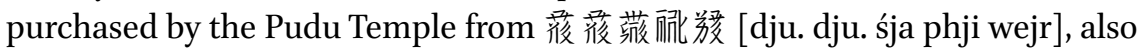

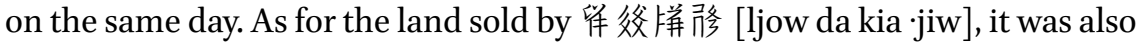
leased out on the same day.

The landless peasants, doubly exploited in the process of selling and renting, become tenant farmers. The price at which they sold their own land is forced down to the minimum, given their neediness and desperation. For the same neediness and desperation, the rent is pushed to the maximum by the landlords.

The long scroll of land sale and lease contracts shows that the Pudu Temple exploited the poverty of peasant families in the interim months between two harvests. The monks acquired land on a massive scale. The scroll that survives to the present day is a manuscript fragment, so we do not know how long the original contract scroll was. What we see could have been the tip of an iceberg. We also do not know how much more land the Pudu Temple might have acquired in times before or after the first year of Heavenly Celebration, whereto all our surviving contracts are dated. But one could imagine that these predatory economic activities could have been enduring legacy of the Pudu Temple. As early as in the Dunhuang contracts, we see that temples were buying land. In Khara-Khoto, both temples and landlords leveraged their resources to amass land and concentrate wealth, turning countless land-owning farmers into tenant peasants, and exacerbating preexisting inequalities. As the tenant peasants struggled to pay their rents and enter into a vicious cycle of impoverishment, their social status spirals down, further destabilising the base of the Tangut society. One practical consequence is on defence. The Dangxiang Tanguts provided the main force of the Tangut army. We know that despite all the impressive resistance that Western Xia put up against Mongol invaders, the performance of the military was suboptimal by earlier standards. In particular, Khara-Khoto was taken without fierce counterattacks. It seems that as the society and its economy further destabilised in the late Tangut period, the centripetal force of Tangut power weakened steadily and significantly. Therefore, the Tanguts could not have effectively defended a government whereto they no longer entrusted, and on which they could not depend.

\subsubsection{Features of Tangut Land Sale Contracts}

3.1.8.1 New Historical Sources for the History of Contracts

The discovery of Khara-Khoto land sale contracts adds new materials to the historical study of Tangut society and economy, in particular, but also to the historiography of contracts, in general. A comparative and connective survey 
of these 12 contracts opens up new ways to understand the idea and the use of contracts in historical contexts.

\subsubsection{Reflection on Land Transaction and Social Lives}

The contracts paint a picture of poverty and hardship in Khara-Khoto toward the end of the Tangut era. The peasants suffer a grave shortage of grains in the first two months of the year, and cannot maintain subsistence without selling their ancestral land. Their impoverishment feeds into the monopolistic and acquisitive ventures of large landlords and temples. Such phenomena usually occur in the declining years of Chinese dynasties. Western Xia is no exception.

\subsubsection{Insights on Land Conditions and Management}

The contracts shed new light on the conditions of government-owned or privately owned land, changing dynamics and states of peasant ownership of farmland, modes of land management, land transactions, land prices, and so forth. With a series of interrelated contracts, in particular, we are able to paint a picture of land locations, their directions to canals and water supplies, their neighbouring lands, size, and distribution.

\subsubsection{Characteristics of Local Settlements}

The contracts show that Khara-Khoto peasants built their abodes on their own land. The scattered pattern of residential quarters may be explained either by the pasturing tradition of the Dangxiang people, or in the light of local realities: sparse populations across spacious lands.

\subsubsection{Irrigation System}

Given the draught and the dearth of natural rain, the bloodline of Khara-Khoto farmlands relied on artificial irrigation through manmade canals, and the supply of the Black River. Extensive references to various canals in the land sale contracts confirms what we know from the Laws of Heavenly Prosperity, and greatly enriches and visualises our understanding of how water was used and managed in Khara-Khoto.

\subsubsection{Data on Tangut Land Prices}

For the first time, the contracts reveal en masse the prices of Tangut farmlands. The rigorous documentation of land taxes in the land sale contracts shows the level of importance the Tangut bureaucracy attaches to agriculture and the revenue it generates. Tax data in these contracts also verify the tax rate, clarify 
the complexities of tax payments in Western Xia, and fill in the details that are nowhere to be found in a law code such as the Laws of Heavenly Prosperity.

\subsubsection{Inter-Ethnic Influences on the Structure of Economic Sectors}

The contracts tell the story of the Dangxiang Tanguts whose ancestors acquired farming skills from Han Chinese peasants, and are now more land-based than pasture-roaming. Historically, inter-ethnic exchanges and contacts have shaped the economic lives of populations across spatial frontiers.

\subsubsection{Heritage and Innovation in Tangut Sell and Purchase Contracts}

Tangut land sale contracts inherit the basic legal format from the Chinese tradition. But on top of it, the Tanguts developed their own styles and formulas. The contract begins with the date but omits the reasons for the transaction. It severely penalises any breach of the contract, records the tax rate, demarcates the four borders of the land concerned, permits two forms of stamping (symbols and finger-segments), as well as both "red contracts" and "white contracts." Some of the formats and formalities can be seen as intermediate forms in transition from Tang and Song to Yuan-Dynasty styles of contracts.

\subsection{Livestock Sales}

More than 20 Khara-Khoto social documents are contracts of livestock sale. They make up a large proportion of the entire corpus of medieval livestock sale and loan contracts. Additional Tangut livestock sale contracts have been excavated in the Haimu Cave, in Wuwei, Gansu. These contracts are critically informative primary sources that shed light on livestock-raising and trading in Western Xia.

\subsubsection{Translations of Tangut Contracts of Livestock Sale}

Khara-Khoto livestock sale contracts are either individual, single-page contracts, or documents within a large scroll of papers, or still, recycled to bind Buddhist sutras. In the last case, the contracts are usually incomplete, left with only half of its original content, or with its upper and lower sections cut out and cast away. All these contracts are written in the Tangut cursive. Below, I present, in chronological order, the translations of 11 surviving Khara-Khoto livestock sale contracts, where key information and data, such as price, quantity, and types of commodities, remain legible and identifiable. They are followed by the two pieces of livestock sale contracts found in Wuwei. 


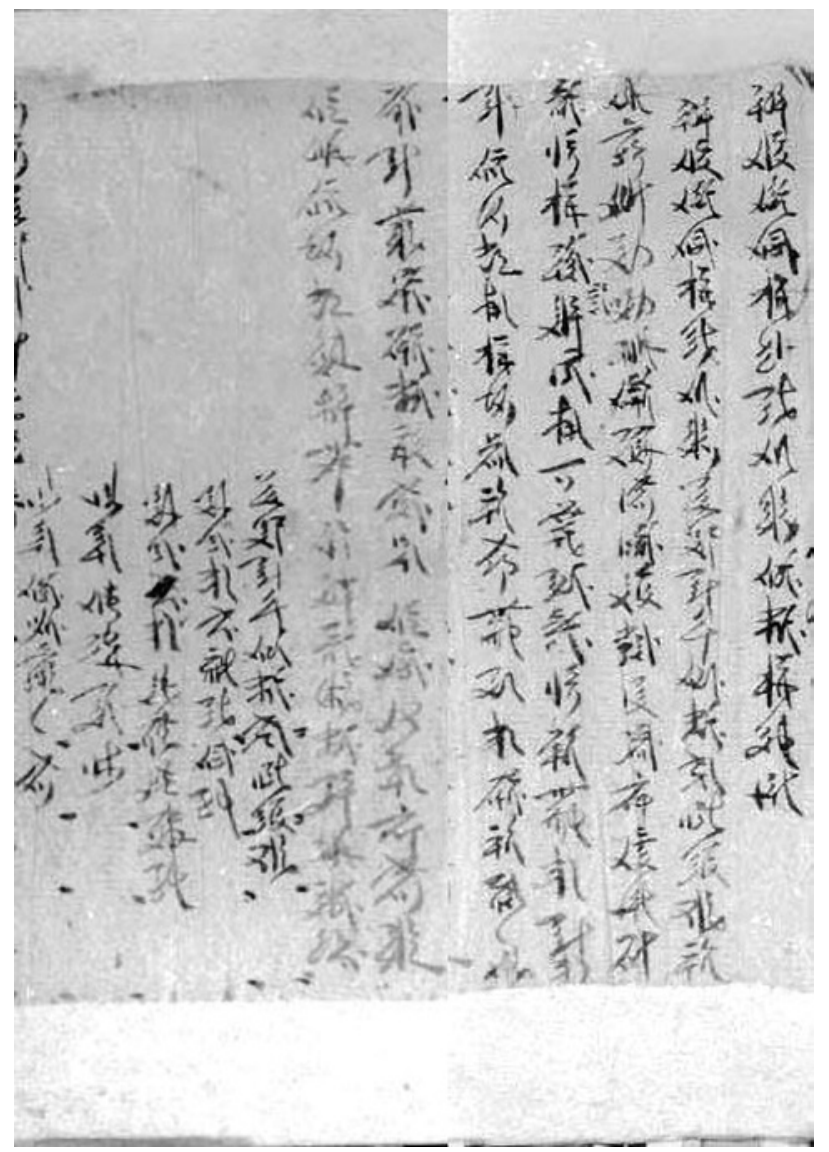

FIGURE 163 Инв. No. 5124-3(5, 6): Yin year of Tianqing (1194) contract of livestock sale

1. Инв. No. 5124-3 $(5,6)$ Contract of Livestock Sale in the Yin Year of Heavenly Celebration (1194), found in the long scroll of manuscript Инв. No. 5124-3. There are 12 lines of Tangut in the cursive. Perhaps due to errors in the first line, the second restarts the main text of the contract. The contract features signatures and stamps (all finger-segments) near the end. ${ }^{164}$

Translation:

On the 29th Day of 1st Month of the Yin Year, the contract party 诋䉼礏 澱訾数 [ywe ze zji-.ya. wa. lji-.]

164 Russian Collection of Khara-Khoto Manuscripts, vol. 14, pp. 16 and 17. 
Presently to the grain managers at the Pudu Temple 篻淩姘 [ljow lja mja], voluntarily sells his

Two full-teethed cattles, 1 full-teethed black ox et al., at the price of 5 dan of wheat and 2 dan of coarse grains, already paid. Neither the payment nor the livestocks are over-

due. Should any dispute arise either from the government or privately, let the penalty be 5 dan of wheat, according to the laws. Willing. Let the terms be enforced according to the contract.

Contract Party: 後䉼徦敛数 [ Đwe ze ya. wa. lji-.] (stamp)

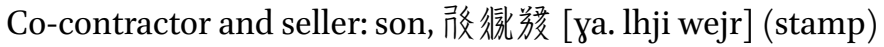

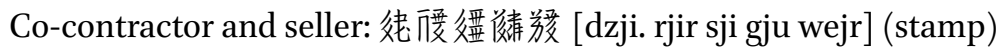

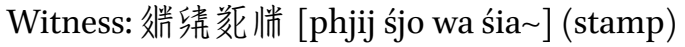

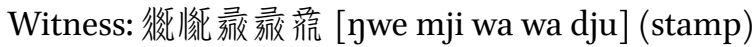

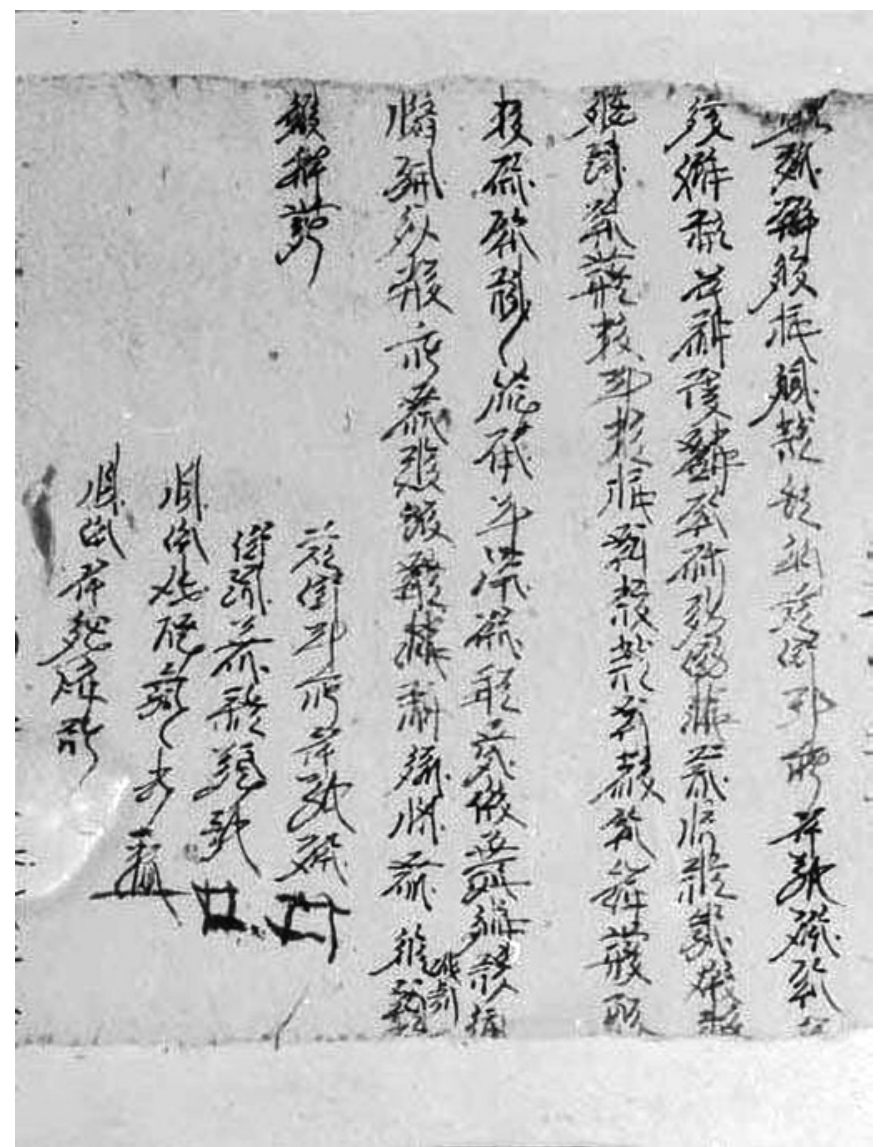

FIGURE 164

Инв. No. 5124-4(4): Yin year of Tianqing (1194) contract of livestock sale 
2. Инв. No. 5124-4(4): Contract of Livestock Sale in the Yin Year of Heavenly Celebration (1194), from the contract scroll Инв. No. 5124-4. There are 9 lines of Tangut in the cursive style, ending with signatures and stamps. ${ }^{165}$

Translation:

On the 3rd day of the 2nd month in the Yin Year of Heavenly Celebration, the contract party 篗㮔㖁 [ljow wejr khjwi-] et al., to 篗 [ljow]

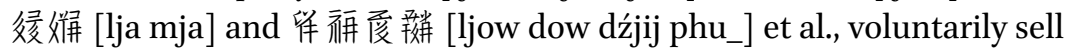
a full-teethed female camel and

A horse, at the price of 2 dan of wheat and 3 dan of coarse grains, already paid.

Neither the payment nor the livestocks are overdue. If third parties, such as members of the same chao,

initiate a dispute over the livestocks, let the guilty party be prosectued according to the Laws and Orders, and pay the penalty fee, according to the laws, of 3

dan of wheat. Willing.

Contract Party: 华涭㖁 [ljow wejr khjwi-] (stamp)

Co-contractor: son, 婹聠 [dźjwo wejr] ${ }^{166}$ (stamp)

Witness: 栧㣪暍最进 [dzji. rjir wa wa tsji-] (stamp)

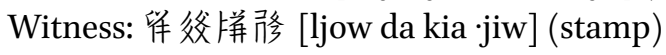

165 Russian Collection of Khara-Khoto Manuscripts, vol. 14, p. 20.

$166 \mathrm{TN}$ : I read the name as 橂盛. They appear as 打子 in the Chinese edition. 


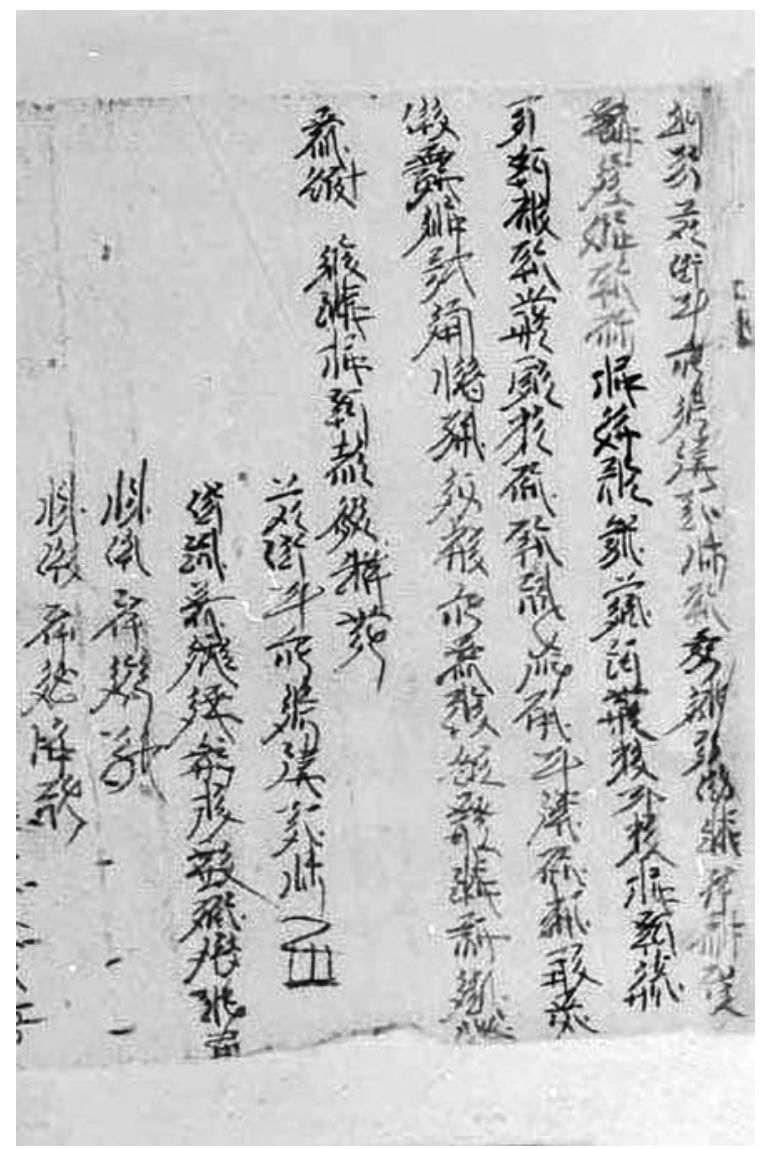

FIgURE 165 Инв. No. 5124-4(5): Yin year of Tianqing (1194) contract of livestock sale

3. Инв. No. 5124-4(5): Contract of Livestock Sale in the Yin Year of Heavenly Celebration (1194), from the long scroll Инв. No. 5124-4. There are 9 lines of Tangut in the cursive script. The contract ends with signatures and stamps. ${ }^{167}$ Translation:

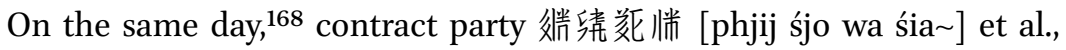
voluntarily to 徉祩爱彩 [ljow dow dźjij phu_]

㣭妙 [lja mja] et al., sell their own 2-teethed male camel, at the price of 2 dan of barley

167 Russian Collection of Khara-Khoto Manuscripts, vol. 14, p. 20.

168 The precise date is the third day of the second month in the Yin Year of Tianqing. 
and 1 dan of millet, already paid. Neither the payment nor the livestock is overdue. If third

Parties, such as members of the same chao, should initiate disputes, let the culpable party not only be prosecuted according to the Laws and Orders,

But also pay the government a penalty fee of 2 dan of coarse grains.

Contract party: 䍀绕获怑 [phjij śjo wa śia ] (stamp)

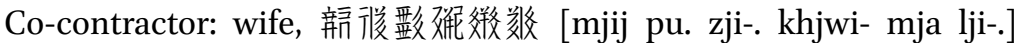
(stamp)

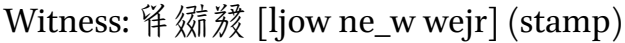

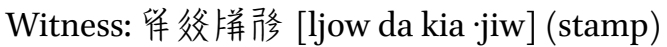

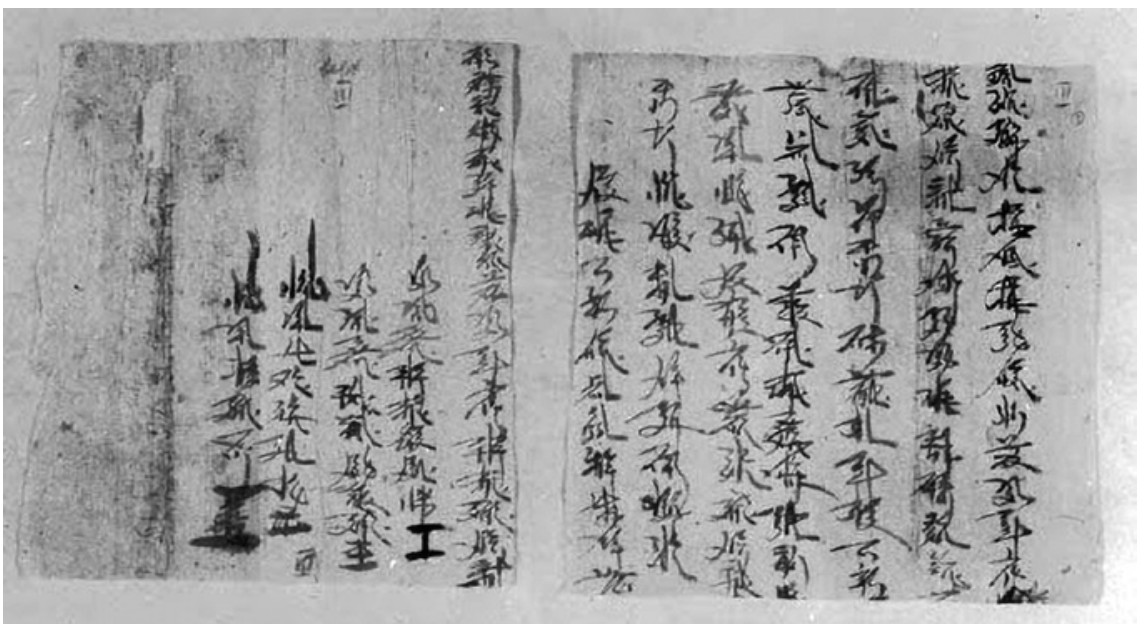

FIGURE 166 Инв. No. 2546-2, 3: Hai year of Tianqing (1203) contract of livestock sale

4. Инв. No. 2546-2, 3: Contract of Livestock Sale in the Hai Year of Heavenly Celebration (1203). The contract features 12 lines of cursive Tangut handwritten on a $19.6 \times 34.5 \mathrm{~cm}$ hemp paper. The materiality of the paper and the identity of the contracting parties seemt to suggest that the two papers belong in the same document. ${ }^{169}$

Translation:

On the 25th day of the 2nd month in the Hai Year of Heavenly Celebration, the contract party 争㐿 [tsow]

䉼烯很棓 [ze khjwi- tji-. gji] voluntarily sells his own three-teethed, short?

169 Russian Collection of Khara-Khoto Manuscripts, vol. 13, p. 84. 
red horse to 留而㭢 [ljow lhew gju_] at the price of 1 dan?

dou of coarse grains, hereby agreed upon. Should members of the same chao ever raise a dispute over the horse,

let 﨎很移 bear the responsibility,

not 元㛊. Let the party that reneges on its promise

be punished 1 dan 5 dou of coarse grains according to the laws. Own hearts willing.

Let the terms be enforced according to the contract and the actual circumstances.

Contract party: 拜䉼﨎很移 [tsow ze khjwi- tji-. gji] (stamp)

Co-contractor: 解䉼? [tsow ze lhji.j śia ] (stamp)

Co-contractor: ?版徦訯猴 [do ya. wa. khjwi-] $]^{170}$ (stamp)

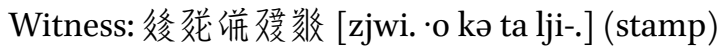

Witness: 唚碓茫 [pu. khjwi- dju] (stamp)

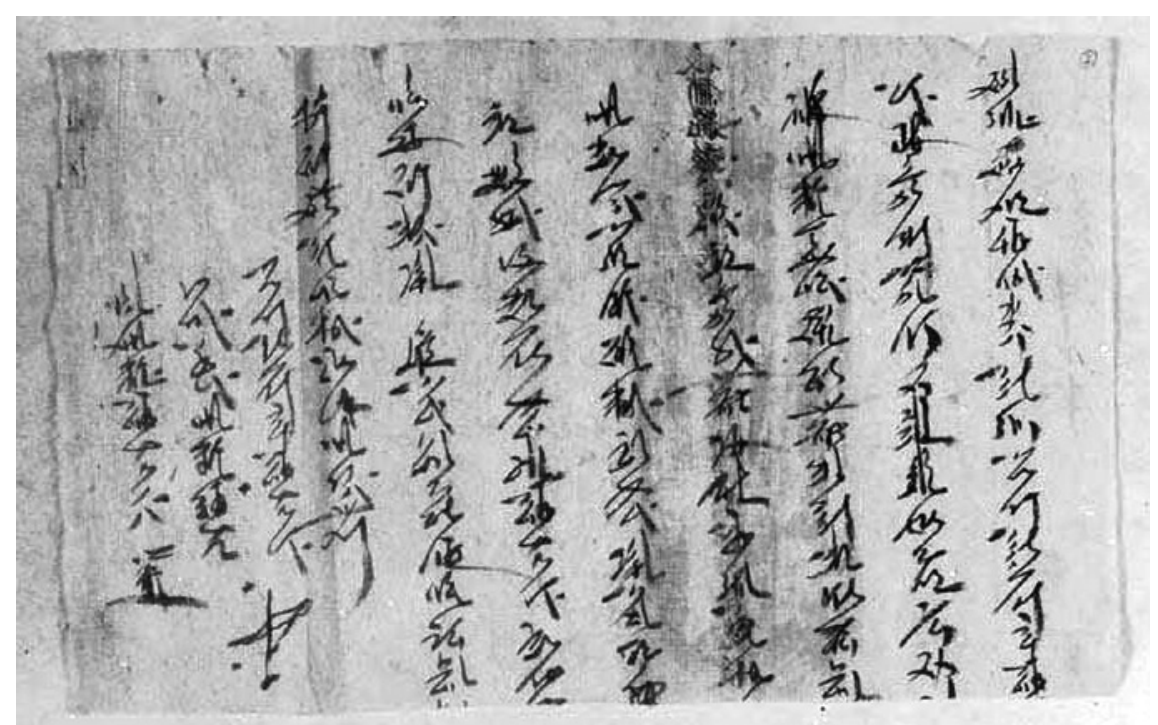

FIGURE 167 Инв. No. 2546-1: Hai year of Tianqing (1203) contract of livestock sale

5. Инв. No. 2546-1: Contract of Livestock Sale in the Hai Year of Heavenly Celebration (1203), is an individual contract, with 11 lines of cursive Tangut handwritten on a $20 \times 31.2 \mathrm{~cm}$ hemp paper. The contract begins with the year, and ends with signatures and stamps. ${ }^{171}$

170 TN: I am quite certain that at least the four characters listed here (difference, marriage, dog) all form a part of the name.

171 Russian Collection of Khara-Khoto Manuscripts, vol. 13, p. 84. 
Translation:

On the 3 oth day of the 2nd month in the Hai Year of Heavenly Celebration, contract party 留祩爱

䅭 [ljow dow dźjij wa] presently sells his own full-teethed femal camel? voluntarily

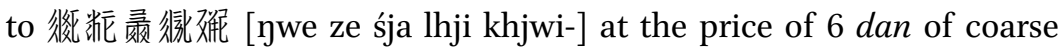
grains.

Now? that the livestock is <> purchased and transferred ? ? and ? ?

很䉼刻 [ywe ze wa], if other parties such as members of the same chao should ever raise

a dispute over the property right of the livestock, let 祩爱㴚 be liable. If any party regrets and reneges on the promise, let it be punished 5 dan of coarse grains according to the laws.

Let the above terms be enforced according to the contract and the actual circumstances.

Contract Party: 倠祩度瓶 [ljow dow dźjij wa] (stamp)

Co-contractor: 炛䉼? [ Đwe ze] (stamp)

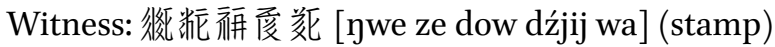

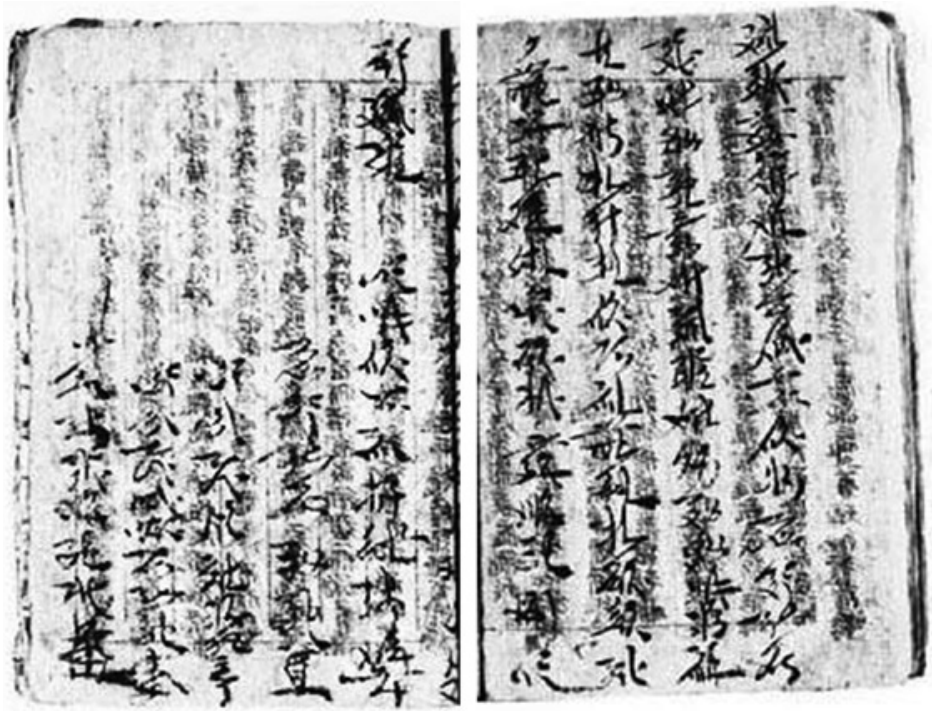

FIGURE 168 Инв. No. 5404-8, 9: Jiazi year of Tianqing (1204) contract of livestock sale 
6. Инв. No. 5404-8, 9: Contract of Livestock Sale in the Jiazi Year of Heavenly Celebration (1204), a handwritten manuscript on a $19.6 \times 27 \mathrm{~cm}$ hemp paper, found inside a Buddhist sutra of sewn binding. Some sutras are written on the back of used papers and sewn back into a text. Given available information on the main contract party, the font, character-spacing, line spacing, along with other clues from either content or format on the two pages of the paper, it seems that the 4 lines on the first page and 5 lines on the second page are the upper and lower sections of different contracts. The text on the first page begins with the date, month, and year: the $15^{\text {th }}$ day of the 11th month in the Jiazi Year of Heavenly Celebration (1204). On the second page there are signatures and the stamps. In fact, the first page and the second page of manuscript No. 5404-9 should have formed the same contract. There is a total of 10 lines of Tangut in the cursive script. The second page here should have been in the same document as the first page of manuscript No. 5404-9. The contract ends with signatures and stamps. ${ }^{172}$

Translation:

On the 15th day of the 11th month in the Jiaiz Year of Heavenly Celebration, the contracting party

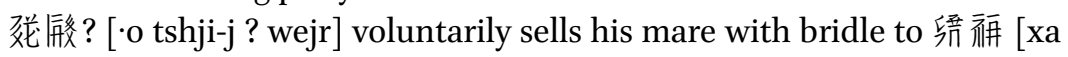
dow]

爱形 [dźjij tśhjwor], at the price of 5 dan of coarse grains, paid. There is no discrepancy in payment or livestock,

Thereafter, if members of the same chao either publicly or privately raise a dispute

$\cdots$

A reneging party is punished 5 dan of coarse grains according to the laws.

Own hearts willing.

Contract Party: ?弟 [wejr] (stamp)

Co-contractor: ...... (stamp)

Co-contractor: ....... (stamp)

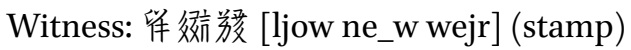

172 Russian Collection of Khara-Khoto Manuscripts, vol. 14, pp. 34-35. 

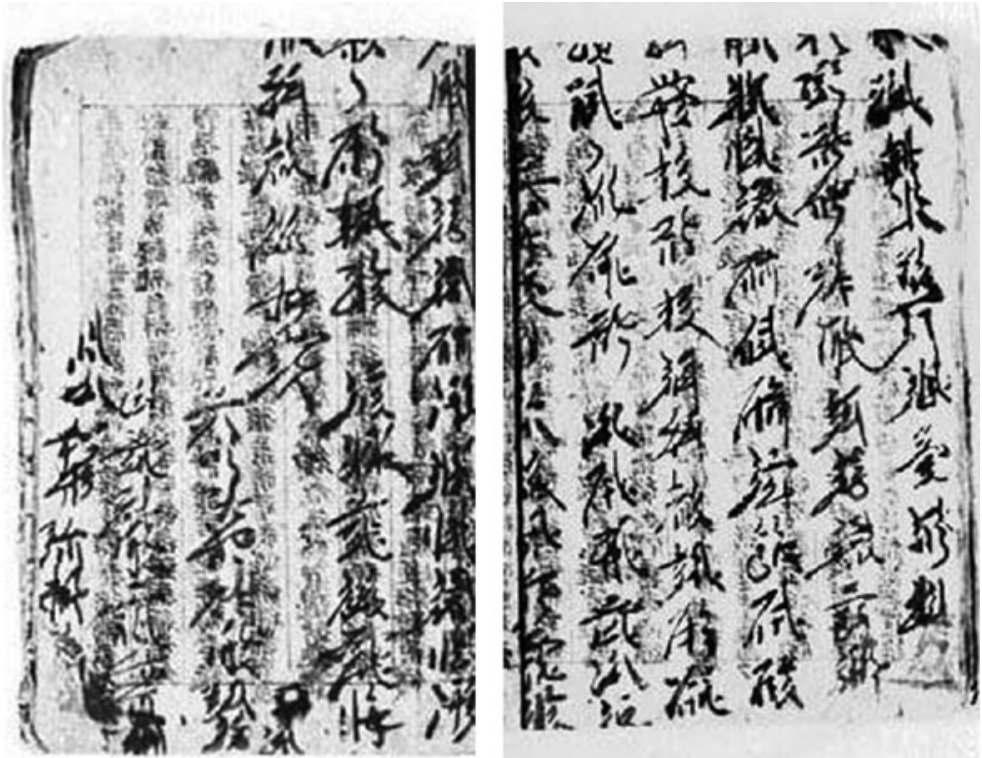

FIGURE 169

Инв. No. 5404-10, 5404-7: Zi year of Tianqing (1204) contract of livestock sale

7. Инв. No. 5404-10, 5404-7: Contract of Livestock Sale in the Zi Year of Heavenly Celebration (1204) is a contract reassembled from the right page of manuscript Инв. No. 5404-10 and the left page of manuscript Инв. No. 5404-7. There are 12 lines of Tangut in the cursive script, ending with signatures and stamps. ${ }^{173}$

Translation:

On the 16th day of the 11th month in the Zi Year of Heavenly Celebration,

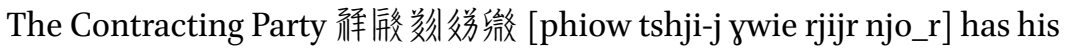
own

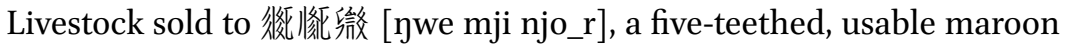
horse,

At the agreed price of 4 dan of coarse grains. Payment for the livestock Is not amiss. Over the horse, if any third party initiates

A dispute ... When? is overdue,

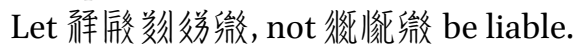

Let any reneging party, according to the laws on embezzlement, Pay a penalty fee of 5 dan of coarse grains. Own hearts willing.

173 Russian Collection of Khara-Khoto Manuscripts, vol. 14, pp. 34-35. 


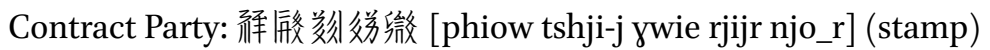

Co-contractor: ? 皮席 [yji-. njij] (stamp)

Witness: 餎娇邦 [bji gju_rjur] (stamp)

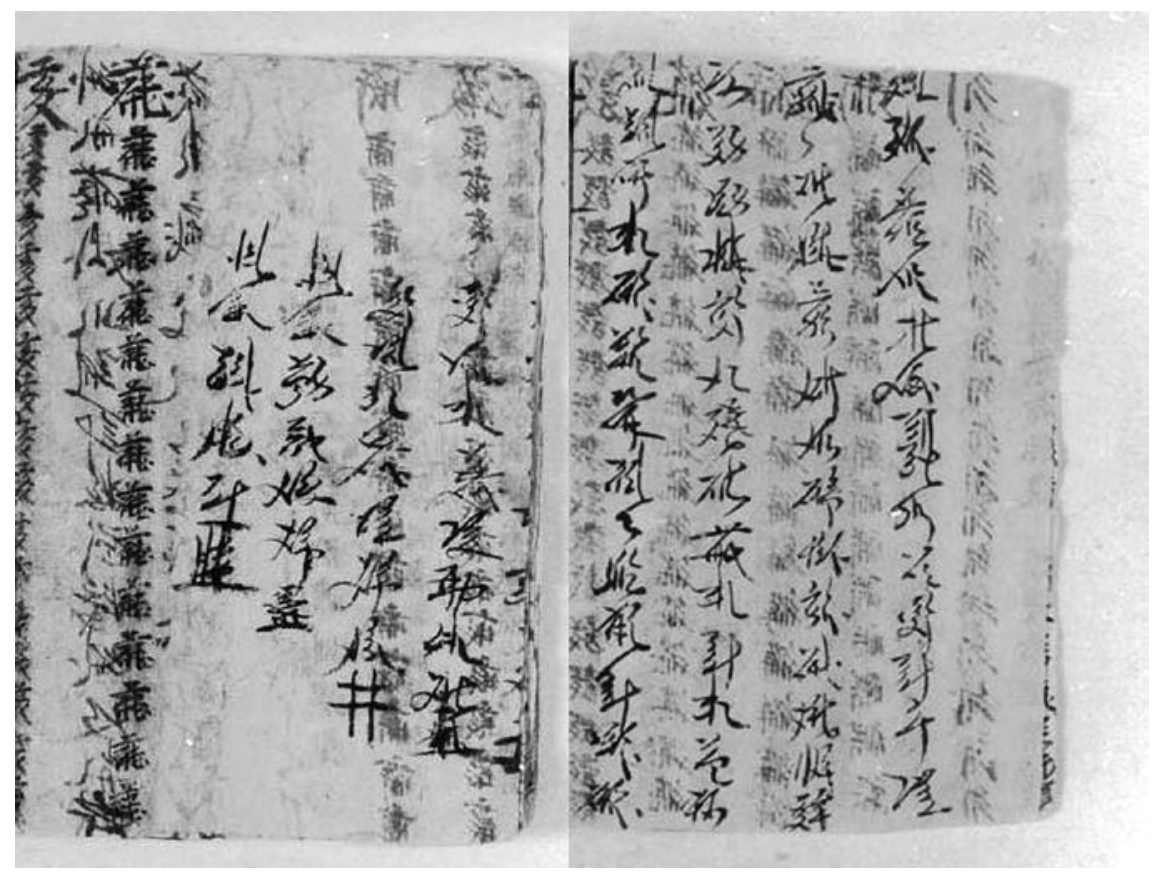

FIgURE 170 Инв. No. 2858-1: Chou year of Tianqing (1205) contract of livestock sale

8. Инв. No. 2858-1 Contract of Livestock Sale in the Chou Year of Heavenly Celebration (1205), is handwritten on a $19.8 \times 25.7$ hemp paper found in a sewn-bound Buddhist sutra. The 4 lines on the right are the livestock sale contract. There is another piece on the right page of the manuscript Инв. No. 285812. The 4 lines seem to be the second end section of a contract. The renaming first lines links it to the left of the contracting party's name in No. 2858-1. These two pieces are parts of the same contract. ${ }^{174}$

Translation:

On the 3oth day of the last month in the Chou Year of Heavenly Celebration, the Contracting Party 留 [xa]

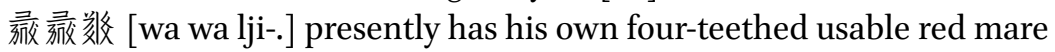
Voluntarily sold to 站该嫹 [thu tshja ta] for 7 dan

174 Russian Collection of Khara-Khoto Manuscripts, vol. 13, p. 119. 
Of coarse grains. The price is agreed upon and is not amiss. The livestock

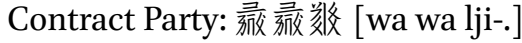

Co-contractor: 型娇徽 [xa gju_bie_j]

witness? 謊豗娇 [zji dźji_j gju_]

witness? 徬弱 [-ja ·jiw]

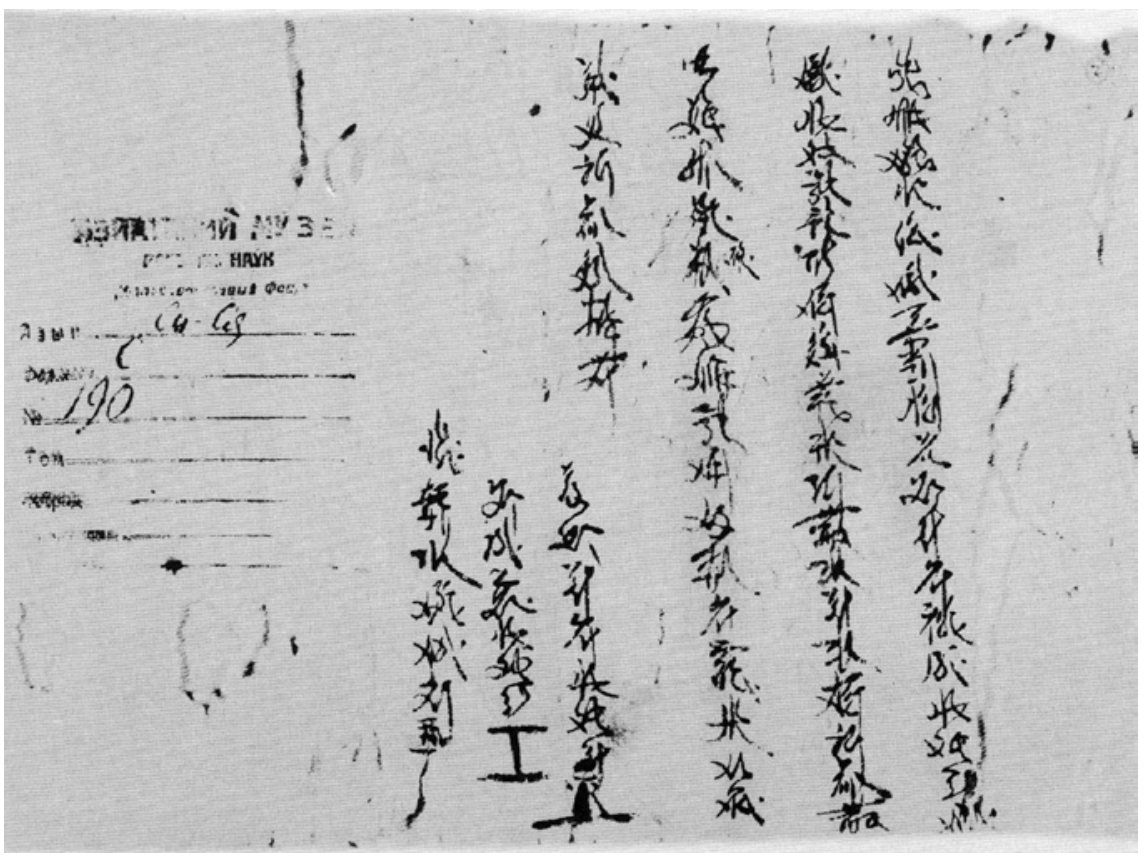

FIGURE 171 Инв. No. 7630-2: You year of Guangding (1213) contract of livestock sale

9. Инв. No. 7630-2: Contract of Livestock Sale in the You Year of Guangding (1213), is an individual contract with 7 lines of Tangut in the cursive script handwritten on a $19.7 \times 39.5 \mathrm{~cm}$ hemp paper. The contract begins with the date, ends with signatures and stamps, and features the red seal of the Department of Transaction Taxes. ${ }^{175}$

Translation:

On the 3oth day of the $5^{\text {th }}$ month in the You Year of Guangding, the con-

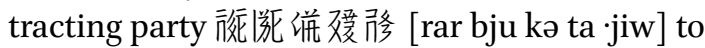

175 Russian Collection of Khara-Khoto Manuscripts, vol. 14, p. 187. 


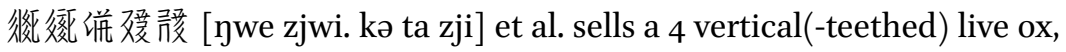
at the agreed-upon price of 4 dan of coarse grains.

Hereupon should any member of the same chao dispute the property ownership, let the seller assume responsibility.

And pay the penalty fee of 8 dan of coarse grains. Willing.

Contract Party: 垪㜴胗 [ko ta jiw] (stamp)

Co-contractor: 垪婹嗳 [kə ta zji $]^{176}$ (stamp)

Witness: 嚆㣪很很效 [mjij pu. tśjow lhji. gju_] (stamp)

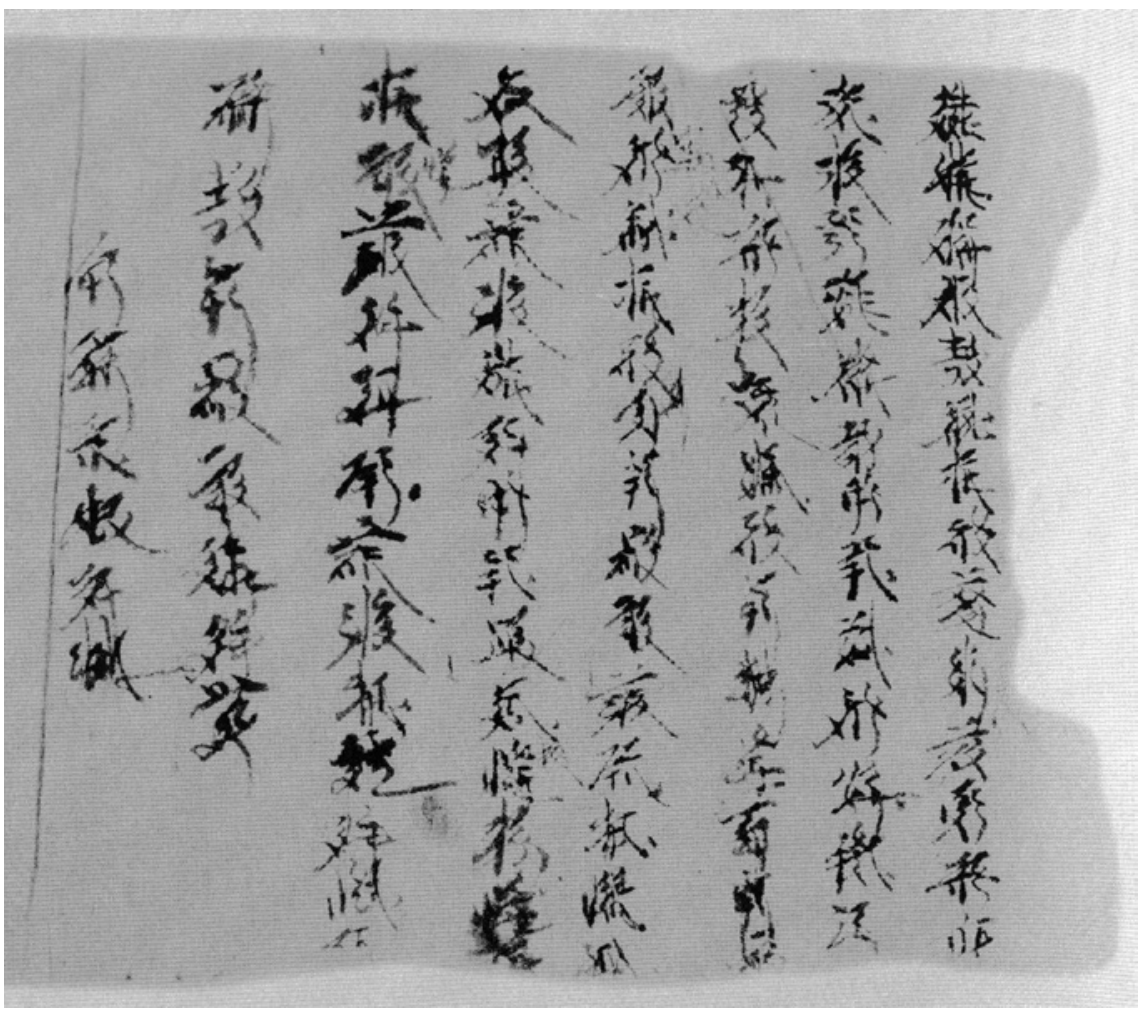

FIGURE 172 Инв. No. 7994-14: Hai year of Guangding (1215) contract of livestock sale

10. Инв. No. 7994-14: Contract of Livestock Sale in the Hai Year of Guangding (1215) is features 8 lines of cursive Tangut handwritten on a $17.7 \times 37.9 \mathrm{~cm}$ hemp paper. The text begins with the date, 27 th day of the 3 rd month, but it lacks signatures and stamps. There are also traces of erasures in the text. ${ }^{177}$

176 TN: This is another "little puppy," not the buyer referred to in the main text.

177 Russian Collection of Khara-Khoto Manuscripts, vol. 14, p. 243. 
Translation:

On the 27th day of the 3rd month in the Hai Year of Guangding, the Contract Party

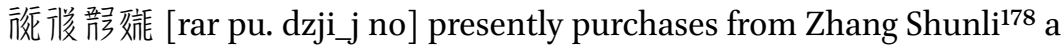
six-

Vertical(-teethed) ox, at the price of 10 dan, 1 dan of which has been paid. Another 8 dan has to be paid by the 2oth day of the 6 th month. If over the livestock there

Ever arises a dispute, let the aforementioned Shunli take responsibility. And let the penalty

Be double the sum of the price. Let any party that regrets over this arrangement pay the unregretting party 3 dan of coarse grains. Own hearts willing.

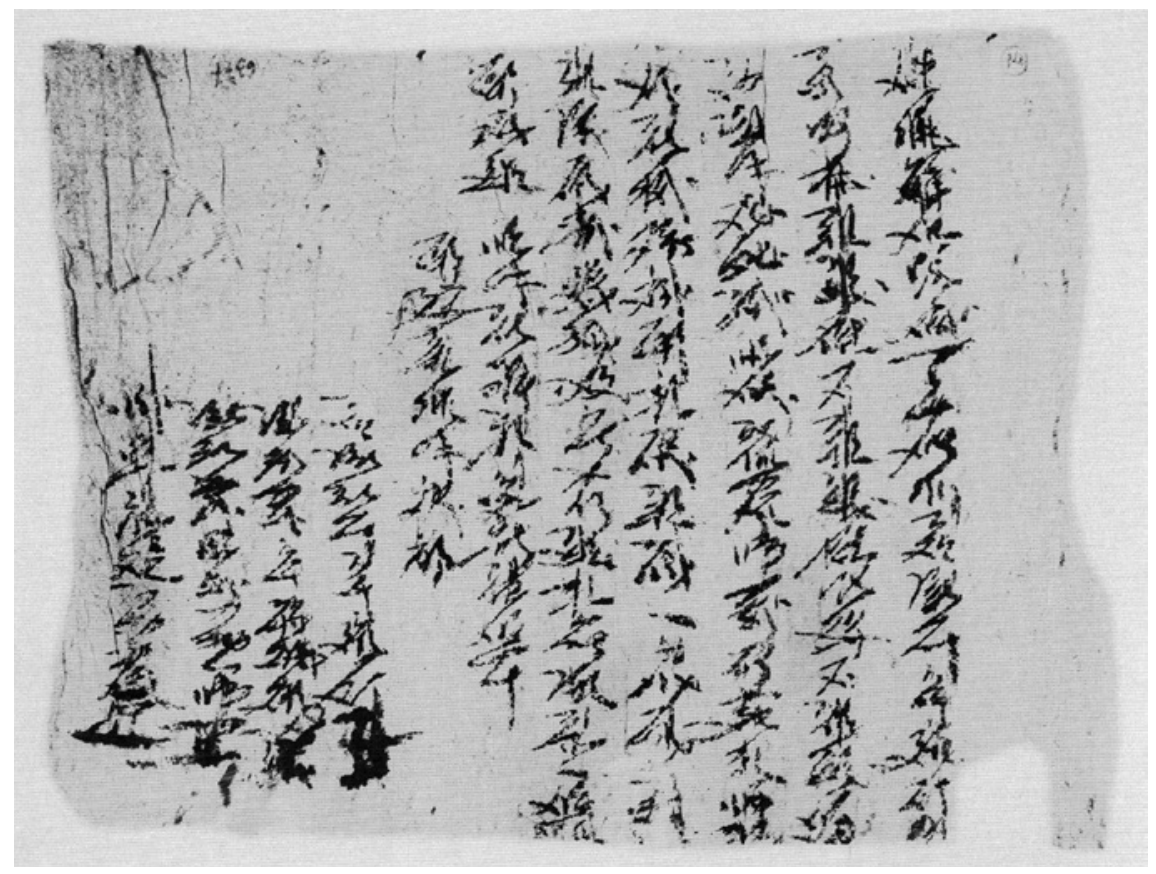

FIGURE 173 Инв. No. 6377-15: Zi year of Guangding (1216) contract of livestock sale

178 TN: The Tangut is 韧胗军 [tśjow śjwa kjiw]. 
11. Инв. No. 6377-15: Contract of Livestock Sale in the Zi year of Guangding (1216) is a single contract that consists of 11 lines of cursive Tangut handwritten on a $19.5 \times 21.1 \mathrm{~cm}$ hemp paper. The contract begins with the date: 16 th day of $5^{\text {th }}$ month in the Zi Year of Guangding, and ends with signatures and stamps. ${ }^{179}$

Translation:

On the 16th day of the 5th month in the Zi year of Guangding, the contracting party 留(?) ${ }^{180}$ [ljow khjwi- ywie]

Sells his own 2 vertical(-teethed), 6 female camels, 1 vertical(?), 1 maroon horse,

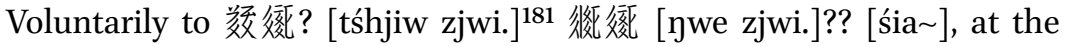
total value

Of go liang in silver, a price hereby agreed upon. Neither the livestock nor the payment is amiss.

Should any dispute over the horses, let the seller be responsible. If?

Regrets and reneges on the promise, let the party pay a penalty fee of 10 guan of cash, according to the laws. Own hearts willing.

Let the terms be enforced according to the contract and the circumstances.

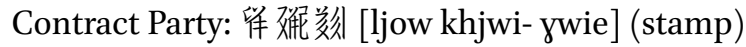

Co-contractor: 蟮?? 㖁 [ljow ?? khjwi-] (stamp)

Co-contractor: ?? 录录挜 [?? wa wa śia ] (stamp)

Witness: 俢绯?182 [.jiw dji.j ?] (stamp)

179 Russian Collection of Khara-Khoto Manuscripts, vol. 14, p. 145.

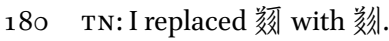

181 TN: I do not think the 确 [bju] is part of the name, as suggested in the Chinese edition. It's a preposition that goes with the verb of "selling volutnarily to" or "let someone have"

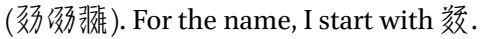

182 TN: The 緂 seems to be a typo in the Chinese edition. 


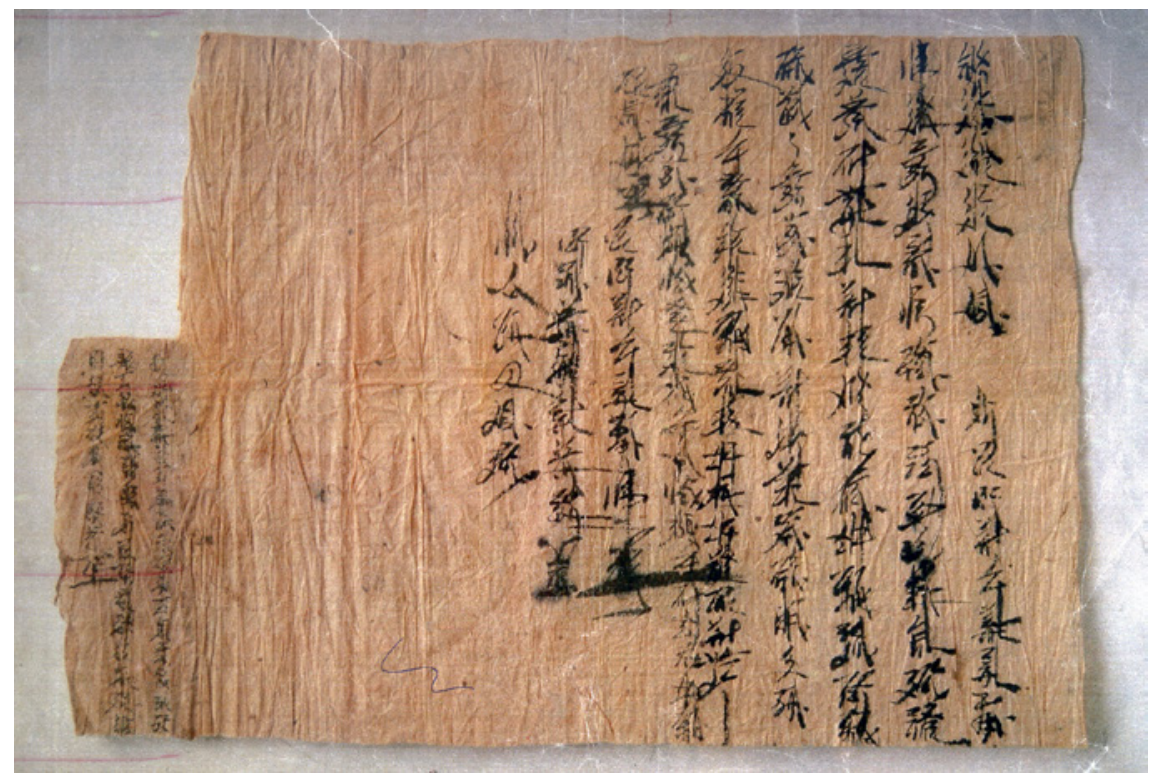

FIGURE 174 Wuwei G31.003[6727]1-2: You year of Qianding (1225) contract of cattle sale

12. Haimu Cave, Wuwei G31.003[6727]1-2 (1225): Contract of Cattle Sale in the You year of Qianding, now curated in the Wuwei Museum. The contract consists of 9 lines in cursive Tangut handwritten on a $30 \times 44 \mathrm{~cm}$ hemp paper. The text begins with the month and year, 9th month in the You Year of Qianding (1225). There is a small piece of paper attached to its lower left corner, where there are 3 lines of Tangut cursive writings, most of which are not legible. ${ }^{183}$

Translation:

On the ?day of the gth month in the You Year of Qianding, Contract Party: 龍影乘

怑 [dzow zjo. dźjo śia ], presently out of his own will sells a full-teethed black ox to [bji_j khjwi-]

[pa rja śjow] at the price of 65 guan in cash, hereby agreed upon. Neither the payment

Nor the livestock is amiss. If over the livestock a dispute ever arises,

Let the penalty be double the sum of the price. Willing.

If an individual is dishonest, let the reneging party pay 30 guan of cash to the unregretting party.

Contract Party: 釤乘㴹 [zjo. dźjo śia ] (stamp)

183 Chinese Collection of Tangut Manuscripts, vol. 16, pp. 387-388. 
Co-Contractor: 瓶靱 (Wu Mao) [gu_phu_] (stamp)

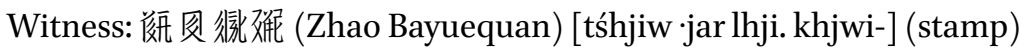

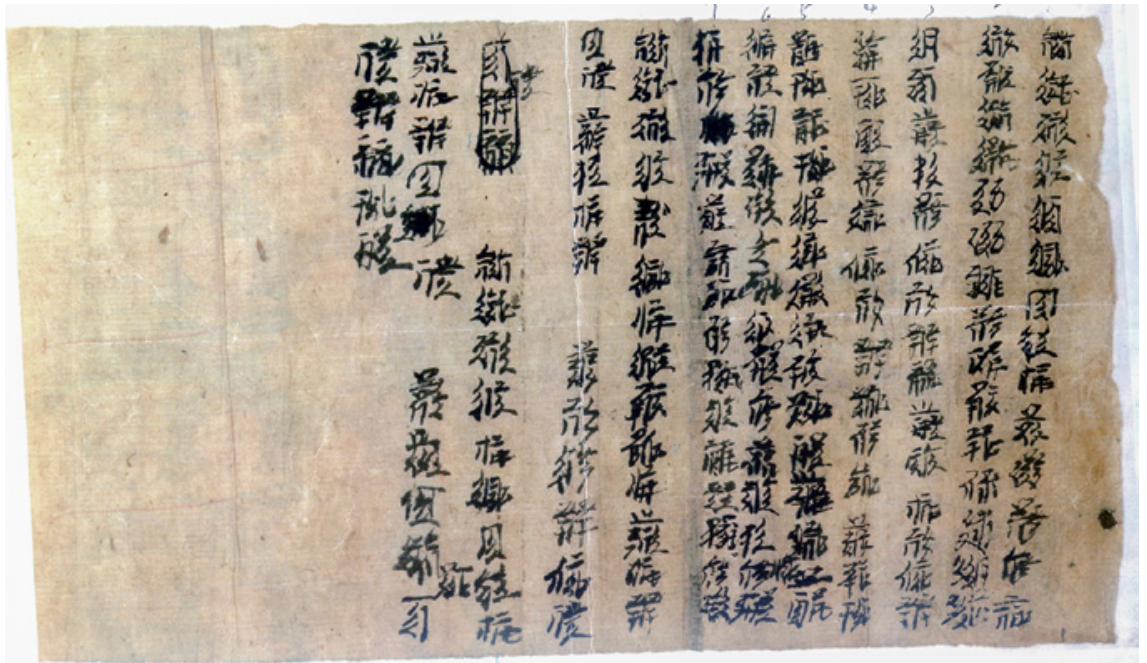

FIGURE 175 Wuwei G31·002[6726]: Xu year of Qianding (1226) contract of donkey sale

13. Haimu Cave, Wuwei G31•002[6726]: Contract of Donkey Sale in the Xu Year of Qianding (1226) consists of 12 lines of Tangut in the cursive script handwritten on a $17 \times 55 \mathrm{~cm}$ paper. The contract has not properly ended, and lacks both signatures and stamps. Furthermore, there are miscellaneous characters on the page that do not belong to the contract. They could be scribblings on the scrap paper by someone practicing handwriting. ${ }^{184}$

Translation:

On the 8th day of the 4th month in Xu Year of Qianding, contracting party 产 [śjwo]

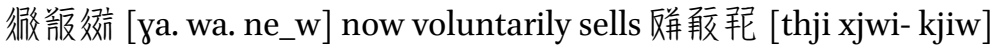

A yellow donkey for 50 guan in cash, of which 25 is paid

Immediately. The price of 5 o guan is negotiated and agreed upon. If any party is deceitful

Such as transferring the commodity as a loan privately or publicly, or if members of the same chao

Dispute the ownership of the property, let the seller be fully responsible, Not the buyer. Let a party that regrets and reneges on the promise ...

184 Chinese Collection of Tangut Manuscripts, vol. 16, p. 386. 
In addition, the Инв. No. 5404-9, 5404-8 manuscript is a Contract of Livestock Sale on the 25th day in the 1oth month of the Wei Year of Tianqing (1199). It is reassembled from the right section of Инв. No. 5404-9 and the left section of 5404-8. The 9 lines of Tangut are handwritten in the cursive style on hemp paper. The text begins with the date and ends with signatures and stamps. The extraordinary cursiveness of the handwriting, exacerbated by the fact that it has a Buddhist sutra written on the back, and by extra ink and soaking, leaves the text less than legible for our purposes. ${ }^{185}$

\subsubsection{The Format and Content of Livestock Sale Contracts}

Livestock sale contracts follow the general format of most Tangut contracts. Each contract begins with the date, and proceeds to state the name of the main contracting party, the type, quantity, and price of the livestock sold, as well as penalties against any breach of contract. The document ends with signatures and stamps of the contracting and co-contracting parties, as well as the witnesses.

\subsubsection{Time, Contract Party, and Buyer}

The earliest of the 11 Khara-Khoto livestock sale contracts is dated to the 29th day of 1st month in the Yin Year of Tianqing (1194). The latest is signed on the 16th day of the 5 th month in the Zi year of Guangding. The entire range falls within the late Tangut period. The selling takes place mostly in the winter months, from the last month of the previous year to the third month of the new year. But unlike grain loan accounts and land sale contracts, livestock contracts are not exclusively concentrated in these months. There are, for instance, 2 livestock contracts in the fifth month and 2 in the eleventh. Dates are customarily simplified in long scrolls. Here, by "Yin Year" is meant the Jiayin Year of the Tianqing era (1194). As in grain loan accounts, livestock sale contracts may indicate "on the same day" to refer to the precise dates in preceding documents. The two livestock sale contracts from Wuwei are dated to the You and the Xu Years of Qianding, only a year or two before the fall of the empire.

Тhe Инв. No. 7994-14 document stands out amongst all livstock sale contracts, for the main contracting party is not the seller, but the buyer. It is all the more a source of regret that the end of the contract is missing. So, we do not know what the signatures might have looked like. But in this case, the buyer initiates the contract.

Amongst all the names featured in the 13 contracts, there is some ethnic diversity in both the buyers and the sellers. Most are Dangxiang Tanguts. Some names, such as $\mathrm{Lu}, \mathrm{Hao}$, and Tu, seem to be of Chinese origins. As usual, we

185 Russian Collection of Khara-Khoto Manuscripts, vol. 14, pp. 34-35. 
cannot say with full confidence if the Liangs fall into the Fan or Han camps. It could be one way or the other.

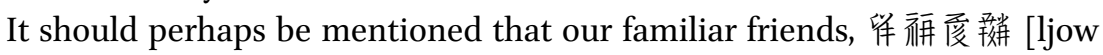
dow dźjij phu_] and 㲎㣭姘 [ljow lja mja], who act as 'grain agents' on behalf of the Pudu Temple in land sale contracts, appear in contracts of livestock sale as authorised managers of livestock for the same temple. As agents, or asset managers, these two fellows acquire properties and then lease them out to make profit for the monastic establishment.

\subsubsection{Reasons for Selling Large Livestocks}

In medieval Western Xia, livestocks are both means of consumption and means of production. Large livestocks are employed to tilt the land, bear burdens, and to carry soldiers and provisions in land warfare across large swaps of complex landscapes. Although Western Xia was renowned for its livestocks as a Tangu specialty, the empire forbids arbitrary slaughter of large livestocks, given their important status in the economy and the military. In fact, the Tangut government applies stringent rules and regulations on the slaughtering of large livestocks. The Laws of Heavenly Prosperity states that,

The many who slaughter their own cattles, camels, and horses, let each be tried and sentenced to four years of imprisonment for each animal killed, regardless of size. Let the sentence be five years for two animals killed. Let the sentence be six years for killing three or more large livestocks. ${ }^{186}$

Tangut farmers and herdsmen raised livestock primarily for domestic use. But surplus animals were also sold for cash and grains. Therefore, there is a subtle difference between the socioeconomic reasons underlying land and livestock sales. Most peasants sell the land on which their livelihood depends only as a last resort, when they are hard pressed by dire necessities of subsistence. In contrast, motivations for selling livestocks are more complex. There are two main reasons. A family sells its livestocks either out of poverty, especially in the inter-harvest months of the early spring, or to expand its income when there are extra animals on the farm, especially during and after their breeding seasons. Both motives are present in the livestock sale contracts studied in this chapter.

In the cases of Инв. No. 5404-8, 9 and Инв. No. 5404-10, mares and horses are sold in the 11th month of the year, a short while after the autumn harvest. The sellers could not have been out of grains so quickly. And although the Инв.

186 Revised Laws of Heavenly Prosperity 2, "On Stealing and Killing Cattles, Camels, and Horses," p. 154. 
No. $6377^{-15}$ contract was signed in the $5^{\text {th }}$ month, it does not seem that someone who could afford to sell 9 horses and camels for as much as go liang of silver-and not in grains - is doing it for subsistence. Chances are, in all these three cases, the sellers are selling surplus livestocks for extra income.

Of course, it is undeniable that most other livestock sales take place during the hard-pressing, inter-harvest months of the late winters and early springs. Such is the case in the three contracts found in the Инв. No. 5124 manuscript, and the two contracts found in the Инв. No. 2546 manuscript, the Инв. No. 2858 and the Инв. No. 7994 livestock sale contracts. In particular, the three contracts in the Инв. No. 5124 manuscript testify to the acquisitive and exploitative ventures of the Pudu Temple. They show that the asset managers of the monastery purchased large livestocks and leased then immediately leased them out to peasants deprived of their means of production.

\subsubsection{Types and Quantities of Livestocks Sold}

The animals sold in the 13 surviving livestock sale contracts are camels, horses, and cattles. The Laws of Heavenly Prosperity categories Tangut livestocks into four major categories: camels, horses, cattles, and sheep. ${ }^{187}$ What we see in the contracts are the first three, but not sheep. Perhaps the sheep are small enough to be traded without a formal contract.

Western Xia boasts a highly advanced pasturing industry. It is, after all, the ancestral legacy and traditional industry of the Dangxiang Tanguts. It is worth pointing out that, located in northwestern Western Xia, Khara-Khoto was a highly developed centre of the Tangut camel industry. Even to the present day, the area is known for its famed camels. By normal standards, Khara-Khoto shows all the undesirable natural conditions: sandy winds, scarce water, and freezing winters. However, the camels are uniquely suited withstand strong winds, sandy deserts, extraordinary temperature differences, and constant lack of water. Camels survived, reproduced, and prospered in the Khara-Khoto area. They were not only superb burden animals and excellent mounts, but also capable of tilling the soil, dragging carts and carriages, as well as moving mills and lifting up water. Needless to say, alas, camel fur and meat are of tremendous economic value.

But the Tangut livestock sale contracts document not only the species of the animal but their particular features, whether it is a full-teethed female camel, a two-teethed male camel, a camel usable for three years, a red mare, a five-teethed, usable maroon horse, six-vertical(-teethed) ox, etc. The number of teeth is used as a proxy for the approximate age of the animal concerned. It is equivalent to the notion of Suikou in the livestock industry of the Central

187 Revised Laws of Heavenly Prosperity 19, p. 599. 
Plains. ${ }^{188}$ It is also important to know the number of teeth to assess the animal's chewing and labouring ability. All things considered, the number of teeth is a simple way to represent the quality of the animal. An average Tangut would have known, for example, that a foal begins to shed its desiduous teeth and to grow a permanent set after two and a half years. By the age of five, the permanent incisors, pre-molars and molars should be in place. By this time, a male horse's canine teeth should also have emerged. ${ }^{189}$ To inspect a horse, one usually takes a glimpse at the lower incisors. An animal is 'two-teethed' if it grows the two lower incisors. It is 'four-teethed' if it has the pre-molars, as well. Once all the lower molars are properly in place, the horse is said to be "full-teethed" (qikou). ${ }^{190}$ The cattles do not have upper incisors, but four pairs of lower incisors. The middle pair is called the 'pincer teeth.' Permanent 'pincer' incisors are grown between 1.5 and 2 years of age. The next pair is the inner intermediate teeth. The permanent inner intermediate teeth are grown between years $2-2.5$. The neighbouring set of teeth is the outer intermediate teeth, which are grown when the calve reaches $3^{-3.5}$ years old. The outermost pair of teeth are the molars, which emerge in years $4-4.5$. The bovines are tically five years old when their molars reach up to the incisors. This is the prime age of the cattle.

Pasturing is the forte of the Tanguts. For the same reason, the Tanguts used an elaborate language to describe and differentiate livestocks. Some terms and expressions may have regional, local, or ethnic origins and characteristics, which are obstacles to identification and translation. The meanings and applications of some of them remain obscure. But with other basic terms, scholars are more confident. For example, the Tanguts signal the age of the livestock by the state of their teeth. As for the term "vertical," it is possible that the verb of vertical existence here refers to the existence of teeth grown in a vertical direction. This term is used to describe the teeth of the cattle that have grown two, four, or six vertical teeth. Whether these correspond to the 'pincer,' 'middle' and 'molar' teeth of the lower incisors remains a question to be asked in future research. As for "usable for three years" camels and "usable, five-teethed maroon" horses, the descriptions there seem to underscore the features, values, and practical utilities of the animals. Some contracts indicate the colours of the livestocks to avoid confusions.

There is an additional livestock sale contract fragment, in the manuscript Инв. No. 840-3, a layering paper in a Buddhist sutra. There are two paper fragments, and the livestock sale contract is found in the upper section. There is

\footnotetext{
188 TN: Chinese: 歲 $\square$.

189 TN: Although minimally trained in equine studies, I suspect that not all mares lack canine teeth.

190 TN: Chinese: 齊 $\square$.
} 
a diverse range of livestocks recorded in the text, from sheep and donkeys to horses, cattles, and camels. The total price is 98 dan 6 dou 5 sheng of coarse grains. Regrettably, both the beginning and end of the document are lost, so we literally couldn't make heads or tails of the larger context in which it was drafted. ${ }^{191}$

\subsubsection{Livestock Prices}

Price is the key data point in any livestock sale contract. In 10 of the 11 surviving contracts, the method of payment is grain. Only in one large-volume transaction, the payment is made in cash. In grain payments, the buyer may pay a mixture of fine and coarse grains. For the sake of convenience and consistency, I have converted all grain payments to coarse grains, based on rates derived from other Khara-Khoto documents studied in this book. ${ }^{192}$ The following is a chart that presents the data extracted from the livestock sale contracts, in chronological order.

CHART 15 Data in Khara-Khoto livestock sale contracts

\begin{tabular}{|c|c|c|c|c|}
\hline Register & Date & Livestock & Price & $\begin{array}{l}\text { Price in } \\
\text { coarse grains }\end{array}$ \\
\hline $\begin{array}{l}\text { Инв. No. } 5^{124-3} \\
(5,6)\end{array}$ & $\begin{array}{l}\text { Yin Year of } \\
\text { Tianqing (1194) } \\
\text { 29th Day of } \\
\text { 1st Month }\end{array}$ & $\begin{array}{l}2 \text { live, usable, } \\
\text { full-teethed, red } \\
\text { cattle, } 1 \text { full- } \\
\text { teethed black } \\
\text { cattle }\end{array}$ & $\begin{array}{l}5 \text { dan of } \\
\text { wheat, } 2 \text { dan } \\
\text { of coarse } \\
\text { grains }\end{array}$ & $\begin{array}{l}\approx 8.6 \text { dan of } \\
\text { coarse grains }\end{array}$ \\
\hline $\begin{array}{l}\text { Инв. No. 5124-4 } \\
\text { (4) }\end{array}$ & $\begin{array}{l}\text { Yin Year of } \\
\text { Tianqing (1194) } \\
\text { 3rd Day of the } \\
\text { 2nd Month }\end{array}$ & $\begin{array}{l}\text { Full-teethed } \\
\text { female camel, } \\
1 \text { horse }\end{array}$ & $\begin{array}{l}2 \text { dan of } \\
\text { wheat, } 3 \text { dan } \\
\text { of coarse } \\
\text { grains }\end{array}$ & $\begin{array}{l}\approx 5.7 \text { dan of } \\
\text { coarse grains }\end{array}$ \\
\hline $\begin{array}{l}\text { Инв. No. } 5^{124-4} \\
\text { (5) }\end{array}$ & $\begin{array}{l}\text { Yin Year of } \\
\text { Tianqing (1194) } \\
\text { 3rd Day of the } \\
\text { 2nd Month }\end{array}$ & $\begin{array}{l}1 \text { two-teethed } \\
\text { male camel }\end{array}$ & $\begin{array}{l}2 \text { dan of } \\
\text { wheat, } 1 \text { dan } \\
\text { of millet }\end{array}$ & $\begin{array}{l}3 \text { dan of } \\
\text { coarse grains }\end{array}$ \\
\hline Инв. No. 2546-2, 3 & $\begin{array}{l}\text { Hai Year of } \\
\text { Tianqing (1203) } \\
\text { 25th Day of the } \\
\text { 2nd Month }\end{array}$ & $\begin{array}{l}1 \text { three-teethed } \\
\text { red, short horse }\end{array}$ & $\begin{array}{l}1 \text { dan? dou of } \\
\text { coarse grains }\end{array}$ & $\begin{array}{l}1 \text { dan? dou } \\
\text { of coarse } \\
\text { grains }\end{array}$ \\
\hline
\end{tabular}

191 Russian Collection of Khara-Khoto Manuscripts, vol. 12, p. 141.

192 Shi Jinbo, 2008. 
CHART 15 Data in Khara-Khoto livestock sale contracts (cont.)

\begin{tabular}{|c|c|c|c|c|}
\hline Register & Date & Livestock & Price & $\begin{array}{l}\text { Price in } \\
\text { coarse grains }\end{array}$ \\
\hline Инв. No. 2546-1 & $\begin{array}{l}\text { Hai Year of } \\
\text { Tianqing (1203) } \\
\text { 3oth Day of the } \\
\text { 2nd Month }\end{array}$ & $\begin{array}{l}1 \text { full-teethed } \\
\text { female camel }\end{array}$ & $\begin{array}{l}6 \text { dan of } \\
\text { coarse grains }\end{array}$ & $\begin{array}{l}6 \text { dan of } \\
\text { coarse grains }\end{array}$ \\
\hline Инв. No. 5404-8, 9 & $\begin{array}{l}\text { Jiazi Year of } \\
\text { Tianqing (1204) } \\
\text { 15th Day of the } \\
\text { 11th Month }\end{array}$ & $\begin{array}{l}\text { A mare with } \\
\text { bridle }\end{array}$ & $\begin{array}{l}5 \text { dan of } \\
\text { coarse grains }\end{array}$ & $\begin{array}{l}5 \text { dan of } \\
\text { coarse grains }\end{array}$ \\
\hline Инв. No. 5404-10 & $\begin{array}{l}\text { Zi Year of } \\
\text { Tianqing (1204) } \\
\text { 16th Day of the } \\
\text { 11th Month }\end{array}$ & $\begin{array}{l}1 \text { five-teethed } \\
\text { usable maroon } \\
\text { horse }\end{array}$ & $\begin{array}{l}4 \text { dan of } \\
\text { coarse grains }\end{array}$ & $\begin{array}{l}4 \text { dan of } \\
\text { coarse grains }\end{array}$ \\
\hline Инв. No. $285^{8-1}$ & $\begin{array}{l}\text { Chou Year of } \\
\text { Tianqing (1206) } \\
\text { 3oth Day of the } \\
\text { 12th Month }\end{array}$ & $\begin{array}{l}\text { Four-teethed, } \\
\text { usable, red mare }\end{array}$ & $\begin{array}{l}7 \text { dan of } \\
\text { coarse grains }\end{array}$ & $\begin{array}{l}7 \text { dan of } \\
\text { coarse grains }\end{array}$ \\
\hline Инв. No. $7630-2$ & $\begin{array}{l}\text { You Year of } \\
\text { Guangding (1213) } \\
\text { 3oth Day of the } \\
5 \text { th Month }\end{array}$ & $\begin{array}{l}1 \text { four-teethed } \\
\text { live cattle }\end{array}$ & $\begin{array}{l}4 \text { dan of } \\
\text { coarse grains }\end{array}$ & $\begin{array}{l}4 \text { dan of } \\
\text { coarse grains }\end{array}$ \\
\hline Инв. No. 7994-14 & $\begin{array}{l}\text { Hai Year of } \\
\text { Guangding (1215) } \\
\text { 27th Day of the } \\
\text { 3rd Month }\end{array}$ & $\begin{array}{l}\text { 1 six-teethed } \\
\text { cattle }\end{array}$ & $\begin{array}{l}\text { 1o dan ( } 1 \text { dan } \\
\text { paid, } 8 \text { dan } \\
\text { due by the } \\
6 \text { th month) }\end{array}$ & 10 dan \\
\hline Инв. No. 6377-15 & $\begin{array}{l}\text { Zi Year of } \\
\text { Guangding }(1216) \\
\text { 16th Day of the } \\
5 \text { th Month }\end{array}$ & $\begin{array}{l}1 \text { two-vertical } \\
\text { (teethed) } \\
\text { female camel, } \\
6 \text { female camels, } \\
1 \text { vertical } \\
\text { (cattle?), } \\
1 \text { maroon horse }\end{array}$ & $\begin{array}{l}\text { 9o liang of } \\
\text { silver }\end{array}$ & $\begin{array}{l}\text { 1o guan of } \\
\text { cash }\end{array}$ \\
\hline
\end{tabular}

In both livestock sale contracts found in Wuwei, the livestocks are paid for in cash. 
CHART 16 A list of livestock sale contracts unearthed in Wuwei

\begin{tabular}{llll}
\hline Register & Date & Livestock & Price \\
\hline G31.003 $[6727] 1-2$ & $\begin{array}{l}\text { ?th day of 9th month in the } \\
\text { You Year of Qianding }(1225)\end{array}$ & $\begin{array}{l}\text { 1 full-teethed } \\
\text { black cattle }\end{array}$ & 65 guan in cash \\
G31.002 $[6726]$ & $\begin{array}{l}\text { 8th day in the 4th month, } \\
\text { Xu Year of Qianding }(1226)\end{array}$ & 1 yellow donkey & 50 guan in cash \\
& &
\end{tabular}

Livestock sale contracts are the most direct access to the actual market prices of livestocks. There is price variation not only between different commodities, but also based on the age, gender, strength, and other qualities of the livestocks in question. Therefore, pricing is much more complex in the case of livestocks than in grains. Besides, different timing and location also affect the transaction prices. At times, the livestocks are sold in bundles and packages. Therefore, the contracts only record the total price, rather than the unit price. These scenarios further add to the difficulty of recovering market prices. As always, it is easier to at least convert all grains into coarse grains, to make it easier to calculate and analyse pricing where livestocks are exchanged for grains.

Livestock sale contracts that deal with only one kind of animal are the easiest to analyse. Manuscript Инв. No. 5124-4(5), for example, gives the price of a two-teethed male camel as 3 dan of coarse grains; Инв. No. 2546-1 reveals the price of a full-teethed female camel as 6 dan; in Инв. No. 5404-8, 9, a mare is sold for 5 dan; from Инв. No. 5404-10, we know that the unit price of a five-teethed, usable, maroon horse is 4 dan; Инв. No. 2858-1 tells us that a four-teethed, usable, red mare is worth 7 dan; Инв. No. $7630-2$ indicates the price of a four-teethed cattle as 4 dan; whereas in Инв. No. 7994-14, a six-teethed cattle is sold for 10 dan. A preliminary analysis of the data gives us the basic price ranges: the price of a camel is between 3 and 6 dan of coarse grains, with a female often slightly more expensive than a male. A horse is worth 4-7 dan, and the mare also costs more than a stallion. Cattle price is trickier. A cattle sale contract shows that a cattle costs 4 dan of coarse grains, whereas in Инв. No. 7994-14, where the buyer, rather than the seller is the main contracting party, the six-teethed cattle is transacted for 10 dan in installment. At the signing of the contract, the seller receives a down payment of 1 dan, and expects another 8 dan by the sixth month. It is also strange that the sum of the two payments is 9, rather than 10 dan in total. It looks like the contract misses content near the end. Nor does it feature the signatures and stamps of the main parties to contract. Therefore, it could be seen as an incomplete and invalid contract. 
The price it lists, therefore, is less than reliable. The typical unit price of cattle is slightly less than that of camels and horses, around 3-5 dan.

With the unit prices at hand, it is now possible to study the wholesale prices of livestocks sold in a bundle or package. In the Инв. No. 5124-3(5, 6) manuscripts, 2 full-teethed cattles, and one that is full-teethed and black, are sold altogether for 5 dan of wheat and 2 dan of coarse grains $=8.6$ dan of coarse grains. Holding traits such as colours constant, each cattle is worth 3 dan of coarse grains, on average. In the Инв. No. 5124-4(4) contract, a full-teethed female camel and a horse are sold for 2 dan of wheat and 3 dan of coarse grains $=5.7$ dan of coarse grains, where the average price of each livestock is within 3 dan. We see that the average wholesale prices here are lower than the unit prices of the animals. In fact, these two wholesale contracts are not market transactions but the acquisitions of livestocks by the Pudu Temple. The temple's agents bargained for a discount, taking advantage over livestock-owners desperate to sell livestocks for grains.

Livestocks are also paid for in cash. In contract No. 6377-15, for instance, a total of 9 livestocks: a 2-vertical(-teethed) female camel, 6 female camels, 1 vertical(-teethed ?), a maroon horse, are sold for 9o liang in silver. The average price of each animals is 10 liang. If we allow that the average price of any large livestock is around 5 dan of coarse grains, then 1 dan of coarse grains $\approx 2$ liang of silver.

Payments are in cash in both Wuwei livestock contracts. In G31.003[6727]12 , an ox/cow is sold for 65 guan; in G31.002 [6726], a donkey is sold for 5 o guan. Transactions in Khara-Khoto contracts, however, are generally done in grainsthat is, in kinds rather than in cash. There, we see a difference in the economic lives of Wuwei and Khara-Khoto. Wuwei counts as the 'second best city' after the imperial capital Zhongxing. Wuwei boasts a commerce-based cash economy that is more advanced than Khara-Khoto. Statements in IOU debt bills found in Xiaoxigouxian, Wuwei: "Li Banchu owes 3 strings and 500 wen"; "Liu Dede owes 2 strings and 250 wen" show that "cash was in circulation." 193 It should not be assumed, however, that there was no cash flow in Khara-Khoto. Three contracts of human sales in Khara-Khoto, Инв. No. 5949-29, 4597 and 7903, are all transacted in cash.

Another way to make sense of livestocks sale is to compare prices in cash and in kinds. We have established, in the chapters on grain prices, that each

193 Museum of Gansu. “Gansu Wuwei Faxian Yipi Xixia Yiwu” [甘肅武威發現一批西夏 遺物]: “A Batch of Tangut Materials has been Discovered in Wuwei, Gansu” in Kaogu [考古]: Archaeology, issue 3, 1974 . 
dou of coarse grains costs 150-20o mace, or 1.5-2 guan..$^{194}$ In the first contract, an ox/cow costs 65 guan in cash, that is an unreasonably high 32-43 dan in coarse grains. It could only be explained in contexts of high inflation caused by socioeconomic instabilities. In the third year of Daqing (1142), in the ninth month, "there is a famine in Western Xia, where the grain price rose to a hundred mace per sheng." 195 The price of grain is 1 guan/dou, or 10 guan/dan, soaring past 4-5 times the normal price. Grain price during the reign of Renzong Emperor of Northern Song is 6oo-70o mace per dan. Later, it rose to the level of 1 guan and 250 wen. In Southern Song, it increased to around 2 guan, and at times, even 10 guan per dan.

The Wuwei contracts are dated to the You (1225) and Xu (1226) Years of Qianding, both in the late Tangut period, only a year or two before the empire fell to the Mongols (1227). By this time, the Hexi Corridor was under constant threat from the Mongol army. The twilight of Tangut power witnessed incessant wars with the Mongols and the Jurchens. In 1225, the year $\mathrm{G}_{31}{ }^{\circ} 003[6727] 1-2$ contract was signed, the Mongol army once again invaded Western Xia. In the second month of the following year, Genghis Khan led an army 100,00o strong into Tangut territories, taking Khara-Khoto, Wulahai (Uraqai), and then Shazhou. ${ }^{196}$ The Mongols breached the walls of Suzhou in the fifth month, and entered Ganzhou in the following month. In the seventh month, they stormed Xiliang (present-day city of Wuwei, Gansu). Terrorised by the unstoppable force of Genghis Khan, Xianzong Emperor of Western Xia passed away in fright. The Wuwei contract $\mathrm{G}_{31} \cdot{ }^{\circ}{ }^{\circ}{ }^{2}\left[6_{72} 6\right]$ is dated to that year, when Khara-Khoto and Dunhuang were under siege, a mere 3 months before Wuwei would fall. It was, in short, a time of turmoil along the Hexi Corridor, and of the utmost insecurity in the Tangut society. Inflation of commodity prices and devaluation of currency value are the natural consequence of these historical episodes. Whether it is the grains or the livestocks, all prices soared. Under such circumstances, it was much easier to maintain the price ratio by trading in kinds rather than in cash. So, one would understand why the cattle is sold for 65 guan in cash. If it were priced 3-5 dan, then at the rate of 13-20 guan per dan, the cost would have exceeded the grain prices during the Lin'an famine.

194 Shi Jinbo, 2008.

195 Xixia Shushi, Ch. 35.

196 TN: See Dunnell, Ruth. "Locating the Tangut Military Establishment: Uraqai (Wulahai) and the Heishui Zhenyan Army" Monumenta Serica, 1992, pp. 219-234. 


\subsubsection{Guarantee of the Contract \\ 3.2.3.1 Penalty for Breach of Contract}

Most livestock sale contracts specify the procedures and penalties in case any financial dispute should arise. Since large livestocks are key assets in the Tangut economy, there may be legal challenges to their ownership from family relatives, or members in the same military chao as the legal or putative owner. To preempt the chaos and complexities of legal disputes, the contracts stipulate where liability falls: it is always the seller, rather than the buyer, who bears the responsibility. In addition, some contracts require that the seller pay a penalty fee in either grains or cash. The sum usually falls below the sale price. Another arrangement is to double the sum of the sell \& purchase price. Some contracts include both kinds of penalties, while others adopt only one of the two stipulations. Besides, if a party regrets over the transaction and reneges on its promises, there would also be a penalty. It seems as if this last requirement is the result of bipartisan negotiations and mutual consensus. However, it often turns out to be a way for the buyer to restrain the seller. Below is a chart that compiles all data on penalties from the 13 Khara-Khoto livestock sale contracts. Given the connection between sale price and penalty fee, it also lists the prices as a point of comparison.

CHART 17 Penalty fees in contracts of livestock sale

\begin{tabular}{lllll}
\hline Register & $\begin{array}{l}\text { Livestock } \\
\text { price }\end{array}$ & $\begin{array}{l}\text { Price in } \\
\text { coarse } \\
\text { grains }\end{array}$ & $\begin{array}{l}\text { Penalty for seller in } \\
\text { case of dispute }\end{array}$ & $\begin{array}{l}\text { Penalty for } \\
\text { the reneging } \\
\text { party }\end{array}$ \\
\hline
\end{tabular}

\begin{tabular}{|c|c|c|c|}
\hline $\begin{array}{l}\text { Инв. No. 5124-3 } \\
(5,6)\end{array}$ & $\begin{array}{l}5 \text { dan of } \\
\text { wheat \& } \\
2 \text { dan of } \\
\text { coarse grains }\end{array}$ & $\begin{array}{l}\approx 8.6 \text { dan } \\
\text { of coarse } \\
\text { grains }\end{array}$ & $\begin{array}{l}\text { Penalty Fee: } 5 \text { dan of } \\
\text { wheat }\end{array}$ \\
\hline $\begin{array}{l}\text { Инв. No. 5124-4 } \\
\text { (4) }\end{array}$ & $\begin{array}{l}2 \text { dan of } \\
\text { wheat, } 3 \text { dan } \\
\text { of coarse } \\
\text { grains }\end{array}$ & $\begin{array}{l}\approx 5.7 \text { dan } \\
\text { of coarse } \\
\text { grains }\end{array}$ & $\begin{array}{l}\text { Criminal Liability in } \\
\text { accordance with the } \\
\text { Laws and Orders, plus } \\
\text { penalty fee of } 3 \text { dan of } \\
\text { wheat }\end{array}$ \\
\hline $\begin{array}{l}\text { Инв. No. 5124-4 } \\
(5)\end{array}$ & $\begin{array}{l}2 \text { dan of } \\
\text { barley, } 1 \text { dan } \\
\text { of millet }\end{array}$ & $\begin{array}{l}3 \text { dan of } \\
\text { coarse } \\
\text { grains }\end{array}$ & $\begin{array}{l}\text { Criminal Liability in } \\
\text { accordance with the } \\
\text { Laws and Orders, plus } \\
\text { penalty fee of } 2 \text { dan of } \\
\text { coarse grains }\end{array}$ \\
\hline
\end{tabular}


CHART 17 Penalty fees in contracts of livestock sale (cont.)

\begin{tabular}{|c|c|c|c|c|}
\hline Register & $\begin{array}{l}\text { Livestock } \\
\text { price }\end{array}$ & $\begin{array}{l}\text { Price in } \\
\text { coarse } \\
\text { grains }\end{array}$ & $\begin{array}{l}\text { Penalty for seller in } \\
\text { case of dispute }\end{array}$ & $\begin{array}{l}\text { Penalty for } \\
\text { the reneging } \\
\text { party }\end{array}$ \\
\hline Инв. No. 2546-2, 3 & $\begin{array}{l}1 \text { dan? of } \\
\text { coarse grains }\end{array}$ & $\begin{array}{l}1 \text { dan? } \\
\text { dou of } \\
\text { coarse } \\
\text { grains }\end{array}$ & Seller liable & $\begin{array}{l}\text { Penalty Fee: } \\
5 \text { dan of } \\
\text { coarse grains }\end{array}$ \\
\hline Инв. No. 2546-1 & $\begin{array}{l}6 \text { dan of } \\
\text { coarse grains }\end{array}$ & $\begin{array}{l}6 \text { dan of } \\
\text { coarse } \\
\text { grains }\end{array}$ & Seller liable & $\begin{array}{l}\text { Penalty Fee: } \\
1 \text { dan } 5 \text { dou of } \\
\text { coarse grains }\end{array}$ \\
\hline Инв. No. 5404-8, 9 & $\begin{array}{l}5 \text { dan of } \\
\text { coarse grains }\end{array}$ & $\begin{array}{l}5 \text { dan of } \\
\text { coarse } \\
\text { grains }\end{array}$ & (Missing?) & $\begin{array}{l}\text { Penalty Fee: } \\
5 \text { dan of } \\
\text { coarse grains }\end{array}$ \\
\hline Инв. No. 5404-10 & $\begin{array}{l}4 \text { dan of } \\
\text { coarse grains }\end{array}$ & $\begin{array}{l}4 \text { dan of } \\
\text { coarse } \\
\text { grains }\end{array}$ & (Missing) & Missing \\
\hline Инв. No. $285^{8-1}$ & $\begin{array}{l}7 \text { dan of } \\
\text { coarse grains }\end{array}$ & $\begin{array}{l}7 \text { dan of } \\
\text { coarse } \\
\text { grains }\end{array}$ & Seller liable & Missing \\
\hline Инв. №. $763^{\circ-2}$ & $\begin{array}{l}4 \text { dan of } \\
\text { coarse grains }\end{array}$ & $\begin{array}{l}4 \text { dan of } \\
\text { coarse } \\
\text { grains }\end{array}$ & $\begin{array}{l}\text { Seller liable, penalty } \\
\text { fee: } 8 \text { dan of coarse } \\
\text { grains }\end{array}$ & \\
\hline Инв. No. 7994-14 & $\begin{array}{l}10 \text { dan ( } 1 \text { dan } \\
\text { paid, } 8 \text { dan to } \\
\text { be paid in the } \\
6 \text { th month) }\end{array}$ & 10 dan & $\begin{array}{l}\text { Seller liable, penalty } \\
\text { fee: } 2 \text { dan per } 1 \text { dan of } \\
\text { sale price }\end{array}$ & $\begin{array}{l}3 \text { dan of } \\
\text { coarse grains }\end{array}$ \\
\hline Инв. No. $6377^{-15}$ & $\begin{array}{l}\text { 9o liang of } \\
\text { silver }\end{array}$ & & Seller liable & $\begin{array}{l}\text { Penalty Fee: } \\
\text { 1o guan of } \\
\text { cash }\end{array}$ \\
\hline 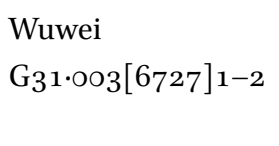 & $\begin{array}{l}65 \text { guan of } \\
\text { cash }\end{array}$ & & $\begin{array}{l}\text { Penalty Fee: } 1 \text { guan } \\
\text { per } 2 \text { guan of sale } \\
\text { price }\end{array}$ & $\begin{array}{l}\text { Penalty Fee: } \\
30 \text { guan of } \\
\text { cash }\end{array}$ \\
\hline $\begin{array}{l}\text { Wuwei } \\
\mathrm{G}_{31 \cdot 002[6726]}\end{array}$ & $\begin{array}{l}5^{\circ} \text { guan of } \\
\text { cash }\end{array}$ & & Seller liable & $\mathrm{n} / \mathrm{a}$ \\
\hline
\end{tabular}


Most contracts are unequivocal on the point of seller liability. Others, which do not state in explicit terms that the seller is the sole liable party, nonetheless stipulate that the seller pay penalty fees under certain circumstances. The implication is the same, that the seller is responsible should any dispute arise. Some penalty fees are set below the sale price. In the long scroll Инв. No. 5124, penalty fees are lower than the sale prices. In manuscripts Инв. No. $763^{\mathrm{o}-2}$, 7994-14, and $\mathrm{G}_{31} \cdot{ }^{\circ} 0_{3}\left[6_{727}\right]_{1-2}$, however, the penalty is twice as much as the sale price. Whilst some contracts such as No. 5124 do not specify any penalty against reneging on the terms of the contract, other contracts indicate the penalty fee in precise numbers, which are typically less or equal to the sale price. In Инв. No. 2546-2, 3, where the sale price is very low, the penalty fee is much higher.

As always, the expression "willing" or "own heart willing" refers to the seller's acknowledgement of the terms set in the contract, especially the terms of penalties.

Terms of penalties in livestock sale contracts are more complex than in grain loan accounts, and less so than in land sale contracts. The force and amount of penalty is greater than in grain loans and less than in land sales. Of course, these patterns of difference have everything to do with the nature of the contract, the value of the commodity, and the volume of transaction in question. Grain loan documents are records of borrowing and lending, whereas land and livestock transactions are 'absolute sales' - the transfer of titles from one property-owner to another. Within the scope of absolute sales, land is worth more than livestocks. Therefore, the penalties in one are more severe than in the other. Penalty fees in gold are found only in land sale contracts, and nowhere else.

\subsubsection{Signature, Stamp, and Seal}

Tangut livestock sale contracts are unilateral legal documents. In other words, they are kept in the possession of one party - usually the buyer-rather than by both parties. To signal the seller's approval and acknowledgement, the name of the main contracting party has to appear at the end of the contract. The seller also has to produce a stamp, either an icon or the shape of his finger segments, along with the co-contractors and the witnesses. As in land sale and lease contracts, each signature or stamp takes up a separate line near the end of the contract. The order is also the same: firs the main contracting party, then the co-liable associates, followed by the witnesses. Stamping conveys the solemn pledge of faith and knowledge to the agreement. Since the signatures 
are often written by a professional transcriber, the stamps are the only way to authenticate a contract.

The Инв. No. $7630-2$ contract of cattle sale dated to the You Year of Guangding (1213) features the red seal of the Department of Transaction Taxes. "Red contracts" are rare amongst Tangut contracts. Of all 12 land sale contracts, only Инв. No. 5010 dated to the 22nd year of Heavenly Prosperity is a "red seal." The seal of the Department of Transaction Taxes produces a $23.2 \times 7.3 \mathrm{~cm}$ rectangular stamp with images of lotus leaves and flowers. The stamp reads 較较 䊽㥢 (lit. Department of Sell and Purchase Taxes). The stamp shows that this one-time transaction is approved and taxed by the government.

\subsubsection{Features of Livestock Sale Contracts}

The impressive corpus of Khara-Khoto livestock contracts reveals a wealth of details on how livestocks are exchanged in Western Xia. First, these contracts give us the market prices of large livestocks such as horses, camels, and cattles. They shed some light on the causes of price variations. A comparison of the Khara-Khoto and Wuwei contracts, where animals are paid for in grains and in cash, respectively, also confirms our prior understanding of the differences between the Khara-Khoto and the Wuwei economies. Secondly, the livestock sale contracts provide a perspective on the soaring commodity prices and hyper inflation in the late Tangut period, as the Mongol army invaded and the Tangut imperium crumbled. Thirdly, whereas some transactions are normal exchanges at market prices, others are acquisitions by large property-owners at the expense of peasant farmers who have to sell their livestocks for foodstuff. Finally, a comparison between livestock loan and livestock sale contracts shows that the Pudu Temple not only amassed assets, but also issued lucrative loans to impoverished peasants in hardship. In a year or two, the temple could have acquired the livestocks for free. The monastery's acquisitive and exploitative ventures further exacerbated wealth inequality, driving propertyless peasants to the path of deprivation and desperation.

\subsection{Transaction of Humans}

Three rare Khara-Khoto contracts of human sales reveal the peculiar phenomenon of human transactions in Western Xia, an important primary source on the nature and the lived experiences of the Tangut society. 


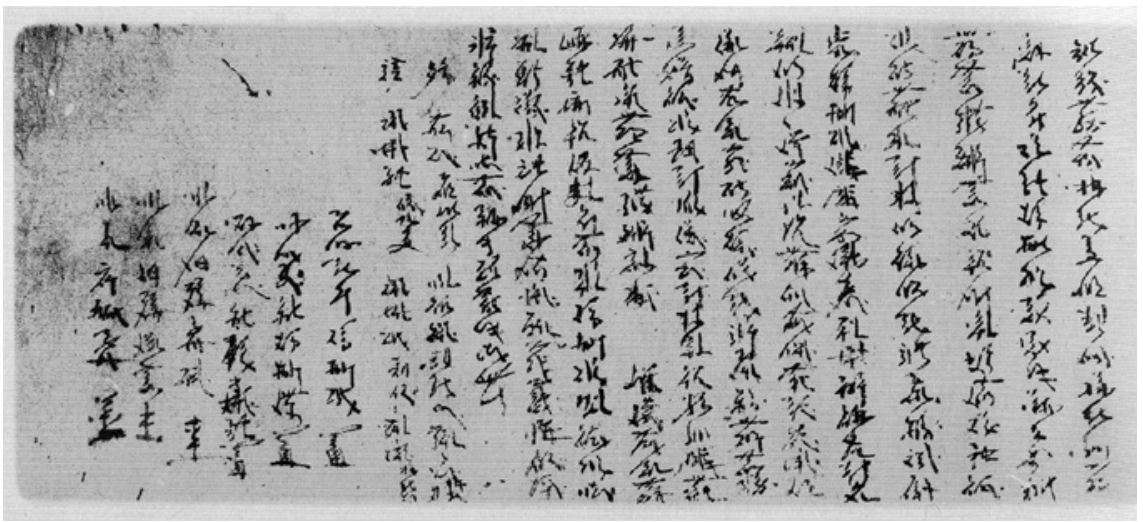

FIGURE 176

Инв. No. 5949-29: Jiachen 27th year of Qianyou. Contract of Shijun/Nupu sale Note: TN: There are only 24 years in the Qianyou Reign.

1. Инв. No. 5949-29: Contract of Shijun/Nupu Sale in the Jiachen, 27th year of Qianyou is an individual contract of 20 lines in cursive Tangut written on a $20.3 \times 55.2 \mathrm{~cm}$ hemp paper. It is a fragment with some parts missing. The text begins with the date, 2 oth day of the 3 rd month, and ends with signatures and stamps. ${ }^{197}$

Translation:

On the 24th day of the 3rd month in the Jiachen, 27th year of Qianyou,

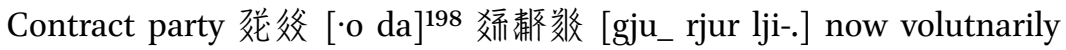
sells his own

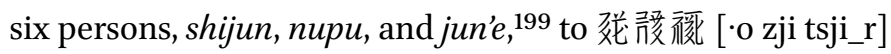

敂 [lji-. $]^{200}$ at the price of 450 guan of iron coins, ${ }^{201}$ hereby agreed upon.

197 Russian Collection of Khara-Khoto Manuscripts, vol. 14, p. 91.

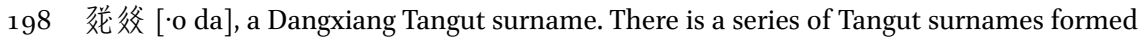
by adding numbers, from one to eight, onto the character 茬. See Shi, Jinbo. Xixia Wenhua [西夏文化]. Changchun: Jilin Education Press, 1986, p. 185.

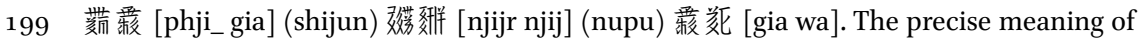
the third and last category remains unclear, but it is a social class, status, and identity parallel to the semi-slaves and servants.

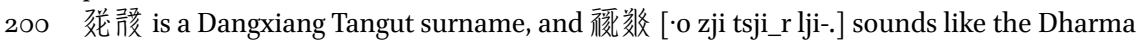
name of a monk.

201 㒸譒 [śjow dzji-j] iron coins. Both copper and iron coins were circulated in Western Xia. Copper coins were worth more than iron coins. 


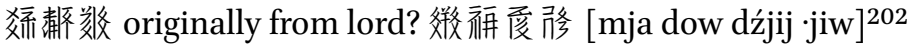
not? clothes, hands ?? only? in? ${ }^{203}$

? ? holds 450 guan iron coins, ??

Inspected by ?? Both the payment and the persons have by this day

been transferred. In case a dispute erupts over these shijun and nupu,

either by the government or by private individuals, such as members of the same chao

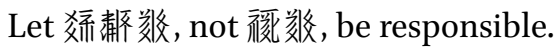

Let any party that breaches the contract be judged by the Bureau of

Military Supervision to which he belongs; let him not only be fined

5 oo guan in cash, but also tried in accordance with the Laws and Orders.

Hearts willing.

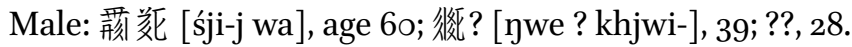

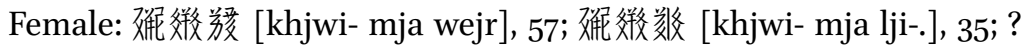
难 [khjwi-], 23.

Contract Party: 㹡邦敬 [gju_rjur lji-.] (stamp)

Co-contractor: son, 娇邦莿 [gju_rjur khwej] (stamp)

Co-contractor: son, ?? 学严 [wejr] (stamp)

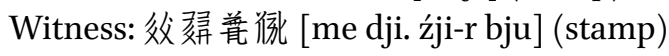

Witness: 效峐微? [me dji. bie_j ?] (stamp)

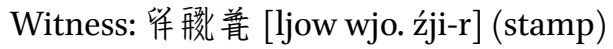

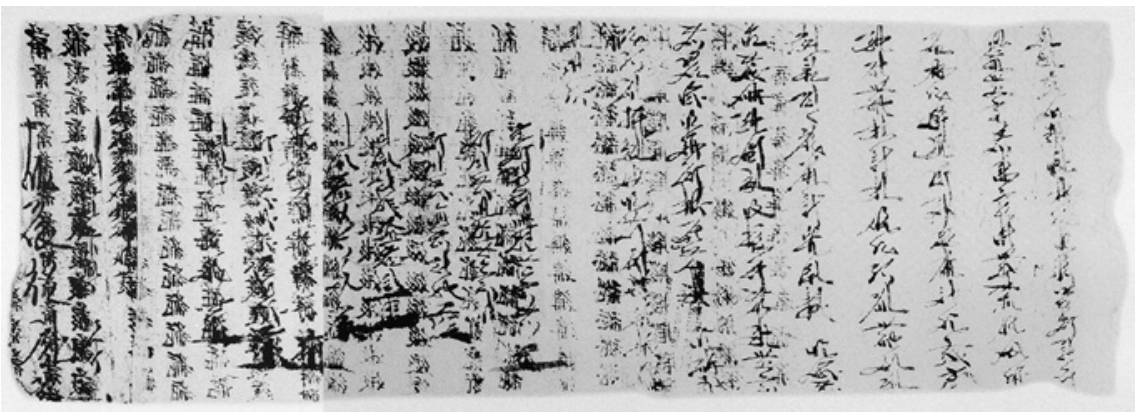

FIGURE 177

Инв. No. 4597: Wei year of Tianqing (1199) contract of Shijun sale

2. Инв. No. 4597: Contract of Shijun Sale in the Wei Year of Tianqing (1199) is an individual contract with 19 lines of cursive Tangut written on a $20.4 \times 57.8 \mathrm{~cm}$ hemp paper. The ink is light and blurry, further muddled and riddled by the

202 徉释 [mja le] is likely to have been the family name here.

203 TN: most of this line is illegible. 
sutra text written on the back of the paper. The contract begins with the date,

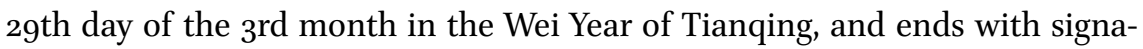
tures and stamps. ${ }^{204}$

Translation:

On the 24th day of the 3rd month in the Wei Year of Tianqing, the Contract Party

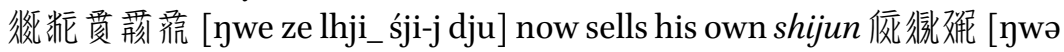
lhji. khjwi-]

et al., two persons young and old, volutnarily sold to ?? 茯席剙 [?? yji-. njij wejr] according to the terms of this contract,

At the price of 5 o dan of coarse grains, already paid. Neither the persons

Nor the grains are amiss. If external parties initiate public or private disputes,

Such as members of the same chao, let ? 荊芿

Be responsible. Let any party that reneges on its promises pay a penalty, according to the laws of the government,

In the amount of 30 dan of coarse grains. Heart willing. ${ }^{205}$ Let the terms be enforced according to the contract and the circumstances.

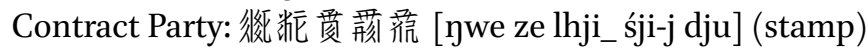

Co-contractor: 後 ?? [ Đwe ze lhji_??]

Co-contractor: 後䉼茫绫? [ ywe ze dju zji wejr] (stamp)

Witness: 胗很??微 [-jiw dji.j ?? bie_j] (stamp)

Witness: ???? (stamp)

Contract written by 预敚嗳 [tśhiə lji-. wejr] (stamp)

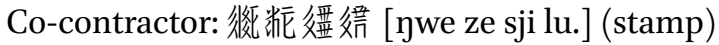

Witness: ???? (stamp)

204 Russian Collection of Khara-Khoto Manuscripts, vol. 13, p. 223.

205 绎坂落 [nji_j lja_w2_], lit. "heart, mouth, submit” i.e. the party is willing, at heart or in his mind. 


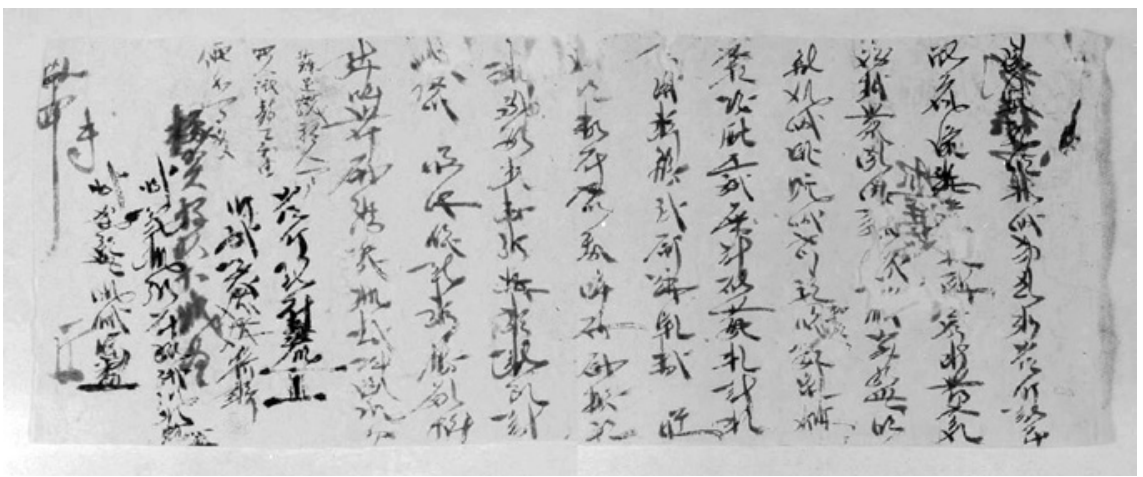

FIGURE 178 Инв. No. 7903: Wu year of Huangjian (1210) Su [??] contract of Shijun sale

3. Инв. No. 7903: Contract of Shijun Sale in the Wu Year of Huangjian (1210). The manuscript fragment features of 16 lines of cursive Tangut handwritten on a $18 \times 44.8 \mathrm{~cm}$ hemp paper. The ink on the page are soaked from the other side of paper. The contract begins with the date, 3 rd day of the 2 nd month in the Wu Year of Huangjian (1210), and ends with signatures and stamps. There are traces of erasures, as well as three lines of Chinese characters in a smaller font. 206

Translation:

On the 3rd day of the 2nd month in the Wu Year of Huangjian, Contract Party

Su ??? presently sells his own shijun

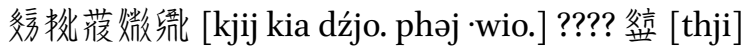

sons 彻很徽 [gji-_lhji. bie_j], [tśjow lhji. śji-j] et al., four persons in total, sold

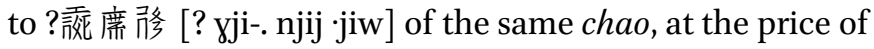
the agreed price of 100 guan. If either party initiates a public or private dispute, or reneges on the agreement, let not only the penalty be double the sale price, but let the relevant party pay 50 guan according ot the laws.

Own hearts willing. Terms to be enforced according to the contract and the circumstances.

(3 lines of Chinese characters in a small font above, 1 line in a larger font) $)^{207}$ (Signatures in Tangut, stamps)

206 See Russian Collection of Khara-Khoto Manuscripts, vol. 14, pp. 221-222.

207 TN: The Chinese text is as follows: 蘇足說?私人一戶/四人? 轉王?和由/價錢一百貫/ 楊賀好???? 


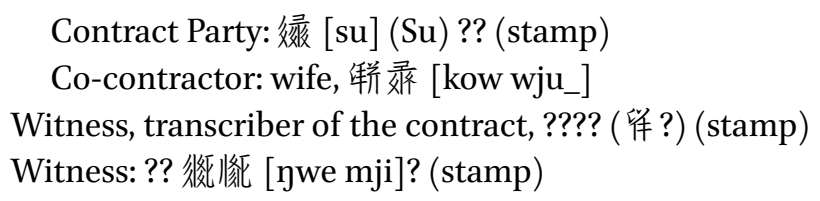

\subsubsection{Format and Content of Human Transaction Contracts}

Contracts of human transactions follow the same general format of Tangut contracts. Each line begins without indentation, first with the date, month, and year, then the names of the main contract party, followed by the names, number, and prices of the human beings being sold. The contract lays out the terms on which to transfer the persons from one owner to another, to address the rights of families and neighbours, and to allocate liability. The contract ends with the signatures and stamps of the principle parties and the guarantors.

\subsubsection{Time}

The date recorded in the Инв. No. 5949-29 manuscript, "24th day of the 3rd month in Jiachen, the 27th year of Qianyou" is erroneous, for there are only 24 years in the Qianyou era of Western Xia. The Jiachen year of Qianyou is, in fact, the 15th year of Qianyou (1184). But if we were to extend the years from the 24th year of Qianyou onward, for three additional years, we arrive at a fictional '27th year of Qianyou,' which is in fact the Bingchen, 3rd year of Tianqing (1196). The second contract in the Инв. No. 4597 manuscript is dated to the 24th day of the 3rd month in the Wei Year of Tianqing, or Jiwei, the 6th year of Tianqing (1199). The contract in manuscript Инв. No. 7903 is signed on the $3^{\text {rd }}$ day of the 2nd month, in the Wu Year of Huangjian, or Gengwu, the first year of Huangjian (1210). All three contracts are dated to the late Tangut period, only 17 years before the dynasty came to its end. And all three contracts are signed in the second and third months, which is also the inter-harvest period when the Tanguts tend to take out grain loans, and to sell their land, livestocks, as well as other properties.

\subsubsection{Sellers and Buyers of Human Beings}

By the Laws of Heavenly Prosperity, it is necessary to make contracts in order to transact human beings such as shijun and nupu:

Let the many who loan or sell their own shijun, nupu, farmland, and houses to other parties make contracts. ${ }^{208}$

208 Revised Laws of Heavenly Prosperity 11, "On Hired Labour," no. 390. 
The Laws of Heavenly Prosperity categorises the serfs, servants, and semislaves such as shijun and nupu into the same class of private property as farmland and houses. As usual, the contracting parties named and signed in the contracts are the sellers, or the previous owner of the persons to be sold. Of

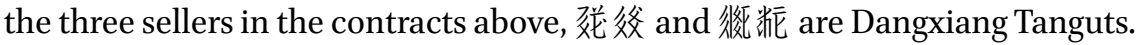
The third has a Chinese name, $\mathrm{Su}$ (娽 $=$ 蘇).

All three buyers seem to be ethnic Dangxiang Tanguts. 娆語 is a classic Dang-

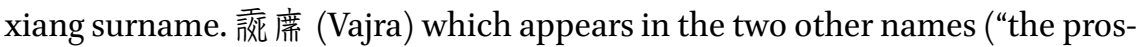

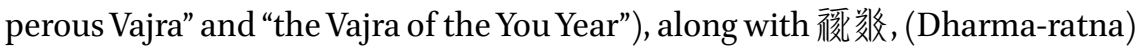
invokes Buddhist ideas and imageries.

\subsubsection{Identities, Quantities, and Prices of the Humans Sold}

The commodities transacted in these contracts are humans, rather than inanimate properties. The Khara-Khoto contracts of human transactions records the numbers and conditions of the persons being traded, but not the reasons for them to be bought and sold. Some, though not all of the Dunhuang contracts of human transactions, however, do state the reasons. For example, in the Bingzi year (916), Awu sells her son, "because the husband dies early, all the males, females, and children, are deep in debt, unprovided for food and clothing."209

The Khara-Khoto contracts of human transaction are written in cursive and damaged writings that are by no means easy to identify. As a result, many names remain illegible. A total of 6 persons, 3 men and 3 women, are sold by the Инв. No. 5949-29 document. They seem to be either one and the same family, three separate couples, or six unrelated individuals. In Инв. No. 4597, there could be 2 shijun being sold. One of the two names is unidentifiable. Nor do we know their gender as a matter of fact. In Инв. No. 7903, there seems to be a couple with their two sons. We know they belong to the same family from the Chinese characters near the end of the contract. Due to his low social status, the shijun is registered in files and documents with his first name only, without a last name.

In the first contract, the 6 persons are sold for 450 guan in iron coins; in the second, the two persons are sold for 50 dan of coarse grains; in the third, the four persons are sold for 10o guan in cash.

209 Tang and Lu (eds.). Dunhuang Economic Documents II, pp. 47-49. 


\subsubsection{The Guarantee of Contracts \\ 3.3.3.1 Penalty Fee}

The Laws of Heavenly Prosperity issue penalties against the renegation of contract at different levels, in various stages of the process:

If the seller or lender changes his words at a time when the loan is not taken or the payment not yet made, let an office-holder be fined a horse, and let a commoner suffer 13 strokes; if the loan is taken or the payment made, and yet a party claims the contrary, and whereby reneges on its promise, let the case by tried in accordance with the laws on renegation in the case of debt payment; if the transaction is not completed, but a party claims that the loan or good has been purchased, and in this way seeks to acquire it, or if the loan or good is purchased, but a party claims that it has not, let the case be tried in accordance with the laws on renegations in debt payment, as well. ${ }^{210}$

All the three contracts of human transaction make clear that in cases of any dispute, the seller bears full liability. If a party reneges on the agreement, the penalty fee is 500 guan in the first contract (and a trial in accordance with the Laws and Orders), 30 dan of coarse grains (and criminal liability according to the circumstances) in the second contract, and double the sell \& purchase price, plus 50 guan of penalty fee, in the third contract.

\subsubsection{Signatures and Stamps}

Contracts of human transactions are important legal records of absolute sales. Therefore, there tend to be more co-contractors and witnesses. There are 2 co-sellers and 3 witnesses in the first contract; 3 co-sellers and 3 witnesses in the second contract; 1 co-seller and 2 witnesses in the third contract. As usual, the signatures are written by a professional, rather than by the signatories themselves. So, the stamps are the only source of identification, legitimation, and authentification. In all three contracts, the signatories produced their icons. Only the main contracting party's wife does not produce any stamp in the third contract. The use of icons, instead of finger segments, shows the formality of these contracts.

\subsubsection{Human Transactions in Western Xia}

In general, the historical practice of trading and transacting persons takes place in slave societies where human beings are owned by slave-owners. The

210 Revised Laws of Heavenly Prosperity 11, p. 390. 
slave-owner exercises property rights and imposes supra-economic power over the enslaved. Therefore, the slaves are private properties without persona liberty. In feudal societies of China, the personal attachment of the yeomen, tenant farmers, and semi-independent peasants to the landlord is rather weak. Therefore, for long periods of time, the laws forbid the transaction of human beings. However, this type of feudal society remains a society of caste. Human transaction persists as a marginal phenomenon under the regime of class and status.

The premise of human transaction is full ownership and property right over human beings. There have always existed small groups of human beings who do not entirely own their own legal persons. The unfree, such as the buqu (部曲) and nubi (奴婢) have always been exchanged as commodities. Moreover, in times of chaos and poverty, the struggling poor often sold their wives, children, and even themselves for survival. Both the Tang Laws and the Song Compendium forbid the sale of human beings by deceitful or violent means. ${ }^{211}$ But neither prohibits human transaction, per se. And even with the laws in place, violations occurred on a regular basis. ${ }^{212}$

\subsubsection{Tangut Laws on Human Transactions}

The Laws of Heavenly Prosperity prohibits any transaction of one's own kins, for families are the likeliest to exercise dominations over their relatives.

Junior members of the family who sell their senior kins, such as grandfather, grandmother, father, mother, etc., are to be executed by sword if intention is established; accomplices are to be sentenced to imprisonment for life. ${ }^{213}$

211 Zhangsun Wuji [Tang Dynasty] et al.; Liu Junwen (ed.). Tanglü Shuyi [唐律疏議]: Commentary on the Tang Code. Beijing: Law Press, China, 1999, pp. 399-406; Dou, Yi [Song Dynasty] et al.; Xue, Meiqing (ed.). Song Xingtong [宋刑統]: Compendium of Song Laws. Beijing: Law Press of China, 1998, pp. 356-362.

212 Yu, Guilin. “Songdai Maimai Funü Xianxiang Chutan” [宋代買賣婦女現象初探]: “A Preliminary Study of the Phenomenon of Selling and Purchasing Women in the Song Dynasty" Zhongguoshi Yanjiu [中國史研究]:Journal of Chinese Historical Studies, issue 3, 2000, pp. 102-112.

213 Revised Laws of Heavenly Prosperity 1, "On Disharmony," p. 128. The 'segment' is a Tangut term for "generation"; so 'higher segment above' refers to senior members of the older generation, and 'lower segment below' are the younger generations, or junior members of the family. 
The Laws also penalise the sale of other kins,

Junior members of the family who sell their senior kins, such as their own grandparents and parents, in addition to judging their crimes, let anyone who attempts to sell kins who fall within the mourning period be hanged; let any accomplice be sentenced to 12 years in jail.

For senior members of the family accused of selling their younger kins,

who ought to perform mourning for 3 months, let him be sentenced to 12 years of imprisonment if there is intention; let the accomplice be sentenced to ten years;

who ought to perform mourning for 5 months, let him be sentenced to 10 years of imprisonment if there is intention; let the accomplice be sentenced to eight years;

who ought to perform mourning for 9 months, let him be sentenced to 8 years of imprisonment if there is intention; let the accomplice be sentenced to 6 years;

who ought to perform mourning for 1 year, let him be sentenced to 6 years if there is intention; let the accomplice be sentenced to 5 years;

who ought to perform mourning for 3 years, let him be sentenced to 5 years of imprisonment if there is intention; let the accomplice be sentenced to 4 years. ${ }^{214}$

In all the aforementioned cases of a senior member of the family selling his junior kins, if the sold person is willing to oblige, let the seller's sentence be commuted to one level below.

If a man attempts to sell his own wife, and the wife is unwilling to be sold, let the man be sentenced to six years of imprisonment. If the wife is willing, let the man be sentenced to five years, instead. If the wife, or the father, brother, and other third parties report the sale, first let the woman go whither she wishes. Then, let the one who reported be rewarded in accordance with the laws on rewarding reports on miscellaneous crimes. If the husband regrets and reports himself, let him be acquitted, and let the wife and the payment be returned. ${ }^{215}$

214 TN: The point is that, the longer the mourning period is required of the junior kin, the lower his or her status must be within the family; the lower his or her status is, the lighter the crime it is to sell him or her, hence the shorter the sentence.

215 Revised Laws of Heavenly Prosperity 6, pp. 258-259. 
However, Tangut laws do not prohibit the sale of shijun and nupu, who are treated as tradable commodities, along with farmland and houses. These semi-slaves constituted a special class within the Tangut society. The shijun is the equivalent to the buqu in the Tang Dynasty. They could have been criminals exiled to the frontiers, or captured in the wars, spared their lives, and turned into serfs and servants by their conquerors. ${ }^{216}$ The Laws of Heavenly Prosperity state that,

If our party has captured certain individuals by force, and enslaved them as shijun and nupu; whereas their family kins and relatives cross over and surrender to the Fan state; thereupon, if it is determined that they are indeed the kinsmen of the ones captured by force, let them be voluntarily reunited ...217

Some shijun might also have been bankrupt peasants and serfs.

Owners of shijun and nupu are referred to in the Laws of Heavenly Prosperity as 彻後 [yu dzju], which literally translate to "head supervisers," or simply owners. It is an extraordinarily capacious term in the Laws of Heavenly Prosperity. In Western Xia, there are 'head supervisers' in almost every aspect of society, let alone branch of government: in the offices, the military, and even in hierarchical monastic establishments. A large number of references to the head supervisers' in the Laws of Heavenly Prosperity are, in fact, those who supervise their own servants, serfs, and semi-slaves. In other words, these 'head supervisers' are, simply put, de facto slave owners who exercise special power over the individuals in their dominion. The social status of the owned persons is such that they cannot make decisions over their private affairs without the intervention of the masters. The Laws of Heavenly Prosperity is clear that,

If the shijun in possession do not consult their head supervisers, and do not obtain the necessary documents, they are not allowed to sell their own children, daughters-in-law, aunts, and sisters to others out of their own will. If they thus violate the laws, let them be indicted of the crime that is one level above theft of cash and property. If the buyers are aware of the illegality of the trade, and yet proceed to the transaction, let them be tried as accomplices; if they are not aware, let them not be indicted. If

216 TN: As in the case of Roman slaves. See Shi, Jinbo and Li, Hansong. Tangut Language and Manuscripts: An Introduction. Leiden: Brill, 2020, pp. 445, 472-473.

217 Revised Laws of Heavenly Prosperity 7 , "To Resettle Those Who Cross over to our Side and Surrender," pp. 273-274. 
the seller does not initiate the discussion on the sale, and yet the buyer is makes explicit his intention to purchase, and raises the price to obtain the purchase, then let the buyer be tried for the same crime as the seller. If the sold women bear children, let all of them be returned to the lawful owner. As for the payment already made, let the seller cover it if he is able to; if he isn't, then let the seller be penalised for the sum. Let the intermediary agents who go between the seller and the buyer be sentenced to 6 months of imprisonment. Let them not be indicted, if they are unaware of the illegal nature of the transaction.

If the shijun in possession do not consult their head supervisers, and do not obtain the necessary documents, they are not permitted to marry their daughters, sisters, aunts, et al. to others. Let those who violate this law be sentenced to four years of imprisonment. The children born out of these wedlocks should be returned to the lawful owners. As for any payment maid for the marriage, let the shijun who arranged for the marriage cover it if he is able; if he is not, let the owner bear the costs.

If the aforementioned shijun have consulted their head supervisers, who are willing to grant the legal papers, then let them be permitted to sell or marry their children, daughters-in-law, aunts, and sisters to others. ${ }^{218}$

In other words, not only could the masters sell their shijun, but the shijun also have the right to sell the women in his own household, provided that the obtains consent from his master. It is also found in the Laws of Heavenly Prosperity that,

If the daughters, sons, wives, daughters-in-law, shijun, and nupu enter into a verbal quarrel, and which escalates into a physical altercation with the parents, husband, and supervisers, in the midst of which the former are accidentally wounded in the eyes, ears, and noses, injured in their hands and feet, or have their muscles and bones broken, let the culprit be fined a horse if he has official status, or suffer 13 lashes if he is a commoner. If the person is not wounded but dead, let the individual concerned be sentenced to 6 months of imprisonment. If the injury is afflicted by a sword or knife upon the eyes, ears, noses, feet, hands, and muscles, to the

218 Revised Laws of Heavenly Prosperity 12, p. 417. 
point that it causes the death of the person, then let the case be judged in accordance with the laws as follows. ${ }^{219}$

The Laws of Heavenly Prosperity enumerates several severe crimes in parallel, "the murder of great (great) grandparents, grandparents, parents, and father's concubines; the murder of parents-in-law by the daughter-in-law; the murder of husband by wife; the murder of the head superviser by the shijun ..."220 It suggests that the Tanguts saw the relationship between the master and the shijun or nири as equivalent to that between parents and children, husband and wife.

In the three Tangut contracts of human transaction, all the persons to be sold are either shijun or nupu. Near the end of the third contract, there is an additional line written in Chinese, which makes clear that the "the private persons are a household of four" which "cost 100 guan." The "private men" refer to the persons held in private possession. The same expression in found in the Laws of Heavenly Prosperity, for instance:

The higher and lower officials are not permitted to demand governmentowned persons to be their privately-owned persons. Nor are they allowed to turn those who are indicted for severe crimes, exempted from capital punishment, and instead commuted into an exile in the frontiers as persons bound to a farmland or a pasture, into their own privately-owned persons. $^{221}$

The so-called government-owned persons are quasi-'palace slaves,' legally owned by the court or by a government office. They are also deprived of personal freedom, but they differ from quasi-'household slaves,' persons owned by private individuals and their families. The laws demand that private ownership not interfere and conflict with government ownership. There are also criminals who end up exiled to the remote areas of the empire, after their death or life sentence is communited, and work as indentured labourers on farms or pastures. These men, too, are not eligible to be turned into 'private men.' Tangut masters also counted on the laws to safeguard their rights, should their 'private men' seek to escape. ${ }^{222}$

Three years after the Renzong Emperor passed away, in the third year of Tianqing (1196), Empress Luo released the 'private men' at large or to the

219 Revised Laws of Heavenly Prosperity 8, pp. 296-297.

220 Revised Laws of Heavenly Prosperity 13, p. 447.

221 Revised Laws of Heavenly Prosperity 6, pp. 254-255.

222 Revised Laws of Heavenly Prosperity 7, "On the Defection and Escape of the Fan," pp. $275^{-281 .}$ 
government, released prisoners $5^{2}$ times, assisted the poor 65 times, released 70,790 sheep, and granted a universal amnesty. ${ }^{223}$

\subsubsection{Price Analysis}

The primary purpose of human transactions is to optimise labour value. Unsurprisingly, younger and stronger men are worth more than the elderly, and women in their fertile ages are especially valuable, since they are able to give birth to new labour. In the first contract, 6 persons are sold for $45^{\circ}$ guan, at an average price of 75 guan in iron coins. Each of the 4 younger ones may have been worth about 8 o guan. In the second contract, 2 persons are sold for $5^{\circ}$ dan of coarse grains. We have inferred from Khara-Khoto grain accounts that the price of coarse grains is at approximately 150-200 mace per dou. The cash value of 5 o dan of coarse grains falls in the $75^{-100}$ guan range, which gives the average price as $35^{-5}$ o guan. In the third contract, 4 persons are sold for 100 guan, at the average of 25 guan.

All three contracts are found in Khara-Khoto. They are, above all, representative of human sale and purchase in that area. Nonetheless, we see a considerable discrepancy in the prices across the three contracts. Perhaps the timing of the contract is an important explanatory variable.

There is an error in the dating of the first contract. But whether it is signed in the fifteenth year of Qianyou (1184) or Bingchen, the third year of Tianqing (1196, allegedly, the 27th year of Qianyou), this contract is the earliest of all three documents. The second contract is dated to the Yiwei, Sixth year of Tianqing (1199), 15 years after the Jiachen year of Qianyou. The third contract is written in the Gengwu, First Year of Huangjian (1210) near the very end of the Western Xia Dynasty, and another 11 years apart from the second contract.

CHART 18 Statistics on human sales

\begin{tabular}{|c|c|c|c|c|}
\hline Register & Date & $\begin{array}{l}\text { Persons } \\
\text { sold }\end{array}$ & Total price & $\begin{array}{l}\text { Average price } \\
\text { per person }\end{array}$ \\
\hline Инв. No. 15949-29 & $\begin{array}{l}\text { Jiachen, 27th year of } \\
\text { Qianyou }\end{array}$ & 6 & $\begin{array}{l}450 \text { guan } \\
\text { iron coins }\end{array}$ & 75 guan + \\
\hline Инв. №. 4597 & $\begin{array}{l}\text { Jiwei, 6th year of } \\
\text { Tianqing (1199) }\end{array}$ & 2 & $\begin{array}{l}5^{\text {o dan of }} \\
\text { coarse grains }\end{array}$ & $35^{-5}$ o guan \\
\hline Инв. №. $79 \circ 3$ & $\begin{array}{l}\text { Gengwu, 1st year of } \\
\text { Huangjian }(1210)\end{array}$ & 4 & $\begin{array}{l}100 \text { guan } \\
\text { coins }\end{array}$ & 25 guan \\
\hline
\end{tabular}

223 Russian Collection of Khara-Khoto Manuscripts, vol. 2, TK98, pp. 372-373. 
The chart above shows that over the progress of time, the later it is, the lower the price is. Usually, the more stable a society is, the higher the labour cost, and vice versa. Under the reign of Emperor Renzong, Western Xia in the Qianyou era witnessed impressive cultural prosperity, considerable economic development, and relative social stability. After Emperor Renzong passed away, Huanzong succeeded to the throne. Over time, Tangut power went downhill, but managed the decline with some ability and stability. In the final 22 years, however, external threats compounded the anxieties at home. The Tangut society suffered a stream of upheavals, whereby the lived experiences of populations in the empire quickly deteriorated. Under these circumstances, it is no surprise that the market price in human transactions should have fallen. As a result, we see the trend of tumbling prices over time, as reflected in the three contracts.

Another detail of interest and import is the use of iron coins in the first contract: $45 \circ$ guan in iron coins. Whether it is in the Central Plains or in Western Xia, iron coins are worth less than copper coins. Western Xia always suffered a scarcity of copper. Worse still, the Jurchens placed an embargo on copper, forcing the Tanguts to adopt Song coins. In fact, the Song Dynasty began to co-circulate iron and copper coins much earlier. To avoid the flow of copper into Western Xia, the Song Dynasty minted iron coins in its border zones in Shaanxi and Hedong. The Tanguts, on their part, sought to trade their iron coins en masse for the Song copper coins, a venture that greatly troubled the Zhezong Emperor of Song,

The Shaan region is the border zone where copper and iron coins are exchanged. When the westerners visit, they must exchange for copper coins in order to go further east. To the point where today, in the private market, as much as 1700 iron coins are exchanged for 1000 copper coins. As a result, the iron coin devalues, whilst the copper coin appreciates even more. All the commodity prices are inflated. This causes the gravest harm..$^{224}$

The 'westerners' are of course the travellers and merchants from Western Xia. The Tanguts' massive currency exchange devalues the Song iron coins, and thus affects the commodity prices in the Song market. Policy-makers in the Song court enacted counter-measures to solve this problem. They enacted legislations that set a quota on how much a Tangut is allowed to exchange for,

224 Extended Zizhi Tongjian [續資治通鑒長編] Book 457, Sixth Year of Yuanyou in Zhezong Emperor's Reign (1091), fourth month, Jiawu. 
at the rate of 2/10 of their tax, with a cap of 5000 copper coins, at the maximum. In addition, those who exchange iron for copper coins at relay stations in Shaanzhou and Xiashi, have no choice but to exchange 1000 iron coins for 800 copper coins.

The use of iron versus copper coins within Western Xia varies across its geography. The Laws of Heavenly Prosperity state that,

The many are prohibited from transporting the black iron coins from the domain of the Southern Realm etc. to the Imperial Capital, or the copper coins in the Imperial Capital to the domain of the Southern Realm etc. Any violation of law results in two years of imprisonment, regardless of the amount of cash involved. Anyone who reports such misconduct is rewarded in accordance with the laws on rewarding reporters of miscellaneous crimes. ${ }^{225}$

We know from the inscription of the Liangzhou stele that the administrative region of the "Southern Realm" corresponds to the Chinese geographical term, Youxiang (右廂). ${ }^{226}$ The region concerned is the larger area of Liangzhou. In fact, iron coins circulated widely across Western Xia. "Southern Realm, etc." encompasses almost the entire northwestern region of the Tangut Empire, including, of course, Khara-Khoto. But iron coins appear in only one of the three contracts of human transactions. The third contract does not specify what coins are used. But given the context, it is more likely to be iron, rather than copper. But even if it isn't iron, we know for certain that at the conversion rate of 4:5, the average price in the first contract remains the highest.

The transaction of human beings is not rare in history. However, original and authentic contracts of human transactions are as rare and precious as the feather of phoenix and the horns of unicorns. There are three Dunhuang contracts of human transactions, all from the 1oth century: in the Bingzi year of 916, Awu sells a 7-year-old son for 30 dan; in the 9th year of Zhenming (923), Cao Liuzhu sells a 10-year-old son for ?.5 pi of raw silk; in the 2nd year of Chunhua (991), a 28-year-old girl is sold for $3 \mathrm{pi}$ of raw silk and 2 pi of processed silk. ${ }^{227} \mathrm{We}$ could peform a simple and quick comparative analysis of the Dunhuang and Khara-Khoto contracts.

225 Revised Laws of Heavenly Prosperity 7, p. 287.

226 Shi, Jinbo. Xixia Fojiao Shilüe [西夏佛教史略]: A Brief History of Tangut Buddhism, pp. 249, 253 .

227 Dunhuang Economic Documents II, pp. 47-49. 
In the first Khara-Khoto contract, the average price is 75 guan, or $37-50$ dan, given the price of coarse grains at about 150-200 mace per dou; In the second Khara-Khoto contract, the average price is 25 dan; in the third contract, the average price ranges between 13 and 17 dan. In the first Dunhuang contract, the price is 30 dan; the second contract is incomplete and may therefore be set aside for the time being; in the third contract, the girl is sold for 5 pi of raw and processed silk. Assuming that silk price in Dunhuang at the time comes close to the standard silk price in Western Xia, that is, 16-21 guan per pi, or 8-10 dan per $p i$, then the girl was sold for about 40-50 dan of coarse grains (again, assuming that the price difference between raw and processed silk could be evened out). Despite the lapse of two to three centuries, and the variations of conditions and contexts across different cases, we could see that when it comes to the grain-to-price ratio in human sales, there is a remarkable degree of consistency.

\subsubsection{Social Issues in Western Xia, as Reflected in Human Transactions}

The land-owning and pasture-owning Tangut aristocracy, with the royal house at its core, is the cetnre of power in the feudal society of Western Xia. The vast majority of the Xixia population consisted of ordinary peasants, herdsmen, and craftsmen. However, there are still classes of slave-like men and women, such as the shijun and nupu, at the very base of the social order. They suffered serious economic exploitation, without basic freedoms and human dignity, as they were traded as commodities. And yet, such a cruel conduct was legitimated in the imperial code of laws.

To be sure, there existed a more conspicuous vestigial class of slaves in the early history of the Dangxiang Tanguts. At the time, there were four sources of enslavement: those captured in war, purchased in sale, unable to pay debt, and punished for crimes. ${ }^{228}$ The History of Song notes that "in the Gengyin year, there is an imperial interdict against selling off live human beings in the many prefectures along the Shaanxi frontier"; "In the autumn, the seventh month of the Yihai year, there is an imperial command issued to the many prefectures along the Shaanxi frontier, that their governments should random any famine refugees who fled to neighbouring tribes." 229

Amongst all hitherto discovered Tangut contracts, the vast majority are records of grain loan. Very few are purchase and sell contracts. We have mentioned that there are only 12 land sale contracts. The fact that 3 contracts of

228 Wu, Tianchi. Xixia Shigao [西夏史稿]. Beijing: Commercial Press, 2010, pp. 136-137.

229 History of Song, Bk. 2. Taizong Ji'er [太宗紀二]. 
human transaction have survived to this day suggests that the selling and purchasing of human beings was anything but exceptions in Western Xia.

\section{$4 \quad$ Lease Contracts}

Renting and leasing is a common form of economic activity in Western Xia. The standard story in most of ancient Chinese history is that the state owns the land, whereto all peasants paid their taxes. Another form of land-use is where the major land-owners lease out their land to those with little or no land to farm. Tangut lease contracts belong to the latter case.

\subsection{Land Lease}

There is a large number of farmland lease contracts in the corpus of Khara-Khoto social documents. In the Инв. No. 5124 scroll of contracts, there are 8 Tangut land lease contracts, which are of vital importance to anyone who wishes to study the social lives and agricultural economy of this area, during this time.

There are 23 pieces of contracts in that long scroll mentioned above. Apart from the contracts of land and livestock sale, and accounts of livestock and grain loans, there are an additional 8 contracts of land lease. ${ }^{230}$ In the following pages, let me present a translation, interpretation, and survey of these documents.

\subsubsection{Translation and Interpretation of Land Lease Contracts}

Khara-Khoto land lease contracts are scattered across long scrolls of other contracts, oftentimes attached to contracts of land sales. So, land is sometimes sold and immediately leased out. Like the land sale contracts, land lease documents are usually written in nearly inscrutable cursive styles. In the next few pages, I translate a series of Tangut contracts of land lease at fixed prices.

230 Russian Collection of Khara-Khoto Manuscripts, vol. 14, pp. 13-22. 


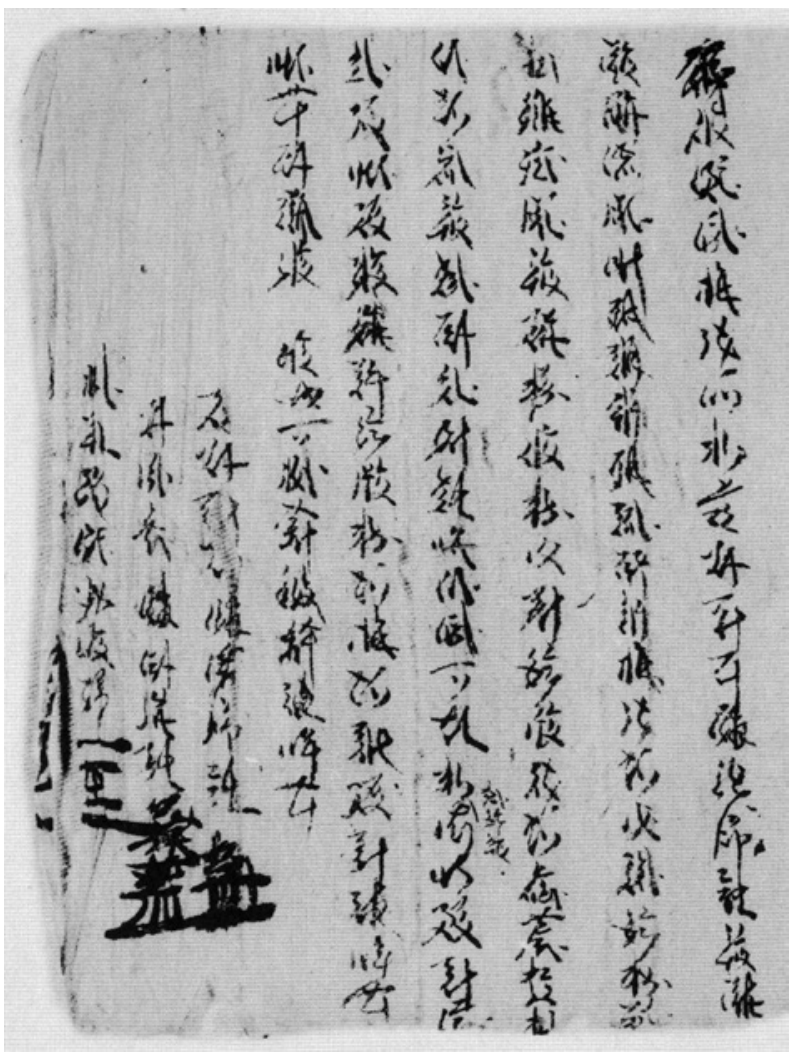

FIGURE 179

Инв. No. 5124-2(2): 24th day of 1st month in Yin year of Tianqing (1194) contract of land lease at fixed price by 绿㳇恲颓

1. The manuscript Инв. No. 5124-2(2) is a Contract of Land Lease at Fixed Price dated to the 24th day of the 1st month in the Yin Year of Tianqing (1194), which belongs to Su 'The Old House.' It features 9 lines of cursive Tangut in the long scroll of contracts, from the date to the stamp and signature. ${ }^{231}$

Translation:

On the 24th day of the 1st month in the Yin Year, Contactor Su 'the old house' et al. presently

Lease a patch of land enough to sow 20 dan of seeds, in the Left Canal near the end of the Canal belonging to the Pudu Temple,

231 Russian Collection of Khara-Khoto Manuscripts, vol. 14, is a scroll of contracts. The previous contract is dated to the 酸效拜很 [ywor ljwu le kjiw] (Yin Year of Tianqing). The contract should have been signed in the Jiayin Year of Tianqing (1194). 
Where all the cottages and yards are included; the lease is for one year at a fixed price, ${ }^{232}$ rent $^{233}$ is 10 dan 5 dou of wheat and

5 dan of coarse grains, which is agreed upon. Payment is due by the 1st day of the 9 th month.

Past the deadline, for each 1 dan of rent, let the payment be 2 dan, instead. Heart truly willing.

The party that reneges on the agreement is penalised by 1 liang of gold according to the laws. Heart truly willing.

Contract Party: Su 'the old house' (隠父拼絡) (stamp)

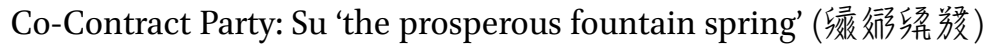
(stamp)

Witness

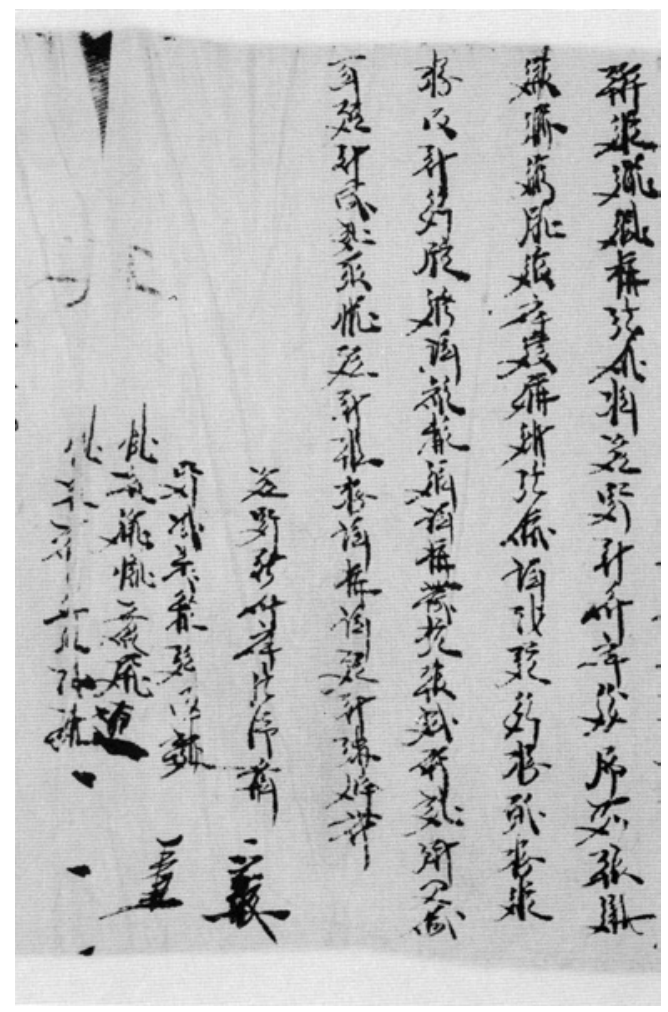

FIGURE 180

Инв. No. 5124-3(3): 29th day of 1st month in Yin year of Tianqing (1194) contract of lease at fixed price by Liang Laofangcheng et al.

232 The Tangut expression is 韧, 反 [-ja phio] (already leased out [at the fixed price]). The first character is a verbal prefix signifying the state of completion of a particular action. The second character is a loan word from the Chinese 包, which means to rent a patch of land [at a fixed price] to farm.

233 The Tangut expression is 旼哜 [ [ jii-. mej], rent paid by the tenants to the landlord. 
2. The manuscript Инв. No. 5124-3(3) is a contract of land lease at fixed price dated to the 29th Day of 1st Month in the Yin Year (1194), by 篗父拼荊 [ljow da kia śji-j] et al. It consists of 8 lines in the long scroll of contracts, from the date to the stamps and signatures. ${ }^{234}$

Translation:

On the 29th Day of 1st Month in the Yin Year, the Contract Party 倠父拼 荊 [ljow da kia śji-j] et al., presently

Lease a patch of land for one year at a fixed price, where 15 dan of seeds can be sowed, owned by 䋖㺼姘 [ljow lja mja] at the Pudu Temple. ${ }^{235}$

Both parties agree to set the rent at 6 dan of coarse grains and 4 dan 2 dou of wheat, due by the 8 th month,

1st day; ${ }^{236}$ past that date, double each dan in debt. Their own hearts are willing.

Contract Party: Liang 倠父拼荊 [ljow da kia śji-j] (stamp)

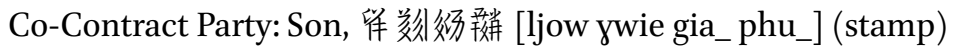

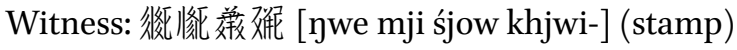

Witness: ???? (stamp)

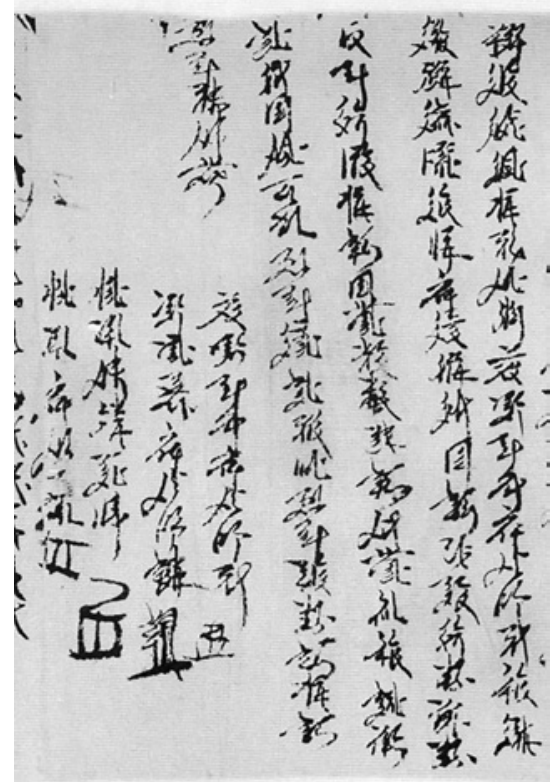

FIGURE 181

Инв. No. 5124-3(5): 29th day of 1st month in Yin year of Tianqing (1194) contract of land lease by 盗父恲敦 et al.

234 Russian Collection of Khara-Khoto Manuscripts, vol. 14, p. 15.

235 The leased land could be the same patch of land sold by 终恲骰 [ljow da kia jiw], fit to sow 15 dan of seeds, on the same day.

236 There is a missing character 妙 [nji-_] (day) in the original text. 
3. The manuscript Инв. No. 5124-3 (5) is a contract of land lease dated to the

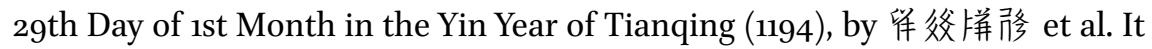
consists of 8 lines of Tangut in the cursive script in the long scroll of contracts, from the date to the stamps and signatures. ${ }^{237}$

Translation:

On the 29th Day of 1st Month in the Yin Year, Contract Party 篗条栟胗 [ljow da kia jiw] et al., presently

Lease a patch of land at a fixed price, where 8 dan of seeds are sowed, from 倠徒姘 [ljow lja mja] at the Pudu Temple,

The rent being 2 dan 8 dou of wheat and 3 dan 6 dou of coarse grains, hereupon agreed,

Due by the 1st day of the 8th month. Overdue payment doubles.

Own heart willing.

Contract Party: 倠父栟胗 [ljow da kia jiw] (stamp)

Co-Contract Party: 篗多冬拼龵 [ljow da kia phu_] (stamp)

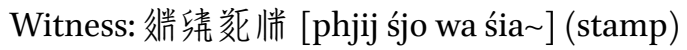

Witness: 徉父栟? [ljow da kia ?] (stamp)

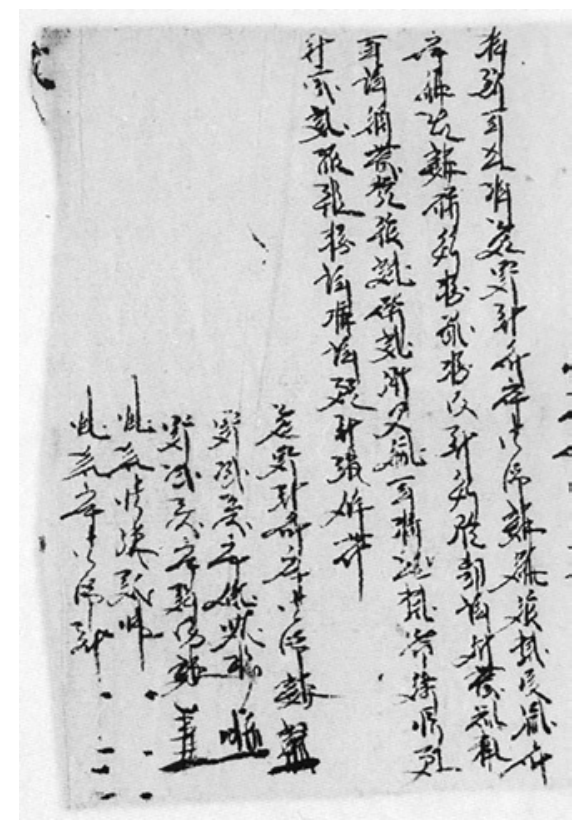

FIGURE 182

Инв. No. 5124-3(8): 1st day of 2nd month in Yin year of Tianqing (1194) contract of land

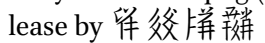

237 Russian Collection of Khara-Khoto Manuscripts, vol. 14, p. 16. 
4. The manuscript Инв. No. 5124-3(8) is a contract of land lease dated to the 1st day of the 2nd month in the Yin Year of Tianqing (1194). The land is leased to 傕缁样彩 [ljow da kia phu_]. It consists of 9 lines of Tangut cursive in the long scroll of contracts, from the indication of date "on the same day, the first"which would set the date to the same as the previous contract: first day of the second month in the Yin Year-to the stamps and signatures of the parties involved in the lease. ${ }^{238}$

Translation:

On the same day, 239 筹父拼鞾 [ljow da kia phu_] who sets up this contract, presently from a grain-selling agent at the Temple,

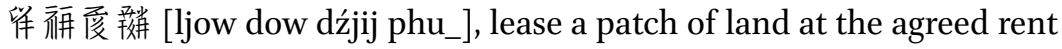
of 3 dan 6 dou of coarse grains and

1 dan 4 dou of wheat, due by the 1st day of the 8th month.

Overdue payment doubles. Heart willing.

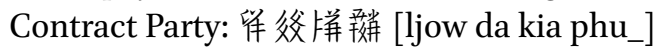

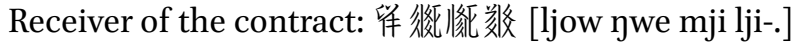

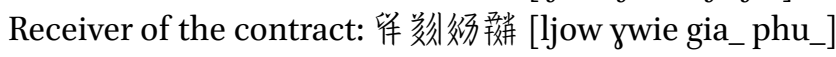

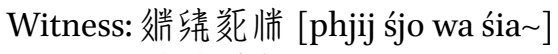

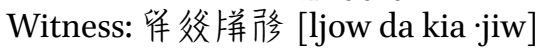

238 Russian Collection of Khara-Khoto Manuscripts, vol. 14, p. 18.

239 The previous contract is dated to the 1st day of the 2nd month in the Yin Year 留数绍務 [ljow ywie gia_.jiw], a land sale contract. This contract is signed on the same day. 


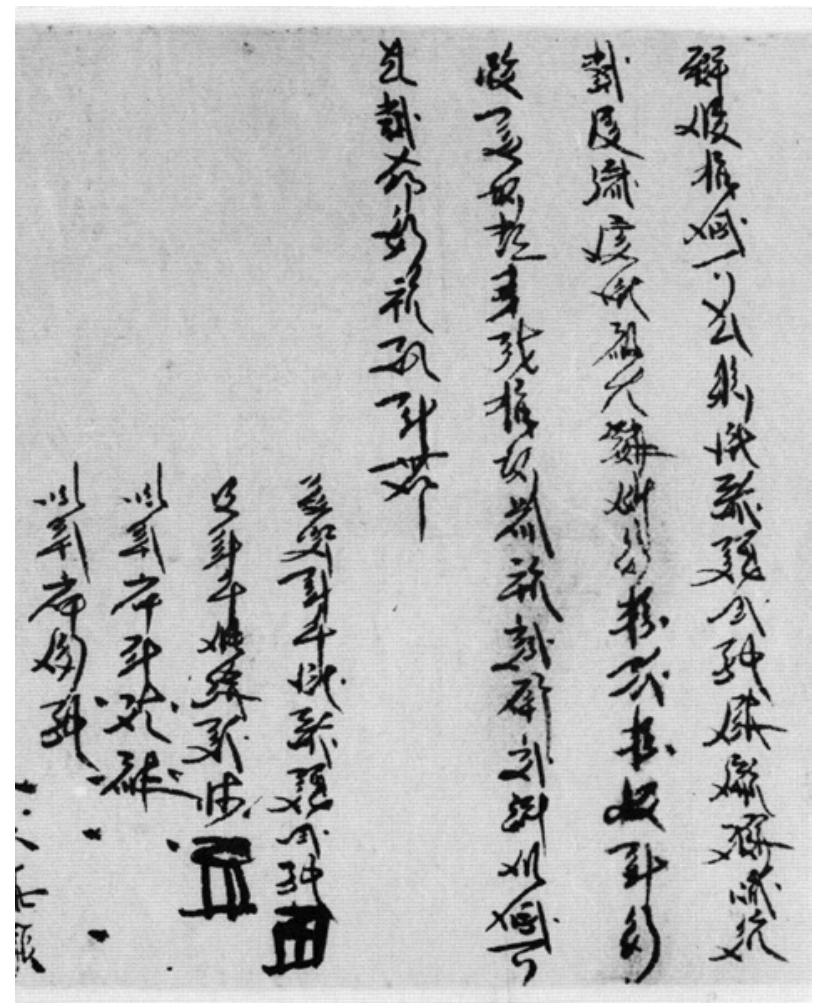

FIGURE 183

Инв. No. 5124-3(2): 1st day of 2nd month in Yin year of Tianqing (1194) contract of land lease at

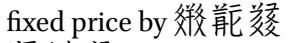
效行聠

5. The manuscript Инв. No. 5124-3(2) is a Contract of Land Lease at Fixed Price, by a man named 稀徬 [mjadzjwi-], dated to the 1st day of the 2nd month in the Yin Year of Tianqing (1194). It is recorded in 8 lines of Tangut cursive in the long scroll of contracts, from the indication of date to the stamps and signatures, following the standard format. ${ }^{240}$

Adapted Translation:

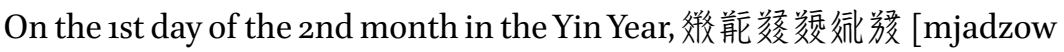
pji.phə tśhja wejr] presently from

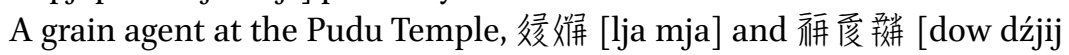
phu_], lease a patch of land they own at a fixed price; upon mutual agreement, the rent is set

At 7 dan of wheat and 12 dan of grains, due by the 1st day of the 9 th month. Willing. 


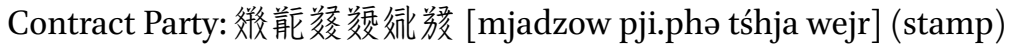

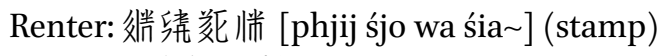

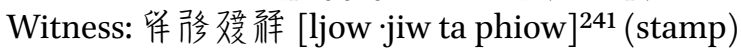

Witness: 留烈俨 [ljow ne_w wejr] (stamp)

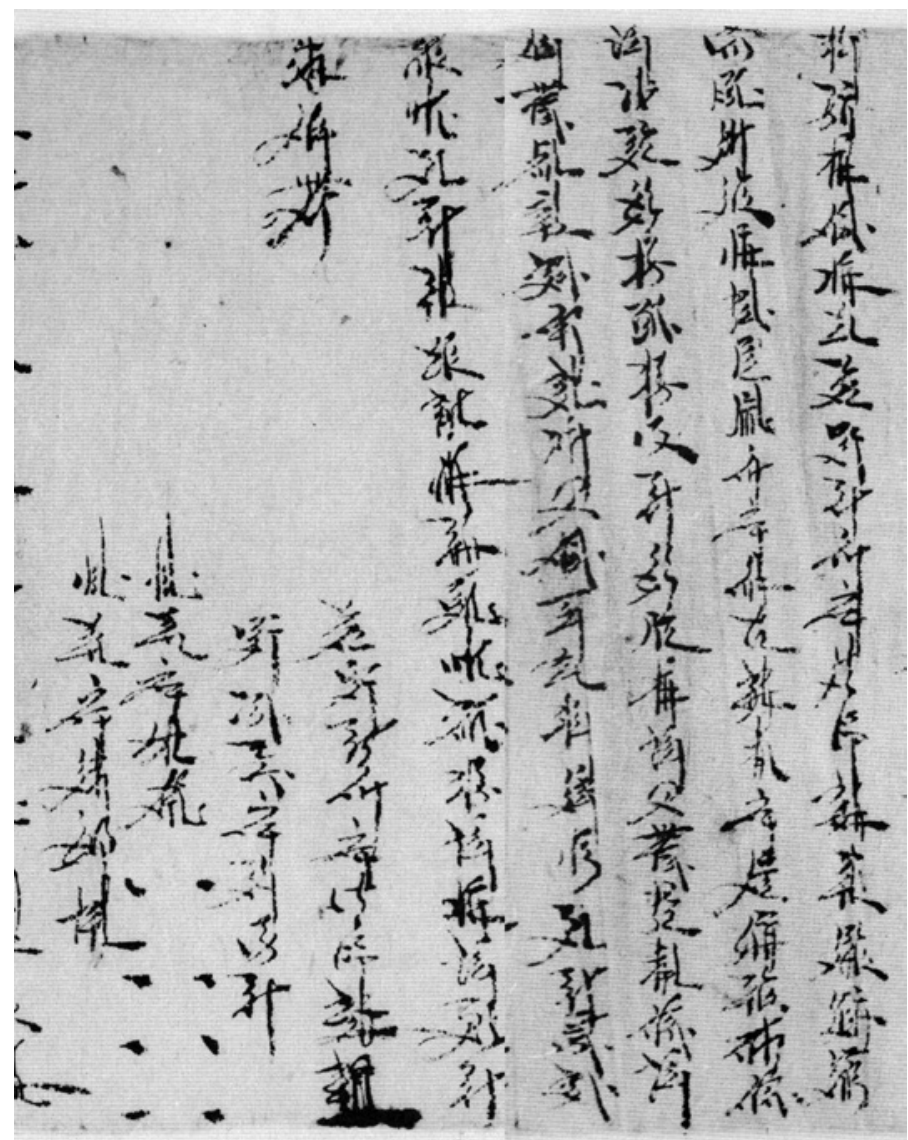

FIGURE 184 Инв. No. 5124-4(1, 2): 2nd day of 2nd month in Yin year of Tianqing (1194) contract of land lease at fixed price by

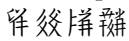

6. The manuscript Инв. No. 5124-4 $(1,2)$ is a Contract of Land Lease at Fixed Price dated to the 2nd day of the 2nd month in the Yin Year of Tianqing (1194).

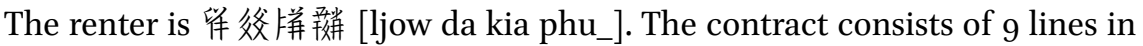
the Tangut cursive, from the date to the stamps and signatures. ${ }^{242}$

241 TN: lit. the white dog in the You year.

242 Russian Collection of Khara-Khoto Manuscripts, vol. 14, pp. 18, 19. 


\section{Translation:}

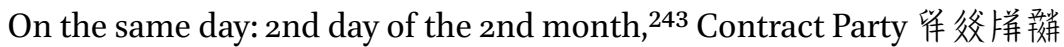
[ljow da kia phu_] et al. from the

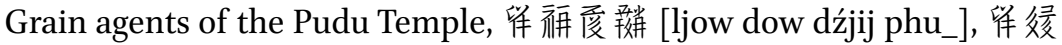
偝层 [ljow lja mja] et al., lease

A patch of land at fixed price, where 5 dan of seeds are sowed, at the agreed rent of 2 dan 8 dou of wheat and 5 dan

4 dou of coarse grains, due by the 1st day of the 8th month,

Overdue payment is not only prosecuted by law but should also double.

Heart willing.

Contract Party: 留父拼形茟 [ljow da kia phu_] (stamp)

Receiver of Contract: 华刻须弦 [ljow ywie gia_-jiw] (stamp)

Witness: 傕榎前 [ljow wejr śjow] (stamp)

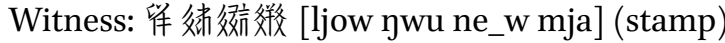

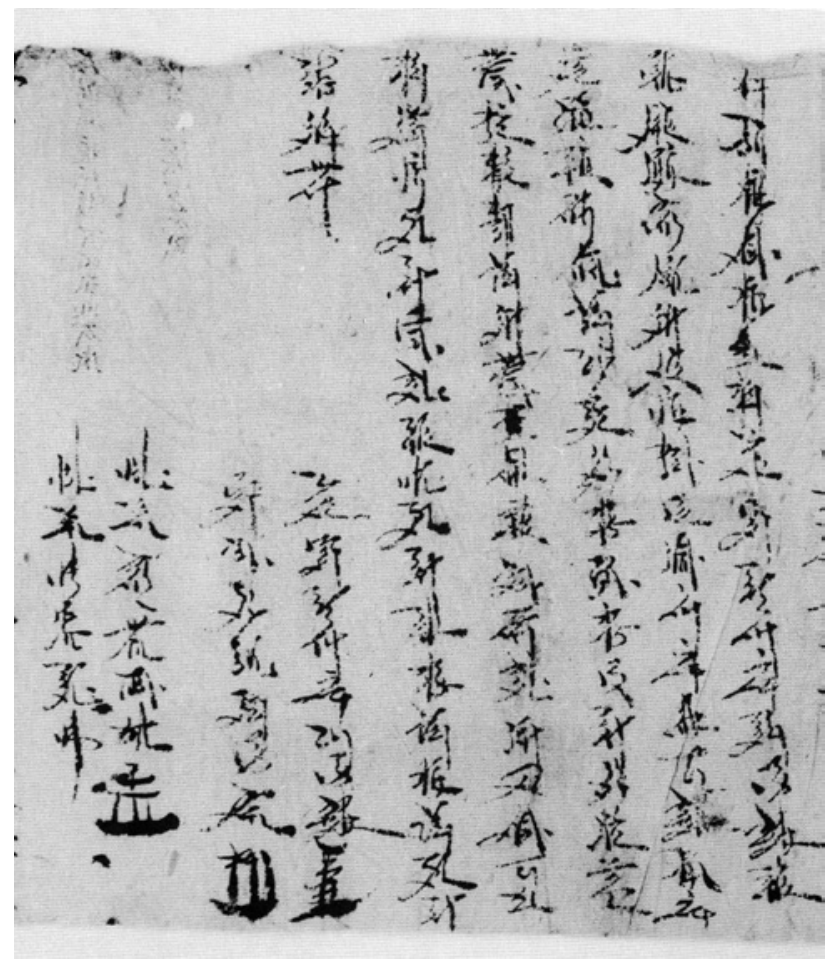

FIGURE 185

Инв. No. 5124-4(3): 2nd day of 2nd month in Yin year of Tianqing (1194) contract of land lease at fixed price by

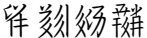

243 Usually, "on the same day" refers back to the same full date, month, and year in the previous contract. There is no need to repeat any bits of information. Still, this contract repeats the precise date, 2nd day of the 2nd month. 
7. The manuscript Инв. No. 5124-4(3) is a Contract of Land Lease at Fixed Price dated to the 2nd day of the 2nd month in the Yin Year of Tianqing (1194). The lease, recorded in 9 lines of cursive Tangut in the long scroll, is taken by 㸺䊽

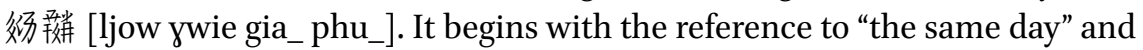
ends with the stamps and signatures. ${ }^{244}$

Translation:

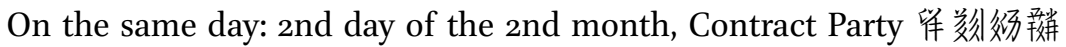
[ljow ywie gia_phu_] et al.,

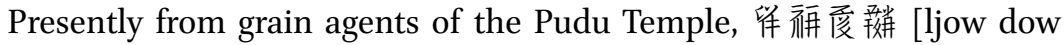
dźjij phu_] and 㸷 [ljow]

啳娧 [lja mja] lease a patch of land at fixed price, where 5 dan of seeds are sowed, the rent

Agreed upon being 7 dou of wheat and 3 dan 6 dou of coarse grains. Due by the ist day of the 8th month

Overday payment will double.

Own heart willing.

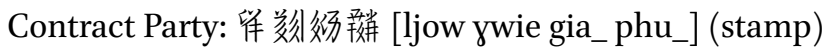

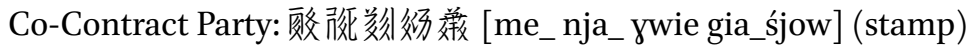

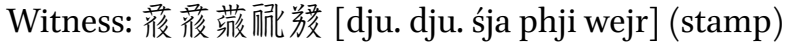

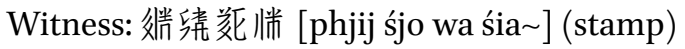

244 Russian Collection of Khara-Khoto Manuscripts, vol. 14, pp. 18, 19. 


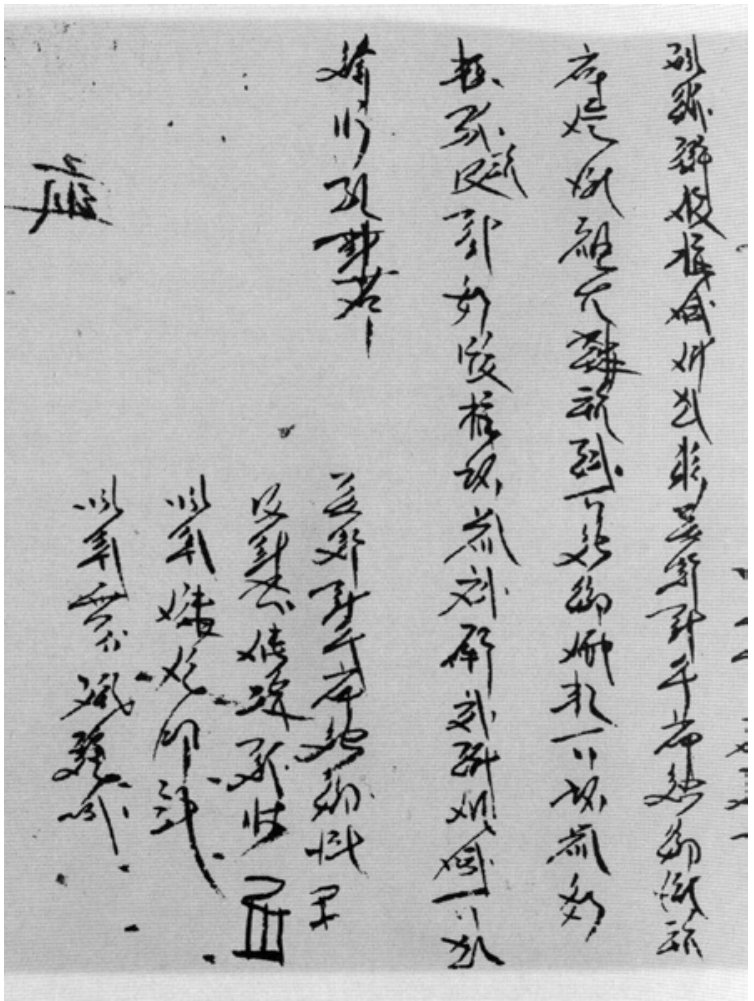

FIGURE 186

Инв. No. 5124-4(7): 6th day of 2 nd month, Yin year of Tianqing (1194) contract of land lease at fixed price by

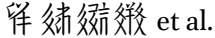

8. The manuscript Инв. No. 5124-4(7) is a Contract of Land Lease at Fixed Price dated to the 6 th day of the 2nd month in the Yin Year of Tianqing (1194), recorded in 8 lines of cursive Tangut in the long scroll, from the reference to "the same day" to the stamps and signatures. ${ }^{245}$

Translation:

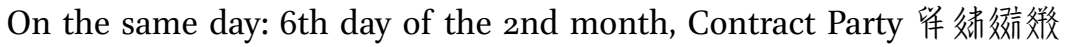
[ljow ywu ne_w mja] et al.,

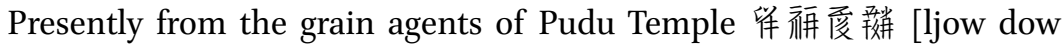
dźjij phu_] and 粦 [ljow]

徍栟 [lja mja], lease a patch of land at a fixed price where 5 dan of seeds are sowed. The rent is 7

dou of wheat and 3 dan 6 dou of coarse grains, hereupon agreed, due by the ist day of the 8 th month.

245 Russian Collection of Khara-Khoto Manuscripts, vol. 14, p. 21. 
Overdue payment should double.

Own heart willing.

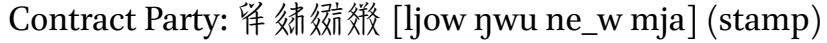

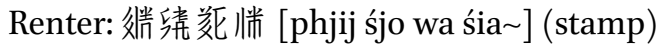

Witness: 婹父拼绫 [sji da kia zji] (finger segment printed)

Witness: 橆鹳效徽 [khjiw khjwi- phə bie_j] (finger segment printed)

4.1.2 The Format and Content of Tangut Land Lease Contracts

4.1.2.1 Contract of Land Lease at Fixed Price

The land lease contracts presented and translated above appear to share the same general format as other types of Tangut contracts. Each document begins at the top of the page, without indentation, with the date and the name of the principal Contract Party - the party taking the lease. This is followed by the name of the landowner, the size of the land to be leased, the precise amount of rent, the date by which the rents are due, as well as the terms of penalty for overdue payment. Finally, the contract ends with the stamps and signatures of the Contract Party, co-contract(s) and the witness(es).

At least within the compass of this long scroll of contracts, the Tangut term for the act of 'leasing' or 'renting' is the verb 帊 [phio], most probably a loan word from the Chinese 包 [pæw] (to reserve and lease at a fixed price). It is likely that the full sense of 'lease at fixed price' did not exist in the earlier Dangxiang language, until the Tanguts branched out from pasturing to farming, and adopted the practice of tenancy. In the contracts, there is usually a 'prefix of completion' before the verbal character 帊, which signals that the act of leasing is completed. ${ }^{246}$

It often happens that a land lease contract follows immediately a land sale contract, with the same patch of land sold and rented on the same day. Therefore, the lease contract usually simplifies its dating, or refers to the same date, month, or year as the previous contract in the scroll, e.g. "Yin Year ..." Here, the Year of Yin refers in fact to the Jiayin Year of Heavenly Celebration (1194 AD). After the year comes the precise date, e.g. "first month, twenty-fourth day." But again, a contract may simply refer to "the same day" for the sake of brevity.

The main "Contract Party," or "the one who makes the contract" here refers

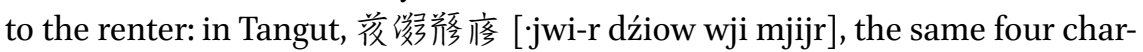
acters as in other contracts.

246 TN: Shi, Jinbo; Li, Hansong. Tangut Language and Manuscripts. Leiden: Brill, 2020, pp. $35^{6-393 .}$ 
Tangut contracts are rarely signed in two copies, each held by one party. Rather, a single copy of the contract remains in the possession of the more dominant party (the property-owner, employer, etc.). Land-lease contracts are also 'unilateral' in this particular sense. The contract is drafted in the voice of the renter-the party which proposes and initiates this legal transaction. The one who holds the contract in possession, however, is the land-owner. The fact that the land-owner is not required to sign or stamp on the contract shows his superior position-rights, advantages, and privileges—in this economic relationship. Due to his economic weakness and vulnerability, the renter is the party constrained by the terms of the contract to fulfil his duties. Therefore, these land lease contracts may be classified as 'contracts of partial obligation.'

\subsubsection{Time and Renter}

As mentioned before, the same agents purchase a patch of land and least it out almost immediately. Therefore, these eight land lease contracts share roughly the same dates as the preceding land sale contracts, in the first or second months of that year.

Note that these two months are right in the middle of the hard times in between two autumn harvests. During this interim time, peasants almost always resort to taking loans or sell properties in exchange for foodstuff. It is not enough to manage to feed the family, for they must also start farming now in expectation of a harvest in the autumn. As soon as they lease out a piece of farmland, they have to prepare for tilting and sowing.

There are exactly 8 land sale contracts and another 8 land lease contracts. A quick glance at this scroll is enough to learn the story behind the scenes:

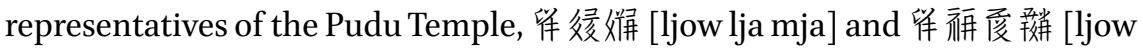
dow dźjij phu_], purchased land from impoverished families and immediately lease them out to landless peasants. There is no doubt that the Pudu monastery became a monopolistic land-owner. Exploitative temples do not buy land for direct use, but rather to lease out to peasants who either own little or no land, in exchange for rent.

\subsubsection{Land Lease and Land Sale Contracts}

Within the long scroll, it appears that land lease contracts are simpler than land sale contracts. The description of the land leased is less detailed than of the land sold. The precise location of the four bounds are not mentioned here, as in land sale contracts. Sometimes, even the names and identities of the agents involved are abbreviated or outright omitted in the lease contracts. Likewise, financial guarantee is offered in simpler terms than when a sale is involved. In general, fewer signatories are identified on a lease contract. In most cases, 
only one co-Contract Party suffices, and not as many witnesses are required as in a sale. In fact, a typical land sale contract is almost twice the length of the lease contract, concerning the same patch of land. There are, for example, more than 270 characters in the Инв. No. 5124-2 land sale contract, dated to the 24th day of the 1st month in the Yin Year of Heavenly Celebration. On the same day, the same land which 無徽媛 [khjiw bie_j ta] had sold, is leased out to 绿 尣样纾 [lhju da kia gji] in the lease contract Инв. No. 5124-3, in about 13 о characters. There, even land size is unmentioned. For it is assumed that the holder of the contract would refer to the land size as recorded in the preceding land sale contract: a patch of land large enough to sow 20 dan of seeds. On the land lease contract, there is no reference to the agents involved, terms of guarantee, location of the four ends of the land. Signatures are simplified, and the name of only one co-Contract Party is registered. There aren't many witnesses, either.

One obvious reason for the relative simplicity of land lease contracts is that, unlike the land sale contracts whereby a title is transferred from one ownership to another (sometimes called an 'absolute sale'), land lease creates a relationship of tenancy, and involves no change of ownership status. Needless to say, that the volume of transaction in land sale is larger than in land lease. It is for these intuitive reasons that land lease contracts are shorter and simpler than land sale contracts. Even the penalty fee is lower in land lease than in land sale: 1 liang versus 2 liang of gold.

\subsubsection{Renter and the Size of Land Leased}

Most of the tenants in the long scroll are peasants either deprived or short of farmland. They have no choice but to work in the fields of the wealthy, and pray for the harvest to cover the rent and, if all goes well, yield some extra earnings left. The following is a chart that compiles the renter, date, and the land size in the 8 land lease contracts.

The ethnicity and demographics of the renters in these 8 contracts are

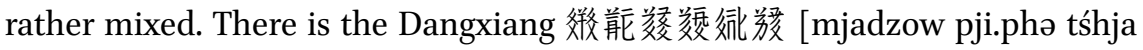
wejr], the Han, Monsieur Su Laofangzi (绿众栟新 [lhju da kia gji]), but the majority are the Liangs, whose identities are not as easy to ascertain. Note that

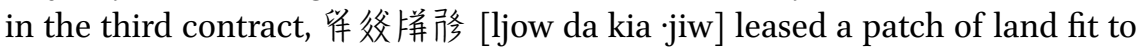
sow 8 dan of seeds from the Pudu Temple, on the 29th Day of the 1st Month in the Yin Year. Looking for his name in the land sale contracts, we quickly find that he sold his own land, fit to sow 15 dan of seeds, to the Pudu Temple on exactly the same day, for which he received a compensation of 6 dan of wheat and 10 dan of coarse grains. What does he have to pay for the lease, assuming that an autumn harvest will materialise? 2 dan 8 dou of wheat and 3 dan 6 dou of coarse grains. Then, in the fourth and sixth contracts, we see that the same 


\begin{tabular}{|c|c|c|c|}
\hline No. & Date of lease & Renter & Land size \\
\hline 1 & 24th Day of 1st Month, Yin Year & 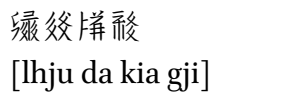 & For 20 dan of seeds \\
\hline 2 & 29th Day of 1st Month, Yin Year & $\begin{array}{l}\text { 傕彺拼面 } \\
\text { [ljow da kia śji-j] }\end{array}$ & For 15 dan of seeds \\
\hline 3 & 29th Day of 1st Month, Yin Year & $\begin{array}{l}\text { 傕咚拼弱 } \\
\text { [ljow da kia } \cdot j i w]\end{array}$ & For 8 dan of seeds \\
\hline 4 & $\begin{array}{l}\text { Same Day } \\
\text { (1st Day of 2nd Month, Yin Year) }\end{array}$ & 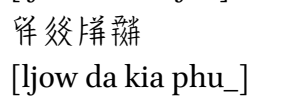 & For 10 dan of seeds \\
\hline 5 & 1st Day of 2nd Month, Yin Year & 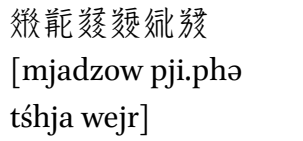 & For 10 dan of seeds \\
\hline 6 & $\begin{array}{l}\text { Same Day } \\
\text { 2nd Day of 2nd Month }\end{array}$ & 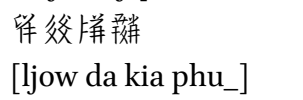 & For 5 dan of seeds \\
\hline 7 & $\begin{array}{l}\text { Same Day } \\
\text { 2nd Day of 2nd Month }\end{array}$ & $\begin{array}{l}\text { 留垓彻鞘 } \\
\text { [ljow ywie gia_phu_] }\end{array}$ & For 5 dan of seeds \\
\hline 8 & $\begin{array}{l}\text { 6th Day of 2nd Month, Year Yin } \\
\text { of Tianqing }\end{array}$ & $\begin{array}{l}\text { 留術挍㸚 } \\
\text { [ljow ywu ne_w mja] }\end{array}$ & For 5 dan of seeds \\
\hline
\end{tabular}

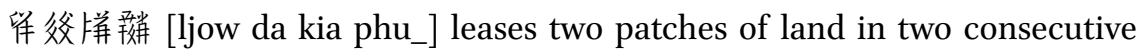
days, one large enough to sow 10 dan, the other 5 dan of seeds. Moreover, this man is a co-Contract Party alongside 留㳇拼務 [ljow da kia -jiw] in the other contract. More often than not, co-Contract Parties are close family relatives. And given the style of their names, it is easy to tell that they may be brothers.

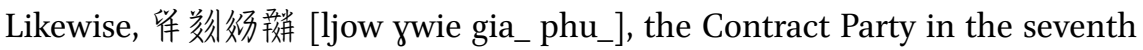

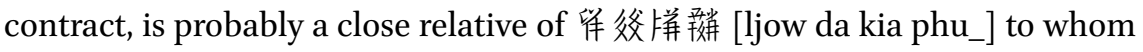
he serves as a co-Contract Party in the fourth contract.

\subsubsection{Rent}

\subsubsection{Calculation of the Rent}

Some land lease contracts indicate the land size in precise statistics, usually in the amount of seeds to be sowed; others refer to the land size as recorded in the preceding land sale contracts. Either way, we have data on land size on each patch of land leased. As for the rent, it is often calculated in the mixed terms of fine (e.g. wheat) and coarse grains. Therefore, it is necessary to convert the real currency into a single unit in order to calculate the average rent per unit of 
land. Fortunatley, we know from Khara-Khoto accounts of grain sales that the price of wheat is around 200-250 mace, whereas the price of millet (a type of coarse grain) is between $150-200 .{ }^{247}$ So it is not without reason to set the price of coarse grains at $75 \%-80 \%$ of the fine grains. In this way, it is also possible to convert all rent into the currency of coarse grains, in order to calculate rent per unit of land, as measured by the space fit to sow 1 dan of seeds. The summary statistics is presented in the chart below.

CHART 20 Rent statistics in the 8 land lease contracts

\begin{tabular}{|c|c|c|c|c|c|}
\hline No. & Renter & $\begin{array}{l}\text { Size of } \\
\text { land } \\
\text { leased }\end{array}$ & $\begin{array}{l}\text { Total rent in mixed } \\
\text { currencies of grains }\end{array}$ & $\begin{array}{l}\text { Total } \\
\text { rent in } \\
\text { coarse } \\
\text { grains }\end{array}$ & $\begin{array}{l}\text { Rent/unit } \\
\text { of land } \\
\text { for } 1 \text { dan } \\
\text { of seeds }\end{array}$ \\
\hline 1 & 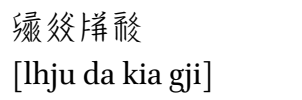 & $\begin{array}{l}\text { For } 20 \text { dan } \\
\text { of seeds }\end{array}$ & $\begin{array}{l}10 \text { dan } 5 \text { dou of wheat \& } \\
5 \text { dan of coarse grains }\end{array}$ & 19 dan & 0.95 dan \\
\hline 2 & 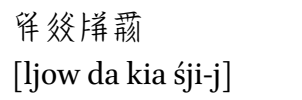 & $\begin{array}{l}\text { For } 15 \text { dan } \\
\text { of seeds }\end{array}$ & $\begin{array}{l}6 \text { dan of coarse grains \& } \\
4 \text { dan } 2 \text { dou of wheat }\end{array}$ & 12 dan & o.8 dan \\
\hline 3 & $\begin{array}{l}\text { 倠父父拼俢 } \\
\text { [ljow da kia ·jiw] }\end{array}$ & $\begin{array}{l}\text { For } 8 \text { dan } \\
\text { of seeds }\end{array}$ & $\begin{array}{l}2 \text { dan } 8 \text { dou of wheat \& } \\
3 \text { dan } 6 \text { dou of coarse } \\
\text { grains }\end{array}$ & $7 \cdot 3$ dan & 0.91 dan \\
\hline 4 & 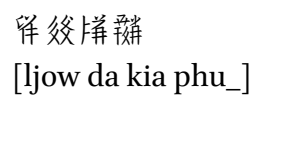 & $\begin{array}{l}\text { For } 10 \text { dan } \\
\text { of seeds }\end{array}$ & $\begin{array}{l}3 \text { dan } 6 \text { dou of coarse } \\
\text { grains \& } 1 \text { dan } 4 \text { dou of } \\
\text { wheat }\end{array}$ & $5 \cdot 5$ dan & 0.55 dan \\
\hline 5 & 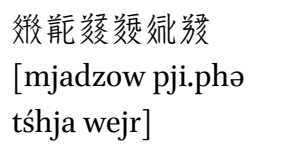 & $\begin{array}{l}\text { For } 10 \text { dan } \\
\text { of seeds }\end{array}$ & 7 dan of wheat, 12 dan & 21.3 dan & 2.13 dan \\
\hline 6 & 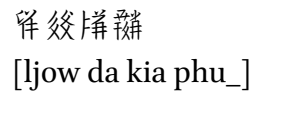 & $\begin{array}{l}\text { For } 5 \text { dan } \\
\text { of seeds }\end{array}$ & $\begin{array}{l}2 \text { dan } 8 \text { dou of wheat \& } \\
5 \text { dan } 4 \text { dou of coarse } \\
\text { grains }\end{array}$ & 9 dan & 1.8 dan \\
\hline 7 & 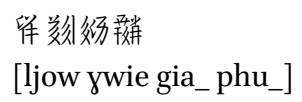 & $\begin{array}{l}\text { For } 5 \text { dan } \\
\text { of seeds }\end{array}$ & $\begin{array}{l}7 \text { dou of wheat \& } 3 \text { dan } \\
5 \text { dou of coarse grains }\end{array}$ & 4.4 dan & o.88 dan \\
\hline 8 & 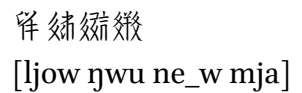 & $\begin{array}{l}\text { For } 5 \text { dan } \\
\text { of seeds }\end{array}$ & 2 dan of coarse grains & 2 dan & 0.4 dan \\
\hline
\end{tabular}

247 Shi, "Commodity Prices, Transaction Taxes and Loans in Western Xia," 2008. 
It turns out that amongst the 8 contracts analysed in the chart, the rent in contract No. 1, 2, 3, 7 are much closer: the renter pays anywhere between 0.8 dan and 1 dan of grains for each unit of land (to sow 1 dan of seeds). In contract No. 5 and 6, however, the rent is much higher, close to or above 2 dan. In contract No. 4, 8, on the other hand, the rent is lower than the average: 0.55 dan and 0.4 dan, respectively. Perhaps a survey of the sale price of the same land would shed some light on the difference in lease price.

CHART 21 Sale price of the land as recorded in the 8 lease contracts

No. Seller

Land size

Price in mixed Price in Price per

Asset included grains coarse unit of grains land (1 dan of seeds)

1 滞微㙹

[khjiw bie_j ta]

2 留父父胼胳

[ljow da kia ·jiw]

$\begin{array}{llll}\text { For } 20 \text { dan } & \text { Coarse grains } & 35 \text { dan } & 1.75 \text { dan } \\ & 15 \text { dan \& } & & \\ & \text { wheat } 15 \text { dan } & \\ \text { For } 15 \text { dan } & 6 \text { dan of wheat } 18 \text { dan } & 1.2 \text { dan } \\ & \& 10 \text { dan of } \\ & \text { coarse grains }\end{array}$

For 8 dan 4 dan of wheat 11.3 dan 1.4 dan $\& 6$ dan of coarse grain

4 篗数拗侈 [ljow ywie gia_.jiw]

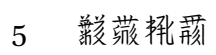
[khjij śja rjar śji-j]

\section{6 篻垓㣢徽} [ljow ywie $\cdot o$ bie_j]

For 5 dan 4 dan of wheat 14.3 dan 2.86 dan

of seeds \& 9 dan of
Ripe/ 2 dan of 8.7 dan 0.87 dan

unripe land wheat,

for 10 dan 2 dan of

of seeds

millet, 4 dan

of grains

Ripe/ 1odan

unripe land of wheat,

for 10 dan 10 dan of

of seeds coarse grain,

10 dan of

millet

33.3 dan 3.33 dan

Cottages large/

small, oxen

ploughs \&

tools, stone

gate with

bamboo fence,

pentamerous

yokes, tree yard

coarse grains 
CHART 21 Sale price of the land as recorded in the 8 lease contracts (cont.)

\begin{tabular}{|c|c|c|c|c|c|c|}
\hline No. & Seller & Land size & $\begin{array}{l}\text { Price in mixed } \\
\text { grains }\end{array}$ & $\begin{array}{l}\text { Price in } \\
\text { coarse } \\
\text { grains }\end{array}$ & $\begin{array}{l}\text { Price per } \\
\text { unit of } \\
\text { land ( } 1 \text { dan } \\
\text { of seeds) }\end{array}$ & $\begin{array}{l}\text { Asset included } \\
\text { in the sale }\end{array}$ \\
\hline 7 & 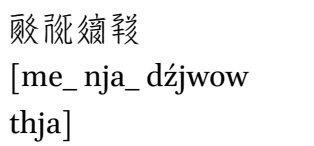 & $\begin{array}{l}\text { For } 5 \text { dan } \\
\text { of seeds }\end{array}$ & $\begin{array}{l}6 \text { dan of } \\
\text { coarse grain \& } \\
1 \text { dan of wheat }\end{array}$ & $7 \cdot 3$ dan & $1.46 \mathrm{dan}$ & \\
\hline 8 & 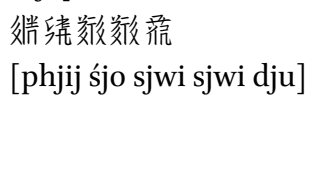 & $\begin{array}{l}\text { Ripe/ } \\
\text { unripe land } \\
\text { for } 3 \text { dan of } \\
\text { seeds }\end{array}$ & $\begin{array}{l}5 \text { dan of } \\
\text { coarse grain }\end{array}$ & 5 dan & 1 dan & $\begin{array}{l}\text { Old house of } \\
4 \text { cabins }\end{array}$ \\
\hline
\end{tabular}

Obviously, the land in lease contract 5 and 6 are rented at higher prices for no other reason than that they are worth more, and were acquired by the landowners at a higher cost. Likewise, the rents in contract 4 and 8 are lower because their sale prices are also lower. There are two main factors that determine land prices. First, fertility and convenience of irrigation usually means higher productivity and yield. Second, all the add-on assets which are sold with the land would also factor in the final listed price. In Contract No. ${ }_{5}$, for example, the land comes with a whole assemblage of major and minor properties: cabins and cottages large and small, tilting tools for the oxen (ploughs, etc.), stone gate with bamboo or wooden fence, five-branched yokes, as well as a tree yard.

\subsubsection{Rent-Sale Price Ratio}

The 12 land sale contracts show that land price in Khara-Khoto is remarkably low, typically around 2 dou of coarse grains per $m u$ of land. There are multiple reasons for this, chief amongst which is the naturally disadvantageous position of the seller pressed by the urgent need of foodstuff in the underproductive seasons of late winter and early spring. The buyers would then exert pressure on the sellers to further cut the price. Typically, the buyers themselves are both grain monopolists, either Buddhist temples or major landlords in the area. They purchase large chunks of land from grain-deprived in the inter-harvest seasons, in order to maximise profit at the expense of needy peasants. As soon as they buy in new land, the new landowner wastes no time to lease it out to peasants, who either lost or sold their land, to extract rents from the landless, who cannot afford to wait to start farming now. In this second round of bargain, 
the landowners again stand to gain from the neediness of the peasants, by raising the rent. The chart shows that the total annual rent is nearly half of what it costs to purchase the land in the first place. In other words, in no more than two years, the landlords could earn back their initial investment. By means of lease, the land quickly pays for itself. The speedy transfer and massive concentration of land property into the hands of landowners in the late-Tangut period is a remarkable phenomenon in economic history.

For instance, in the land sale contract Инв. No. 5124-3(3), 徉㣭姘 [ljow lja mja] of the Pudu Temple purchased from 仵父拼胗 [ljow da kia ·jiw] a patch of land fit to sow 15 dan of seeds, at the cost of 6 dan of wheat and 10 dan of coarse grains. He then immediately leasese the land out, and within a year, he would receive 6 dan of coarse grains and 4 dan 2 dou of wheat in revenuethat is a whopping $2 / 3$ of the purchase cost! In the land sale contracts Инв. No.

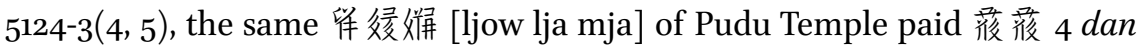
of wheat and 6 dan of coarse grains for a patch of land fit to sow 8 dan of seeds. Here, too, Liang is able to earn back 2 dan 8 dou of wheat and 3 dan 6 dou of coarse grains-nearly $2 / 3$ of the buying cost - within just one year. The high rent-sale price ratio speaks volumes to the exploitation of the landless, grainless peasants at the hands of the financiers, whether a temple or a landlord.

\subsubsection{Guarantee}

Land lease is a form of legal and financial transaction. And for any transaction, there must be a way to guarantee its enforcement. For this reason, Tangut land lease contracts set forth penalties for the violation of the terms. A statement on penalties is usually found immediately after the information on rent.

\subsubsection{Penalty for Breach of Contract and the Legal Force of the Contract}

Terms of penalties for breach of contract in land lease are less exhaustive and severe than in land sale. Below is a chart comparing the summary statistics of penalty fees against default, overdue payment, dispute, or renegation, across the 8 land lease contracts.

In land sales, the chief concern of the purchasing party is whether the seller is transferring full and legitimate property right. The contracts seem to suggest that for the buyer to renege on the contract is a way to question or to deny the proper ownership of the seller. Therefore, the contract specifies that in a scenario where property right is under dispute, liability falls on the side of the seller, who is also obliged to pay the penalty fee, usually double the sale price. Otherwise, any party that reneges on the terms of agreement is penalised. The penalty fee varies from 1 to 3 liang of gold, depending on the size and quality of land concerned. But in case of land lease, the real source of anxiety and 
CHART 22 Penalty fees in the 8 lease contracts compared

\begin{tabular}{|c|c|c|c|c|c|c|}
\hline No. & Renter & Land size & $\begin{array}{l}\text { Overdue } \\
\text { payment }\end{array}$ & $\begin{array}{l}\text { Penalty for } \\
\text { breaching } \\
\text { contract }\end{array}$ & $\begin{array}{l}\text { Penalty for } \\
\text { land sale } \\
\text { dispute }\end{array}$ & $\begin{array}{l}\text { Penalty for } \\
\text { reneging on } \\
\text { the land sale }\end{array}$ \\
\hline 1 & $\begin{array}{l}\text { 鼠父父恲秝 } \\
\text { [lhju da kia gji] }\end{array}$ & $\begin{array}{l}\text { For } 20 \text { dan } \\
\text { of seeds }\end{array}$ & $\begin{array}{l}\text { Doubles } \\
(2 \text { dan } \\
\text { perdan })\end{array}$ & $\begin{array}{l}\text { Penalty Fee } \\
\text { of } 1 \text { liang } \\
\text { of Gold }\end{array}$ & $\begin{array}{l}\text { Doubles } \\
(2 \text { dan per } \\
\text { dan })\end{array}$ & $\begin{array}{l}\text { Penalty Fee } \\
\text { of } 2 \text { liang of } \\
\text { Gold }\end{array}$ \\
\hline 2 & $\begin{array}{l}\text { 倠父父恲荊 } \\
\text { [ljow da kia śji-j] }\end{array}$ & $\begin{array}{l}\text { For } 15 \text { dan } \\
\text { of seeds }\end{array}$ & $\begin{array}{l}\text { Doubles } \\
(2 \text { dan } \\
\text { perdan })\end{array}$ & & $\begin{array}{l}\text { Doubles } \\
(2 \text { dan per } \\
\text { dan })\end{array}$ & $\begin{array}{l}\text { Penalty Fee } \\
\text { of } 3 \text { liang of } \\
\text { Gold }\end{array}$ \\
\hline 3 & $\begin{array}{l}\text { 倠父父恲俢 } \\
\text { [ljow da kia ·jiw] }\end{array}$ & $\begin{array}{l}\text { For } 8 \text { dan } \\
\text { of seeds }\end{array}$ & $\begin{array}{l}\text { Doubles } \\
(2 \text { dan } \\
\text { per dan })\end{array}$ & & $\begin{array}{l}\text { Doubles } \\
(2 \text { dan per } \\
\text { dan })\end{array}$ & $\begin{array}{l}\text { Penalty Fee } \\
\text { of } 1 \text { liang of } \\
\text { Gold }\end{array}$ \\
\hline 4 & $\begin{array}{l}\text { 篟㳇恲靱 } \\
\text { [ljow da kia phu_] }\end{array}$ & $\begin{array}{l}\text { For } 10 \text { dan } \\
\text { of seeds }\end{array}$ & $\begin{array}{l}\text { Doubles } \\
(2 \text { dan } \\
\text { perdan })\end{array}$ & & $\begin{array}{l}\text { Doubles } \\
(2 \text { dan per } \\
\text { dan })\end{array}$ & $\begin{array}{l}\text { Penalty Fee } \\
\text { of } 1 \text { liang of } \\
\text { Gold }\end{array}$ \\
\hline 5 & 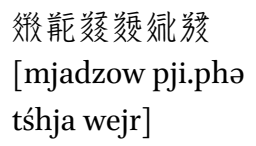 & $\begin{array}{l}\text { For } 10 \text { dan } \\
\text { of seeds }\end{array}$ & $\mathrm{N} / \mathrm{A}$ & & $\mathrm{N} / \mathrm{A}$ & $\begin{array}{l}\text { Penalty Fee } \\
\text { of } 3 \text { liang of } \\
\text { Gold }\end{array}$ \\
\hline 6 & $\begin{array}{l}\text { 倠父拼鞘 } \\
\text { [ljow da kia phu_] }\end{array}$ & $\begin{array}{l}\text { For } 5 \text { dan } \\
\text { of seeds }\end{array}$ & $\begin{array}{l}\text { Doubles } \\
(2 \text { dan } \\
\text { perdan })\end{array}$ & & $\mathrm{N} / \mathrm{A}$ & $\begin{array}{l}\text { Penalty Fee } \\
\text { of } 1 \text { liang of } \\
\text { Gold }\end{array}$ \\
\hline 7 & 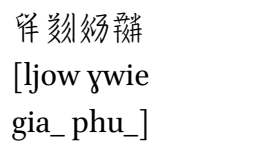 & $\begin{array}{l}\text { For } 5 \text { dan } \\
\text { of seeds }\end{array}$ & $\begin{array}{l}\text { Doubles } \\
(2 \text { dan } \\
\text { per dan })\end{array}$ & & $\mathrm{N} / \mathrm{A}$ & $\begin{array}{l}\text { Penalty Fee } \\
\text { of } 1 \text { liang of } \\
\text { Gold }\end{array}$ \\
\hline 8 & 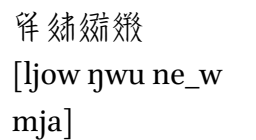 & $\begin{array}{l}\text { For } 5 \text { dan } \\
\text { of seeds }\end{array}$ & $\mathrm{N} / \mathrm{A}$ & & $\begin{array}{l}\text { Penalty fee } \\
\text { of } 5 \text { dan of } \\
\text { wheat }\end{array}$ & \\
\hline
\end{tabular}

flashpoint of contention is not property right but timely payment of rent. Of course, there is also the question of renegation. So, the contract usually contains two statements on penalties: overdue payment and renegation. Penalty fee for overdue payment is based on the rent. Usually, the fee doubles the rent (i.e. for each 1 dan the fee is 2 dan). The volume of transaction in land lease is decidedly smaller than in land sale. Therefore, penalty is also less severe. It is generally uncertain what would happen if a party walks back on his promises and breaches the terms of agreement set forth in the contract. Only the first contract offers clear instructions: the penalty fee is 1 liang of gold. None of the 
other contracts mentions this matter, in particular. It is likely that the landowners are not concerned with the prospect of their tenants ever changing their mind.

\subsubsection{Stamp and Signature}

Consistent with the grain loan accounts and land sale contracts, Khara-Khoto land lease contracts also end with signatures and stamps of the parties involved in the transaction. In most cases, each person occupies a separate line. First comes the Contract Party - the principle party which initiates the transaction, in this case the renter, or the tenant farmer-followed by his liability-sharing co-contractor, and finally the witnesses. There is no more than one principle Contract Party, but there may be multiple co-Contract Parties and witnesses. In these land lease contracts, however, there is usually just 1 co-Contract Party, though sometimes there may be 2 . In contrast, there are 2 or 3 co-Contract Parties in land sale contracts. Likewise, land lease contracts feature 1-2 names of witnesses, versus 2-3 in land sale contracts. In short, whether it comes to the number of co-Contract Parties or witnesses, land lease contracts tend to be shorter and simpler, because it does not involve the absolute transfer of title in large volume. Below is a chart compiled to compare the forms of stamp and signatures in land lease versus land sale contracts.

Also consistent with the format of land sale contracts in the long scroll, the names of sellers, liable parties, and witnesses are all written in a fluent cursive style by a single hand. The handwriting is also exactly the same as in the main text. Therefore, it must have been a professional scriber who wrote out the entire document (apart from the stamps and finger-segment prints).

As expected, the liability-sharing co-Contract Party is referred to, as usual, as 俊张姫 [dźiow sa dźjwi-]: the one (also) receiving the document, i.e. the co-Contract Party. But in the fifth contract, the signatory after the main

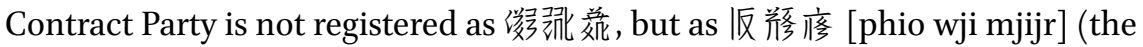
one taking the lease), or "co-renter." This man, by the name of 玮妍 [phjij śjo], claims the same status as that of a co-Contract Party, and also shares liability with the main Contract Party. If the main Contract Party delays or denies payment, dies, escapes, or evaporates, the co-Contract Party takes over the legal obligations and shoulders the financial burden. It is worth noting that the co-Contract Parties in lease contracts are not addressed as family relations to the Contract Party (wife, son, etc.). It also shows that, in contrast to the more serious contracts of land sale, land lease contract requires less rigorous vetting and screening.

Witnesses sign as 版瀞 [nwə dzjwo], literally "the one who knows," i.e. witnesses. It could also be abbreviated into the single-character 版. A point of curiosity is that, whilst the names of the Contract Party and the co-Contract 
CHART 23 Stamps and signatures in the 8 land lease/sale contracts compared

\begin{tabular}{|c|c|c|c|c|c|c|c|c|c|}
\hline No. & $\begin{array}{l}\text { Contract } \\
\text { party }\end{array}$ & $\begin{array}{l}\text { Co- } \\
\text { contract } \\
\text { party/ } \\
\text { parties }\end{array}$ & $\begin{array}{l}\text { Stamp } \\
\text { /Print }\end{array}$ & Witness(es) & $\begin{array}{l}\text { Stamp } \\
\text { /Print }\end{array}$ & $\begin{array}{l}\text { Co- } \\
\text { contract } \\
\text { parties in } \\
\text { land sale }\end{array}$ & $\begin{array}{l}\text { Stamp } \\
\text { /Print }\end{array}$ & $\begin{array}{l}\text { Witness(es) } \\
\text { in land sale }\end{array}$ & $\begin{array}{l}\text { Stamp } \\
\text { /Print }\end{array}$ \\
\hline 1 & 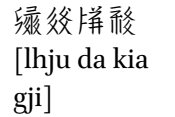 & 1 & Stamp & 1 & Stamp & 2 & $\begin{array}{l}\text { Finger- } \\
\text { segment }\end{array}$ & 3 & $\begin{array}{l}\text { Finger- } \\
\text { segment, } \\
\text { Stamp }\end{array}$ \\
\hline 2 & $\begin{array}{l}\text { 留徐恲罚 } \\
\text { [ljow da kia } \\
\text { sji-j] }\end{array}$ & 1 & Stamp & 2 & $\begin{array}{l}\text { Finger- } \\
\text { segment }\end{array}$ & 3 & $\begin{array}{l}\text { Finger- } \\
\text { segment }\end{array}$ & 3 & $\begin{array}{l}\text { Finger- } \\
\text { segment }\end{array}$ \\
\hline 3 & $\begin{array}{l}\text { 留徐恲胗 } \\
\text { [ljow da kia } \\
\text {.jiw] }\end{array}$ & 1 & Stamp & 2 & stamp & 2 & $\begin{array}{l}\text { Finger- } \\
\text { segment }\end{array}$ & 2 & Stamp \\
\hline 4 & 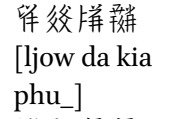 & 2 & Stamp & 2 & $\begin{array}{l}\text { Finger- } \\
\text { segment }\end{array}$ & 3 & $\begin{array}{l}\text { Finger- } \\
\text { segment, } \\
\text { stamp }\end{array}$ & 2 & $\begin{array}{l}\text { Finger- } \\
\text { segment }\end{array}$ \\
\hline 5 & 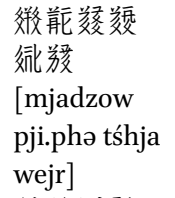 & 1 & Stamp & 2 & $\begin{array}{l}\text { Finger- } \\
\text { segment }\end{array}$ & 2 & $\begin{array}{l}\text { Stamp, } \\
\text { Finger- } \\
\text { segment }\end{array}$ & 2 & $\begin{array}{l}\text { Finger- } \\
\text { segment }\end{array}$ \\
\hline 6 & $\begin{array}{l}\text { 倠㸚拼抒 } \\
\text { [ljow da kia } \\
\text { phu_] }\end{array}$ & 2 & Stamp & 2 & $\begin{array}{l}\text { Finger- } \\
\text { segment }\end{array}$ & 3 & $\begin{array}{l}\text { Stamp, } \\
\text { Finger- } \\
\text { segment }\end{array}$ & 2 & $\begin{array}{l}\text { Finger- } \\
\text { segment }\end{array}$ \\
\hline 7 & 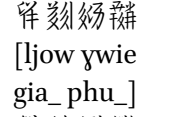 & 1 & Stamp & 2 & $\begin{array}{l}\text { Stamp, } \\
\text { Finger- } \\
\text { segment }\end{array}$ & 2 & $\begin{array}{l}\text { Stamp, } \\
\text { Finger- } \\
\text { segment }\end{array}$ & 2 & $\begin{array}{l}\text { Stamp, } \\
\text { Finger- } \\
\text { segment }\end{array}$ \\
\hline 8 & 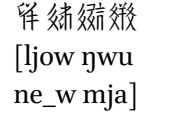 & 1 & Stamp & 2 & $\begin{array}{l}\text { Finger- } \\
\text { segment }\end{array}$ & o & & 2 & $\begin{array}{l}\text { Finger- } \\
\text { segment }\end{array}$ \\
\hline
\end{tabular}

Party are written in parallel, the names of witnesses are usually one or a half space higher. This is probably a way to distinguish between two kinds of legal personae: the Contract Party and co-Contract Party share substantive liability, whereas the witnesses are there only to fulfil a legal function. If things go awry, the witnesses may be consulted, but are under no substantive obligation.

There are, as usual, two ways to authenticate the legal document: by stamping a pictorial icon, or by drawing the signatory's finger-segments. Most of the Contract Parties and co-Contract Parties in land lease contracts paint a symbol or icon, but witnesses choose either way. For instance, in contract Инв. No. 5124-3(3) the Contract Party, co-contractor, and one of the two witnesses stamped their symbols, whereas the other witness printed his finger-segments. 
Then, in Инв. No. 5124-3(5), all renters, co-renters, and witnesses stamped their symbols. Whereas in Инв. No. 5124-3(2), the co-Contract Party stamped, whereas the both witnesses chose to print their finger-segments.

\subsubsection{Features of Tangut Land Lease Contracts}

Along with the land sale contracts, Khara-Khoto land lease contracts constitute a major part of the primary sources on the history of socio-economic activities in Western Xia. These manuscripts accurately portray how land was used, farmed, and transacted in rural areas of Western Xia, at the very bottom level of the Tangut society.

\subsubsection{Key Materials for the Study of the Tangut Economy}

Khara-Khoto land lease contracts provide fresh, real, and detailed primary materials for the study of the Tangut economy. These texts are also key to any survey of medieval Chinese, East Asia, Inner Asian, and world economic history. For the first time, they make it possible for the academia to gain deep and reliable insights into the distribution, transfer, and use of farmland. Moreover, it is not a single piece, but a batch of documents that are discovered. A connective and comparative reading of these economic records yields new forms of knowledge unimaginable in the past.

\subsubsection{Reflection on the Socio-Economic and Living Conditions in Khara-Khoto}

The value of Tangut land lease contracts goes beyond the historical study of land use, per se, but informs a full understanding of the Khara-Khoto socioeconomy and the living conditions of ordinary Tanguts during this period. The contracts show that a number of Tangut peasants lacked farmland, and therefore resorted to land lease. They obtain leases at exorbitant prices, suffering multiple rounds of exploitation, wagering entirely on a harvest to pay for their debt and to maintain subsistence. They gamble it all on the autumn harvest, even though they are fully aware of high risks and uncertainties when it comes to the yield. The fact that in Khara-Khoto, where population was not the densest and arable land not the scarcest, land lease was under such enormous pressure, speaks to the harsh realities on the ground.

\subsubsection{Monopolistic Acquisition of Land by Temple Establishments}

The Khara-Khoto land lease contracts also reveal the extent to which Buddhist temples engaged in predatory, monopolistic acquisitions and transactions of scarce farmland. Pudu Temple purchases land en masse at low prices, and lease them out at higher prices to peasants either without or short of land to 
farm. In two rounds of transactions, the temple is able to extract a huge sum of revenues from the peasants. Purchased and leased, a patch of land typically pays for itself in a year or two.

\subsubsection{Land Lease Contract Is Shorter and Simpler than Land Sale Contracts}

Within the long scroll of legal documents, each land lease contract concerns the same patch of land as in the preceding land sale contracts. For this reason, some information is omitted in the land lease contract, under the assumption that the two contracts are kept and read in conjunction. Moreover, given that land lease is not as risky and significant as land sale, there is no need for such details as the four boundaries of the land, tax information, sources of irrigation, etc. Since a lease contract involves no 'absolute sale,' even the terms of penalties are rather succinct. Furthermore, fewer co-Contract Parties and witnesses are involved in land lease than in land sale. These points of comparison show that Tangut contracts are, after all, flexible and practical documents.

\subsection{Land Lease and Livestock Mortgage}

At times, Tangut peasants in Khara-Khoto had to mortgage their livestock in order to secure land leases. This is a further complicated case of an otherwise simple lease of farmland. Such contracts are rare to find. So far, only one has been successfully identified.

The manuscript Инв. No. 5949-30 is a "contract of farmland lease and livestock mortgage" dated to the Chen year of Yingtian (1208 AD). The original piece is a single-page contract of 15 lines in cursive Tangut handwritten on a $21.1 \times 45.5 \mathrm{~cm}$ hemp paper. The document begins with the date, "Yingtian, Chen Year, Last month, 21st Day" and ends with the stamp and signature. ${ }^{248}$

This contract is written in a remarkably cursive style, with many characters simplified from their standard forms, making it even more difficult to render a clean text. The first two characters in the first line should be, according to conventions, the era title of the year. The first character looks like 酸 [ywər] (heaven). The second one is decisively unclear, written almost in a single stroke. But we could infer it as 预 [

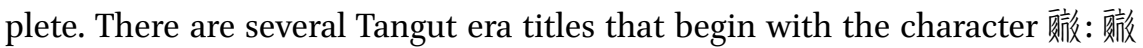

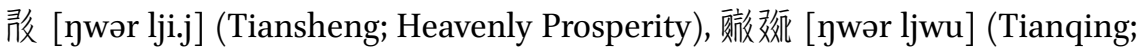

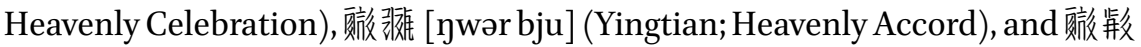
[ywər dzji.] (Huangjian; Imperial Foundation). Given the shape of the second character here, the era title intended in this case could only be 橏涨 (Yingtian).

248 Russian Collection of Khara-Khoto Manuscripts, vol. 14, p. 92. 


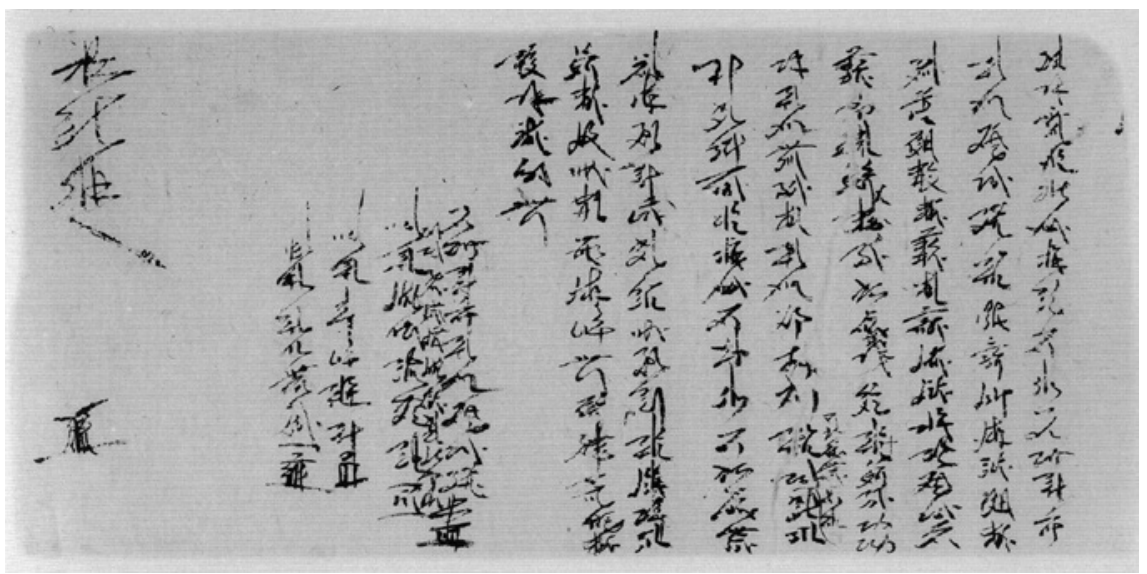

FIGURE 187 Инв. No. 5949-3о: Chen year of Yingtian (1208) contract of farmland on livestock, et al. mortgage

We gain a much stronger sense of certainty in our reading of the mysterious character as 致, not least because the second character in line 9 of the text is also written in this shape, and in that context, also, the character is best read as 涨. When the Russian Collection of Khara-Khoto Manuscripts was first published, the contract was mislabelled "Tianqing" or "Heavenly Celebration," which should now be corrected to "Yingtian" or "Heavenly Accord." The contract was signed on the 21st day of the last month in year 1208 .

Despite the radical cursiveness of the script, it is still possible to interpret the basic meaning of the text as a whole. The contract was signed on the 21st day of the last month in 1208 - that is, in the late-Tangut period, less than 20 years before the fall of the empire-by a certain 羓朘效航横 [-jaxwa phə phji ta], who leased out a patch of land fit for 1 dan 5 dou of seeds, on a mortgage of his own donkey. In addition, he has to pay a rent of 1 dan 5 dou of coarse grains to the land-owner, Yehe Xianling et al., due by the first day of the second month in the following year. Overdue payment will be duly penalised.

Contracts which concern large assets and major factors of production such as land and livestocks are extremely important, and therefore usually wordy, formal, and complicated. The contract is validated by iconic stamps rather than an approximate print of finger-segments. The contract ends with there large characters in ink: 梅胮? [ya. nji-_?] (two-ten-?), which might be another indication of the date, above the stamps. Given the conventional format of more formal contracts, the space at the end of the document may be reserved for signatories of higher status. If we survey the stamps and signatures here, we see a line written in smaller font: "co-Contract Party, wife Eyi 'the joy of 
the old house" was evidently inserted into the text at a later time. So, it seems that the name, which was not there at first, was added at the insistence of the land-owner, to whom the legal presence of a co-Contract Party's signature is not dispensable. This lady, Eyi, is the wife of the Contract Party - the party which takes the lease on livestock mortgage. With her formally involved in the contract, the document is more secure and enforceable. But to look at it from another angle, we see again the indisputable socio-economic status of women, especially if they are female heads of households, in the inner lives of the Tangut society.

Most of the relevant parties involved in the contract, whether it is M. Yehe himself, or his wife Eyi, or still the witnesses Weiyi, Liang, and Yehe, are Dangxiang Tanguts. M. Liang, however, could be either an ethnic Fan or a Han - the exact truth, we shall never know. It shows that a large number of Tanguts engaged in agriculture, including both wealthy land-owners and impoverished peasants.

Contracts of land lease on livestock mortgage are rare finds amongst Tangut manuscripts. To interpret them is as necessary as demanding. There is a lot of room for further studies.

The broad category of Tangut "employment contracts" includes both human and animal labour contracts. By Contracts of Labour Employment, the employed human beings offer their physical work in exchange for a set amount of compensation. By Contracts of Livestock Employment, those in shortage of draft animal labour hire draft animals from livestock-owners, for which they pay a fee. Both types of contracts were used in Western Xia, and prove important sources to the study of Tangut society and economy.

\subsection{Employment of Human Labour}

Contracts of human labour employment is a key source on the identities of the Tanguts employed for physical labour-their names, socio-economic status, and relationship to the employer. Amongst the copious manuscripts discovered in the city of Khara-Khoto, thus far, only one complete document of Labour Employment Contract has been identified. But to see from the macroscopic temporal horizon, this manuscript is probably the best labour employment contract from the Liao, Song, Xia, and Jin Dynasties. It fills in the void of 11th-13th century Chinese labour contract. 
$5 \cdot 1.1$

Translation and Interpretation of Tangut Contracts of Labour Employment

The Инв. No. 5949-32 Labour contract is dated to the last month in the Mao Year of Guangding (1219), a single-page, $19.8 \times 47.9$ manuscript with 15 lines handwritten in the Tangut cursive and standard-running scripts. The first line begins with the date: "Mao Year of Guangding, Last month, Fifth Day" (1219); the contract ends in a standard format, with stamps and signatures. ${ }^{249}$

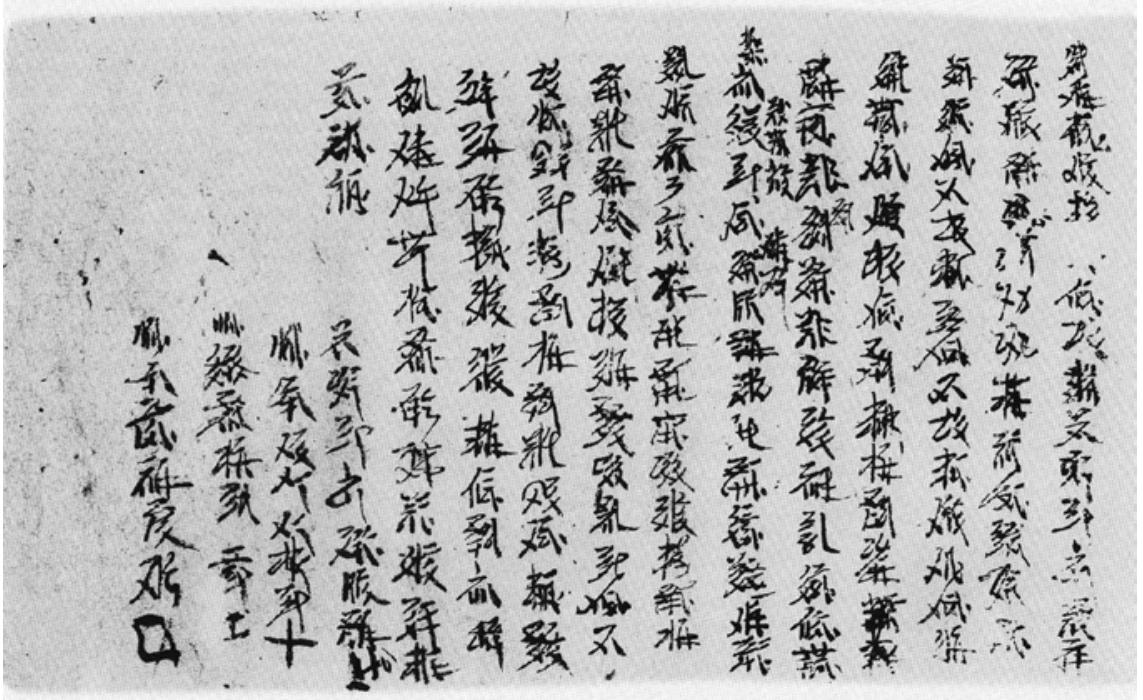

FIGURE 188 Инв. No. 5949-32: Mao year of Guangding (1219) contract of labour employment

Translation:

On the $5^{\text {th }}$ day of the last month in the Chen Year of Guangding, Contract set by Babe Quan-

fenmao, presently voluntarily at ???'s place, from

the 1st day of the 1st month to the 1st day of the 1oth month, for 9 months, offers employed

labour, at the price of 5 dan, 2 dan of which is paid immediately; in the autumn

249 Russian Collection of Khara-Khoto Manuscripts, vol. 14, p. 94. 
the other 3 dan is paid, along with 3 zhang of white cloth for summer clothing. He himself plants 5 dou

2 sheng of coarse grains, 3 dou of wheat, to be certain. Let 㖁镀靱 [khjwilji- phu_] make his best effort,

Without deceits or evasions; if he acts arbitrarily, or is absent during a busy day, for each day

He has to work for 2 days. If the rest of the wage is not paid by the 1st day of the roth month,

For each dan let the employer pay 2 dan. Whoever regrets and reneges on these agreements,

Pays the penalty of 5 dan of coarse grains according to the law. But only are the two parties willing in their hearts, but let them enforce the terms herein contained in the document, and according to the circumstances.

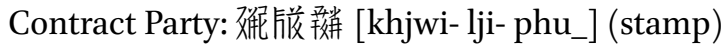

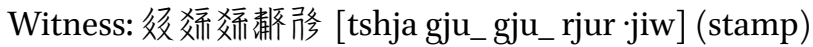

Witness: 釉㷙垪绫 [mja dzow kə zji] (stamp)

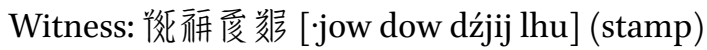

5.1.2 Interpretation of the Basic Content in the Contracts

This important piece of labour contract offers an abundance of information: the time of the contract, the Contract Party (the employed labourer as the primary party that sets up the contract), the employer, the duration of the employment, wage, terms of employment, as well as penalties for default and violations of the contract, followed by the signatures and stamps of both parties. The format is that of a complete contract. Indeed, it is a rich and accurate reflection of labour employment in Western Xia.

The contract must have been negotiated and signed in the Mao Year of Guangding — during the reign of the Shenzong Emperor of Western Xia. There are 13 years in this period, and only one of them is a Mao Year. Therefore, we know almost for certain that the contract was signed in the last month of 1220, towards the late period of the Tangut Empire-only 7 years from its fall.

The reference to the 'maker of the contract'一荇㻐瓶廖 [-jwi-r dźiow wji mjijr] — is the same as in other types of Tangut Contracts. The labourer here who sets up the contract is Babe 唃镀档 [khjwi-lji- phu_] (the prosperous dog manure). The family name 嗳 [ba be] appears under the section of 'Tangut names'in both the Assorted Words of the Three Realm and the New Collection of Golden Fragments in the Palm. ${ }^{250}$ In the tunnelway of Cave 61 in the Mogao

250 Russian Collection of Khara-Khoto Manuscripts, vol. 10, pp. 49, 110. 
Grottoes of Dunhuang, on the back of the Tejaprabhā Buddha on the Southern wall, there is a portrait of votive Bhikkhunī figure. By its side, one finds her

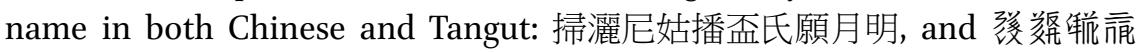

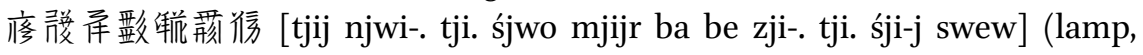
burn, vow, emanate, person, Ba, Be, name née, wish, become, light). A literal translation of the Tangut is: "The lamp-lighting, vow-taking one, Babe, prays for enlightenment." 251 This nun is most probably an ethnic Tangut woman. The same family name is also found in Tangut documents and seals of military chiefs. Therefore, the employed labourer in this Contract of Labour Employment is a Tangut man of the Babe family. There is also much to be said about his given name. The Tanguts devised diverse names for their children. Some are meant to be auspicious; others indicate the months and years in which the child is born; some feature Buddhist imageries and jargons, others borrow from low-status humans and even animals: "an auspicious dog," "dog of the old house," "the one with a donkey," "the rain-bird," "the benevolent slave," "the slave-treasure," etc. It is possible that these less-than-flattering names were meant to ward off the jealousy of the spirits, making it easier to raise the children to their adulthood. A "dog's manure," otherwise "prosperous," is a fitting example of such a naming strategy. A similar example is a certain witness

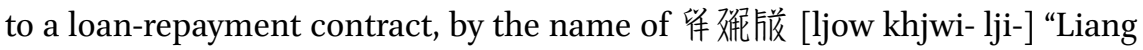
'the dog manure." 252 As for the five-character name of the employer in the contract, most of them are blurred, so much so that they can hardly be identified. But it is quite possibly a Tangut name, as well.

The contract is clearly dated to the last month of the Mao Year of Guangding. The labour is employed from the first day of the first month in the upcoming year - that is, the first day of the Gengchen Year of Guangding (1220) - to the first day of the tenth month, a total duration of 9 months that encompass the spring, summer, and autumn. The labourer is to work from the sowing season to the harvesting season.

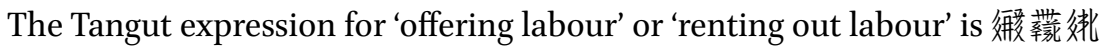
[yie tshwew lho]. This phrase echoes the legal expression in the Tangut Laws of

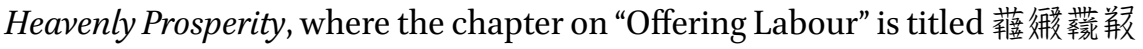
[rar yie tshwew ya] (pawn/rent, labour, offer, gate/chapter/section). The two characters in the middle for "offering labour" is the same as in this contract.

251 Bai, Bin; Shi, Jinbo. “Mogaoku Yulinku Xixiawen Tiji Yanjiu” [莫高窟榆林窟西夏文題 記研究]: “A Study of Tangut Inscriptions in the Yulin Cave of Mogao Grottoes" in Kaogu Xuebao [考古學報]: Acta Archaeologica Sinica, issue 3, 1982.

252 Russian Collection of Khara-Khoto Manuscripts, vol. 13, p. 318. 
The labourer's wage is 5 dan of grains. The contract stipulates, in lucid language, that of the total wage, 2 dan is pre-paid at the signing of the contract. The other 3 dan is paid only in the harvest season. Apart from the grains, the employers are obliged to offer summer clothings to the employed. The Tangut expression is 终䍩 [tsja gjwi] (hot, cloth = clothes in the hot season, i.e. summer clothing). These summer clothings will be made out of the ' 3 zhang of white cloth' provided for by the employer. In addition, the employers are allowed to plant 5 dou and 2 sheng of coarse-grain seeds, as well as 3 dou of wheat seeds in a patch of land, out of their own labour and for their own enjoyment. These numbers here measure land size by seeds. The Tanguts measured land by qing or $m u$, but also by the amounts of seeds to be sowed. If the land for 1 dan of seeds is roughly equivalent to 4 (Song) $m u \approx 10$ Tangut $m u$, then the labourer concerned in this contract is permitted to farm a little more 3 (Song) $m u$ of land, where 8 dou of seeds are sowed.

By a stipulation of the contract, the employer also requires that the employee exert his utmost physical power. The requirement of making an effort is in the

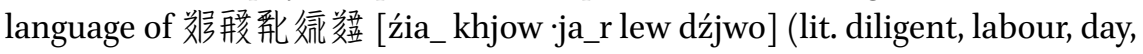
should, devote), that is, the labourer is expected to devote his labour with diligence during the working days. The contract also expects no deceit from the labourer, asking that he not to miss any work for private reasons. Emphatically, the contract makes clear that during the busy season, any work day missed has to be made up for by two additional workdays. The Tangut expression 䛓荆

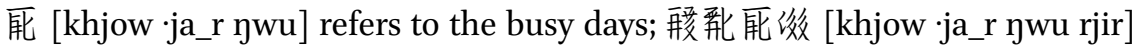
means to leave work undone during the busy days.

But the contract also secures the labourer's right to receive the second payment in the harvest season. If the 3 dan of grains are not paid to the worker by the first day of the tenth month, for each 1 dan of wage, the employer has to pay 2 dan. In general, if either party walks back on the promises outlined in the agreement, the penalty is the standard 5 dan of coarse grains, according to Tangut law. Both parties express their willingness to abide by the terms laid out in the contract, and to enforce them according to the requirement of particular circumstances. Overall, it can be said that the contract restrains the economic conduct of both parties: the employing and the employed.

The contract ends with the signatures and stamps of the Contract Parties and the witnesses. Since the family name of the Contract Party, Babe, already appears at the start of the contract, a given name suffices at the end. There are three witnesses, two of which are ethnic Tanguts: 多交系 [tshja gju_] and 释 龍 [mjadzow]; the third, a Yang, is most probably a Han. Given that the handwritings of the four signatories, as well as the main text of the document, are nearly identical, it is possible that a single scriber wrote and signed the entire 
contract. The 'signatures' are followed by stamps. As discussed before in this book, there are two kinds of stamps: a symbol or a print of the finger-segments. Icons and Images are more formalistic. They are used most often when there are multiple Contract Parties and co-Contract Parties. Finger-segments are usually preferred by the witnesses. Given the importance of this labour-employment contract, all stamps take the form of iconic symbols.

5.1.3 The Economy of Labour-Employment as Reflected in the Contracts Labour employment is an important issue in socio-economic lives of the Tanguts. There is a long tradition of labour-employment in China, but the practice of hiring workers is seldom documented in conventional historical archives. So far, a small but impressive body of surviving ancient Contracts of Labour Employment, most of which excavated in modern eras, have been identified: Han-dynasty labour employment contracts in Han-slips; Gaochang Labour Employment Contracts in Turfan dated to the Wei, Jin, Northern and Southern dynasties; Labour Employment Contracts in Turfan and Dunhuang dated to the Tang and Five Dynasties, as well as early-Song contracts unearthed in Dunhuang. ${ }^{253}$ This manuscript of Tangut Labour Employment Contract, excavated in Khara-Khoto to the northeast of Dunhuang, adds one more temporal geographical perspective to the list.

The contracting party in this Contract of Labour Employment is an ethnic Tangut man. Historically, the first Dangxiang Tanguts engaged in pasturing and livestock-raising. But once relocated to more arable lands, they gradually pivoted to agriculture, hence the significant presence of Tangut peasants in the Khara-Khoto documents. In this particular labour contract, both the employer and the hired, and even the two witnesses, are Dangxiang Tanguts. It shows that in the span of two centuries, some Tanguts became highly-skilled and employable farmers.

By definition, labour contracts reflect the legal relationship in between the employer and the labourer in terms of rights and obligations - that is, one party offers compensations for the service provided by the other. This contractual relationship is founded upon mutual and voluntary agreement. Contract-making is recorded in the chapter on "hiring labour" in the Laws of Heavenly Prosperity:

253 Zhang, Chuanxi. Zhongguo Lidai Qiyue Cuibian [中國歷代契約粹編]: An Edited Collection of Contracts in All Chinese Dynasties (upper tome). Beijing: Peking University Press, 2014, pp. 72-73, 175-177, 369-388, 613-619. 
With the exception of the shijun, the wives and sons of the many and of their lords, the men and women of those in government, given mutual consent, and according to texts official or private, may practice of hiring. ${ }^{254}$

That is basically another way of stating that, by Tangut laws, it is legal to hire labourers (lit. to 'pawn' or 'mortgage' labour). The expression for "offering

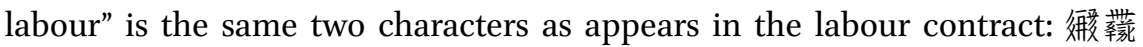
[rie tshwew].

What are the living conditions and family backgrounds of the particular employer concerned in this contract? For what reasons does he hire additional labour? Is it out of an ordinary shortage of hands, or an over-abundance of land? These 'motives' are not revealed to or hinted at within the compass of the text. Perhaps they are buried in history and never to be known.

The labour is contracted for a span of 9 months, which almost entails a whole-year schedule. It may be considered a 'long-term hire.' There is, after all, little or nothing to do in the fields during the three coldest months in the winter.

In this labour contract, as in most others, the price of labour-or the wage of the hired labourer-is calculated in terms of grains. The compensation is 5 dan of grains. With a bit of research, we know that a unit sheng of wheat in Western Xia weighs about 1 modern Chinese jin (shijin). A unit dan of grains is, therefore, approximately 100 jin in our own terms. But on top of this standard payroll, the employer grants his labourer the right to farm on around 3 (Song) $m u$ of land. Given the much lower fertility, hence productivity at the time, one $m u$ of land must have yielded no more than a few dou of grains, definitely below 1 dan. Even if we allow that the high yield of 1 dan per $m u$ was occasionally possible, the total yield would have been no more than 4 dan. That is to say, the total pay for the labourer here is 8 dan of grains. His monthly wage then comes down to nearly 1 dan of grains. In addition, he receives free summer clothings from the employer. But it is very likely that these clothes would up with wears and tears by the end of the year.

On average, an adult consumes about 5 dan of grains per year. Suppose that the labourers are fed at the employer's expense during the workdays. It is very much possible, then, that he would be able to feed one adult and one child in his own family by his annual earnings. Tangut grain loan accounts show that, toward the last few years of Western Xia, a large number of peasants in Khara-Khoto, especially in a state of penury in the interim months between

254 Revised Laws of Heavenly Prosperity 11, “On Hired Labour," p. 388. 
one harvest and the next, resorted either to taking high-interest loans from exploitative creditors, or to sell their land or livestocks in exchange for foodstuffs. In addition to grains for dietary purposes, the peasants were also in need of seeds to sow in whatever bits and pieces of land that remained in their possessions. Now, this particular labourer is bound to his work all year long. If his family also owns land, no matter how little, he would not be able to plough his own fields. In that case, the optimal solution is to outsource his land to others. Or, perhaps, he could be one of the many landless peasants at the time. It would have been extremely difficult for him to pull it off, if indeed, he had to feed his wife and children by his daily exertion of labour, alone. With the 2 dan of grains he procures in the spring, a family of three or four were barely going to make it to the autumn harvest. But if the household was privileged enough to have enjoyed extra labour, then his annual earnings of 8 dan or so would be an impressive income.

The labour contract makes an emphatic point about the necessity to make the best effort in the fields. No procrastination is tolerated. Delay and dereliction of duty on a busy work day would result in two additional days of labour as penalty. In a total of about 270 days, regardless of weather at the time and the physical condition of the labourer, he is bound to intensive and endless work. Therefore, despite the seeming 'contractual equality' between the two legal personae, it must be said that the employer is in a position of advantage if not outright domination. There is even a relationship of subordination between the hiring and the hired. The contract makes an explicit reference to penalty in accordance with laws should the terms of the agreement ever be violated. In fact, the Tangut laws go to great lengths to secure the rights of the employers, to the extent of validating unequal terms and conditions:

If a hired labourer, bound to his service, fails to perform the tasks, and the employer beats him to death, let him be sentenced to one year of imprisonment. If the aggressor uses tools to torture the labourer to death, let the imprisonment be three years. If the death is caused by premeditated murder, let the case be judged according to the laws on premeditated murders. ${ }^{255}$

That is to say, if an employer beats his unperforming worker to death by hand, accidentally and unintentionally, he is to suffer no more than one year in prison. The use of weapon upgrades the manslaughter, resulting in three years of imprisonment. Only when intention and premeditation can be proved,

255 Revised Laws of Heavenly Prosperity 11, “On Hired Labour," pp. 388-389. 
would the case be tried as a case of murder. Needless to say, the Tangut laws are a product of the feudal time and order. They are therefore sensitive to caste and hierarchy. Offences committed by those of lower status against their superiors are punished much more than if the power relation is the other way around. ${ }^{256}$ The Tangut laws are explicit about such structural legal inequalities:

If the hired labourer rapes the employer's wives, daughters, daughtersin-law, aunts, sisters, etc., let the charge be three levels higher than what is stipulated in Book VIII on the wives of others ...

Let no labourer beat, resist, or verbally abuse the employer. In case of a violation, and if the employer is a commoner, let a labourer who hurled verbal insults suffer thirteen strokes, and let a labourer who launched physical attacks be jailed for one year. If the labourer causes any injury, then let the charge be three levels above the normal charge of physical violence; if a death is caused, let the perpetrator of the crime be hanged. If the labourer verbally insults an office-holder of high status, let him be jailed for one year; if physical violence is involved, let the imprisonment be two years. If any injury is caused, let the charge be five levels higher than a normal charge of physical harm. Should the struggle result in death, let the perpetrator be cut by a sword ...257

Rape or sexual harassment committed by the hired to the female members of the employer's household are three levels higher than usual. Any verbal or physical attacks against one's employer also results in much heavier punishments than under normal circumstances-that is, when the socio-legal statuses of the involved parties are equal. Obviously, then, the employers and their employees are in a fundamentally unequal legal relationship. In fact, it is misleading to characterise it as a relationship of employment, for it comes strikingly close to the relationship between a lord and his servants. The Laws of Heavenly Prosperity also require that:

If Shijun [semi-slaves], Nupu [servants/serfs], Dianren [hired men], and the like should steal the written records of their mortgage ... let them be tried according to the laws of theft. ${ }^{258}$

256 Revised Laws of Heavenly Prosperity 8, "On Caused Injuries," pp. 296-297.

257 Revised Laws of Heavenly Prosperity 11, p. 389.

258 Revised Laws of Heavenly Prosperity 3, "Miscenllaneous Crimes of Theft," p. 167. 
Neither the semi-slaves of military origin, nor the household servants and serfs owned their own legal persons. They are the Tangut equivalents of the Tangut and Song-era Buqu or Nubi. ${ }^{259}$ Here, the Tangut law lists the hired men alongside the serfs and slaves. It is perhaps the most striking testimony to the low social status of hired labour in the Tangut economy and society.

Of course, the contract also seems to have restrained the actions of the employers. After all, according to the terms of agreement, should the employer fail or refuse to deliver the second payment to the labourer in the amount of 3 dan of grains, then for each 1 dan owed to the employee, he now has to pay 2 dan, intead. It should be carefully noted that that such terms are not coercive. Nor do they really impose any pressure or difficulty upon the employers, or at least not at the level enforcement and execution of the rights and duties. Still, in evident contrast to the unilateral nature of grain loan, land sale, or livestock contracts, this document of labour contract at least outlines the contours of bilateral duties, and moreover, the precise terms and forms of penalties for both sides, should either of them ever walk back on his promise. It reflects a certain degree - certainly not a high or adequate degree — of balance between the rights and the duties of both parties.

The stamps and signatures of this contract also testifies to ethnic diversity and cross-ethnic demographics in the rural areas of Khara-Khoto. The employer, the labourer hired, as well as the first and second witnesses, all seem to be Dangxiang Tanguts. The third witness is a certain Yang, most probably an ethnic Han. Since he is invited be a witness to the contract, he must have been a close associate of the labourer concerned. Of course, the close Fan-Han ties shown here is consistent in other economic records of Western Xia, such as grain loan and land sale contracts.

\subsubsection{Comparisons with Tang and Song Labour Employment Contracts}

Amongst the many social documents discovered in the celebrated Dunhuang library cave, some are clearly labour contracts. Labour contracts in agriculture dated to the Tang, Song, and the Five Dynasties are, however, rare finds. A total of fifteen such contracts are accurately dated, and have well survived. The Tangut labour contract with which we are principally concerned here comes slightly later than this batch of Dunhuang manuscripts, but there is a lot of discernable temporal and geographical continuity there, nonetheless. To start with the obvious, all of these papers originate from the northwestern area of China. Dunhuang and Khara-Khoto are only 1 degree apart in latitude; both

259 Shi, Jinbo. Xixia Shehui [西夏社會]: Tangut Society. Shanghai: Shanghai People's Press, 2007, pp. 221-227. 
cities enjoy an arid inner-continental climate, with much draught, little rain, and cold wintry days. Even today, the difference in the average temperatures of the two is a mere matter of 1 degree Celsius. For these and many reasons, the geographical and meteorological conditions of agricultural production in the two areas are, and still remain, strikingly similar and completely comparable.

Indeed, the format and content of these 15 labour contracts and the Tangut contract share a great deal of similitude. Almost all contracts begin with the date of the contract and the name of the principle party in the contract, then proceed to specify the duration of the employment, the wage, terms and requirements, recompensations for neglected work, penalties for violations of the terms, and end with the stamps and signatures of all concerned parties. Although the Tangut labour contract is written in the Tangut language by Dangxiang-Tanguts, the legal document itself inherits, or imitates, the Chinese tradition of contract. It again shows the profound social, legal, and cultural impact of the migration into the agricultural zones of the Chinese Central Plains on the Tanguts, who had for so long relied on pasturing, hunting, and livestock-raising.

For a thorough analysis of the Tangut labour contract in comparison with the Tang and early-Song (9th-1oth centuries) contracts, I have compiled the 15 contracts of long-term agricultural labour in the chart below, alongside the Tangut labour contract. ${ }^{260}$

It is self-evident that employers hire labour only when short-handed. Most Tang and Song labour employment contracts document the precise reasons of the hire: "because the household is short of hands," "since there is a shortage of human labour," "given that the family lacks sufficient labour" etc. Tangut contracts, however, do not contain these expressions. The omission of formulaic, programmatic, and probably superfluous legal language renders the contract much more concise. Not only in the Contracts of Labour Employment, but also in land sale and grain loan contracts, the Tanguts tend to omit these contextual explanations.

There is yet another difference between Tang, Song and Tangut contracts of labour employment. Most of the labour contracts dated to the Tang and Song eras record the precise addresses of the employers and the employees. For example, Linghu Anding's labour employment contract in Dunhuang documents that the employed labourer lives in Longle Village, whereas the employer

26 Dunhuang Economic Documents, vol. 2, pp. 55-71. Some of the contracts only indicate the sexagenary cycle but not the era names. See also Zhang, Chuanxi, Upper Tome, 2014, pp. $376-382 ; 613-62$. 
CHART 24 Tang, Song, and Tangut labour contracts compared

\begin{tabular}{|c|c|c|c|c|c|c|c|c|}
\hline Register & $\begin{array}{l}\text { Title of the } \\
\text { contract }\end{array}$ & Time & $\begin{array}{l}\text { Employed } \\
\text { labourers }\end{array}$ & Employers & $\begin{array}{l}\text { Duration } \\
\text { of hire }\end{array}$ & Wage & $\begin{array}{l}\text { Clothing } \\
\text { provisions }\end{array}$ & $\begin{array}{l}\text { Penalty } \\
\text { for } \\
\text { negligence }\end{array}$ \\
\hline 1 & $\begin{array}{l}\text { Linghu } \\
\text { Anding of } \\
\text { Dunhuang, } \\
\text { Contract } \\
\text { of Labour } \\
\text { Employment }\end{array}$ & $\begin{array}{l}\text { Wuxu Year } \\
(878 ?)\end{array}$ & $\begin{array}{l}\text { Commoner } \\
\text { Long Cong'er }\end{array}$ & $\begin{array}{l}\text { Commoner } \\
\text { Linghu } \\
\text { Anding }\end{array}$ & $\begin{array}{l}\text { 1st to the } \\
\text { end of the } \\
\text { 9th month }\end{array}$ & $\begin{array}{l}5 \text { douper } \\
\text { month }\end{array}$ & $\begin{array}{l}\text { 1 pair of } \\
\text { spring } \\
\text { clothes; } \\
\text { shirt; } \\
\text { pants and } \\
\text { shoes }\end{array}$ & $\begin{array}{l}1 \text { dou per } \\
\text { day }\end{array}$ \\
\hline 2 & $\begin{array}{l}\text { Zhang Naji, } \\
\text { Contract } \\
\text { of Labour } \\
\text { Employment }\end{array}$ & $\begin{array}{l}\text { Jiayin Year } \\
(894)\end{array}$ & $\begin{array}{l}\text { Commoner } \\
\text { Jiu Han'er }\end{array}$ & $\begin{array}{l}\text { Commoner } \\
\text { Zhang Naji }\end{array}$ & $\begin{array}{l}\text { 1st to } \\
\text { 9th month }\end{array}$ & $\begin{array}{l}1 \text { load } \\
\text { of millet } \\
\text { sold per } \\
\text { month }\end{array}$ & $\begin{array}{l}\text { Spring } \\
\text { clothes; } \\
\text { shirt ... }\end{array}$ & missing \\
\hline 3 & $\begin{array}{l}\text { Kang } \\
\text { Baozhu of } \\
\text { Dunhuang, } \\
\text { Contract } \\
\text { of Labour } \\
\text { Employment }\end{array}$ & $\begin{array}{l}\text { Renwu } \\
\text { Year } \\
(922 ?)\end{array}$ & $\begin{array}{l}\text { Commoner } \\
\text { Zhao } \\
\text { Jinjiangnan }\end{array}$ & $\begin{array}{l}\text { Commoner } \\
\text { Kang } \\
\text { Baozhu }\end{array}$ & $\begin{array}{l}\text { 1st to the } \\
\text { end of the } \\
\text { 9th month }\end{array}$ & $\begin{array}{l}1 \text { load } \\
\text { per } \\
\text { month }\end{array}$ & $\begin{array}{l}\text { Spring } \\
\text { clothes } \\
\text { 1 pair; } \\
\text { shirt 1; } \\
\text { pants } \\
\text { 1 set; } \\
\text { leather } \\
\text { shoes } \\
\text { 1 pair }\end{array}$ & missing \\
\hline 4 & $\begin{array}{l}\text { Yin Sijia of } \\
\text { Dunhuang: } \\
\text { Contract of } \\
\text { Employment }\end{array}$ & $\begin{array}{l}\text { Fourth } \\
\text { Year of } \\
\text { Longde } \\
\text { in Later } \\
\text { Liang } \\
(924)\end{array}$ & $\begin{array}{l}\text { Commoner } \\
\text { Yin Sijia }\end{array}$ & $\begin{array}{l}\text { Commoner } \\
\text { Zhang Sijia }\end{array}$ & $\begin{array}{l}\text { 2nd to the } \\
\text { end of the } \\
\text { 9th month }\end{array}$ & $\begin{array}{l}1 \text { load } \\
\text { over a } \\
\text { month }\end{array}$ & $\begin{array}{l}\text { Spring } \\
\text { clothes } \\
\text { 1 pairs; } \\
\text { long- } \\
\text { sleeved } \\
\text { sacrificial } \\
\text { gown; } \\
\text { leather } \\
\text { shoes } \\
\text { 1 pair }\end{array}$ & $\begin{array}{l}2 \text { dou per } \\
\text { day }\end{array}$ \\
\hline 5 & $\begin{array}{l}\text { Han } \\
\text { Zhuang'er of } \\
\text { Dunhuang: } \\
\text { Contract of } \\
\text { Employment }\end{array}$ & $\begin{array}{l}\text { Jiashen } \\
\text { Year } \\
(924 ?)\end{array}$ & $\begin{array}{l}\text { Commoner } \\
\text { Han } \\
\text { Zhuang'er }\end{array}$ & $\begin{array}{l}\text { Commoner } \\
\text { Su Liunu }\end{array}$ & $\begin{array}{l}\text { 1st to the } \\
\text { end of the } \\
\text { 9th month }\end{array}$ & $\begin{array}{l}\text { Wheat } \\
\text { + millet: } \\
6 \text { loads }\end{array}$ & missing & missing \\
\hline
\end{tabular}


CHART 24 Tang, Song, and Tangut labour contracts compared (cont.)

\begin{tabular}{|c|c|c|c|c|c|c|c|c|}
\hline Register & $\begin{array}{l}\text { Title of the } \\
\text { contract }\end{array}$ & Time & $\begin{array}{l}\text { Employed } \\
\text { labourers }\end{array}$ & Employers & $\begin{array}{l}\text { Duration } \\
\text { of hire }\end{array}$ & Wage & $\begin{array}{l}\text { Clothing } \\
\text { provisions }\end{array}$ & $\begin{array}{l}\text { Penalty } \\
\text { for } \\
\text { negligence }\end{array}$ \\
\hline 6 & $\begin{array}{l}\text { Deng Wuzi of } \\
\text { Dunhuang, } \\
\text { Contract of } \\
\text { Employment }\end{array}$ & $\begin{array}{l}\text { Yiyou Year } \\
(925 ?)\end{array}$ & $\begin{array}{l}\text { Commoner } \\
\text { Deng Wuzi }\end{array}$ & $\begin{array}{l}\text { Monk } \\
\text { Baoxiang } \\
\text { of the } \\
\text { Qianyuan } \\
\text { Temple }\end{array}$ & $\begin{array}{l}8 \text { months } \\
\text { from } 12 \text { th } \\
\text { day of } 2 \text { nd } \\
\text { month }\end{array}$ & $\begin{array}{l}1 \text { load } \\
\text { per } \\
\text { month }\end{array}$ & $\begin{array}{l}\text { Spring } \\
\text { clothes, } \\
\text { long- } \\
\text { sleeved } \\
\text { gown 1, } \\
\text { trousers } \\
\text { for gown } \\
\text { 1 set; } \\
\text { leather } \\
\text { shoes } \\
\text { 1 pair }\end{array}$ & $\begin{array}{l}5 \text { dou } \\
\text { per day } \\
\text { in busy } \\
\text { months; } \\
1 \text { dou in } \\
\text { leisurely } \\
\text { months }\end{array}$ \\
\hline 7 & $\begin{array}{l}\text { Yao } \\
\text { Wenqing of } \\
\text { Dunhuang, } \\
\text { Contract } \\
\text { of Labour } \\
\text { Employment }\end{array}$ & $\begin{array}{l}\text { Fourth } \\
\text { Year of } \\
\text { Tianfu in } \\
\text { Later Jin } \\
\text { (939) }\end{array}$ & $\begin{array}{l}\text { Commoner } \\
\text { Chengyi } \\
\text { Shennan }\end{array}$ & $\begin{array}{l}\text { Commoner } \\
\text { Yao } \\
\text { Wenqing }\end{array}$ & $\begin{array}{l}\text { (since) 1st } \\
\text { day of the } \\
\text { 1st month }\end{array}$ & $\begin{array}{l}1 \text { load } \\
\text { per } \\
\text { month }\end{array}$ & $\begin{array}{l}\text { Spring } \\
\text { clothes } \\
\text { 1 pair; } \\
\text { long- } \\
\text { sleeved } \\
\text { [gown] } \\
\text { 1; shirt 1; } \\
\text { plain- } \\
\text { cloth } \\
\text { trousers } \\
\text { 1 set; } \\
\text { leather } \\
\text { shoes } \\
\text { 1 pair }\end{array}$ & $\begin{array}{l}2 \text { dou per } \\
\text { day }\end{array}$ \\
\hline 8 & $\begin{array}{l}\text { Li Yuanchang } \\
\text { of Dunhuang, } \\
\text { Contract of } \\
\text { Employment } \\
\text { of Peng } \\
\text { Zhangsan }\end{array}$ & $\begin{array}{l}\text { Wushen } \\
\text { Year (948) }\end{array}$ & $\begin{array}{l}\text { Commoner } \\
\text { Peng } \\
\text { Zhangsan }\end{array}$ & $\begin{array}{l}\text { Commoner } \\
\mathrm{Li} \\
\text { Yuanchang }\end{array}$ & $\begin{array}{l}\text { 1st month } \\
\text { to the end } \\
\text { of the } 9 \text { th } \\
\text { month }\end{array}$ & $\begin{array}{l}1 \text { load } \\
\text { per } \\
\text { month }\end{array}$ & $\begin{array}{l}\text { Spring } \\
\text { clothes, } \\
\text { shirt 1, } \\
\text { pants and } \\
\text { long- } \\
\text { sleeved } \\
\text { gown, } \\
\text { leather } \\
\text { shoes } \\
\text { 1 pair }\end{array}$ & $\begin{array}{l}2 \text { dou } \\
\text { per day } \\
\text { in busy } \\
\text { times; } 1 \\
\text { dou in a } \\
\text { leisurely } \\
\text { day }\end{array}$ \\
\hline 9 & $\begin{array}{l}\text { Ma Yingde of } \\
\text { Dunhuang, } \\
\text { Contract of } \\
\text { Employment }\end{array}$ & $\begin{array}{l}\text { Yimao } \\
\text { Year } \\
(955 ?)\end{array}$ & $\begin{array}{l}\text { Commoner } \\
\text { Ma Yingde }\end{array}$ & $\begin{array}{l}\text { Commoner } \\
\text { Meng } \\
\text { Yading }\end{array}$ & $\begin{array}{l}\text { 1st month } \\
\text { to the end } \\
\text { of the } 9 \text { th } \\
\text { month }\end{array}$ & $\begin{array}{l}\text { 8douper } \\
\text { month }\end{array}$ & $\begin{array}{l}\text { Spring } \\
\text { clothes; } \\
\text { shirt; } \\
\text { leather } \\
\text { shoes } \\
\text { 1 pair }\end{array}$ & $\begin{array}{l}2 \text { dou per } \\
\text { day on a } \\
\text { busy day; } \\
1 \text { dou if } \\
\text { otherwise }\end{array}$ \\
\hline
\end{tabular}


CHART 24 Tang, Song, and Tangut labour contracts compared (cont.)

\begin{tabular}{|c|c|c|c|c|c|c|c|c|}
\hline Register & $\begin{array}{l}\text { Title of the } \\
\text { contract }\end{array}$ & Time & $\begin{array}{l}\text { Employed } \\
\text { labourers }\end{array}$ & Employers & $\begin{array}{l}\text { Duration } \\
\text { of hire }\end{array}$ & Wage & $\begin{array}{l}\text { Clothing } \\
\text { provisions }\end{array}$ & $\begin{array}{l}\text { Penalty } \\
\text { for } \\
\text { negligence }\end{array}$ \\
\hline 10 & $\begin{array}{l}\text { He Baoding } \\
\text { of Dunhuang, } \\
\text { Contract } \\
\text { of Labour } \\
\text { Employment }\end{array}$ & $\begin{array}{l}\text { Dingsi } \\
\text { Year } \\
(957 ?)\end{array}$ & $\begin{array}{l}\text { Commoner } \\
\text { Long } \\
\text { Yuandingnan }\end{array}$ & $\begin{array}{l}\text { Commoner } \\
\text { He Baoding }\end{array}$ & $\begin{array}{l}\text { One full } \\
\text { year }\end{array}$ & $\begin{array}{l}1 \text { load } \\
\text { per } \\
\text { month }\end{array}$ & $\begin{array}{l}\text { Spring } \\
\text { clothes } \\
\text { 1 pair; } \\
\text { shirt 1; } \\
\text { long- } \\
\text { sleeved } \\
\text { gown; } \\
\text { pants } \\
\text { 1 set; } \\
\text { leather } \\
\text { shoes } \\
\text { 1 pair }\end{array}$ & $\begin{array}{l}2 \text { dou per } \\
\text { day }\end{array}$ \\
\hline 11 & $\begin{array}{l}\text { Li Jichang of } \\
\text { Dunhuang, } \\
\text { Contract of } \\
\text { Employment } \\
\text { of Wu Zhu'er }\end{array}$ & $\begin{array}{l}\text { Xinyou } \\
\text { Year } \\
(961 ?)\end{array}$ & $\begin{array}{l}\text { Commoner } \\
\text { Wu Zhu'er }\end{array}$ & $\begin{array}{l}\text { Commoner } \\
\text { Li Jichang }\end{array}$ & 9 months & $\begin{array}{l}1 \text { load } \\
\text { per } \\
\text { month }\end{array}$ & missing & missing \\
\hline 12 & $\begin{array}{l}\text { Dou Boti of } \\
\text { Dunhuang, } \\
\text { Contract of } \\
\text { Employment } \\
\text { of Deng } \\
\text { Yanshou }\end{array}$ & $\begin{array}{l}\text { Jiaxu Year } \\
(974 ?)\end{array}$ & $\begin{array}{l}\text { Deng } \\
\text { Yanshou }\end{array}$ & $\begin{array}{l}\text { Commoner } \\
\text { Dou Boti }\end{array}$ & 9 months & $\begin{array}{l}1 \text { load } \\
\text { per } \\
\text { month }\end{array}$ & $\begin{array}{l}\text { Spring } \\
\text { clothes } \\
\text { 1 pair; } \\
\text { shirt 1; } \\
\text { pants } \\
\text { 1 set; } \\
\text { leather } \\
\text { shoes } \\
\text { 1 pair }\end{array}$ & $\begin{array}{l}2 \text { dou } \\
\text { per day } \\
\text { in busy } \\
\text { times; } \\
1 \text { dou } \\
\text { otherwise }\end{array}$ \\
\hline 13 & $\begin{array}{l}\text { Fan } \\
\text { Zaisheng of } \\
\text { Dunhuang, } \\
\text { Contract of } \\
\text { Employment } \\
\text { of Fan } \\
\text { Zaiyuan }\end{array}$ & $\begin{array}{l}\text { Guiwei } \\
\text { Year } \\
(983 ?)\end{array}$ & $\begin{array}{l}\text { Commoner } \\
\text { Fan Zaiyuan }\end{array}$ & $\begin{array}{l}\text { Virtuous } \\
\text { Commoner } \\
\text { Fan } \\
\text { Zaisheng }\end{array}$ & $\begin{array}{l}\text { 1st day to } \\
\text { the end } \\
\text { of the 9th } \\
\text { month }\end{array}$ & $\begin{array}{l}1 \text { load } \\
\text { per } \\
\text { month }\end{array}$ & $\begin{array}{l}\text { Spring } \\
\text { clothes } \\
\text { 1 pair; } \\
\text { shirt 1; } \\
\text { pants } \\
\text { 1 set; } \\
\text { leather } \\
\text { shoes } \\
\text { 1 pair }\end{array}$ & $\begin{array}{l}2 \text { dou } \\
\text { per day } \\
\text { in busy } \\
\text { times; } \\
\text { (missing } \\
\text { below) }\end{array}$ \\
\hline 14 & $\begin{array}{l}\text { Deng } \\
\text { Handuo } \\
\text { Contract } \\
\text { of Labour } \\
\text { Employment }\end{array}$ & $\begin{array}{l}\text { Dinghai } \\
\text { Year }(987)\end{array}$ & $\begin{array}{l}\text { Commoner } \\
\text { Geng } \\
\text { Handuo }\end{array}$ & $\begin{array}{l}\text { Commoner } \\
\text { Deng } \\
\text { Handuo }\end{array}$ & 1 full year & $\begin{array}{l}1 \text { load } \\
\text { per } \\
\text { month }\end{array}$ & $\begin{array}{l}\text { Spring } \\
\text { clothes ... }\end{array}$ & \\
\hline
\end{tabular}


CHART 24 Tang, Song, and Tangut labour contracts compared (cont.)

\begin{tabular}{|c|c|c|c|c|c|c|c|c|}
\hline Register & $\begin{array}{l}\text { Title of the } \\
\text { contract }\end{array}$ & Time & $\begin{array}{l}\text { Employed } \\
\text { labourers }\end{array}$ & Employers & $\begin{array}{l}\text { Duration } \\
\text { of hire }\end{array}$ & Wage & $\begin{array}{l}\text { Clothing } \\
\text { provisions }\end{array}$ & $\begin{array}{l}\text { Penalty } \\
\text { for } \\
\text { negligence }\end{array}$ \\
\hline 15 & $\begin{array}{l}\text { Shi Fansan of } \\
\text { Dunhuang, } \\
\text { Contract of } \\
\text { Employment } \\
\text { of Du } \\
\text { Yuanchang }\end{array}$ & $\begin{array}{l}\text { Wuzi Year } \\
(988 ?)\end{array}$ & $\begin{array}{l}\text { Commoner } \\
\text { Du } \\
\text { Yuanchang }\end{array}$ & $\begin{array}{l}\text { The Liang } \\
\text { Household, } \\
\text { Shi Fansan }\end{array}$ & missing & $\begin{array}{l}8 \text { dou } \\
7 \text { sheng? } \\
\text { per } \\
\text { month }\end{array}$ & $\begin{array}{l}\text { Spring } \\
\text { clothes; } \\
1 \text { shirt }\end{array}$ & $\begin{array}{l}2 \text { dou } \\
\text { per day } \\
\text { in busy } \\
\text { times; } \\
1 \text { dou } \\
\text { otherwise }\end{array}$ \\
\hline 16 & $\begin{array}{l}\text { Babe } \\
\text { Quanfenmao, } \\
\text { Contract } \\
\text { of Labour } \\
\text { Employment }\end{array}$ & $\begin{array}{l}5^{\text {th day }} \\
\text { of last } \\
\text { month, } \\
\text { Chen } \\
\text { Year of } \\
\text { Guangding }\end{array}$ & $\begin{array}{l}\text { Babe } \\
\text { Quanfenmao }\end{array}$ & $\begin{array}{l}\text { Ning } \\
\text { Liqing? }\end{array}$ & $\begin{array}{l}\text { 1st month } \\
\text { to } 1 \text { st } \\
\text { day of } \\
\text { the 1oth } \\
\text { month, } \\
\text { duration } \\
\text { of } \\
9 \text { months }\end{array}$ & $\begin{array}{l}5 \text { dan; } \\
\text { land for } \\
8 \text { dou } \\
2 \text { sheng } \\
\text { of grains }\end{array}$ & $\begin{array}{l}\text { Summer } \\
\text { Clothes, } \\
3 \text { zhang } \\
\text { of white } \\
\text { cloth }\end{array}$ & $\begin{array}{l}2 \text { days } \\
\text { of work } \\
\text { per day } \\
\text { missed. }\end{array}$ \\
\hline
\end{tabular}

resides in Hongrun Village. Precise documentation of addresses furnishes the contract with an additional layer of security; perhaps more importantly to modern historians, it makes it possible to study the economic geography of medieval labour relations, and even the human geography and historical geography of the past. In contrast, Tangut Contracts of Labour Employment barely divulge any information on the dwelling places of the employers and the labourer. Tang and Song contracts also provide fuller and more accurate socio-economic identities of the parties involved. Again in the Linghu Andi's contract in Dunhuang, we know the labourer as "commoner Long Cong'er" and the employer as "Commoner Linghu Anding"; in Deng Wuzi's contract in Dunhuang, the labourer is "Commoner Deng Wuzi" and the employer is "Monk Baoxiang at the Qianyuan Temple"; the contract of Fan Zaisheng in Dunhuang registers the employee as "commoner Fan Zaiyuan" and the employer as "A particularly virtuous commoner Fan Zaisheng." Again, barely any identity-markers could be found in Tangut labour contracts.

Most of the Dunhuang labour contracts dated to the Tang, Five Dyansties, and early-Song periods, are drafted in the first or second lunar month of the year. The labourer is hired for about 8 or 9 months. Only two contracts of mark the duration of work as an entire year: (1) He Baoding's Labour Employment Contract in Dunhuang, in the Dingsi Year (957?) is signed on the 7th day of the 4 th month, effective for an "entire year" - that is, until the 4th month of 
the following year; (2) Deng Handuo's Labour Employment Contract in the Dinghai Year (987) is signed on the 23rd day of the 1st month, for the next "full cycle of a year." The Tangut Labour contract is set up in the last month of the previous year. The terms of employment are effective for 9 full months in the following year, from the first day of the first month to the first day of the tenth month. In other words, the labourer has to get started on the very first day of the New Year, missing the opportunity to celebrate the holiday.

When it comes to the wages, there is some variety amongst Tang and Song labour contracts. The Tang contract dated to the Wuxu year features thus far the lowest wage: " 5 dou per month." Most other contracts indicate a wage around the level of 1 'load' per month—-that is, 1 dan, or 1 shuo. Elsewhere, in two documents, the wage appears slightly less, either 8 dou or slightly more. In the Tangut labour contract with which we are presently preoccupied, the employer promises 5 dan of grains, and in addition, permits the hired worker to till a patch of land where the seeds of 5 dou 2 sheng of coarse grains and 3 dou of wheat are sowed. The harvest is estimated to be more than 3 dan if all goes well. That makes the total payment a little less than 9 dan. It is worth remarking that the area of Khara-Khoto is in no scarcity of land, necessarily, although the fertility and unit-productivity of the soil may be suboptimal. The harsh reality faced by any hired labourer is principally the uncertainty of produce and harvest. It can never be safely assumed that $1 \mathrm{mu}$ of land is going to yield anything around 1 dan of grains, especially on land tilled for their own enjoyment. Not to mention, of course, that employers have few clothings to offer to their workers. It must be said, therefore, that the wage in the labour employment contract we have from Western Xia is short of impressive. But the low wage rate is also easy to explain in the context of social upheavals, into the final years of the Tangut Empire. The regime was simultaneously battling the Jurchens and suffering Mongol invasions. As a major city along the northern frontier, the Khara-Khoto population proved an easy and natural casualty. Ten years prior to the signing of this contract, the Mongols for the first time breached the walls of Khara-Khoto. There, the Mongol army steered southward to the imperial Capital, the city of Zhongxing. Then, 5 years after this contract, in $1225 \mathrm{AD}$, Khara-Khoto was once again taken by the Mongols. The second fall of the city unveiled the curtains of the Mongol destruction of Western Xia and started the beginning of the end of Tangut power. It could only be imagined what the circumstances were surrounding the arrangement for this labourer's work in the fields amidst such chaos. ${ }^{261}$ It usually happens that during wars and unrests, both land and labour prices fall, whilst the cost of the highest of

261 Wu, Tianchi. Xixia Shigao [西夏史稿], Beijing: Commercial Press, 2010, pp. 111-124. 
all necessities, the grains, skyrockets to incredible heights. The fall of the land prices in the late Tangut period has been sufficiently and convincingly demonstrated by the land sale contracts analysed in this book. Now, we point to the data in this labour contract to demonstrate the economic-historical phenomenon of falling labour prices in the last years of Western Xia.

It should also be noted that Tang and Song labour employment contracts tend to be rather detailed and strict in preventive measures against default and indiscreet behaviours. They even elaborate on the consequences of the labourers damaging the farming tools. In the contract of Linghu Anding, dated to the Wuxu Year $(878$ ?), for example, it is clearly stipulated that:

Once the contract is established, let the concerned party enter his duty of work, and let him never abandon his labour. One day of negligence results in the penalty of 1 dou [of grains.] Should a matter of life and death emerge, a leave of 3 days is permitted. But thereafter, let him immediately resume work. All the farming tools and other properties are entrusted to Cong'er. Let him not unreasonably beat the cattles and the livestocks. If he does beat them, and thus violate the rules, let him recompensate the owner. ${ }^{262}$

Another example is the labour contract of Deng Wuzi in Dunhuang, dated to the Yiyou Year (925?):

From the day the labourer enters into his employment, let him diligently proceed to work, day after day, and month after month. Let him never cast aside his work duties. If in a busy season, he leaves one day of work undone, let him pay 5 dou as recompensation. If his negligence occurs at a rather leisurely time, the penalty is 1 dou instead. Wuzi has entrusted all of his farming tools in his possession to the labourer. If the worker loses them, let him recover the loss. If the worker falls sick, let him be granted five days to deal with the malady. Should he take more days of rest, those days will come at the expense of his wage. ${ }^{263}$

The contract of Ma Yingde of Dunhuang in the Yimao Year (955?) states the following:

262 Dunhuang Economic Documents 55, in Zhang, Chuanxi, 2014, Upper Tome, p. 377.

263 Dunhuang Economic Documents 7o, in Zhang, Chuanxi, 2016, Upper Tome, pp. 381-382. 
The owner of the land has entrusted all the hoes and plows needed for the work to Yingde. Should these tools be lost, let Yingde recompensate the costs. If they are handed to the owner of the household, then let the liability not fall on Yingde. If Yingde casts aside his duty in a busy workday, let him pay 2 dou of grains as a penalty; if the day is not so busy, let him pay 1 dou, instead. ${ }^{264}$

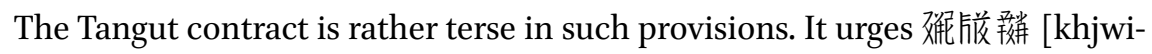
lji- phu_] to make his maximum effort, never to deceive or misrepresent information, or to find pretexts and excuses to neglect his duties. If he were ever to act imprudently or arbitrarily, or fail to show up at a busy time, he is obliged to work for two days to compensate for each day neglected. But here, there is no provision for where liability lies in case the tools are damaged or lost. Nothing is said about sick days, either. It is striking that there is no statement on a three-day or five-day paid-leave, should the labourer fall seriously ill. So, a reasonable absence due to illness or disability would have been treated as absence. Surely, this is not an arrangement that by any minimal standard tends to the basic rights and benefits of the labourers. But in comparison to the Tang and Song contracts, the Tangut contract stipulates a lower rate of compensation for neglected work. In the Dunhuang contracts-depending on whether they operate a legal distinction between 'busy' versus 'non-busy' days-punish each day of neglected work with 2 dou or 1 dou of grains. In some extreme cases, the penalty on a busy day is as much as 5 dou (See the Dunhuang contract of Monsieur Deng Wuzi). The Tangut contract, on the other hand, asks for 2 days of labour to cover each busy day neglected. It is possible that if nobody is in a hurry, then the labourer should feel free to work only 1 additional day to cover each day neglected. Given a monthly wage of 1 dan of grains, a penalty of 1 dou of grains is worth 3 days of wage; 2 dou of grains are the labour costs of 6 days; at the same rate, 5 dou of grains are the wage for half a month! Therefore, the ' 2 days for each (busy) day neglected' requirement is less of a burden than in the Dunhuang contracts.

Every single contract specifies the terms of penalties for default. The Dunhuang contract of Linghu Anding, for example, states that "if one party first breaches the contract, let the penalty be one sheep, to be transferred to the party that does not breach the contract." In the Dunhuang contract of Han Zhuang'er, "the party which first breaches the contract is to transfer two loads of green wheat to the non-breaching party." Again, in the contract of Deng Wuzi, "A party that breaches the contract is punished 5 shuo of wheat, to be

264 Ibid. 
claimed by the person who does not breach the agreements." It seems that the penalty turns severe over the course of time. So is the case in the Tangut contract, where the party which walks back on its promise has to surrender 5 dan of coarse grains, in accordance with the laws. 5 dan is a heavy punishment. The contract cites the Tangut laws as a reference. We do find in the Laws of Heavenly Prosperity, that:

Let the many who engage in transactions or loans, as well as other forms of associations with other parties, out of their voluntary will, establish written records, whereupon let them note down the relevant words, concerning the price of transactions, quantity of the money, as well as the conditions ... thereafter, if any party reneges on these words, let him be punished: if he were an office-holder, let him submit the payment directly to the government; if he were a private man, let him transfer the sum privately to the other party. ${ }^{265}$

By this law, labour employment seems to fall into the rather broad category of "other forms of associations with other parties" for a variety of matters. Given the distinction between the public and the private, surely the man hiring another man for agricultural labour falls into the private domain. Therefore, the penalty fee would probably go into the hands of the other party, which does not renege on the agreements.

Expectedly, the contract ends with the stamps and signatures of the concerned parties. The most important, however, seem to be those of the hired labourer. The employer does not actually sign his name or stamp his symbol. In the light of the aforementioned provisions against the theft of legal records in the Laws of Heavenly Prosperity, it seems that these types of contracts are preserved in the hands of the employers. It could have been the case also in the Tang and Song contracts. In other words, the contracts are unilateral promises made by the labourers to their employers. There, too, the inequality is self-evident. ${ }^{266}$

In sum, the Tangut labour contract, the only surviving contract of labour employment dated to the 11-13th centuries, reflects the economic activity of hiring labour in the later history of Western Xia. It reveals a wide range of

265 Revised Laws of Heavenly Prosperity 3, "Urging the Payment of Debt and Interest," pp. 189-19o.

266 Mie, Xiaohong. "Zailun Dunhuang Nongye Gugongqi zhong de Guyong Guanxi” [再 論敦煌農業僱工契中的僱傭關係]: “Another Discussion on the Labour-Employer Relationship in the Employment Contracts in Agriculture found in Dunhuang” Zhongguo Jingjishi Yanjiu [中國經濟史研究]: Researches in Chinese Economic History, issue 4, 2011. 
details concerning the economics of labour and employment. It is also a side, sectional, and microscopic view of the Tangut agriculture. The Tangut labour contract receives from and builds upon the Chinese contract tradition. Its further simplification of both format and content, decrease in wage and increase in labour intensity, as well as a more salient relationship of subordination, could all have been the result of socio-economic instability in the last years of the Tangut Empire. ${ }^{267}$

\subsection{Employment of Livestock}

Contracts of Livestock Employment constitute an important legal genre in the economic and legal history of China. Yet, few Livestock Employment contracts survive to the present day. There are a mere 6 contracts of livestock employment from the Tang and Song era. These contracts of camel, oxen, and donkey draft were found in the Cave Library in Dunhuang. Every single one of them is of tremendous historical value. So far, five Khara-Khoto contracts of livestock labour have been identified in the corpus of Khara-Khoto manuscripts. One of them, the document Инв. No. 2996-3 is the tail end of a long scroll. Three others are included within the No. 5124 scroll of contracts. Before each of the three contracts of livestock employment, there is one contract of livestock sale. In fact, the animals being rented out to perform draft labour (per livestock employment contracts) have just been purchased from the hands of impoverished peasants. Another piece is the partially damaged manuscript Инв. No. 19-2. Fortunately, the main content is preserved alright. In most contracts of livestock employment, the term for 'employing' a draft animal is 勇 [kwo], which sounds very much like the Chinese 僱 [kuH] (to hire, to employ). Historically, the term 'to employ', like the verb 'to contract or rent at a fixed price,' is likely to have been a loan word from medieval Chinese. In all likelihood, employment in this sense had not been a socio-legal norm to the Tanguts prior to their reception of Han culture, hence the absence of any vocabulary that denotes it in the Tangut language. But after the migration northward, the Dangxiang people developed more complex modes and relations of production - such as contractual employment of human and animal labour - as the Tanguts were increasingly drawn to and integrated with economy of the Central Plains.

267 Shi, Jinbo. “Heishuicheng Chutu Xixiawen Gugongqi Yanjiu” [黑水城出土西夏文僱 工契研究]: “A Study of Tangut Contracts of Employment Excavated in Khara-Khoto" Zhongguo Jingjishi Yanjiu [中國經濟史研究]: Researches in Chinese Economic History, issue $4,2016$. 
Translation and Interpretation of the Contract of Livestock Employment

The format of Livestock Employment Contracts is for the most part similar to that of other contracts in the Tangut period. But unlike contracts of 'absolute sales' such as those of land or livestock sales, whereby the title of the property is transferred entirely from the seller to the buyer, the employment contract sets the terms of a lease for a given period of time. For this reason, the legal language in the narratives of time, penalty fees, and other requirements are usually much more simplified. The following are the translations of 5 pieces of Tangut Contracts of Livestock Employment written in the Tangut script, arranged in chronological order.

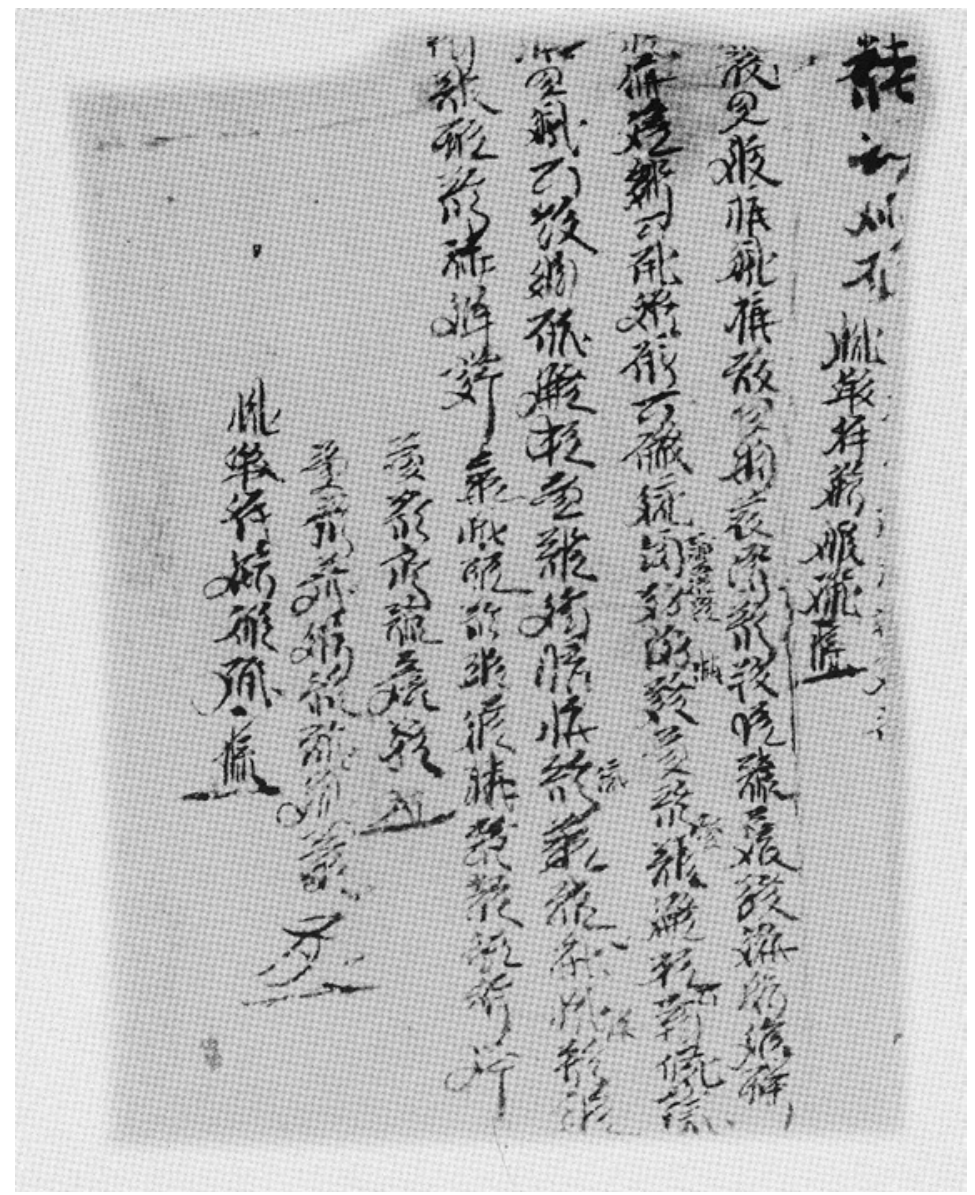

FIGURE 189 Инв. No. 2996-3: Contract of livestock employment for 18 years 
1. The manuscript Инв. No. 2996-3 (Eighteenth Year) Contract of Livestock Employment features 8 lines of Tangut cursive handwritten on an $18.7 \times 13.4$ hemp paper fragment once used as a layering page to a sutra. There are damages on both the upper and lower sections. About 2-3 characters are missing in each line of the upper section. It may be surmised that the contract comes after a few others. The first line of this fragment, with its witness signatures and stamps, seems to be the last of the previous contract. The present document begins only with the second line. It dates the contract to "... eighteenth year, the 28th day of the 2nd month." There are only two 'eighteenth years' in the Tangut chronology: Tiansheng and Qianyou. Therefore, this contract could only have been signed in either the bing-xu 18th year of Tiansheng (1166) or the ding-wei 18th year of Qianyou (1187). Some, if not all of the missing words in the upper section could be inferred from the formulaic language of the law. As usual, the contract ends with stamps and signatures. ${ }^{268}$

Translation:

$\square \square$ year 18 , month 2, day 28, Yehe 'Bore the prosperous' now from Tongpan

?? 'of puppy' voluntarily hires a female mule \& ox; labour price: 1 dan 5 dou.

By 1st day of 8th month, let both livestocks and fees be returned. If overdue,

each dan doubles. Hearts willing. Default penalty in wheat, according to the law. Willing.

Contract Party: Bore the prosperous (蔽莍誁) (stamp)

Co-Contract Party: son? the prosperous iron-head (微获涕) (stamp)

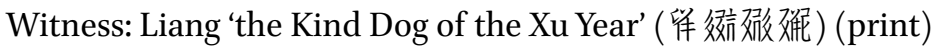

268 Russian Collection of Khara-Khoto Manuscripts, vol. 13, p. 162. 


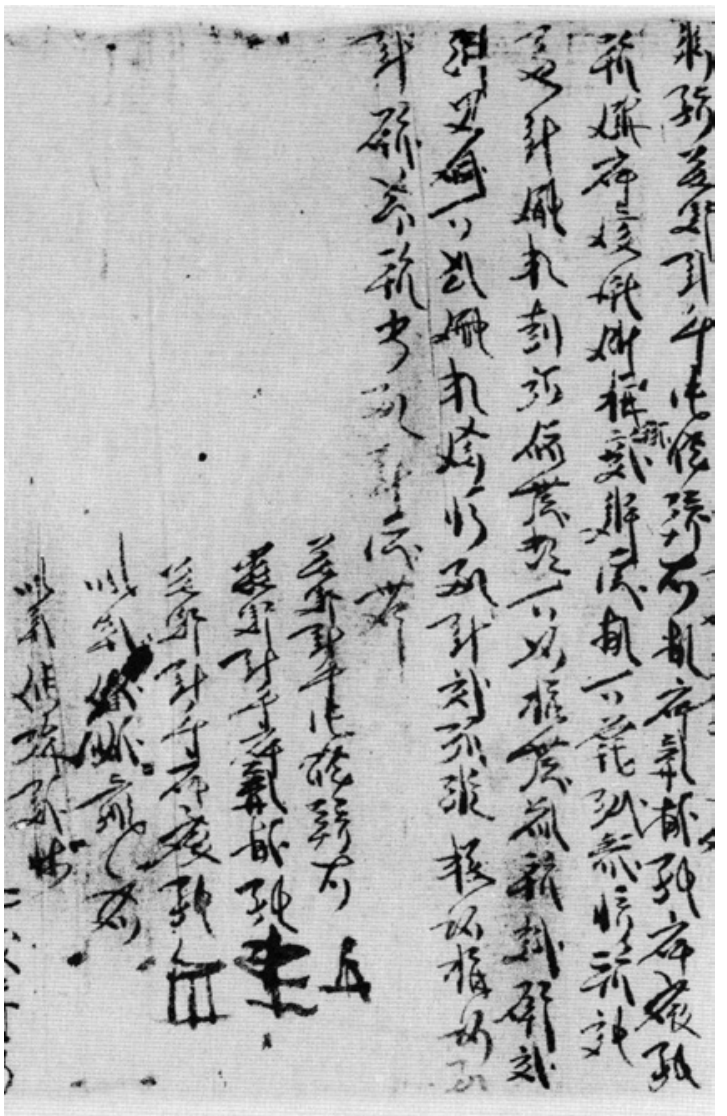

\section{FIGURE 190}

Инв. No. 5124-3(6): Yin year of Tianqing (1194) contract of livestock employment

2. The text Инв. No. 5124-3(6): Yin Year of Tianqing (1194) is included in a long scroll of contracts, three of which are records of livestock employment. It features 10 lines of Tangut in the cursive script, as well as signatures and stamps at the end. ${ }^{269}$

Translation:

On the same day, 浅镸多萃茫 [dzji. rjir dźjiwu dju] and Liang “The Prosperous Iron"

Et al., presently have 稚淩挶 [ljow lja mja]'s 2 cattles and 1 full-teethed black ox

Employed; labour price: 3 dan 5 dou wheat + 1 dan 2 dou coarse grains, agreed.

269 Russian Collection of Khara-Khoto Manuscripts, vol. 14, p. 17. 
By the 1st day of the 8th month, the fee is to be paid; overdue payment doubles.

The livestock is also to be returned. Willing.

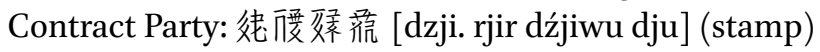

Contract Party: 篗影乘并爱 [ljow zjo. dźjo wejr] (stamp)

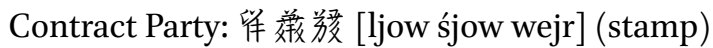

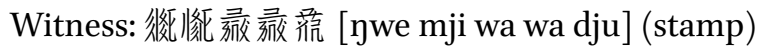

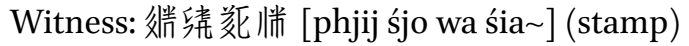

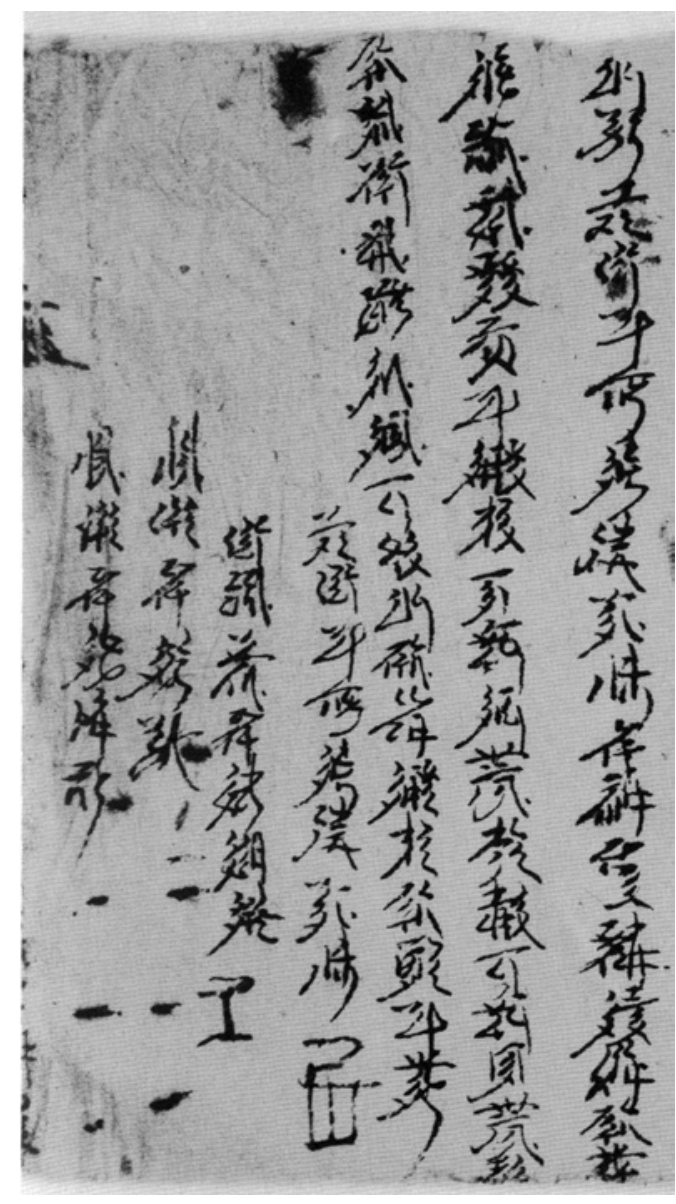

FIGURE 191

Инв. No. 5124-4(4): Yin year of Tianqing (1194) contract of livestock employment

3. The Инв. No. 5124-4(4) Yin Year of Tianqing (1194) Contract of Livestock Employment is the second record of livestock labour in the long scroll of contracts. It features 7 lines of Tangut in the cursive. The text begins with the reference to "the same day" - that is, the same day as the previous contract (a 
contract of livestock sale), signed on the third day of the second month in the Yin Year of Heavenly Celebration. ${ }^{270}$

Translation:

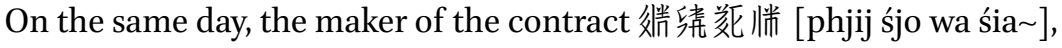

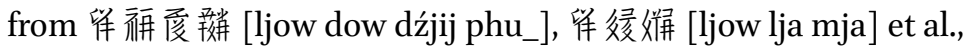

Hires a mare, at the labour price of 1 dan 4 dou of wheat and 1 dan 8 dou of coarse grains,

Terms are agreed upon. By the due date: 1st day of the gth month, the livestock is to be returned, and the fee to be paid. Willing.

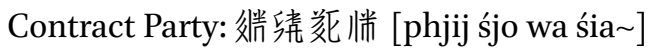

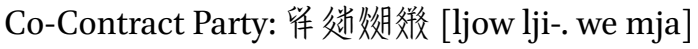

Witness: 留街涕爱 [ljow ne_w wejr]

Witness: 锥父栟務 [ljow da kia ·jiw]

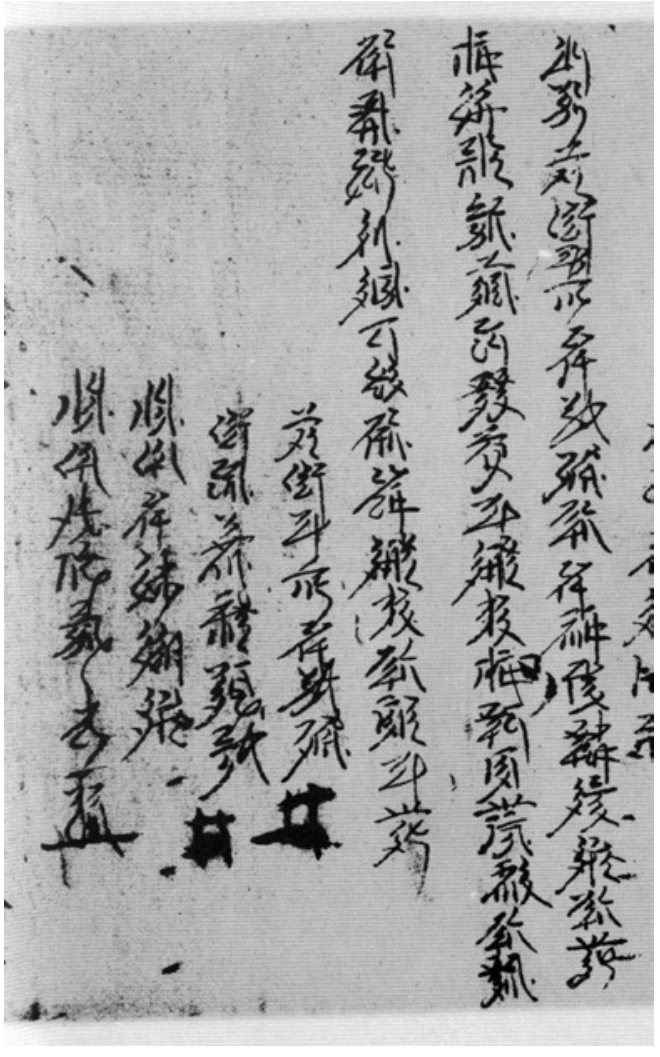

FIGURE 192

Инв. No. 5124-4(5): Yin year of

Tianqing (1194) contract of livestock employment

270 Russian Collection of Khara-Khoto Manuscripts, vol. 14, p. 20. 
4. The Инв. No. 5124-4(5) Yin Year of Tianqing (1194) Contract of Livestock Employment is the third record of animal labour in the scroll of contracts. The text is comprised of 8 lines in cursive Tangut. It, too, begins with the indication of "the same day." In this case, both the two contracts that come immediately before defer to the previous contracts. The next contract further back, a Contract of Livestock Sale, is recorded on the third day of the second month in the Yin Year of Heavenly Celebration. This is, presumably, an accurate dating of the contract with which we are principally concerned in the translation below. 271

Translation:

On the same day, the maker of the contract Liang 鹤嗳 [khjwi- wejr]

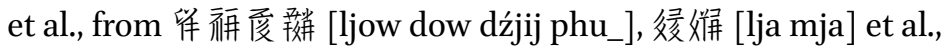

Hires 1 two-teethed male camel, at the labour price of 1 dan 8 dou of coarse grains.

It is agreed upon that by the 1st day of the gth month, the livestocks and the fee are to be returned and repaid. Willing.

Contract Party: 留花嗳 [ljow khjwi- wejr] 'the prosperous dog'

Co-Contract Party: son, 效 嗳 [phə zji] 'the Qiangic'

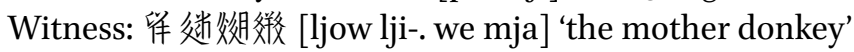

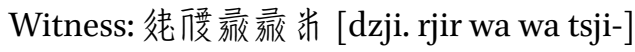

Neither of the three Contracts of Livestock Employment above indicates time in precise terms. All defer to previous contracts by the legal expression "on the same day." The nearest contract accurately dated is the first Contract of Livestock Sale, signed on the 29th Day of 1st Month, in Yin Year of Heavenly Celebration (Tianqing). The second and third contracts are both dated to the 3rd day of the and month, in the same year.

271 Russian Collection of Khara-Khoto Manuscripts, vol. 14, p. 20. 


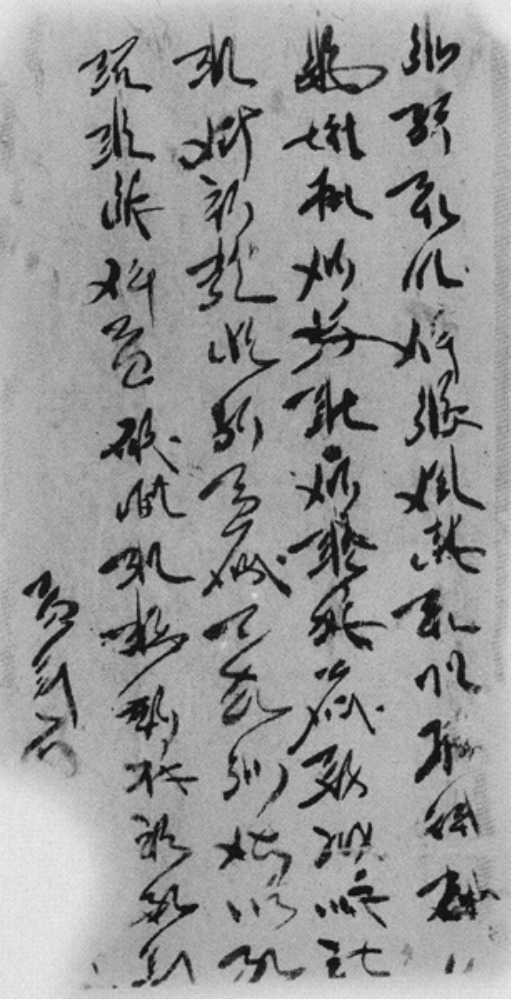

\section{FIGURE 193}

Инв. No. 19-2: Contract of livestock employment

5. Инв. No. 19-2: Contract of Livestock Employment is a manuscript fragment with 5 lines of Tangut cursive handwritten on a $24.2 \times 13 \mathrm{~cm}$ hemp paper, and damages in the lower sections and the back. A few cursive characters remain unidentifiable. ${ }^{272}$

Translation:

On the same day, Yehe 'the joyful at heart' presently from 羓蓄 [·jaxwa $]$ ??, a female cam[

el] and a four vertical[-teethed] four male?? Voluntarily ... hire price: 6 dan of wheat, to be gathered by the 1st day of the 7 th month in the same year. The day

passed, first the hiring fee is to be paid, for each 1 dan, let 2 dan be repaid.

Hirer ...

272 Russian Collection of Khara-Khoto Manuscripts 12, p. 1. 
The long scroll Инв. No. 5124 shows that those who hire animals to perform draft labour in the Contracts of Livestock Employment have in most cases sold their own livestocks. They do so not because they have no need for their service, but to obtain more foodstuff in the short run. Once they are no longer starving, they return to the field, short of animal labour, reduced to the position of hiring animal labour to make up for what they have sold out of urgency and necessity. Surely the peasants might have managed to survive. But there is little doubt that from selling to hiring, they incurred tremendous economic losses that are extremely difficult to recover. They have given up ownership rights to the draft animals - much-valued resources in the agrarian economy.

Take Liang in the Инв. No. 5124-4(4) Contract of Livestock Sale as an example. Immediately after selling his camel and horse in exchange for 2 dan of wheat and 3 dan of coarse grains (roughly 5.6 dan of coarse grains altogether), he hired a two-teethed camel from the Pudu Temple at the price of 1 dan 8 dou of coarse grains. The camel is to be returned, and the fee paid in full by the first day of the ninth month of the year. Clearly, Liang is in need of livestocks. But in between two harvests, short of grains, he has no recourse but to sell his animals to the Pudu Temple, before proceeding to hire another one. Liang lost his two large-sized livestocks. Once the hiring fee is deducted, Liang only receives 3.8 dan of coarse grains for the horse and camel - that is, on average, a low price of no more than 2 dan of coarse grains per animal. A huge loss in incurred in this "selling-and-hiring" process. A similar situation is found in the Инв. No. 5124-4(5) Land Sale Contract. 徯绕 [phjij śjo] sells his two-teethed male camel to the same Pudu Temple in exchange for 2 dan of barley and 1 dan of millet ( 3 dan of coarse grains, in total). Immediately after, he borrows a mare from the Pudu Temple at the price of 1 dan 4 dou of wheat and 1 dan 8 dou of coarse grains (altogether roughly 3.7 dan of coarse grains). After the autumn harvest, 㡓绕 is expected to return the animals along with the fee. But already upon signing the contract, he loses ownership over his own camel. Curiously, it appears that the mare 征绕 [phjij sjo] loans from the Temple is one of the livestocks that Liang had sold to the Temple. And it seems to be the case that the camel Liang ends up borrowing is the one that the Temple purchased from

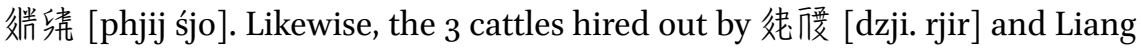
were the exact 3 animals that Weiyi 'the treasure of fortune' had sold to the Pudu Temple on the same day.

The following chart compiles the data on sell and purchase price and employment fee in the 5 Contracts of Livestock Employment and the Contracts of Livestock Sale. Note that where there are more than one kind of grains, I have 
recalculated the amount in the unit of coarse grains, in order to make it easier to compare. (all the register numbers begin with Инв. о..).

CHART 25 Price of livestock sale and employment

\begin{tabular}{llllllll}
\hline Register Time & Hirer & Livestock & Livestock & Hiring \\
owner & hired & fee in & Sell and Price in \\
& & & & & goarse purchase coarse \\
& & & & & grice grains
\end{tabular}

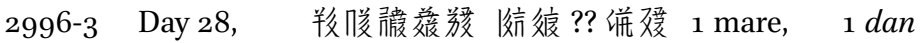

Month 2, [.jaxwa [thow pha 1 usable 5 dou

Year 18 parya wejr] ?? kə ta] cattle

Tongpan

?? 'the

puppy'

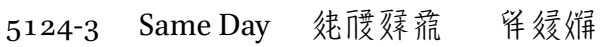

(6) (Year Yin [dzji. rjir [ljow lja

of Tianqing dźjiwu dju] mja]

29th day of \& Liang

1st month "The

(1194) Prosperous

Iron"

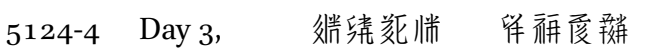

(4) Month 2, [phjij śjo wa [ljow dow

Year Yin of śia ] dźjij phu_],

Tianqing

淩姘 [lja

(1194)

mja], et al.

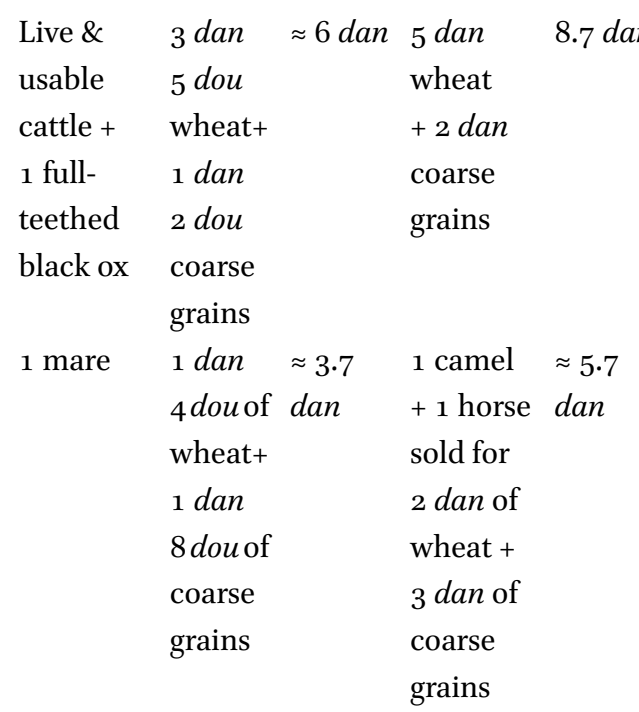

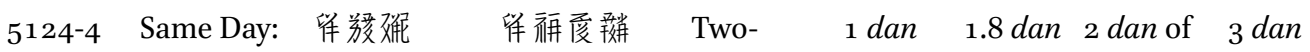

(5) Day 3, [ljow wejr [ljow dow teethed 8 dou of barley +

Month 2 of khjwi-] dźjijphu_], male coarse 1 dan of

Tianqing 徒煸 [lja camel grains millet

(1194) mja]

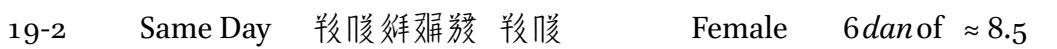

(illegible) [.jaxwa nji_j [.jaxwa] ?? Camel + wheat dan of lji-.jwejr] four- coarse

vertical[- grains

teethed]

4 male?? 
It is not difficult to tell from the three Инв. No. 5124 Livestock Employment Contracts that the cost of hiring animals from spring up to the harvest season in the autumn is more than half of the money earned by selling the livestocks. In other words, the Pudu Temple earns back the cost of purchase within a mere span of two years. Clearly, the monastic establishment there exploited the need of starving peasants suffering the shortage of grain supplies, acquires livestocks en masse at low prices, and loan them back to the peasants deprived of their animals. The temple is able to achieve profit-maximisation in this 'purchase-and-loan' strategy. In two rounds, either two years or even within a year, the temple is able to recover the investments and start making profits, as if they gained the livestocks for free. Therefore, a comparative and connective reading of Livestock Sale contracts, on the one hand, and LivestockEmployment contracts, on the other, reveals the behind-the-scenes financial manipulations of the temples. It also shows that the Pudu Temple, one of the Buddhist temples in the Khara-Khoto area, is deeply engaged in and intertwined with the local economy. It becomes a major owner of land and livestocks, constantly merging, acquiring, expanding, and driving already impoverished peasants onto the path of no return, to bankruptcy and deprivation.

Contracts of exchange are rare in the history of social and legal documents. Some of the Khara-Khoto contracts of exchange are single pages. Others are treated as scratch papers, and bound into a book to transcribe Buddhist sutras on their back. On the other hand, contract of grain loans on livestock mortgage are found either in the single-page format, or in scrolls of papers that feature multiple contracts on the same pages. Both types of contracts are fairly complicated in terms of legal arrangements and social relationships.

\subsection{Exchange Contracts}

A class of Tangut contracts is applied in a particular type of transaction: the exchange of livestocks between two parties. The difference in price is compensated for by the transfer of additional grains. There are specialised legal vocabularies in contracts of exchange. In the manuscript Инв. No. 4195, for instance, the verb used to denote the nature of the transaction is 范 [ywej] (to exchange), and the term, 'to make up for the price difference' is either 级 [lhu] (to add) or 瞆 [khjow] (to pay). Stil, other contracts refer to the action of an owner toward their own livestock as either 跤 [źji.] (to sell) or 船 [lwə] (to purchase), but it is important to take note that in this particular legal context, they are meant to convey the sense of 'exchange,' as well. The force of 'sell and 
purchase' is there, only because one party, whose livestock is in a worse condition, is paying another, who owns a superior animal, to cover the price difference. So, their identities as the 'buyer' and the 'seller' are legal fictions. Surely, there is no reason for why these Contracts of Livestock Exchange cannot be classified as 'Contracts of Livestock Sale.' But they are also clearly much more complicated than simple sell and purchase contracts. Below are the translations of three contracts of livestock exchange with better surviving records of the terms and prices of the exchanges.

\subsubsection{Translation and Interpretation of Livestock Exchange Contract}

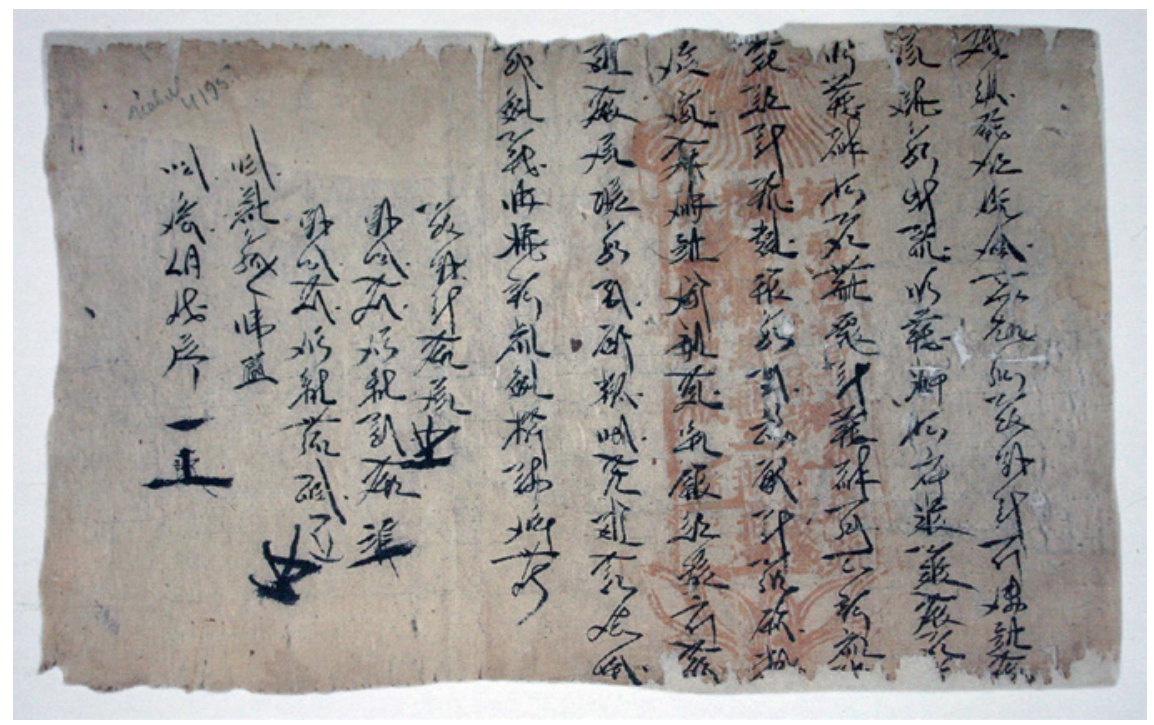

FIGURE 194 Инв. No. 4195: Wu year of Tianqing (1198) contract of livestock exchange

1. Manuscript Инв. No. 4195: Wu Year of Heavenly Celebration (1198 AD) Contract of Livestock Exchange is a single-page contract handwritten on a $23 \times 37.6 \mathrm{~cm}$ hemp paper, with 12 lines of Tangut in the cursive style. The stamping features a lotus imagery, as well as the official $22 \times 7 \mathrm{~cm}$ red seal of the Tangut House of Transactions. ${ }^{273}$

Translation:

On the 1oth day of the 1st month, Wu Year of Heavenly Celebration, Contract Party 情諼爰 [mə zji śjow]

273 Russian Collection of Khara-Khoto Manuscripts, vol. 13, p. 195. 


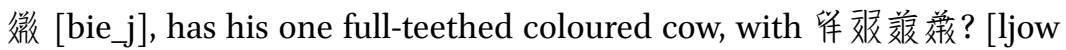
tśju. 'wejr śjow ?]

's full-teethed white cow exchanged. To the white cow is added 1 dan of coarse

grains. The livestocks and grains are delivered, with no debt incurred. If the livestock \& grains

are disputed publically or privately by those in the same chao or others, at that time, 'the joyful iron' is liable. If the direct parties renege on the promise or lie, the penalty is 2 dan of coarse grains. The hearts are willing.

Contract Party: 㧞微 [śjow bie_j], the joyful iron (stamp)

Co-Contract Party: son, 歇举 [lji.j śjow], 'the prosperous iron' (stamp)

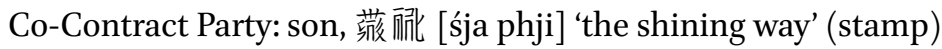

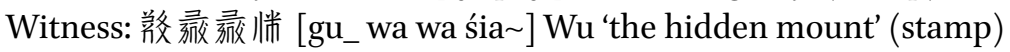

Witness: 呅迌父拼 [zjwi. khjij da kia] Yiqi 'the old house' (print)

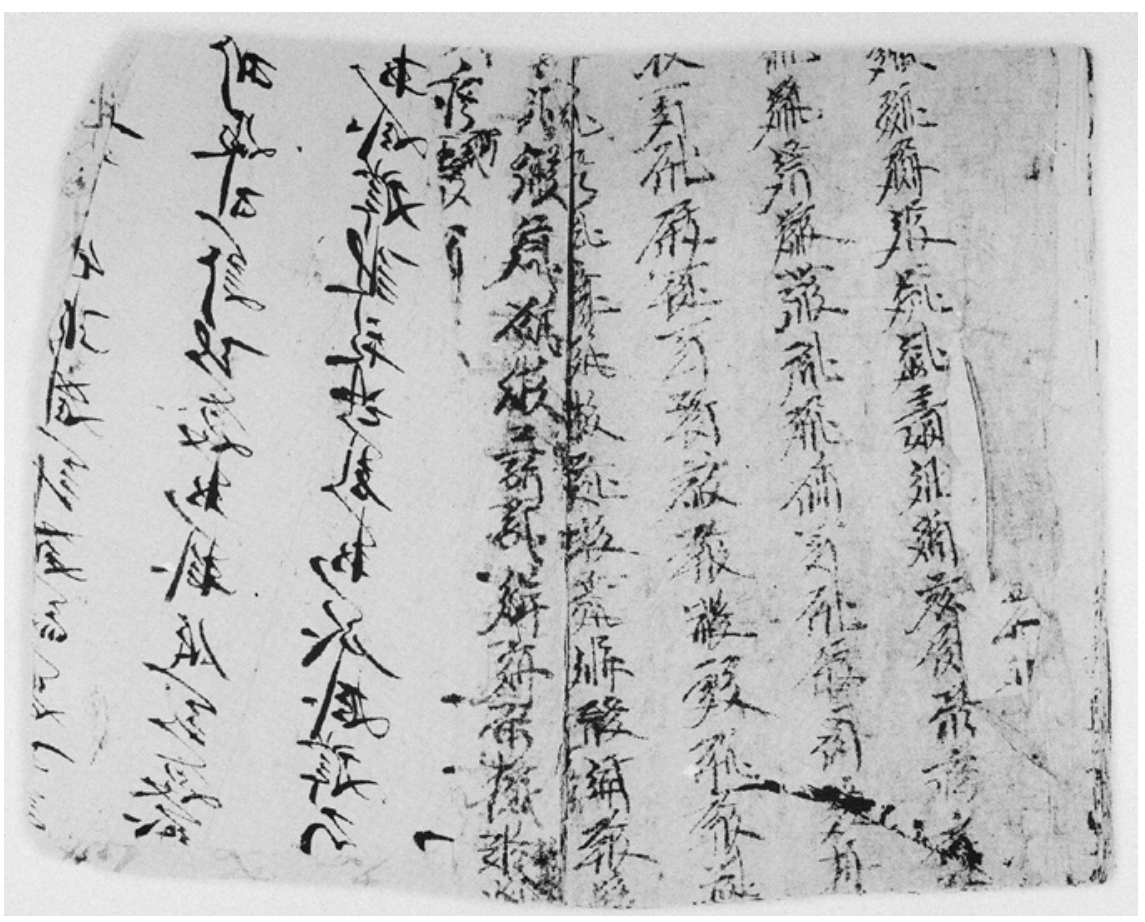

FIGURE 195 Инв. No. 2851-1: Hai year of Tianqing (1203) contract of livestock exchange

2. Инв. No. 2851-1 Hai Year of Tianqing (1203) Contract of Livestock Exchange is a piece of contract found in a volume of books that has been bound by 
discarded contracts. On the back of the pages are scripts of Buddhist sutras. 5 lines of Tangut in the running script are handwritten on a $19.8 \times 25.7 \mathrm{~cm}$ hemp paper, with damages near the end. ${ }^{274}$

Translation:

Hai Year of Tianqing 19 th day of the 1st month, Contract Party Liang ... ? presently purchased from Luwo Xianling's 1 horse, 1 mule ...

Price: to the maroon horse is added 1 dan of coarse grains-paid; re: the

livestocks et al. (no) debt incurred

... and all the concerned parties' affiliates in the same chao, dispute (if there is) ...

?? is liable. If hereafter any party reneges on the terms, the regretting party is to the not-

regretting one (pay) 3 dan ...

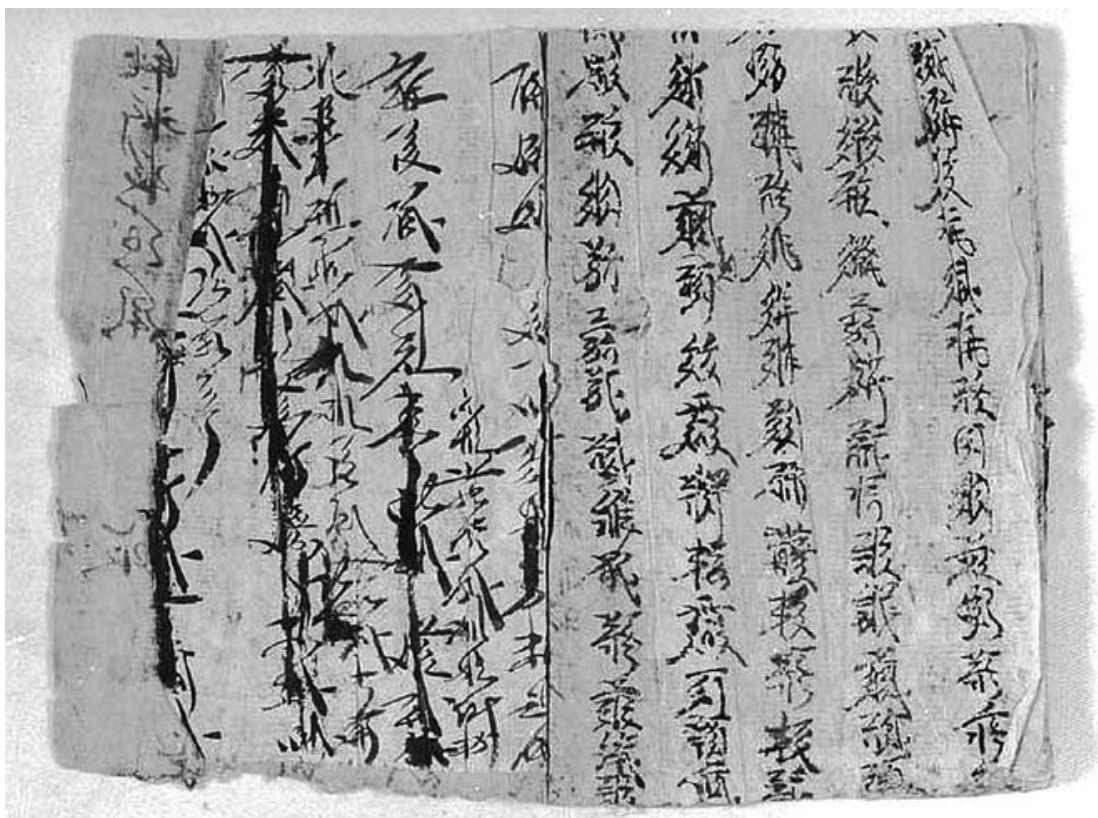

FIGURE 196 Инв. No. 2851-33: Hai year of Tianqing (1203) contract of livestock exchange

3. The manuscript Инв. No. 2851-33 Hai Year of Tianqing (1203) Contract of Livestock Exchange is included in the same volume, handwritten on a $19.8 \times 25.7$

274 Russian Collection of Khara-Khoto Manuscripts, vol. 13, p. 119. 
hemp paper with 5 lines of cursive Tangut, with damages near the end. To the left is another official document. ${ }^{275}$

Translation:

Hai Year of Tianqing, on the 18th day of the 2nd month, the Contract Party?

? 胳獭 [pie. mja ${ }^{276}$ et al., presently have their own full-teethed black male camel

Voluntarily sold to 骰很往婮刻 [-jiw dji.j nji_j lji-.j ywie]; price: 1 fullTeethed male donkey, plus 1 tuo ${ }^{277}$ of coloured coarse cloth, 1 dan 5 dou of coarse grains. One the same day no debt is incurred; if the camel

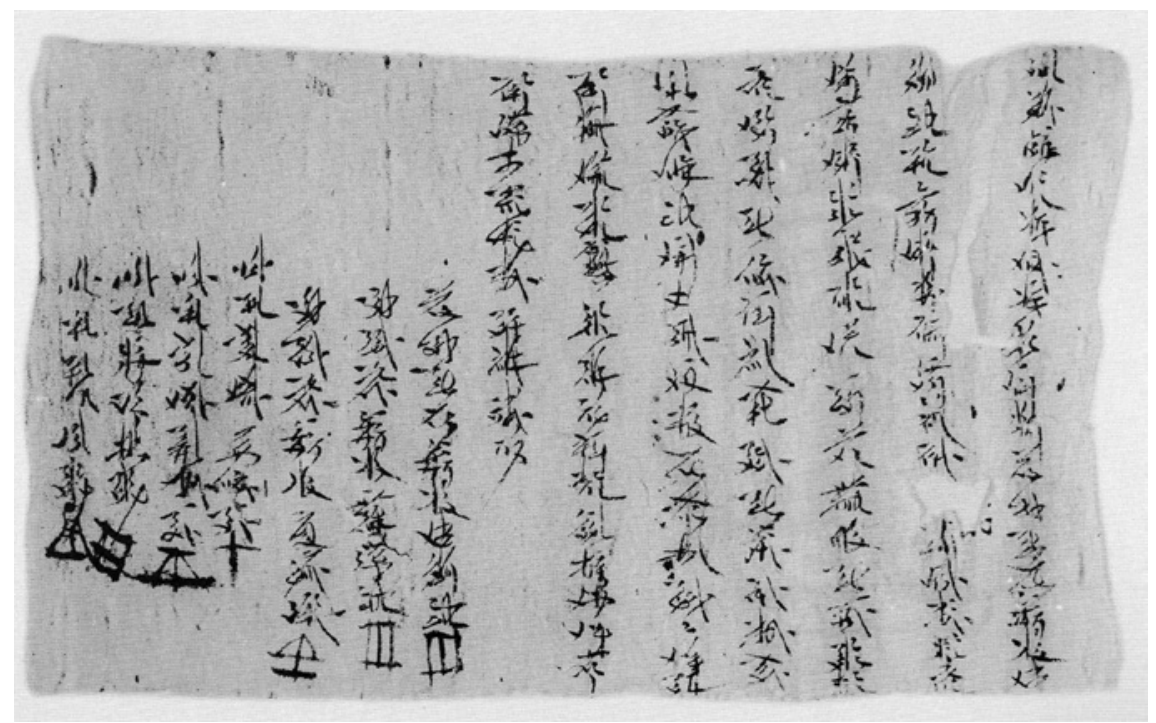

FIGURE 197 Инв. No. 5120-2: Zi year of Tianqing (1204) contract of livestock exchange

4. The Инв. No. 5120-2 Zi Year of Heavenly Celebration (1204) Contract of Livestock Exchange is a single-page contract of 14 lines of cursive Tangut scribed on a $24.3 \times 39.3 \mathrm{~cm}$ hemp paper. The first line dates the contract to

275 Russian Collection of Khara-Khoto Manuscripts, vol. 13, p. 135.

276 TN: lit. "a female frog."

277 TN: Possibly a Tangut equivalent of the Chinese measure unit 度: the length of the distance between two arms stretched out. 
"24th day of the 2nd month, in the Zi Year of Tianqing" (1204). The document also features stamps and signatures. ${ }^{278}$

Translation:

On the 24th day of the 2nd Month in the Zi Year of Heavenly Celebration, Contract Party Mingbu

'the prosperous donkey' et al., have their own one-toothed horse, with 微 粧 [lwər ze] '? kind iron'

's own camel exchanged, on top of which is added?

'the kind iron' has to keep; obtain 5 dan of coarse grains. Re: the horse, if the many

In the same chao dispute over it, and if any party diverges in their wishes, and regret over the terms, the penalty is 10 dan of wheat according to law.

Hearts willing.

The terms in actual circumstances are enforced according to the document.

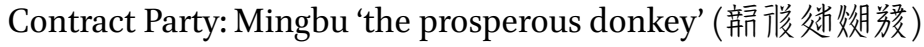

Co-Contract Party: Mingbu 'the greatly prosperous elder' (讋渡舞 满聠)

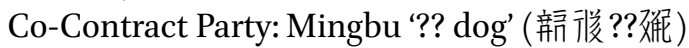

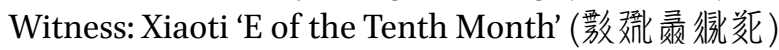

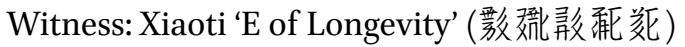

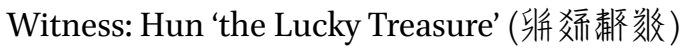

Witness: Yehe 'the Joyful Treasure' (䍪渗微数)

Of the four Contracts of Livestock Exchange presented above, the first is the most complete, and legible. The second and third both suffer the loss of information near the end. The fourth piece is relatively well-preserved, despite missing or blurry characters here and there in the middle.

\subsubsection{Analysis of the Contracts of Livestock Exchange}

Compared to simple contracts of livestock sales, these Contracts of Livestock Exchange differ most crucially in the two parties' voluntary conveyance of titles of livestock properties in their respective domains to each other, resorting to grains to make up for any difference in price and qualities. Therefore, the key points here are the reasons for the exchange at all, and the rate at which grains are transacted to cover price differences.

278 Russian Collection of Khara-Khoto Manuscripts, vol. 14, p. 8. 
In the first transaction - the Contract of Livestock Exchange Инв. No. 4195Moyi offers his own full-teethed coloured cow in exchange for Liang's full-teethed white cow. An additional dan of coarse grains is added to the white cow's end. Although both cows have fully grown their teeth, they are of evidently different prices. The white cow is inferior by 1 dan of coarse grains. But why this consensus on the superiority of the coloured cow to its fellow white bovine? It has been discussed before that large-sized Tangut livestocks are not to be slaughtered at will. Only after dying a natural or otherwise necessary death would the cattles offer their meat to human diet. Therefore, the most likely scenario is that one party initiates the exchange in order to enhance the efficiency of his animal labour. The other side of the negotiation table-the party with the stronger cattle-might have had ample draught labour, but intended to hoard up their grains. They did not simply sell their excellent animal, because they still needed some, if not that much, draft labour. But they are perfectly content with an inferior animal, if only the exchange comes with additional foodstuff. Considering then that these contracts are signed in the interim season between the spring and the autumn, the primary incentive to initiate the exchange could be as simple as the lack of food for daily consumption. As a genre of legal writing, therefore, livestock exchange contracts reflect the historical developments of voluntary economic modulations in the private sphere of the economy. The involved parties obtain what they needed and complemented each other's economic activities. Of course, no transaction is free from defects and inequalities.

It should also be noted that the exchange could only take place in the civil sphere and the private market. That is, only privately-owned animals can be exchanged with other animals in private possession. No personal properties can be used to exchange for government-owned livestocks. The Laws of Heavenly Prosperity is strict in this restriction:

The many are prohibited from exchanging superior and inferior livestocks under government ownership. If such exchange takes place against the law, the price at the time of the exchange is to be calculated. If the values of the livestocks exchanged are equal, let the names be recorded, and those implicated in the exchange be sentenced to one year of imprisonment. If the prices of the livestock are unequal, then let the price difference be recorded, let the charge and sentence be exactly one level below theft. If there is bribery involved, compare it to the charge of corruption, and let whichever is more severe be applied to the criminals. If there is room for discussion, let the sentence be communicated to one level 
below the original charge. Let the original livestocks be returned to their previous possessions. ${ }^{279}$

It is worth noting that not only the exchange of government-owned livestocks is punished severely, up to a year of imprisonment, the sentence is even graver if there is a price difference between the livestocks exchanged. For more intuitive comparisons, see the chart below for the data in the three Contracts of Livestock Exchange.

Compared to sell and purchase, the exchange of livestocks is an economic activity that took place with less frequency, and certainly much more rarely documented in contracts, as well. Thus far, only two contracts of livestock exchange have been identified prior to this period. One was unearthed in Tomb No. 39 in the Astana Cemetery. The manuscript, dated to the nth year of Shengping era in the Former Liang Dynasty ( $367 \mathrm{AD}$ ), records the camel sale by a certain Wang Nian in the Kingdom of Gaochang. In fact, it is a Contract of Livestock Exchange. The text reads:

On Day 15 of the 4th month, 11th year of Shengping, Wang Nian offers his camel

to Zhu Yue, and receives in return a camel; no added exchange: simply left to

right \& right to left. If any of the owners regrets, the penalty is 10 fur carpets

to be offered. Man present at the time: Bo Xianfeng; scriber: Li Daobo; total ...

$(\text { lost })^{280}$

The two concerned parties exchange their camels, with no scheme of compensation to cover the price difference. This is a contract about 670 years earlier than the Khara-Khoto documents. The other surviving piece of livestock exchange contract is the aforementioned contract found in the Dunhuang cave library, concerning an ox-donkey exchange by a monk at the Bao'en Temple.

\footnotetext{
279 Revised Laws of Heavenly Prosperity 19, "On the exchange of government-owned or private livestocks," p. 584.

280 Zhang, Chuanxi, 2014, p. 88.
} 


$\begin{array}{llll}\text { Order Register Time } & \begin{array}{l}\text { Party ini- } \\ \text { tiating the } \\ \text { exchange }\end{array} & \begin{array}{l}\text { Party to with } \\ \text { exchange }\end{array} & \begin{array}{l}\text { Livestock Price in Compensation } \\ \text { exchanged exchange }\end{array} \\ \end{array}$

\begin{tabular}{|c|c|c|c|c|c|c|c|}
\hline 1 & 4195 & $\begin{array}{l}\text { Wu year of } \\
\text { Tianqing } \\
(1198)\end{array}$ & $\begin{array}{l}\text { 情荄举微 } \\
\text { [mə zji śjow } \\
\text { bie_j] }\end{array}$ & 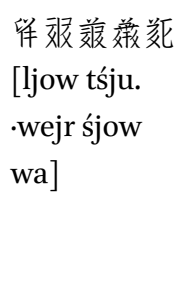 & $\begin{array}{l}1 \text { full- } \\
\text { teethed } \\
\text { coloured } \\
\text { cow }\end{array}$ & $\begin{array}{l}1 \text { full- } \\
\text { teethed } \\
\text { white cow } \\
+1 \text { dan } \\
\text { of coarse } \\
\text { grains }\end{array}$ & $\begin{array}{l}2 \text { dan of coarse } \\
\text { grains }\end{array}$ \\
\hline 2 & $285^{1-1}$ & $\begin{array}{l}\text { Day 19, } \\
\text { month } 1, \\
\text { Hai Year of } \\
\text { Tianqing } \\
(1203)\end{array}$ & $\begin{array}{l}\text { 稚 } \\
\text { [ljow] ... } \\
\text { Liang ... }\end{array}$ & 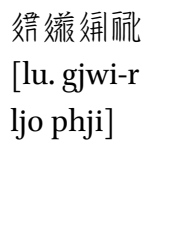 & $\begin{array}{l}1 \text { horse, } \\
1 \text { mule ... }\end{array}$ & $\begin{array}{l}1 \text { maroon } \\
\text { horse }+ \\
1 \text { dan of } \\
\text { coarse } \\
\text { grains }\end{array}$ & 3 dan \\
\hline 3 & $285^{1-33}$ & $\begin{array}{l}\text { Day } 18, \\
\text { Month } 2 \text {, } \\
\text { Hai Year of } \\
\text { Tianqing } \\
(1203)\end{array}$ & $\begin{array}{l}\text { ?? 紧䋛 } \\
\text { [pie. mja] }\end{array}$ & 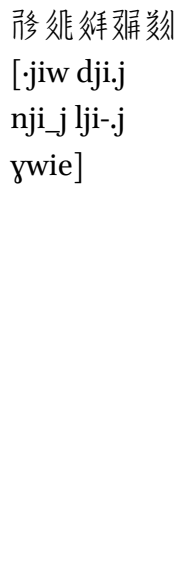 & $\begin{array}{l}\text { Full- } \\
\text { teethed } \\
\text { black male } \\
\text { camel, one }\end{array}$ & $\begin{array}{l}1 \text { Full- } \\
\text { teethed } \\
\text { male } \\
\text { donkey; } \\
\text { coloured } \\
\text { coarse } \\
\text { cloth } \\
1 \text { tuo; } \\
1 \text { dan } \\
5 \text { dou of } \\
\text { coarse } \\
\text { grains }\end{array}$ & \\
\hline 4 & $5^{120-2}$ & $\begin{array}{l}\text { Day 24, } \\
\text { Month 2, } \\
\text { Zi year of } \\
\text { Tianqing } \\
(1204)\end{array}$ & 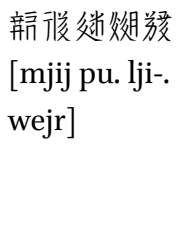 & $\begin{array}{l}\text { 微䉼? 兼 } \\
\text { [lwor ze? } \\
\text { śjow] }\end{array}$ & $\begin{array}{l}\text { One- } \\
\text { teethed } \\
\text { horse }\end{array}$ & $\begin{array}{l}1 \text { camel; } \\
5 \text { dan of } \\
\text { coarse } \\
\text { grains }\end{array}$ & $\begin{array}{l}\text { 10 dan of } \\
\text { wheat }\end{array}$ \\
\hline
\end{tabular}


One Yellow bullock, eight years of age (no seal of purchase $\square$ ) (missing words)

On Day 18, first month of the Yin Year, Bao'en Temple's tenured master, with no ox to use,

$\square$ presently offers a 'green-grass' donkey, seven years of age, and 1 pi of fine cloth, in

Exchange $\square \square \square$ inn $\square \square$ (bullock). The cattle, the donkey, and the cloth, etc.

... (missing end $)^{281}$

In this case, a 7-year-old donkey feeding on green pasture is exchanged for a bullock. The price difference is compensated for by the additional offering of fine cloth. This contract predates the Tangut contracts of livestock exchange by about 370 years.

Thus far, the two documents above are the only livestock exchange contracts that came before the Tanguts. This legal genre is altogether rarely found in the seven or eight hundred years after Western Xia. The fact that up to four Contracts of Livestock Exchange have survived from the Tangut era is most extraordinary.

Obviously, all the 6 contracts of livestock exchange, across 3 different historical periods, have their origins in northwestern China. It seems that there was a long-living tradition of livestock exchange in this area, where pasturing and animal-husbandry has been a major pillar of the economy.

\subsection{Mortgage of Livestock in Grain Loans}

The Khara-Khoto contracts show that some peasants developed the practice of depositing their livestocks as mortgage in order to obtain grain loans. It is a much more complicated legal process than in a simple grain loan contract. Most of these contracts stipulate that the titles of the animals be conveyed to the creditors if the debtor fails to fulfil his financial and legal obligations - the timely repayment of both the principle and the interests-after the autumn harvest. At least 8 pieces of such Contracts of Grain Loan on Livestock Mortgage have been identified in the corpus of Khara-Khoto manuscripts. These legal documents can be further classified in the following ways. Below are the selective translations of these Contracts of Grain Loan on Livestock Mortgage.

281 Dunhuang Economic Documents, p. 35; Zhang, Chuanxi, 2014, p. 207; Chinese Academy of Social Sciences-Institute for History \& British Library (eds.). British Collection of Dunhuang Manuscripts. Chengdu: Sichuan People's Press, 1995, vol. 10, p. 208. 
6.2 .1

Tangut Contracts of Grain Loan on Livestock Mortgage:

Translation and Interpretation

Examples of livestock mortgage contracts include: Инв. No. 2996-1, Инв. No. 4079-1, Инв. No. 4079-2, Инв. o. 4079-3.

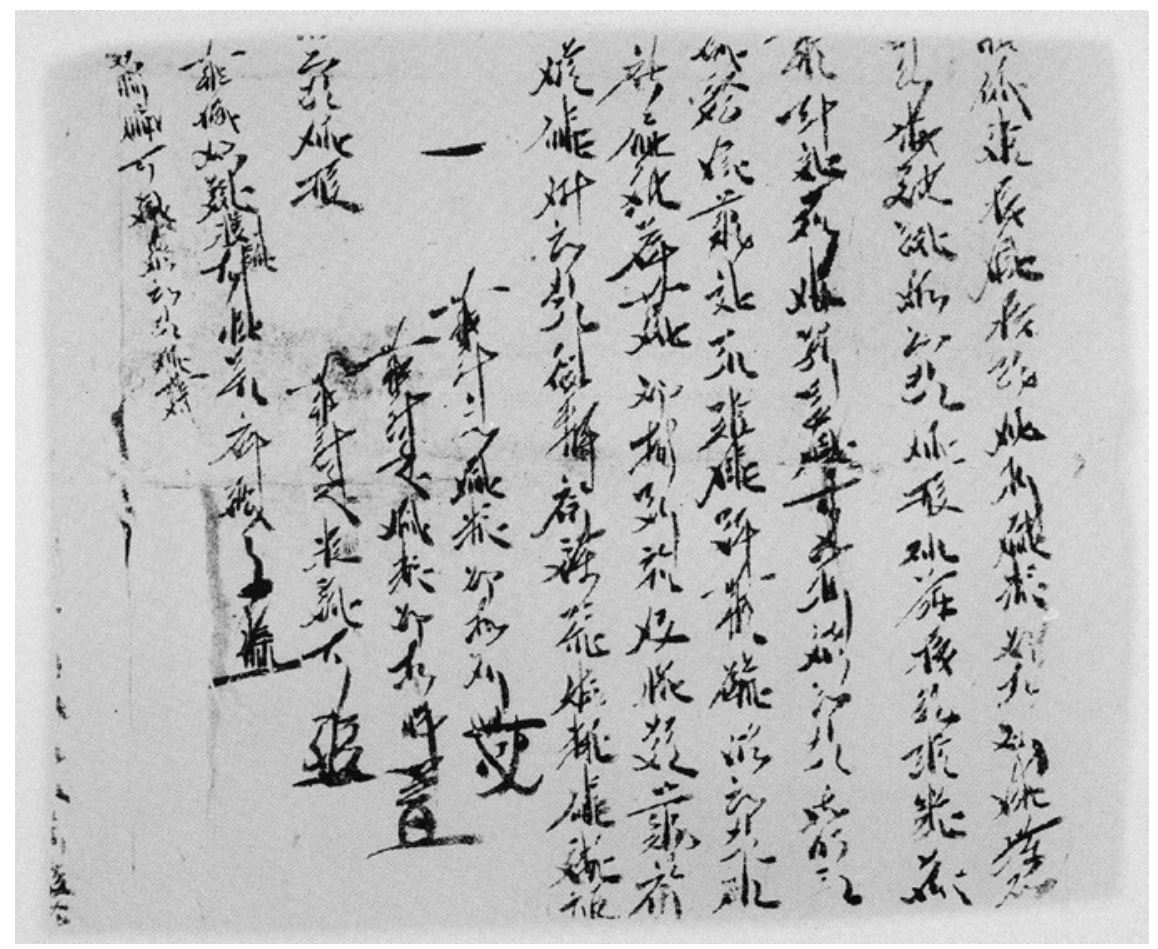

FIGURE 198 Инв. No. 2996-1: Wei year of Tiansheng, contract of grain loan on livestock mortgage

1. The Инв. No. 2996-1 Contract of Grain Loan on Livestock Mortgage in the Year of Wei is a single-page contract handwritten on a $19 \times 23.5 \mathrm{~cm}$ hemp paper that was used as the layering cover of another text. There are 11 lins of Tangut in the cursive script, with some damages on the upper side. Stamps and signatures are found at the end of the contract. What remains of the first line dates the contract to approximately the "... Wei year, twelfth month, twenty-ninth day." The first character that remains somewhat legible, probably the second character of the era title, survives in half, is likely to be 䂦 [lji.j] (prosperous). If so, then the era title is in all likelihood 酸叚 [ywor lji.j] (heavenly prosperity). There are, however, two years of Wei within the Tangut era of Heavenly 
Prosperity: the Third year Xin-wei of Heavenly Prosperity (1151 AD) and the Fifteenth year Gui-wei of Heavenly Prosperity (1163 AD). ${ }^{282}$

Translation:

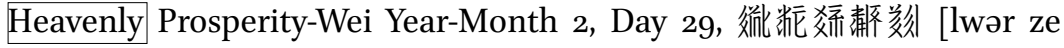
gju_rjur zwie] (Lüyi now from?

? "the puppy" borrows 4 dan of wheat (principle), impawns a two-teethed male camel

By the ist day of the $7^{\text {th }}$ month in the same year, to assemble and repay 6 dan of wheat

? ? overdue, the impawned livestock would cover 6 dan of wheat;

? ? 'the lucky force' et all agreed. If reneges

When the penalty fee according to law is 6 dan of wheat; enforced according to the circumstances and the legal document.

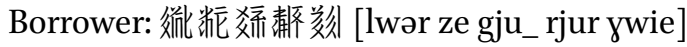

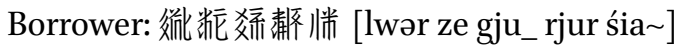

Borrower: 復? [pu. ? dju]

Witness: 傕 [ljow ...]

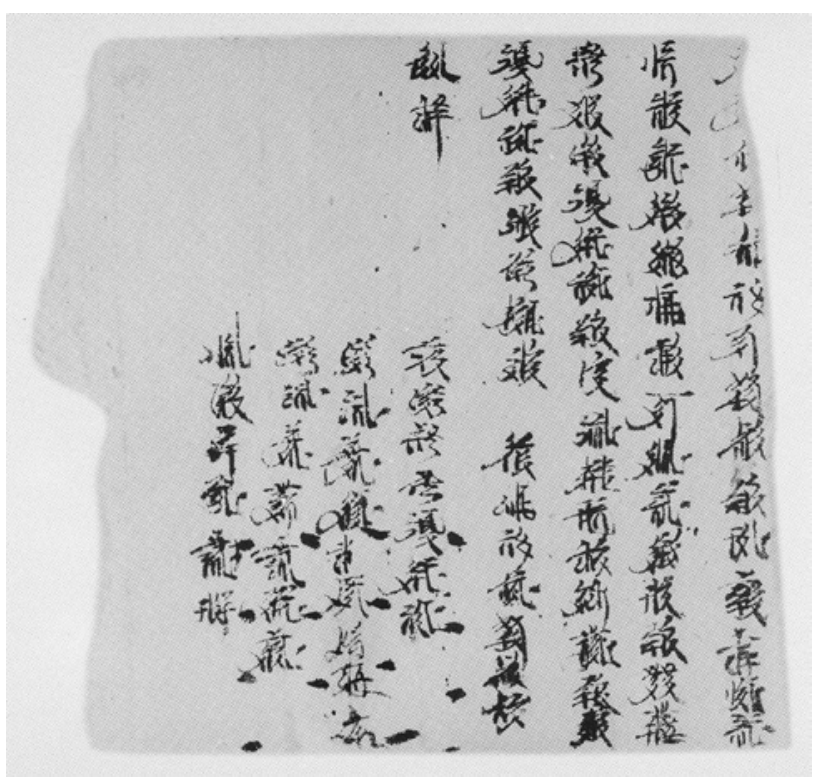

FIGURE 199

Инв. No. 4079-1: Contract of grain loan on livestock mortgage

282 Russian Collection of Khara-Khoto Manuscripts, vol. 13, p. 161. 
2. The Инв. No. 4079-1: Contract of Grain Loan on Livestock Mortgage is a manuscript of 9 lines of cursive Tangut written on a $21.8 \times 22 \mathrm{~cm}$ hemp paper, partially damaged at the front. Both the time and the initial indication of the Contract Parties' names are lost. But the signatures at the end have survived. The stamps are done by finger-marks. ${ }^{283}$

Translation:

?? 5 dan of wheat, 11 dan of coarse grains, loaned; whilst full-teethed Male \& female camels 2, and 1 ?-teethed cow are impawned, Through Intermediaries Jia Laohei et al.; if looted by enemies, Jia Laohei et al. are liable. For default, the penalty according to law is 15 dan of coarse grains

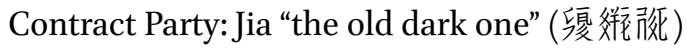

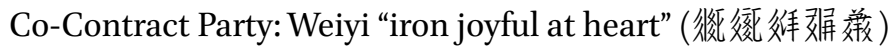

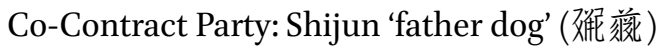

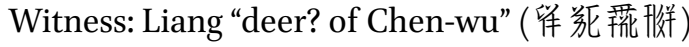

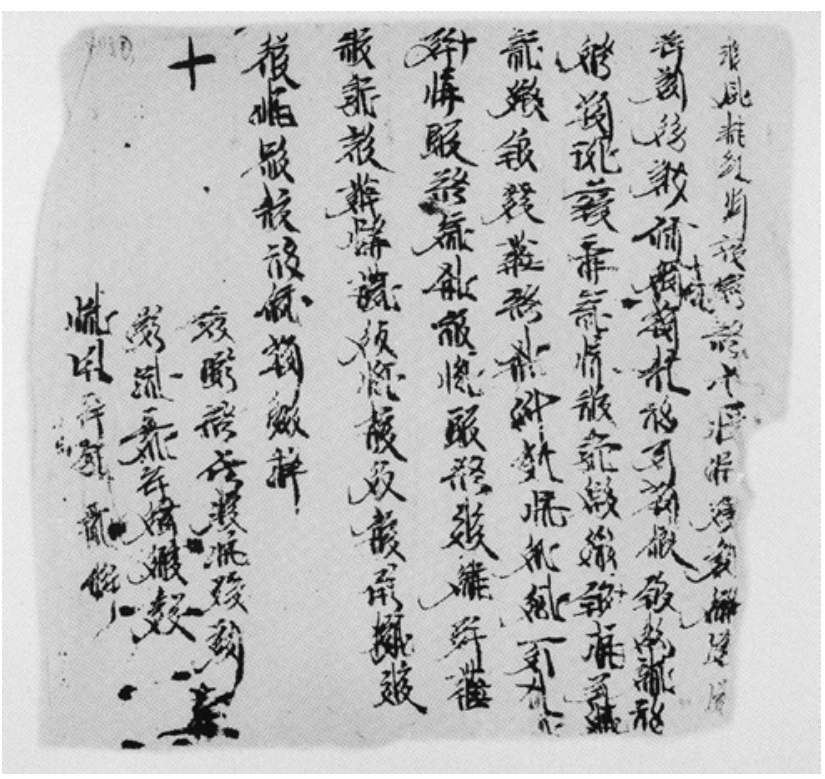

FIGURE 200 Инв. No. 4079-2: Contract of grain loan by pawning livestock

283 Russian Collection of Khara-Khoto Manuscripts, vol. 13, p. 181. 
3. Инв. No. 4079-2 Contract of Grain Loan on Livestock Mortgage is a single-page contract with 10 lines of Tangut in the cursive handwritten on a $22 \times 23 \mathrm{~cm}$ hemp paper. The first line gives away the time as the "third day of the last month." The end of document features signatures and stamps. ${ }^{284}$

Translation:

On the 3rd day of the 12th month, Contract Party 㣪满㯖䊽 [pu. kə ta ywie] first from??

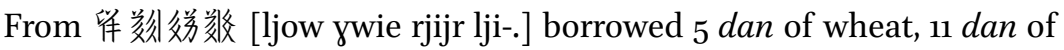
coarse grains

In total 16 dan; 2 full-teethed camel, male \& female, 1 ?

Teethed female camel on mortgage. Due date set on the 1st day of the 9th month

To be repaid. If the payment is overdue, first the impawned

Camels would be seized, with no complaint. In case of dispute or default, The penalty is coarse grains and wheat in 15 dan, according to the law.

Contract Party: 唚垪嫹刻 [pu. kə ta ywie]

Co-Contract Party: Liang Huihuni

Witness: Liang? Chenwu

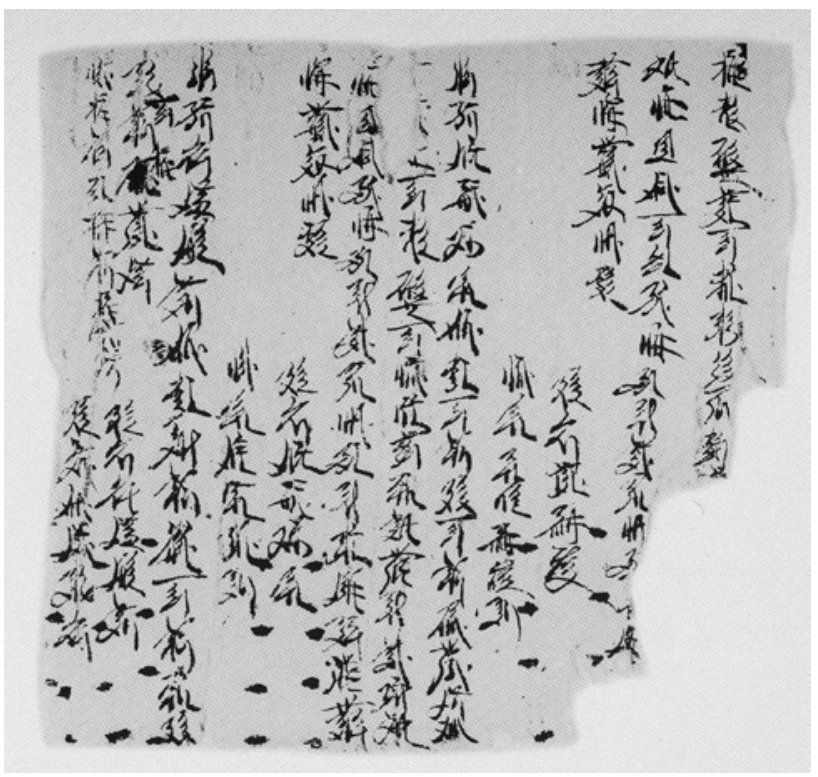

FIGURE 201 Инв. No. 4079-3: Contract of grain loan by pawning livestock

284 Ibid., p. 182. 
4. The document Инв. No. 4079-3: Contract of Grain Loan on Livestock Mortgage is a roll of serial contracts. Three texts remain legible, where 15 lines of Tangut cursive are handwritten on a $22 \times 23 \mathrm{~cm}$ hemp paper, followed by signatures and finger-stamps. ${ }^{285}$

The first document suffers some damage at the beginning, but the second and third are basically intact. The following is a translation of the second contract.

Translation:

On the same day, 㣭龍栟较 [mə dzow gju_dzjwo] (Mozang "the lucky man") borrows 1 dan of wheat; the principle is increased to 1 dan 5 dou, on the mortgage of 1 roll of fur carpet, 1 sheep. By the date agreed upon,

before August, the sum must be repaid. In case of overdue payment, first to cover the debt

The [mortage] is seized. There is no disagreement.

Borrower: 捘龍㸚搬 [mə dzow gju_dzjwo]

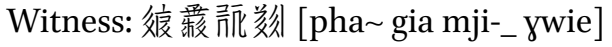

Here, the mortgage is comprised of not only animals but also a roll of fur carpet.

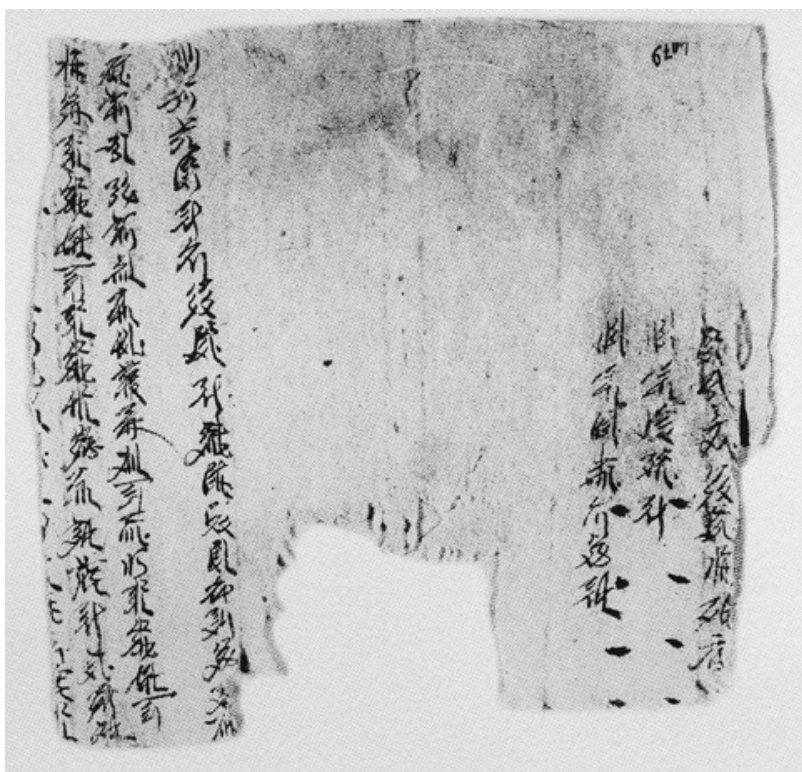

FIGURE 202 Инв. No. 4079-4: Contract of grain loan on livestock mortgage

285 Ibid., p. 182. 
5. The document Инв. No. 4079-4: Contract of Grain Loan on Livestock Mortgage is a $22.2 \times 23 \mathrm{~cm}$ manuscript on hemp paper, partially damaged. It features 7 lines of Tangut in the cursive. Two pieces of contract are patched into one. The first 3 lines are in fact the signatures lingering from the previous contract. The last 4 lines are the first half of another contract. In the last line, in particular, only the half of the characters - the strokes on the right-have survived. ${ }^{286}$

Translation:

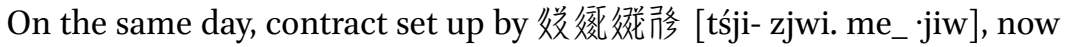
from the official 锥䊽姘 [ljow ywie rjijr]?

Borrowed 5 dan of wheat, 10 dan of coarse grains, and have 1 full-teethed female camel, 1

2 vertical (teethed) female camels, 1 tamed male camel mortgaged. Date?

A few other documents, such as the Инв. No. 4079-5 and the 4079-6, all belong to this genre of contract of grain Loan on Livestock mortgage.

There is yet another piece of grain loan contract on mortgage that is even more peculiar and complex. The Or.12380-0023 (K.K.IIO283.t) grain loan account, now in Britain, is written on a piece of $19 \times 18.5$ white hemp paper. It has 11 lines of Tangut in the cursive script. ${ }^{287}$ The debtor wishes to take out a loan of 7 dan of wheat, 4 dan of barley, as well as 4 dan of millet. If he fails to repay the debt in full by the first day of the seventh month, then the title of not only camels, but also a shijun would be conveyed to the creditor. Thus far, this is the only loan contract whereby both livestocks and living human beings are deposited in the mortgage. Likewise, it is a rare find also in the history of mortgage and transactions of human beings in ancient China. It is also an example of 'real contract': obligatio quae re contrahitur, in the history of Chinese contracts.

\subsubsection{Analysis of the Contracts of Grain Loan on Livestock Mortgage}

The Tangut Contracts of Grain Loan by Pawning Livestock are similar to simple grain loan contracts in two key aspects of the legal documents: the creditors charge interests, asking for the return of not only the principle but also the profits at the end of the term. Also, it is the same in both cases that, overdue payments are penalised with a fee, also in terms of grains. One could not but

286 Ibid.

287 British Collection of Khara-Khoto Manuscripts, vol. 1, p. 11. 


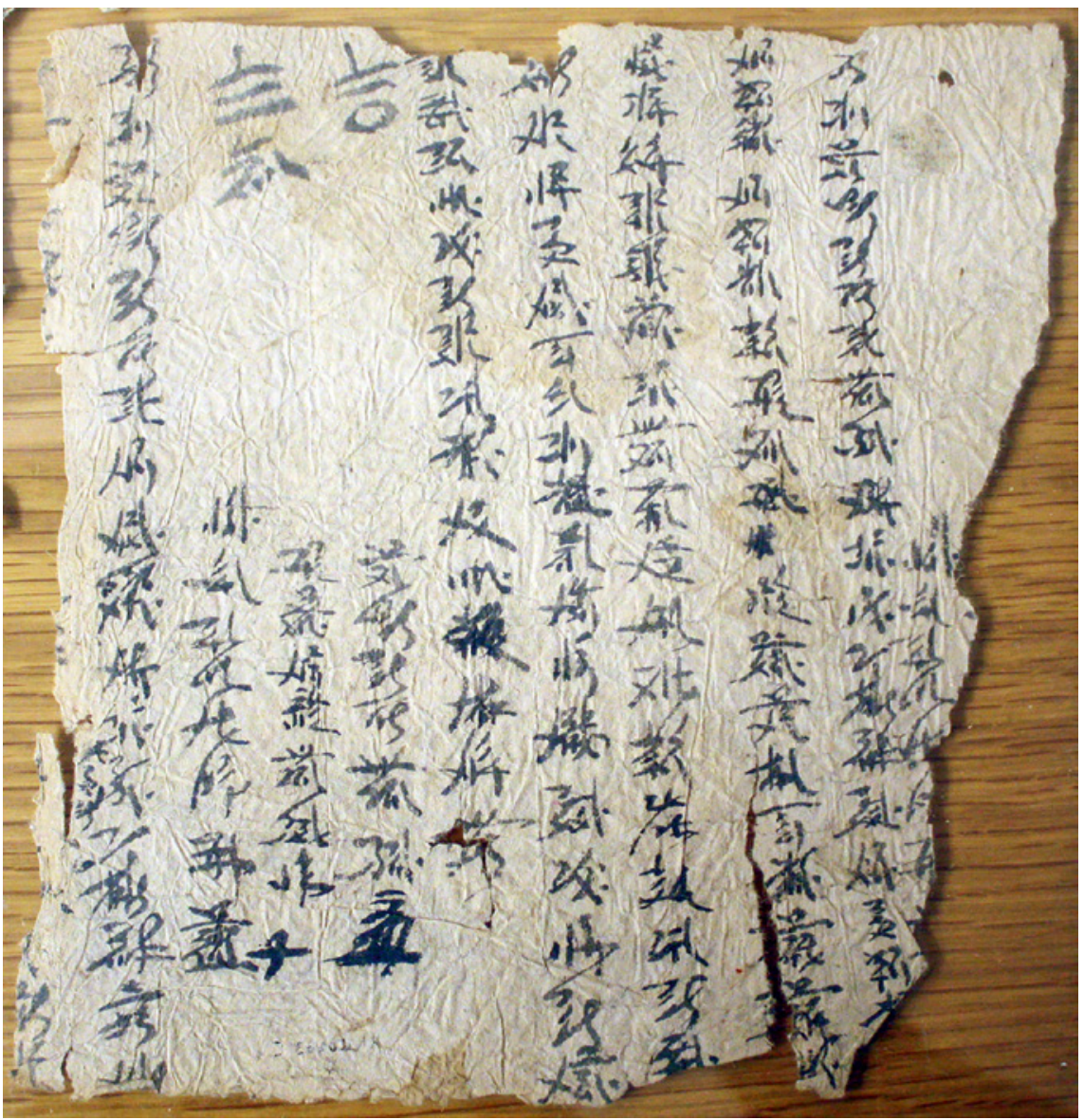

FIGURE 203 British Manuscript Or.12380-0023 (K.K.IIo283.t): Contract of grain loan on livestock and human mortgage

wonder how the defaulter could be realistically expected to be able to muster more grains to pay the penalty fee if he fell short of the original sum. The Contracts of Grain Loan on Livestock Mortgage, however, differ form simple grain loan contracts in one key aspect: the borrower has deposited his livestocks as a security upon the signing of the lease. In case of overdue payment or default, the loaners could simply claim the property as their own, according to the terms set in the contract. This form of loan provides a much greater sense of financial security for the creditors. In the document Инв. No. 2996-1: Contract of Grain Loan by Pawning Livestock in the Year of Wei, the debtor deposited a mortgage of a two-teethed male camel in order to take out a loan of 4 dan of wheat. When the harvest season comes in the autumn, he is expected 
to pay 6 dan of wheat, at the same interest rate of $50 \%$ as in most simple grain loan contracts that we have so far seen. In case of an overdue payment, the creditor may seize the camels to cover the loss. But if the debtor reneges on his obligations altogether, the penalty is another 6 dan of wheat.

Because the document Инв. No. 4079-1: Contract of Grain Loan on Livestock Mortgage, has a missing first line, there is no reliable way to establish its date or to identify the contracting parties involved. But near the end, the signatures reveal the main Contract Party as Jia Laohei, who borrowed 5 dan of wheat and 11 dan of coarse grains, on the condition of depositing 2 camels and 1 cow as mortgage. From the text itself, it seems to be the case that the livestocks are still kept by the debtor, rather than transferred to the guardianship of the creditor, for the time being. So, they are not technically a 'security deposit' in the hands of the loaner. That is why the contract also hypothesises a scenario most intriguing, that if the animals are looted and fall into the dominion of foreign enemies, it is Jia Laohei, the borrower, who bears liability. In addition, the agreement stipulates that in case of default, the debtor pays a penalty fee of 15 dan of grains.

The curious reference to the legal complications whereby the camels are looted by the enemies is rarely seen elsewhere in historical contracts. It shows, first of all, that the livestocks were in constant danger of being seized in plunders and pillages. It would not be added into the contract as a clause in peace times. So, although we are still unsure of the precise dating of the contract, it is quite likely that it was signed at a time when the border city of Khara-Khoto was menaced by Mongol arms - that is, toward the end of the Tangut Empire.

A certain co-Contract Party by the name of Shijun Quanfu also signed at the end of the contract. The identity of the man concerned is labelled as Shijun. It is known, of course, that the shijuns constituted a special class of lowly serfs who were legally transacted by their masters. Therefore, the presence of a shijun, as a legal persona in the role of the co-Contract Party, is most noteworthy. It shows that, quite possibly, the shijuns had by this period of time achieved a certain kind of legal status in the Tangut society by this period of time. However, it must also be noted that although they are able to perform legal duties as self-owning civilians, the mark of their historically lower status is not altogether easy to erase. That is perhaps why the label "shijun" has to be bound up with the name.

In the document Инв. No. 4079-2: Contract of Grain Loan on Livestock Mortgage, the Contract Party is the pawner Bu who takes out a loan of 5 dan of wheat and 11 dan of coarse grains from Liang, on a mortgage of livestock. In case of overdue payment, the creditor is legally authorised to appropriate these camels. But if the debtor reneges on his commitments, then the penalty 
would be 15 dan of grains. Near the end of the contract, one finds the names of not only $\mathrm{Mr}$. Bu, but also two other co-Contract Parties. One of them is Liang Huihuni. Huihu (邊䑃) is, of course, also the name of the ethnic Huihu folk. Of course, a sizeable Huihu population lived in the Tangut dominion, whilst other Huihu tribes bordered Western Xia as neighbours. Curiously, "Huihu" is listed as a "Fan name" in the Assorted Words. It is well possible that here, the man named Liang Huihuni might have had ethnic Huihu heritage.

Below is a chart that offers a more visual representation of the data in Tangut contracts of grain loans and livestock mortgages:

CHART 27 Data in Tangut contracts of grain loans and livestock mortgages

\begin{tabular}{|c|c|c|c|c|c|c|c|}
\hline Register & Date & Pawner & Loaner & $\begin{array}{l}\text { Livestock } \\
\text { mortgaged }\end{array}$ & $\begin{array}{l}\text { Grain } \\
\text { loan }\end{array}$ & $\begin{array}{l}\text { Overdue } \\
\text { payment }\end{array}$ & $\begin{array}{l}\text { Default } \\
\text { penalty }\end{array}$ \\
\hline 2996-1 & $\begin{array}{l}\text { Wei Year: } \\
\text { Contract } \\
\text { of Grain } \\
\text { Loan by } \\
\text { Pawning } \\
\text { Livestock }\end{array}$ & 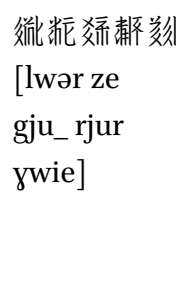 & $\begin{array}{l}\text { ?? 垪砕 } \\
\text { [?? kə ta] }\end{array}$ & $\begin{array}{l}\text { Two-teethed } \\
\text { male camel }\end{array}$ & $\begin{array}{l}\text { Wheat } \\
6 \text { dan }\end{array}$ & $\begin{array}{l}\text { Loaned } \\
\text { livestock } \\
\text { covers } \\
6 \text { dan of } \\
\text { wheat }\end{array}$ & $\begin{array}{l}6 \text { dan of } \\
\text { wheat }\end{array}$ \\
\hline $4079^{-1}$ & & & & $\begin{array}{l}2 \text { full-teethed } \\
\text { male \& } \\
\text { female } \\
\text { camels, and } \\
1 \text { ? teeth cow }\end{array}$ & $\begin{array}{l}\text { Wheat } \\
5 \text { dan; } \\
\text { coarse } \\
\text { grains: } \\
11 \text { dan }\end{array}$ & & $\begin{array}{l}15 \text { dan } \\
\text { ofcoarse } \\
\text { grains }\end{array}$ \\
\hline $4079^{-2}$ & $\begin{array}{l}\text { Third day } \\
\text { of the last } \\
\text { month: } \\
\text { Contract } \\
\text { of Grain } \\
\text { Loan by } \\
\text { Pawning } \\
\text { Livestock }\end{array}$ & $\begin{array}{l}\text { 行垪硣垓 } \\
\text { [pu. kə ta } \\
\text { Jwie] }\end{array}$ & 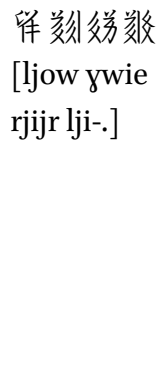 & $\begin{array}{l}2 \text { full-teethed } \\
\text { male \& } \\
\text { female } \\
\text { camels, } 1 \text { ? } \\
\text { tooth-camel }\end{array}$ & $\begin{array}{l}\text { Wheat: } \\
5 \text { dan; } \\
\text { coarse } \\
\text { grains } \\
11 \text { dan }\end{array}$ & $\begin{array}{l}\text { Pawned } \\
\text { camels }\end{array}$ & $\begin{array}{l}\text { Coarse } \\
\text { grains \& } \\
\text { wheat: } \\
15 \text { dan }\end{array}$ \\
\hline $4079-3$ & $\begin{array}{l}\text { Same Day: } \\
\text { Contract } \\
\text { of Grain } \\
\text { Loan by } \\
\text { Pawning } \\
\text { Livestock }\end{array}$ & 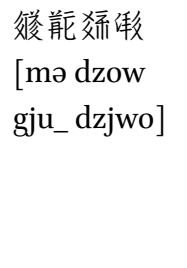 & & $\begin{array}{l}1 \text { cattle, } \\
1 \text { sheep, as } \\
\text { security for } \\
\text { loan }\end{array}$ & $\begin{array}{l}\text { Wheat: } \\
1 \text { dan; } \\
\text { to pay } \\
1 \text { dan } \\
\& 5 \text { dou }\end{array}$ & $\begin{array}{l}\text { To be } \\
\text { seized } \\
\text { to cover } \\
\text { the debt }\end{array}$ & \\
\hline
\end{tabular}


CHART 27 Data in Tangut contracts of grain loans and livestock mortgages (cont.)

\begin{tabular}{lllllll}
\hline Register Date & Pawner & Loaner & $\begin{array}{l}\text { Livestock } \\
\text { mortgaged }\end{array}$ & $\begin{array}{l}\text { Grain } \\
\text { loan }\end{array}$ & $\begin{array}{l}\text { Overdue Default } \\
\text { payment }\end{array}$ & \begin{tabular}{l} 
penalty \\
\hline
\end{tabular} \\
\hline
\end{tabular}

\begin{tabular}{|c|c|c|c|c|c|}
\hline \multirow[t]{6}{*}{$4079-4$} & Same Day: & 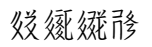 & 留刻㴚 & Full-teethed & Wheat: \\
\hline & Contract & [tśji- zjwi. & [ljow ywie & female camel; & 5 dan; \\
\hline & of Grain & $\left.\mathrm{me}_{-} \cdot \mathrm{jiw}\right]$ & rjijr] & 1 two-vertical & coarse \\
\hline & Loan by & & & (teeth) female & grain \\
\hline & Pawning & & & camel; 1 male & 10 dan \\
\hline & Livestock & & & camel & \\
\hline
\end{tabular}

\section{$7 \quad$ Communal Contracts}

Societies are a unit of organised community in the civil sphere and at the base level of ancient Chinese societies. Societal organisations have a long history that dates back to pre-Qin eras. They reached unprecedented heights of prosperity in the Tang, the Five Dynasties, and the Song periods. As a primary source, the communal contracts are documents that reflect the content of the historical communal activities. The vivid details contained in these materials are of tremendous historical value. A batch of such documents have been found in the Dunhuang library cave. Since then, Dunhuangologists have conducted systematic studies of these materials, prepared full transcriptions, and published academic literatures on some of the contracts. ${ }^{288}$ Amongst them are about 20 or so communal 'charters' or 'constitutions' that enumerate the bylaws and the terms of agreements, designed for the better orgnaisation of these societies. Of these, 10 are official documents, most of which are fragments, whereas others seem to be drafts, copies, and duplicates. The corpus of Khara-Khoto communal contracts, on the other, boast some of the more complete official documents that are of especially great value.

\subsection{Format and Content of Communal Contracts}

So far, two charter-style communal contracts have been identified in the midst of Khara-Khoto manuscripts. They are called 'societies of the many' in Tangut. Although essentially a charter of rules and regulation for the

288 Ning and Hao, 1997. 
internal governance of the organisations, such documents are legally binding. Therefore, they may be styled as "Communal Contracts."

\subsubsection{The Translation and Interpretation of Communal Contracts}

The two Tangut Communal Contracts referred to above are the Инв. No. 594931: "Communal Contract in the Yin Year of Guangding (1218)" and the No. 7879 Communal Contract. Both contracts are written in cursive Tangut. In addition to paleographic and calligraphic complexities, the text is not in its optimal state of legibility. Therefore, it is impossible to speak of a high level of confidence in any effort to read, translate, and interpret. For the time being, many questions remain to be tackled. The No. 7879 Communal Contract, in particular, suffers significant loss and damage. Due to poor legibility, it is extremely difficult to sew individual characters into sensible sentences. Therefore, only a literal transcription into Chinese characters is provided in the notes.

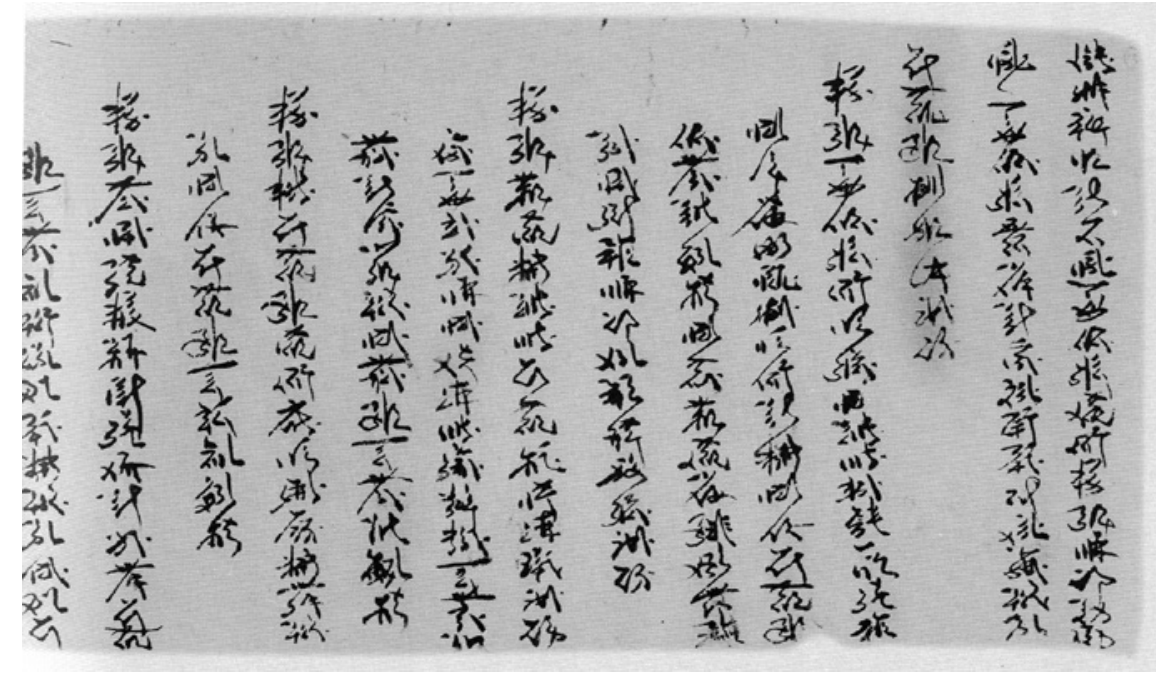

FIGURE 204 Инв. No. 5949-31: Yin year of Guangding (1218) communal contract (1) Note: TN: The manuscript No. is not 7879 . 


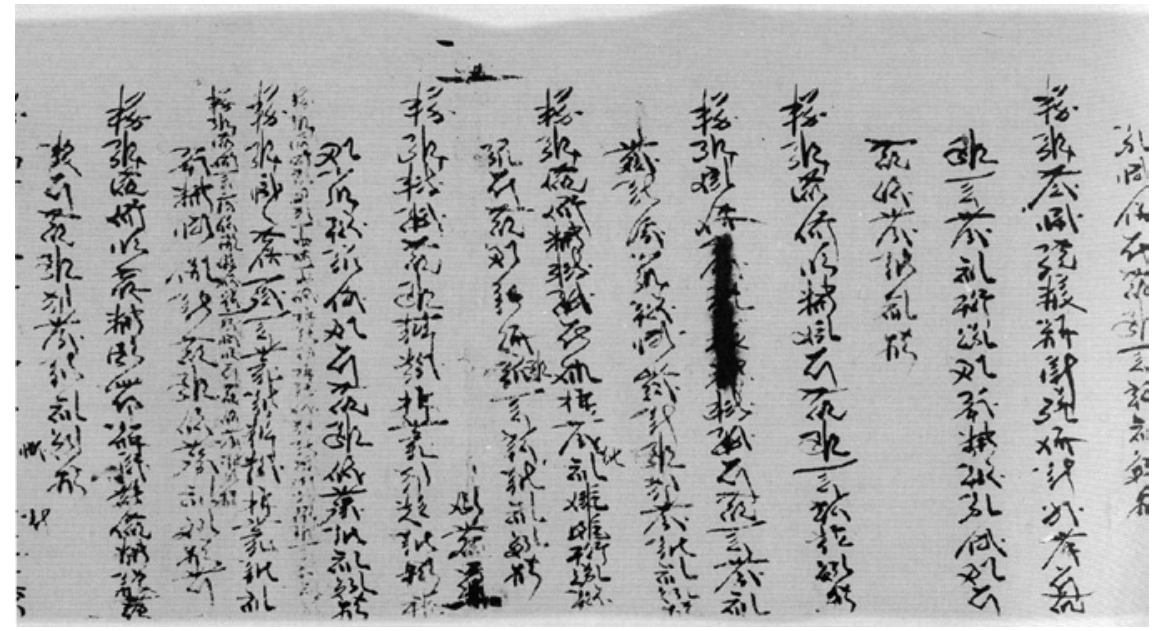

FIGURE 205 Инв. No. 5949-31: Yin year of Guangding (1218) communal contract (2)

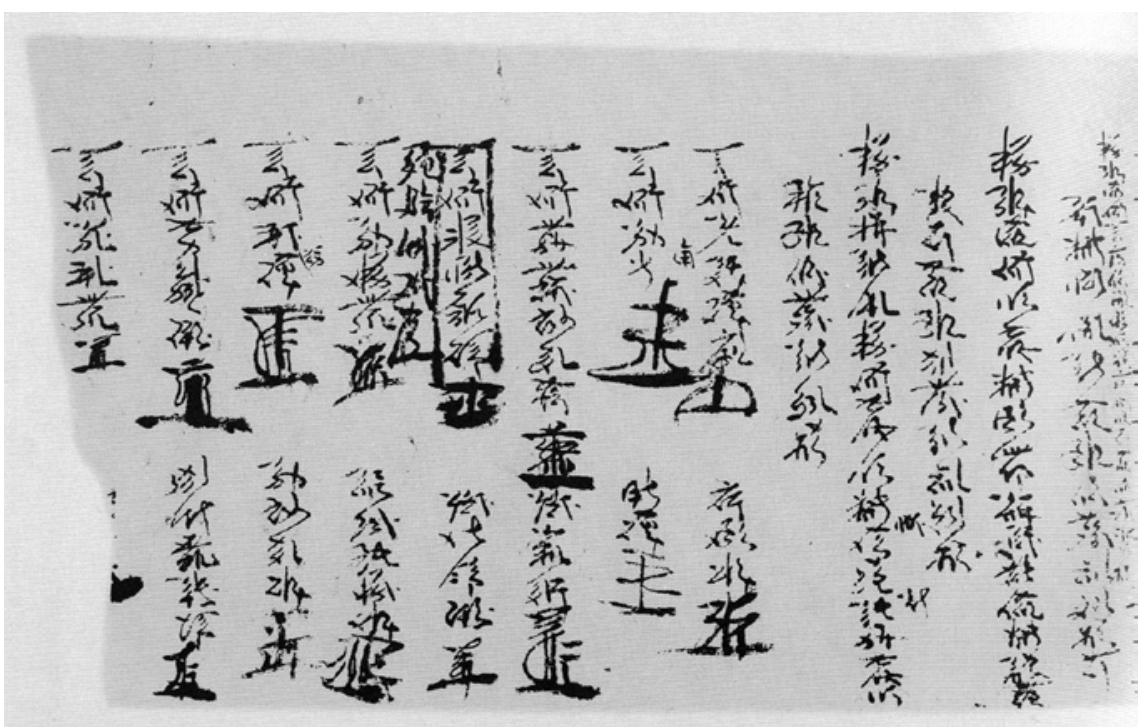

FIGURE 206 Инв. No. 5949-31: Yin year of Guangding (1218) communal contract (3)

1. The Инв. No. $5949-31$ Communal Contract is a long, $19.4 \times 90.2 \mathrm{~cm}$ scroll handwritten on hemp paper, with 40 lines of writings in cursive Tangut. The first line reads, "Guangding, Year of Yin, eleventh month, fifteenth day" - that is, the year of $1218 \mathrm{AD}$. The contract is signed and stamped, and there are traces of edits and erasures in the manuscript. ${ }^{289}$ The handwriting in this manuscript

289 Russian Collection of Khara-Khoto Manuscripts, vol. 14, pp. 92-93. 
is highly cursive, supplemented by occasional appearances of running-script writings in a smaller font, which are even harder to identify.

Translation:

On the 15th day of the 11th month, in the Yin Year of the Guangding era, a society is established, whereby its members voluntarily agree to

gather on the 15th day of each month, hereupon discussed and decided.

The first ceremony?

the persons at the time are to implement the following terms:

One item: concerning the gathering on the $15^{\text {th }}$ day, unless ill or in long-distance travel,

(with these exceptions), if members are slack or absent in attending the gathering,

They are not only punished 5 dou, the many? to go engage in merit-making?

the place of the various bureaus? should? proceed to implement.

One item: let all visit the severely sick amongst the many at their own place,

Let members who fail to visit within ten days deliver them medicine and rice instead

And 1 sheng of grains. If they fail to deliver these, the penalty is 1 dou.

One item: all members are to bid farewell to the deceased at the funeral. Amongst them,

Those who do not attend are penalised by 1 dan of coarse grains

One item: if a member brings a dispute or lawsuit to the bureaus,

Let there be a penalty of 1 dou of coarse grains. If this payment is not delivered,

Let an additional penalty of 5 dou of coarse grains be imposed.

One item: those who drift away from the gatherings are punished 1 dan of wheat

One item: to a member preparing a funeral for his deceased wife, deliver 1 dou of coarse

Grains. If this amount is not delivered, let there be a penalty of 3 dou of coarse grains.

One item: if the deceased member of the society had ? 2 dou of coarse grains

The extra is to be paid?? If overde, let there be a penalty of 1 dan of coarse grains. ${ }^{290}$

290 This line was added later, in a small font. The characters are blurred and almost illegible. 
One item: in preparation for a funeral, pay 2 sheng \& 3 rolls of rice and grains

If overdue or unpaid, let there be a penalty of 5 dou of coarse grains. One item: the society's gathering ...

One item: at the monthly gathering, deliver 1 sheng of rice/grains, 2 sheng of coarse grains

If not delivered, let there be a penalty of 5 dou of coarse grains; willing.

One item: gathered society one? no? nobody?? the absent ones are penalised by 5 dou

One item: when the society gathers to deliver merit-making ?? where amongst the many?

Those who resort to selling are subject to a penalty of 3 dou of coarse grains

One item: if two join the gathering not for substantial matters, or if they form a faction

The penalty is 5 dou of coarse grains

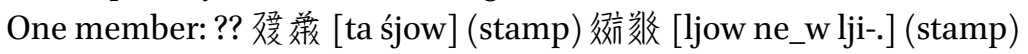

One member: 伤光 [pji-r tsji-] (stamp)? 嫹 [ta] (stamp)

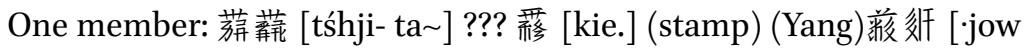
la śizj] (stamp)

One member: 捘 [pu.]?? 㭢 [gju_] (stamp) ${ }^{291}$ (Yang)恲 [da kia]? [?] (stamp)

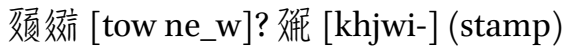

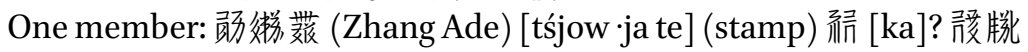
涤 [zji rjijr lji-.] (stamp)

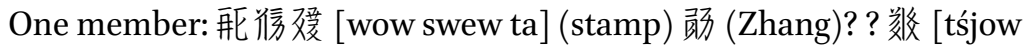
lji-.] (stamp)

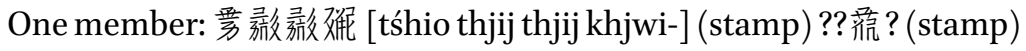

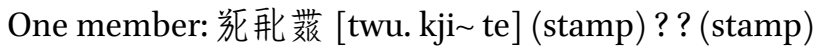

291 The name here is crossed out. 


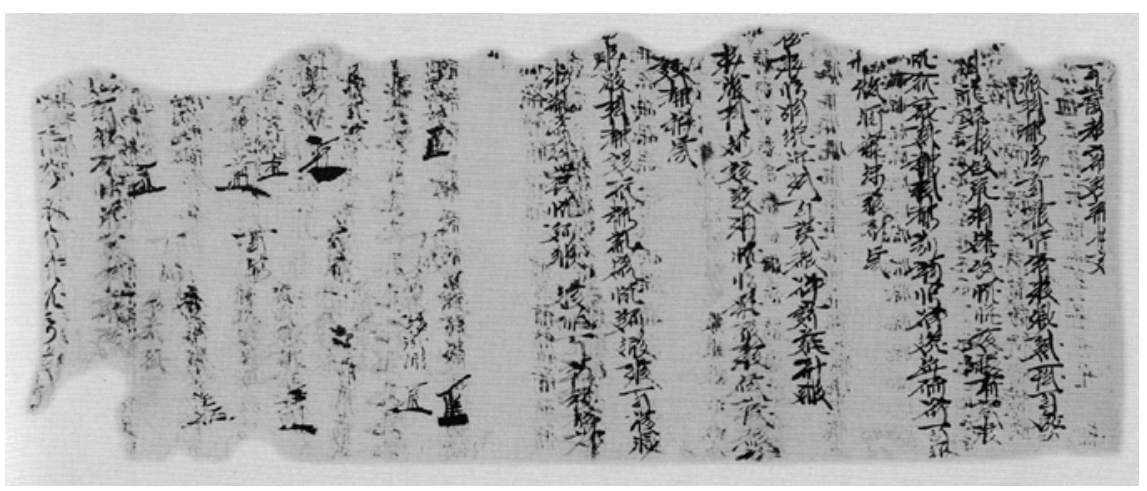

FIGURE 207 Инв. No. 7879: Communal contract

2. The Инв. No. 7879 Communal Contract is a $19 \mathrm{~cm} \times 48 \mathrm{~cm}$ fragment of 19 lines of cursive Tangut handwritten on a piece of hemp paper. ${ }^{292}$ Due to excessive damages, the little ink that remains, and overlapping writings on the front and the back of what used to be a sutra, which very much confuse the characters; lots of words remain unidentified. Therefore, only a rough transcription is provided in the notes. ${ }^{293}$

\footnotetext{
292 Russian Collection of Khara-Khoto Manuscripts, vol. 14, p. 198.

293 TN: Transcription into Chinese characters with notes:

... One dou of coarse grains ...

....? 甲中有身轉者有時尸置上一[泊]? ? (in case of a deceased member of the society) 令音唇以? 其日先如不來與二斗? (members who do not attend the event have to pay 2 dou)

不僅庫置中甲中三石布施上? $<>$ 施一?

? 憂四類? 小為當

一條聚日上? 處一斗雜施供養為緣因 (1 dou of contribution to be paid during the gathering)

一條顯甲會已置日不聚日過時五斗雜? (absence results in a penalty of 5 dou of coarse grains)

?? 繳當 (a certain amount to be paid)

一條顯甲中已人中大眾不議過時一??

日? 眾?? 不議因 官依一石麥繳服 (regardless of reasons, to pay 1 dan of wheat according to the law)

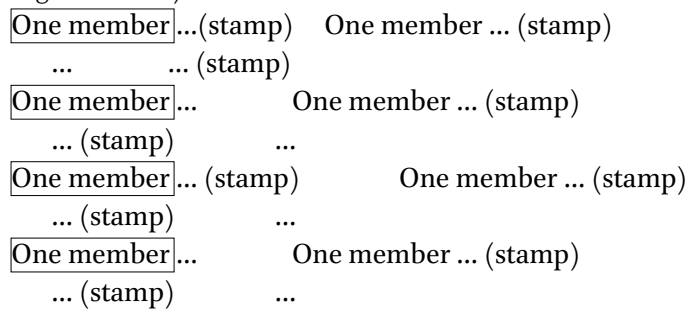




\subsection{2}

The Content of Communal Contracts

The two new Tangut charters set out the rules for collective activities that bind the members of the society, whereby participants commit to their solemn pledge of mutual support. The documents are written in the Tangut cursive script. The contract refers to the organisation as a 嬳纱 [-ji ljwu] (lit. the many, gather; i.e. the gathered many, an organised society). The document ends with the signatures and stamps. By virtue of this format and content, it acquires the legal force of a contract. For this and other reasons, these charters are considered to be communal contracts.

If the Dunhuang library cave furnishes us with a corpus of 1oth century medieval communal contracts, then these two Tangut documents fill in the void of the 12th century. The first one, in particular, is preserved almost in its entirety and in excellent conditions.

The No. 5949-31 Communal Contract in the Yin Year of Guangding is almost entirely legible, despite some loss of words near its end. This document suffices to inform us of the basic format and content of Tangut communal contracts. It is written in fluent Tangut on a white hemp paper. The text starts with an opening statement, and a detailed reference to time: "On the 15th day of the 11th month in the Yin Year of the Guangding era" (1218), followed by the characters 茫很, an expression that appears as many as 7 times in the document. The contract then enumerates 11 rules of the society, with two more additional stipulations that appear in a smaller font, making it 13 rules in total. There also seem to be some crossings and erasures. Each item of rule begins with the formulaic expression, 䊉服 [·ja tjij] (one item). The gathering activity of the society is referred to as 很槁 [ljwu dzji-.] (gather, assemble; to gather into an assembly), which appears 3 times in the text. The participants in these gatherings are called 㪤茫 [tha jii] (lit. large, many; the many, or the gathered many), which likewise appears 3 times. Finally, there are the signatures and stamps of the members. Due to the damages at the end of the manuscript, it is virtually impossible to know the precise number of members in this society.

This communal contract not only shares the generic features of the many contracts discussed in this chapter, but retains its own characteristics. Therefore, it is better understood as a special contract. As a charter of rules that govern the conduct and activities of a voluntary social organisation in Khara-Khoto, it surely differs from contracts of an economic nature, such as those of transactions, mortgages, loans, and leases, which serve to testify to a set of agreements by the two parties involved in an economic relationship. Rather, the communal contract binds multiple parties to a collective agreement, whereby all members give their consent and mutual reassurance. It is a 
form of regulation in the private social sphere, at a distance from the laws of the government.

The opening statement of the communal contract makes it clear that the members associate with the society voluntarily. They obviously agree to gather on the fifteenth day of each month. We know, therefore, that the society operates by monthly meetings. Moreover, the constituent members agree to abide by the following rules and regulations.

The first item of stipulation states that all members, except those who fall sick and those who embark on long-distance travelling, are obliged to attend the monthly gatherings on the fifteenth day of each month. Those who are absent without legitimate cause are to pay a penalty fee of grains in the amount of $5 \mathrm{dou}$. Although a private initiative unfettered by governmental regulations, the society obviously enforces its own rules rigorously. Once an individual joins the group, he faces coercive punishment from the organisation for failure to comply with his duties.

The details of the contract all point to the impression that the society is founded on the basis and for the sake of mutual support. According to the second rule, for example, all others are obliged to visit the heavily sick members of the group. Furthermore, "Let members who fail to visit within ten days deliver them medicine and rice instead and 1 sheng of grains. If they fail to deliver these, the penalty is 1 dou." And under the second rule, if a member passes away, his funeral is attended by the whole group. Those who do not show up have to pay "1 dan of coarse grains." According to item 6, when a member prepares a funeral for his deceased wife, others either support him with 1 dou of coarse grains, or face a penalty in the amount of 3 dou. Likewise, items 7 and 8 also concern spiritual and material support for the funerals of deceased individuals. Visitations by fellow members of the society is a source of consolation, and a positive force in the treatment and recovery processes. Moreover, attendance at the funeral is socially important, and more grains are always most helpful to the survived families. These and such social conducts are a kind of humanitarian support and mutual care. It promotes friendly and fraternal solidarity and communal love within the neighbourhood and across families and households. To some extent, it reflected the tenets of moral teachings and the prevalence of public mores at the time. Whereas it most cases, this layer of morality and sociability is optional, often undertaken by the virtuous and unattained by others, it is an enforceable obligation and procedural necessity for those involved in these organisational societies. Those who do not either live up to this aspiration or fail to comply with their duty face stringent punity in economic terms. 
A number of characters in item 4 remain undeciphered. But the undecoded part does not prevent us from understanding the basic meaning of the text. It states something to the effect that, a member implicated in a lawsuit, and possibly incriminated at the court, is also charged with a penalty fee of 1 dou of coarse grains. Those who do not comply are further charged with 5 dou of coarse grains. In this scheme of double punishment, members are warned not to violate any laws, lest they be both indicted by the government and punished within the society. Objectively, such a measure also reinforces the law and order under the local government. By a mixture of mores and laws, the society supports the political end, as well. Of course, morals and laws are products of their own time. And during this time, both the moral teaching and the legal regime are installed to defend the rights and interests of the powerful, a tool to safeguard and facilitate the smooth operation of the social sphere in its existing order. The Tangut Empire is ruled by its imperial law code. The government enforces these laws to perpetuate imperial rule by the royal elites. The laws are more effective when this regime is capable of normatively shaping the social conduct of its subjects. What is interesting here is that the communal society deters its members from violating the imperial laws by threatening them with the society's by-laws. The force of this deterrence comes from within the voluntarily-formed civil organisation. In this way, the civil is allied with the governmental, the private with the public, and the social with the imperial.

Item 10 in the Communal Contract requires that each member pay a due of 1 sheng of rice or grains, 2 sheng of coarse grains during the monthly gathering. Failure to do so would result in a penalty fee of 5 dou of coarse grains. Therefore, members are not supposed to join the meetings empty-handed.

The signatures and stamps at the end of the text suffice to show that the document is of a legal nature. It should therefore be considered as a proper contract. In the opening statement of the contract, there is no mention of a leader who acts as the legal representative of the society. But it is possible that the first name on the file counts as the head of the organisation. A quick glance at the calligraphic style reveals that the handwriting is consistent from the main text to each of the signatures. There is no doubt that the same person who drafted the document wrote down all the names, as well. But each name is followed by highly varied signs, prints, and stamps. The stamping endows the text with legal force.

The record of individuals who signed and stamped in the contract may not be the full list, given the damage of the contract near the end of the manuscript. What appear on the page now are 17 signatories and their stamps in 8 lines. A certain name was crossed out in line 4, and replaced by another name to its left, which is the 5 th line. In other cases, each line contains 2 names, one 
above and the other below. Further above the name in the upper section, there is a formulaic expression, 系彽 [lew ljwu] (lit. one, gathering; one member of the society in the gathering). These two characters are not repeated for the name below. This, again, testifies to the pragmatism of the format.

Another Communal Contract written in Tangut is the Инв. No. 7879 manuscript, which suffers excessive damages. The text is thus barely legible. Still, a bit of information could still be extracted from the modicum of words that lend themselves to a rough translation. In line 7 , the opening "One Item" is followed

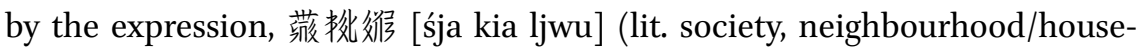
hold; gathering). In line 9, “One Item" is followed by 䓷糀. It is possible that the "Neighbourhood/Household Society" is the name of society concerned.

The contract also specifies that "on the day of the gathering, submit a due provision of 1 dou of coarse grains." Whereas in the No. 5949-31 Communal Contract mentioned above, each member pays 3 sheng of coarse grains during the monthly gathering. It seems that the dues are higher in the Инв. No. 7879 contract. Note that, as shown in the Инв. No. 7879 Communal Contract, failure to show up at the meeting results in a penalty of 5 dou of coarse grains, which is the same amount as the penalty fee for absence as specified in the No. 5949-31 Communal Contract.

\subsection{Communal Contracts and the Tangut Society}

Societies are popular communal groups that formed in the civil sphere, and at the base level of the Chinese society. Some societies wield considerable power and influence in the local area. Communal documents found in the Dunhuang cave library show that societies remained popular in and near Dunhuang from the Tang Dynasty and the Five Dynasties, down to the Song period. Building on this discovery, the corpus of Tangut communal contracts in Khara-Khoto show that communal societies also existed in Western Xia, even in the far-northern city of Khara-Khoto. The new manuscripts that come to light only in recent decades have added new primary materials to Tangut historiography, which enable scholars to dive into the socio-economic base of the Tangut Empire.

The Tangut and Dunhuang communal contracts belong to the same type of texts: charters that set down the rules and bylaws of an organisation. In Chinese historiography, documents referred to variously as Shetiao [社條], She'an [社案], or Tiaoliu [條流] are the basic texts of communal documents. The Dunhuang documents are varied in their lengths and details. Typically, a text begins with the general principles, narrates the purpose of founding such a society, the reasons for the establishment of the rules. It then proceeds to delineate the structure of the society and the substance of its activities, as well as terms and conditions of penalties that deter members from violating 
the rules. When the text sets out to account for the motifs and purpose of the society, it typically legitimates its raison d'être by the tenets of Confucianism or the doctrines of Buddhism. Under the spirito-ideological guidance of these principles, the society is said to enable friends to form partnerships for mutual support and education, for members to engage in collective sacrificial rituals and to offer aids in their own lives, and also to collaborate on fasts and funerals: there are usually two communal sacrifices, one in the spring and the other in the autumn, in addition to three long fasts. ${ }^{294}$ Rules are itemised, each in its own line. Each item starts with the formulaic expression, "One ..." which falls in line with the formats of legal writings during this period. Some other communal charters, however, do not itemise the rules. Subscribed members are called the 'many of the society,' or the 'society's many'. They participate in communal affairs under the watchful eyes of the 'head of a society,' 'officer of the society,' and the 'elder of the society' (also called the 'transcriber of the affairs'). These three roles are collectively referred to as the 'three officers', assigned by popular will. The society operates under the guidance and leadership of these communal 'officers.'

Both Tangut and Dunhuang Communal Contracts are charters of civil societies, voluntarily-formed for mutual help and support, in the private sphere of the medieval society. The Tangut contracts do not elaborate on the fundamental reasons for setting up the society in the first place. There are few, if any moral narratives that justify the establishment of the organisation, or the enactment of the by-laws. The contracts are straightforward about the clear and precise terms: what acts are permitted and what not, and what penalties ensue from the violations of these terms of agreement. In contrast, the Dunhuang documents feature more didactic narratives of moral reasoning. The British manuscript, the Dunhuang S 6537 (back)/3-5 "Charters of a Society founded by Fifteen Individuals" states the following:

It is heard that in the splendid realm of Dunhuang, the society rests upon the principles of the Three Gems. ${ }^{295}$ The customs and mores depend on the support of the wise and prudent ... The people live in peace and prosperity, where benevolence and righteousness prevail. No family is in want of reverence for the good order, ${ }^{296}$ and all neighbourhoods spread the

294 TN: The Three Fasts [三長齋月] refer to fasts in the first, fifth, and ninth months of the lunar calendar.

295 TN: Of course, the invocation of the "Three Gems" (三寶) is in the Buddhist sense of Pali: tiratana (Sanskrit: त्ररित्न/रत्नत्रय).

296 TN: The loose reference to the order of the more or less dignified and revered (尊卑) could be based on age, gender, and other familial patterns. So, I have refrained from rendering it as simply 'old and young' (長幼尊卑). 
teachings and rituals of filial piety. However, fearing that perchance, tensions may arise and harm, and that the good human sentiments may not persist as in times past; that in these scenarios, disagreements may ensue, and that each party clings onto its own partial view, the fifteen individuals here resolve to form a contract, with a shared mentality and understanding. The elders are to be treated with the same intimacy as parents, and to be provided for all the time. The younger are like loyal sons, and will never change their ways ... To help those in perils and to save the lives at stake; to benefit the dead and to honour those alive; to sacrifice oneself for the good of others, and never begrudge; all must deliberate and negotiate; let the hearts of men not change over the course of time. Because all are of the same opinion, we hereby establish this document as a testimony. We shall thus form a society of fraternal fellowship, which is to be remembered and respected by posterity. ${ }^{297}$

The Dunhuang manuscript Д11038 contains the charter of the Society of the Suowang clans. The document makes clear that,

The kins of the Suowang ... gradually evolve into divided households. The families have changed their wills in pursuit of their interests, and in so doing, neglected the customs of the good order. The elderly and the young cannot bear to see, and fear that their generation brings shame to the name of their ancestors. ${ }^{298}$

The Tangut communal contracts seem to have inherited the core features and purposes of Chinese equivalents: the defence of the basic social order of the feudal society, and the tradition of mutual help and support. But the Tangut documents significantly reduced the moral teachings. Without the didactic prolegomena, the Tangut texts are simpler and more practical.

With respect to the numbers of rules and items in the contracts, the rather complete Tangut communal contract, Инв. No. 5949-31 in the Yin Year of Guangding contains 13 items. Fewer items have survived in the Dunhuang contracts. For example, due to damages, only two of the additional rules laid down by the head of the society Wang Wu et al. have survived in the P.3544 manuscript, dated to the 29th day of the 9th month, in the 9th year of Dazhong (855 AD); Seven items have survived from the S.2041 manuscript, the charter of the society for the western alley in the 'neighbourhood of Confucian mores,' thrice renewed in the Dazhong era (847-860 AD); the charter of a certain

297 Ning and Hao, 1997, pp. 49-5o.

298 Mie Xiaohong, 2008. 
Dunhuang-based society, found in the P.3989 mansucript dated to the 1oth day of the 5th month in the Third Year of Jingfu (894), does not enumerate its by-laws in a list of separate items; Even the content-rich charter of the society founded by fifteen men - the sample that has been analysed in the S 6537 (back)/3-5 manuscript, only 7 items survive. ${ }^{299}$ A quick survey of the Dunhuang corpus shows that none of its communal contract is as elaborate as the Tangut communal contracts.

The communal societies as evidenced in the Dunhuang contracts are diverse in their natures and purposes. Some set their goals as mutual economic help and provision for common livelihood. Others are organised around the Buddhist rituals and worshipping activities. The two identified pieces of Tangut communal contracts both belong to the tradition of mutual economic support. Below are the four main functions of the society:

(a) Periodical gatherings, in this case on a monthly basis. These gatherings are supposed to build personal connections and emotional ties within the society, so that the participating families stay engaged and informed on the situations at other households.

(b) The society pledges spiritual and emotional support to its members in vulnerable positions and under difficult circumstances. Members are obliged to pay visits to the sick and the dead, to show care and pay condolences. Such items suggest that Tangut societies aim not only at the betterment of material conditions but also the promotion of mental, spiritual, and emotional welfare.

(c) But the society is also pragmatic in its approach to support its members. Death of a family member comes with pain but also a significant cost. A funeral always places a heavy financial burden on the survived. So, the provision of foodstuff is a matter of both spiritual and financial support and solidarity. As the communal contract No. 5949-31 in the year of Yin of Guangding shows, a member who suffers the death of a wife claims at least 1 dan 7 dou of coarse grains from the society. In the case that the member himself passes away; the family is to receive 3 dan 4 dou of coarse grains.

(d) Members of the society are punished for any conduct in violation of its by-laws. The penalty usually comes in the form of the confiscation of grains. This punitive measure has three ends: to warn and deter members, both the ones guilty and those who are not, from violating the rules in the future; to increase the stockpile of grains; and to establish the dignity and firmness of order in the civil sphere. The society acts as a

299 Ning and Hao, 1997, pp. 1-66. 
quasi-government when it enforces its principles by force. In this regard, these non-governmental organisations are a complementary force in concordance with the imperial government. They play a supporting role in guarding the rules and orders of the feudal society.

The materials above outline the basic structure of rights and obligations for those who form or join a communal society.

It is obvious from the Dunhuang communal contracts that the three communal 'officers' lead the societies into various activities, according to the rules laid down in the contract. Candidacies for the officers are proposed and approved by the members of the society. But it also occurs every so often that these positions come to be filled by large clans and powerful families in the area. Some societies are also controlled by the local governments, temples, aristocracies, bureaucracies, and wealthy households, who derive indirect levies and labours from the communities. But the two Tangut communal contracts contain no materials on these subjects, and therefore shed very little light on the possibility that such phenomena might also have been found in Western Xia.

The communal society stockpiles grains from monthly dues (3 sheng per member each month). For a society of 17 members, the sum is around 6 dan of grains for a fiscal year. As mentioned earlier, the society also accrues grains by means of penalty fees. As for whether these grains are owned by the legal persona of the society, or by the heads of the organisations, or yet, perhaps, owned collectively by all, is not articulated in any legal language. Therefore, there is no reason to exclude the possibility that the leaders of the society might have embezzled common properties.

But the stamps and signatures on the back of the communal contract point to a significant level of collective participation. The by-laws are put forth and signed into effect by all the members as a collective body. They are therefore obeyed, guarded, and accounted for by all the signatories. There is basic equality and collective liability in this arrangement. In this regard, the Tangut and Dunhuang communal contracts share more common ground. ${ }^{300}$

Amongst the identified names of the 17 undersigned in the communal contract Инв. No. 5949-31 in the Yin Year of Guangding, no typical Dangxiang Tangut clan-name has been identified. The Han names are the vast majority: 2 Yangs, 2 Zhangs, as well as Wang, Ge, Liang, as well as 1 Khitan. It is well

300 Meng, Xianshi. “Lun Tang Song Shiqi Dunhuang Minjian Jieshe de Shetiao” [論唐宋時 期敦煌民間結社的社條]: “On the Charters of Civil Societies in the Eras of Tang and Song” Ji, Xianlin and Jao, Tsung-I. Dunhuang Tulufan Yanjiu [敦煌吐魯番研究(第九 卷)]: Journal of the Dunhuang and Turfan Studies Volume IX. Zhonghua Book Company, May, 2006, pp. 317-337. 
possible that the communal enthusiasts who joined these societies were mainly comprised of Han Chinese, who might have held on to such a tradition. But given Khitan membership, it also seems as if societies in Western Xia broke ethnic barriers. Some of these communal societies might have been properly 'multi-ethnic.' At any rate, these founding documents of civil orgnaisations offer a new perspective on intra- and inter-people conducts in the private sphere, at a distance from the imperial authority. They add a new element of 'multi-ethnicity' to the historical study of communal contracts.

The Tanguts also resorted to crowd-funding to alleviate the plight of poverty. They undertook private initiatives to establish mutual funds for communal support. Such a manuscript that documents the terms of the mutual fund has been found. It is an account excavated in the cave of Xiaoxigou Hills, in Wuwei. The text translates as, "On the 7-5 day of the first month, in the Year of Tiger in Tianqing, [funds] are crowd-sourced at the place of Eming Quanbao. The funding sources are: Elao 'the lady' pledged 150 mace; Wamo Axinji 10o; Lingjie Xiaowuyu 150, Eming 'the treasured puppy' 50; Su 'the iron puppy' 50; Mingbu 'treasure of the little house' 5 ; Eliu 'the uncle's gold' 5 \%; Elao 'guided by the uncle' 5 \%; Wu 'treasure of the dog and the cow' 5 o; Eming 'the lady' $5^{\circ}$; total sum: 750 mace enters the communal account." 301

The Year of Tiger during the Tianqing era (1194) falls in the late period of Western Xia. The account shows but a modicum of funding. It reflects a particular perspective of mutual economic support in the private sphere of the Tangut society.

Features of Tangut Contracts

Amongst the vast number of Tangut social documents, especially those unearthed in Khara-Khoto, the contracts are undoubtedly the most eye-catching and thought-provoking sources. Tangut contracts are large in number and diverse in kinds. Each type of contract is known for its own characteristics.

Tangut contracts are largely similar in format. A contract sets about the transaction with its time, then the names of the Contract Parties, followed by the content of the contract. In most cases, the document includes a clause on potential disputes with relatives and neighbours, and the terms of default and penalty. At the end, the contract is sanctioned and notarised by the signatures

301 Shi, Jinbo. “Gansu Wuwei Faxian de Xixiawen Kaoshi Zhiyi” [甘肅武威發現的西夏文考 釋質疑]: “Questions over the paper, 'Critical interpretation of the Tangut texts found in Wuwei, Gansu” Kaogu [考古]: Archaeology, issue 3, 1974. 


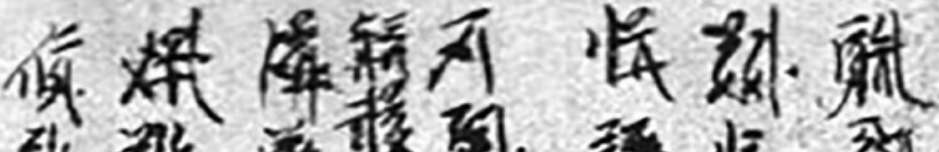

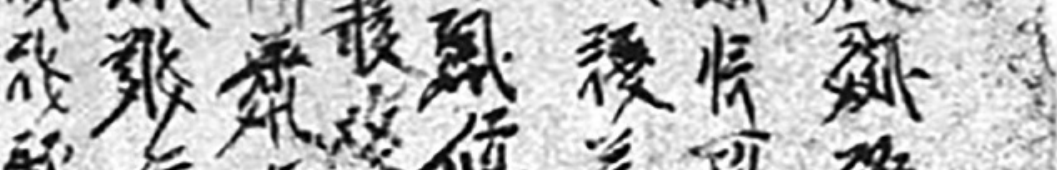

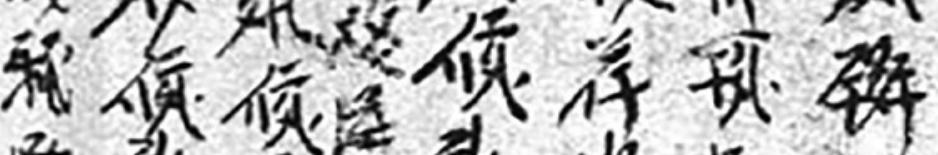

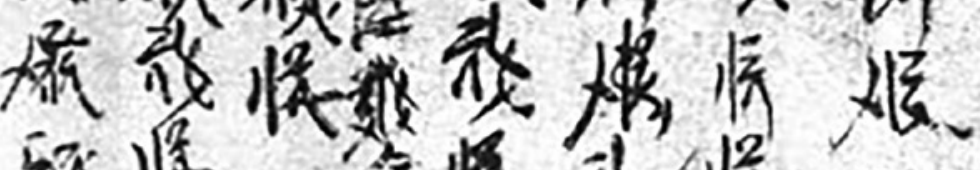

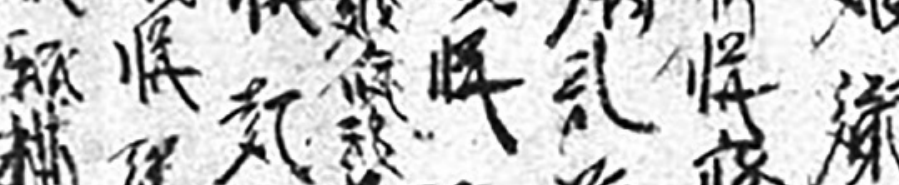

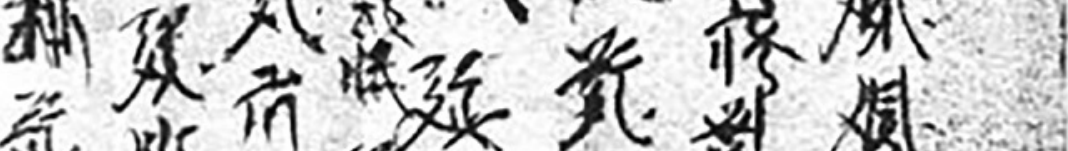

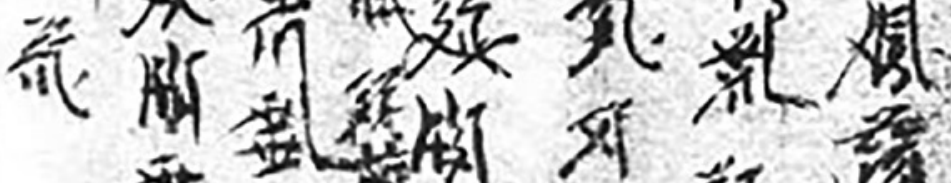

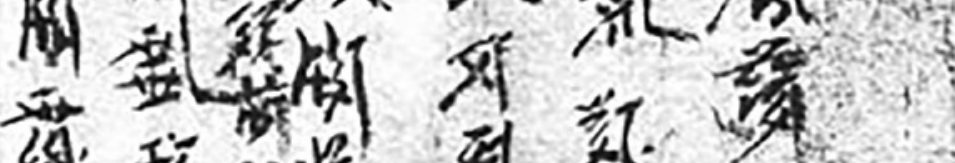
\&! ix 告, of if

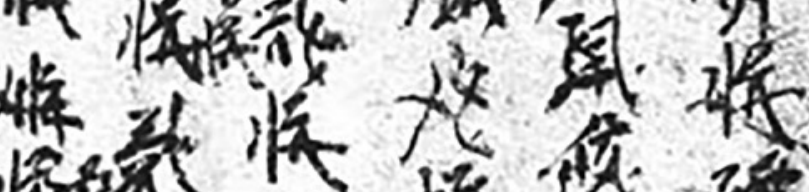

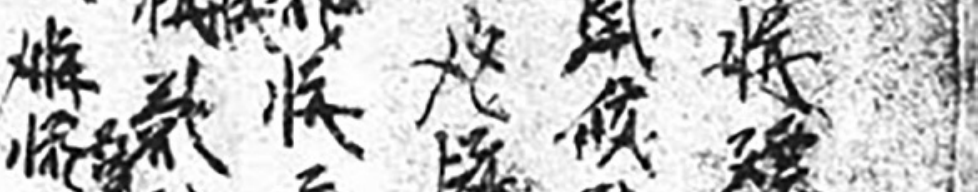

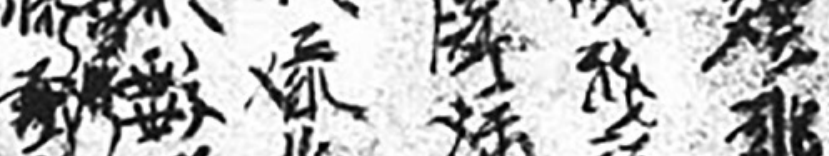

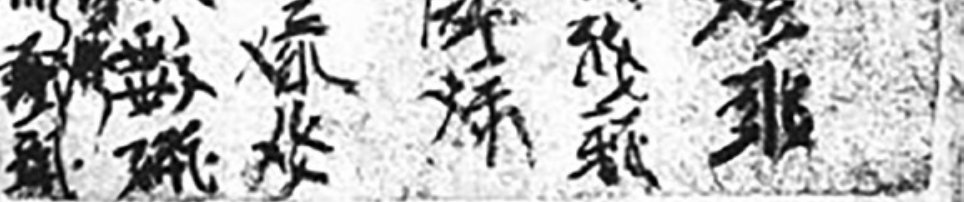


and stamps of the concerned parties and the witnesses. Tangut contracts do not narrate the causes and reasons for the transaction, as is the tradition of contracts in previous dynasties. The format is largely formulaic and formalistic. The fact that all Contract Parties follow the same legal formula speaks to the maturation of the contract as a legal genre in Western Xia.

Contracts in Western Xia also inherit certain traditions of contracts from Han Chinese practices. These similarities are also shared by the Dunhuang contracts. Although written in the Tangut language, the spirit of the contract reflects a long-standing tradition in the Chinese legal history of contracts.

The rich variety of Tangut contracts showcases the very diversity of the Tangut economic lives.

Grain loan contracts are signed most often in the intervening times between two harvests. These contracts testify to the historical practice of usurious loans, whereby the interest rate reaches as much as $50 \%$, and even $80 \%, 100 \%$ and beyond. These primary materials reveal the heavily exploited lives of the Tangut poor who suffered at the hands of loan sharks. The presence of not only numbers written in characters but also numerical notations speaks to the influence of mathematics in the Central Plains on accounting practices in Western Xia.

A large number of land sales contracts are signed by impoverished Tangut peasants who sold their farmland in exchange for subsistence. Buyers included temples and landlords, who expanded their large possessions of land into farmlands, encroaching upon private lands by a series of acquisitions. To generalise, these economic phenomena take place characteristically towards the end of dynastic empires throughout the long imperial history of China. Such is the case in the land sales contracts of Western Xia. For historians, the contracts contain an enormous amount of data and information on the ownership, management, and transaction of public and private Tangut lands, that have hitherto been unknown to the world. Some contracts also inform us of the boundaries and delineations of land, as well as the locations and distributions of canals for irrigation purposes. The land marked as sold in these transactions sometimes include the abodes of the peasants, which speaks to the historico-anthropologico-ethnographical fact that the Tanguts in Khara-Khoto erected their dwelling places right on their farmland. Rich information with regard to water supply and locations of canals amplifies the historian's understanding of the use of irrigation in Tangut agriculture. For the first time, these contracts reveal to us the price of farmland in Western Xia. It is no overstatement to say that the price of land is critical to any meaningful study of the Tangut economy. Last but not least, the picture of Tangut labour, once entirely invested in hunting and pasturing, and now deeply engaged with agricultural 
production, reveals the significant extent to which inter-ethnic exchange and migration altered the structure of industries and shifted the modes of production in the progress of time.

Thanks to the Tangut land lease contracts, we are now aware of the surprising extent of land scarcity in Khara-Khoto, a city whose population was not at all dense, and where arable land was far from exiguous. The fact that so many Tanguts struggled to procure farmlands by lease, shows that the peasants must have lost their initial allotment of land to the temples and wealthy financiers. As a result, they are left with no recourse other than to rent back their sold land. The religious establishments of the temples, by a feat of 'asset manipulation' if not 'asset management,' are able to earn back the principle by the lease of a mere two years. That suffices to show how much rent they charged, and how serious a problem these land-monopolists pose to the local community.

An analysis of the livestock sales contracts uncovers the market prices of large livestocks in Western Xia: camels, cattles, and horses, amongst others. Needless to say, the prices of major commodities that are also factors of production in Western Xia are a key route to understanding the Tangut economy. A comparative study of livestock sales by grains and by cash, in Khara-Khoto and in Wuwei, respectively, arrives at the conclusion that the circulation of currency is much more developed in Wuwei than in Khara-Khoto. These contracts of livestock sales also provide us with a vivid testimony to the skyrocketing market prices of livestock in the late imperial era of Western Xia. The high inflation rate is probably due to social instabilities at the gloomy prospect of Mongol invasion.

Contracts of human sales and purchases have filled in the void of our understanding of human transactions in 12th-13th century China. The humans circulated as properties in these contracts are labelled as shijun or nupu, the semi-slaves of the lowest status in Western Xia. It shows that historically, there was at least a class of the 'enslavable' regularly sold and bought without complete authority over their own free dominion. Correspondingly, there existed a class of shijun-buying, and nupu-owning class of masters. This would have meant that Western Xia is a 'feudal society with remnant Slavery characteristics.' The contracts also reveal the falling price of humans towards the end of the imperial era. It is most likely due to social instability and external threats in the last two decades that the market of human transactions spiraled down, before an eventual collapse.

The Contract of Labour Employment analysed in this chapter is the only known example of labour employment contract dated to the 11th-13th centuries. It inherits the generally accepted format of labour contract in the Chinese tradition. But on top of it, the Tanguts simplified the content and the format. 
The moral persons of the employers and the employed in the legal document seem to exhibit the relationship of the dominus and the subordinate. The employees are required of intense labour, and yet offered a low wage. These and such arrangements reflect the social instabilities of the late imperial period, where means of livelihood was so strained that the few employment providers were able to exploit labour to such degrees of magnitude. The Contract of Livestock Employments, on the other hand, shows how the Tangut poor sell their livestock to the temples under the pressure of sustenance, then immediately rent back their sold animals from the wealthy. The temples acquire livestock at low prices from needy sellers, and then loan the animals back to their former owners at exorbitant prices. This exploitative investment strategy is highly profitable. But it further solidifies a vicious circle, setting the Tanguts already in financial troubles onto the road of perpetual impoverishment. As a result, the poor become poorer.

Contracts of livestock exchange constitute a rather rare genre of contracts amongst the known contracts of ancient times. The genre itself reflects the realities of voluntary economic exchanges of animal labour in the private sphere of the local populace. The end is to make flexible adjustments through temporary and complementary transfers of livestock as a factor of production, for the purpose of mutual benefits and interests. It is also worth pointing out that the grain loan contracts on livestock mortgage differ from simple grain loan accounts. Tangut borrowers resorted to mortgaging their livestock or other properties of equal value, in order to strengthen their case in taking out the loan, and to secure and guarantee the interest of the creditor, who expects to recover the principle and the interest by the due date of the loan.

The two pieces of Tangut communal contracts are a key finding after the discovery of the Dunhuang communal contracts. They fill in the void of communal contracts in the 12th century. Records of communal lives are a key source to historians who try to shed new light on the economic lives at the base level of the Tangut society. By these communal contracts, the Tanguts sought to set the terms for mutual help in their quotidian lives and activities. They are well in line with the tradition of communal contracts in the Central Plains, where local communities seek modes of cooperation in the private realm, in a way that complements, rather than undermines the feudal socio-legal order. Given this particular purpose, communal contracts tend to be simple and utilitarian in nature, without going too much into the tedious narratives of ethical norms and principles of constant virtues. Most participants in the communal contracts are Han Chinese, also in line with the customary practice of forming societies popular in Han Chinese communities. There are, however, a few Khitans in these civil societies. The presence of Khitan names shows that at 
least some neighbourhood communities in Western Xia could be properly described as 'multi-ethnic.' Such societies would to various degrees of visibility promote inter-ethnic exchanges and fusions in the Tangut Empire.

The form and content of Tangut contracts also vary according to the importance of the document and the transactions specified therein. It is usually the case, for example, that the more important the content is, the lengthier the text tends to be. The more valuable the property concerned is, the more detailed and convoluted the clause on disputes with neighbours and relatives seems to be. If the property isn't all that valuable, it is even possible to omit this bit of information. The penalty fee also varies: the greater the pawn or loan is, the higher the fee is. Likewise, the more there is at stake, the more complicated formalities such as signatures and stamps are. And the more signatories there are, the more formal the stamping format is bound to be. As a result, it often occurs that a quick glance at the outlook of contract suffices to judge its level of importance. A two-line document is probably a simple and straightforward loan record of a few dou or sheng of grains. Whereas, a contract featuring a dozen or so lines and a few hundred characters, as well as a long list of signatures and stamps, is probably the testimony of a much larger transaction.

The corpus of Tangut contracts is a multi-sector, multi-dimensional, and multi-perspective reflection on the history of the Tangut economy and the economic lives in Western Xia. As invaluable primary sources on Western Xia, the contracts realistically restore the many aspects of the Tangut society. It is a matter of fortune for Tangut history and a gift for all time that the Tangut contracts have survived to see the light of our own day. 